\title{
JOSUÉ DE MORAES
}

\section{Efeito in vitro de extratos e compostos naturais em Schistosoma mansoni}

Tese apresentada ao Programa de PósGraduação Interunidades em Biotecnologia USP/Instituto Butantan/IPT, para obtenção do Título de Doutor em Biotecnologia. 


\section{JOSUÉ DE MORAES}

\section{Efeito in vitro de extratos e compostos naturais em Schistosoma mansoni}

Tese apresentada ao Programa de PósGraduação Interunidades em Biotecnologia USP/Instituto Butantan/IPT, para obtenção do Título de Doutor em Biotecnologia.

Área de concentração: Biotecnologia

Orientadores: Profa. Dra. Eliana Nakano

Profa. Dra. Toshie Kawao

(in memorian) 
DADOS DE CATALOGAÇÃO NA PUBLICAÇÃO (CIP)

Serviço de Biblioteca e Informação Biomédica do

Instituto de Ciências Biomédicas da Universidade de São Paulo

(C) reprodução total

Moraes, Josué de.

Efeito in vitro de extratos e compostos naturais em Schistosoma

mansoni / Josué de Moraes. -- São Paulo, 2011.

Orientador: Eliana Nakano.

Tese (Doutorado) - Universidade de São Paulo. Instituto de Ciências Biomédicas. Programa de Pós-Graduação Interunidades em Biotecnologia USP/IPT/Instituto Butantan. Área de concentração: Biotecnologia. Linha de pesquisa: Pesquisa de substâncias naturais com atividade moluscicida e esquistossomicida.

Versão do título para o inglês: In vitro effect of extracts and natural compounds on Schistosoma mansoni

Descritores: 1. Schistosoma mansoni 2. Esquistossomose 3. Atividade esquistossomicida 4. Anti-helmíntico 5. In vitro

6. Compostos e extratos de plantas I. Nakano, Eliana

II. Universidade de São Paulo. Instituto de Ciências Biomédicas.

Programa de Pós-Graduação Interunidades em Biotecnologia USP/IPT/Instituto Butantan III. Título. 
UNIVERSIDADE DE SÃO PAULO

\section{Programa de Pós-Graduação Interunidades em Biotecnologia}

Universidade de São Paulo, Instituto Butantan, Instituto de Pesquisas Tecnológicas

Candidato(a): Josué de Moraes.

Título da Tese: $\quad$ Efeito in vitro de extratos e compostos naturais em Schistosoma mansoni.

Orientador(a): $\quad$ Eliana Nakano.

A Comissão Julgadora dos trabalhos de Defesa da Tese de Doutorado, em sessão pública realizada a .................., considerou

\section{( ) Aprovado(a) ( ) Reprovado(a)}

\begin{tabular}{|c|c|}
\hline Examinador(a): & Assinatura: \\
\hline & Nome: ......... \\
\hline & Instituição: ..................... \\
\hline Examinador(a): & Assinatura: ........... \\
\hline & Nome: ............... \\
\hline & Instituição: ........ \\
\hline Examinador(a): & Assinatura: ......... \\
\hline & Nome: .............. \\
\hline & Instituição: .................................................. \\
\hline Examinador(a): & Assinatura: ...... \\
\hline & Nome: ........... \\
\hline & Instituição: \\
\hline Presidente: & 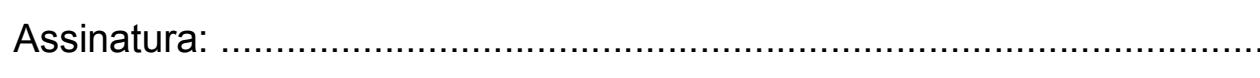 \\
\hline & 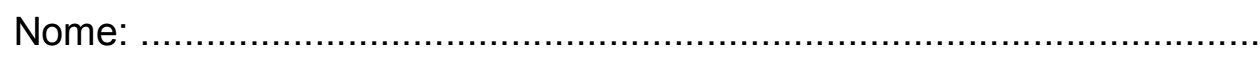 \\
\hline & 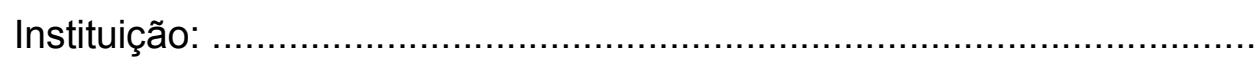 \\
\hline
\end{tabular}




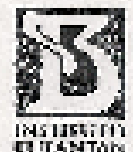

COMTSSAO 1U ITICA NOI RGO DE ANIMAR: INESIITUTO BTI'LWNAN

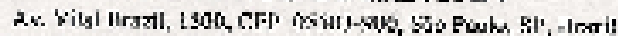

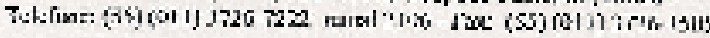

\section{CLRTTHCADO}

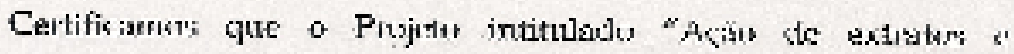

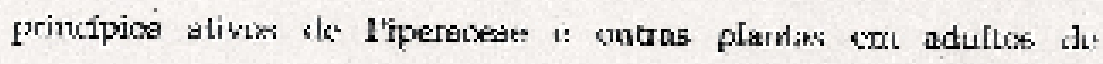

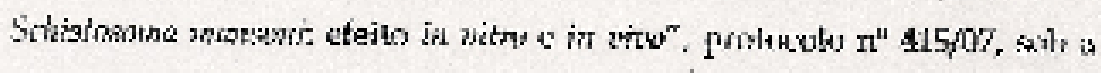

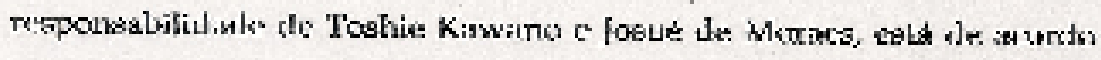

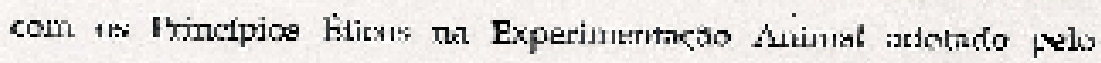

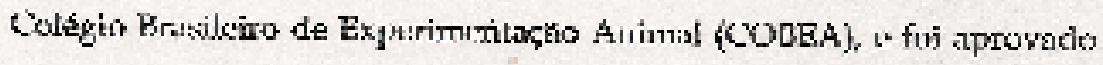

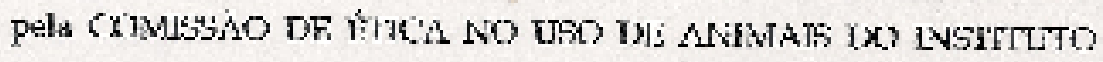

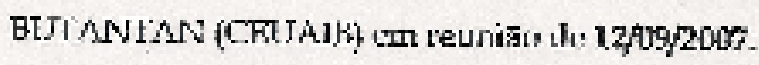

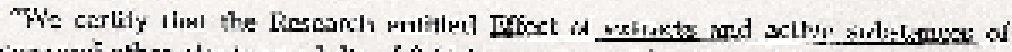

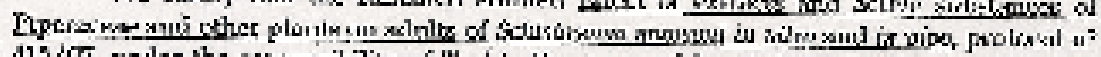

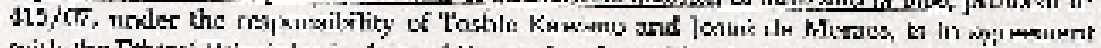

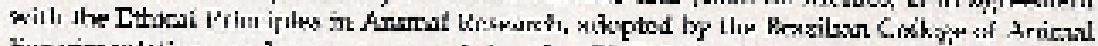

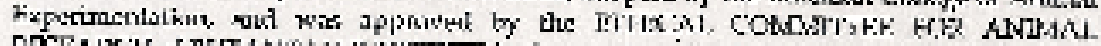

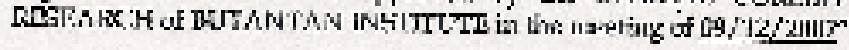

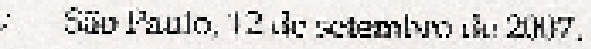

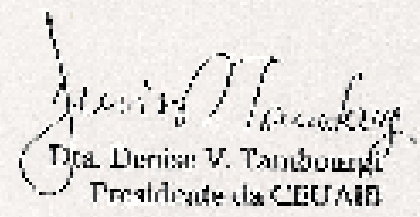

Dh: scontu:

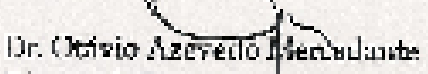

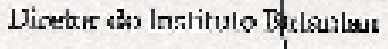


Aos meus pais Oscar e Dulce, que construíram a maravilhosa Família Moraes, e aos irmãos Jaide e Jairo. Agradeço a vocês pelo constante apoio e incentivo durante toda minha vida. 


\section{AGRADECIMENTOS}

À Profa. Dra. Toshie Kawano (in memorian), por ter me recebido no Laboratório de Parasitologia do Instituto Butantan. Tua amizade e valiosa orientação me ajudaram muito. Não tenho palavras para te agradecer, mas você sempre estará viva na minha vida profissional. Jamais esquecerei a última coisa que você me disse: "Josué, fique tranquilo. Eu confio em você".

À Profa. Dra. Eliana Nakano, pela amizade e orientação. Eu sei que foi muito difícil assumir essa tarefa após a perda da nossa mentora e amiga Toshie.

À Fundação de Amparo à Pesquisa do Estado de São Paulo (FAPESP), pelo apoio financeiro concedido ao laboratório.

À todos os estudantes do Laboratório de Parasitologia do Instituto Butantan que, direta ou indiretamente, contribuíram para a realização deste trabalho; em especial à Paty Aoki que me ensinou a técnica de perfusão.

Aos funcionários Alex, Arlete, Carlão, Cris, Lurdinha Canaleta e Juruba, pela amizade, convívio e contribuição durante todo o momento que precisei de ajuda. Eu ri muito com vocês. Arlete, perdi as contas dos favores que você me fez; não tenho como te pagar por isso. Alex, você me ajudou muito no microscópio confocal; seu nome sempre constará nos "agradecimentos" dos artigos pelas belas imagens que capturamos. Carlão, você não imagina o quanto foi importante sua contribuição para a manutenção do principal foco desta Tese: o Schistosoma mansoni.

Aos pesquisadores Dr. Lincoln Suesdek Rocha e Dra. Maria Carolina Elias, por compartilhar diversos materiais e equipamentos. E aos seus estudantes Fio, Paloma, Mariana, Camila, Dr. Eduardo e Ricardo Peruano, pela amizade e convívio no laboratório.

Aos colegas Dan, Orlando Bloom e Vanessa, pela amizade e convívio durante o período que vocês estavam no laboratório.

Ao Dr. Oswaldo A. Sant Anna, do Laboratório de Imunoquímica do Instituto Butantan, pelo apoio e orientação antes do credenciamento da Dra. Toshie Kawano.

Aos Profs. Drs. Pedro Ismael S. Júnior, Marisa Rangel e Dominique Corinne H. Fischer, pelas sugestões durante o Exame de Qualificação.

Ao Dr. Ronaldo Z. Mendonça, por gentilmente ter cedido as células utilizadas neste trabalho e pela contribuição nos ensaios de citotoxicidade. 
Ao Prof. Dr. Massuo Jorque Kato e à Dra. Lydia F. Yamagushi do Laboratório de Química de Produtos Naturais (IQ-USP), pelos extratos e compostos utilizados neste trabalho.

Ao Prof. Dr. José Roberto S. A. Leite e toda sua equipe que faz parte do Núcleo de Pesquisa em Biodiversidade e Biotecnologia (BIOTEC-UFPI), especialmente à doutoranda Leiz Veras Miura e ao David Lima da indústria Vegeflora, pela valiosa colaboração.

Ao Dr. Alan Wilson (University of York, York, Inglaterra), pelas discussões sobre a metodologia dos ensaios e pelas fascinantes explicações sobre a biologia de $S$. mansoni.

À Dra. Jennifer Keiser (Swiss Tropical Institute, Basel, Suíça), pelas valiosas sugestões que serviram para melhorar meus artigos.

Ao Dr. Kendi Okuda (Department of Medicine, University of Massachusetts Medical School, EUA), pela discussão dos meus resultados, além do inestimável auxílio com a língua inglesa.

À profa. Dra. Silmara Marques Allegretti, pelas discussões em algumas partes da metodologia deste trabalho.

Aos revisores (anônimos) que avaliaram os meus artigos submetidos. Aprendi muito como autor correspondente.

À Dra. Luciana C. C. Leite e aos colegas Henrique, Léo, Omar e Alex do Laboratório de Biotecnologia Molecular IV (Instituto Butantan), por compartilhar materiais e equipamentos, além das discussões sobre a biologia do $S$. mansoni.

Aos colegas de trabalho na Supervisão de Vigilância em Saúde (SUVIS Casa Verde), especialmente a Karla, Marcos Bolota, Marcelo, Sérgio, Nice, Wagner e Angélica que entenderam minhas ausências.

Às Faculdades Integradas Torricelli (FIT), pelo incentivo e liberação para que eu participasse de diversos eventos científicos. Nesta instituição, conheci muitos professores que hoje são grandes amigos.

Aos estudantes que orientei em Trabalho de Conclusão de Curso ou Iniciação Científica. Aprendi muito com vocês. Nossas pesquisas já resultaram, até o momento, em 3 artigos. 
Aos amigos que cresci e convive, pela amizade e incentivo. Um agradecimento especial ao Dimas, pela ajuda na impressão deste trabalho e reprodução de inúmeras cópias de artigos científicos.

Aos parentes das famílias Moraes e Correia que acreditaram no meu trabalho, pelo incentivo.

A toda minha bela família: aos meus pais Oscar e Dulce, aos meus irmãos Jaide e Jairo e ao irmão Jaime (in memorian), que eu não conheci, mas nunca esqueci seu nome. A família aumentou e, portanto, não posso deixar de citar o cunhado Rubens, a cunhada Néia e a minha belíssima sobrinha (e futura farmacêutica) Tamíris. Vocês sempre me incentivaram.

Finalmente, à Aline por todo carinho e compreensão; por sempre ter acompanhado e respeitado minhas decisões e minha ausência. Você será uma excelente farmacêutica e certamente aproveitarei seu potencial. 
"Mais do que máquinas, precisamos de humanidade. Mais do que inteligência, precisamos de afeição e doçura. Sem essas virtudes, a vida será de violência e tudo será perdido." 
"A melhor maneira que o homem dispõe para se aperfeiçoar, é aproximar-se de Deus."

Pitágoras 


\section{RESUMO}

MORAES, J. Efeito in vitro de extratos e compostos naturais em Schistosoma mansoni. 2011. 236 f. Tese (Doutorado em Biotecnologia) - Instituto de Ciências Biomédicas, Universidade de São Paulo, São Paulo, 2011.

A esquistossomose é uma doença parasitária de grande impacto social, sendo considerada um importante problema de saúde pública em mais de 70 países. Atualmente, o tratamento quimioterápico dessa parasitose é baseado no uso de apenas um fármaco, praziquantel, mas seu uso extensivo e inapropriado culminou no aparecimento de resistência. Dessa forma, é premente a necessidade de novas alternativas terapêuticas, especialmente com o uso de produtos naturais. No presente estudo, avaliou-se o efeito in vitro de 4 compostos isolados de espécies vegetais, as amidas piplartina e piperina, a lignana grandisina e o alcaloide epiisopiloturina; 1 composto isolado da pele de anfíbio, o peptídeo antimicrobiano dermaseptina 01 ; e de 6 extratos etanólicos obtidos de vegetais, Piper tuberculatum, $P$. crassinervium, $P$. diospyrifolium, P. fuligineum, P. gaudichaudianum e Pothomorphe umbellata em adultos (machos e fêmeas com 49 dias) e esquistossômulos (recém-transformados, 1, 3, 5 e 7 dias) de Schistosoma mansoni linhagem $\mathrm{BH}$. O estudo in vitro, em vermes adultos e esquistossômulos, da atividade dos compostos e extratos avaliou: 1) a viabilidade de vermes adultos; 2) a capacidade reprodutiva, avaliada pelo acasalamento e oviposição; 3) o efeito no tegumento em parasitas adultos; 4) a viabilidade e o efeito no tegumento em esquistossômulos. Além disso, a citotoxicidade de compostos e extratos em células de mamífero (célula Vero) também foi avaliada. Os resultados deste estudo mostraram que os compostos e extratos reduziram a motilidade e causaram a morte dos parasitas com alterações morfológicas no tegumento, cujos efeitos foram diretamente dependentes da concentração, do tempo de incubação e da idade dos helmintos. Nas concentrações subletais notou-se, ainda, redução na oviposição. Os ensaios in vitro revelaram que todos os compostos e extratos apresentaram ação letal aos esquistossomos sem afetar a viabilidade das células de mamífero. No geral, os esquistossômulos e adultos de $S$. mansoni foram mais susceptíveis a piplartina, dermaseptina e a todos os extratos etanólicos. Pela contagem dos tubérculos em uma área da região dorsal dos helmintos machos, usando microscopia confocal, neste estudo também é apresentado um novo modelo experimental que avalia, quantitativamente, o efeito de compostos e/ou extratos no tegumento dos esquistossomos.

Palavras-chave: Schistosoma mansoni. Esquistossomose. Atividade esquistossomicida. Anti-helmíntico. In vitro. Composto e extrato de plantas. 


\begin{abstract}
MORAES, J. In vitro effect of extracts and natural compounds on Schistosoma mansoni. 2011. 236 p. Ph. D. Thesis (Biotechnology) - Instituto de Ciências Biomédicas, Universidade de São Paulo, São Paulo, 2011.
\end{abstract}

Schistosomiasis is a parasitic disease of great social impact, and it is considered an important public health problem in over 70 countries. Currently, chemotherapy treatment for this disease is based on only one drug, praziquantel, but its extensive and inappropriate use culminated the emergence of resistance. Thus, there is a need to develop new antischistosomal compounds, particularly with the use of natural products. In this study, the in vitro effect of 4 compounds isolated from plant species, amides piplartine and piperine, the lignin grandisin and alkaloid epiisopiloturine; 1 compound isolated from amphibian skin, the antimicrobial peptide dermaseptin 01 ; and 6 ethanolic extracts of plants, Piper tuberculatum, P. crassinervium, P. diospyrifolium, P. fuligineum, $P$. gaudichaudianum and Pothomorphe umbellata was evaluated in adults worm pairs (49-day-old) and schistosomula (newly-transformed, 1-, 3-, 5-, and 7-day-old) of Schistosoma mansoni $\mathrm{BH}$ strain. The effect of compounds and extracts against schistosomes was examined regarding: 1) adult worms survival, 2) the reproductive fitness as assessed by mating and oviposition; 3) alterations on adult worms tegumental surface, and 4) viability and morphological alterations on schistosomula. Furthermore, the cytotoxicity of compounds and extracts in mammalian cells (Vero cells) was also evaluated. Results show that all compounds and extracts reduced the motor activity of worms, caused their death, and induced morphological changes on the tegument. All these effects were dependent on concentration, incubation time and age of helminths. At sublethal concentrations, extracts and compounds inhibited egg laying. The cytotoxicity was not detected in Vero cells after treatment with natural products. In general, adults and schistosomula of $S$. mansoni were more susceptible to piplartine, dermaseptin and all the ethanolic extracts. Morphological alterations on male worms were performed using confocal microscopy analysis by counting of the numbers of tubercles. In addition, this study shows a new experimental model to evaluate quantitatively the effect of compounds and/or extracts on the tegument of the schistosomes.

Key words: Schistosoma mansoni. Schistosomiasis. Schistosomicidal activity. Antihelminthic. In vitro. Compound and plant extracts. 


\section{LISTA DE ABREVIATURAS}

AFA - solução contendo ácido acético, formaldeído e álcool

ATCC - "American Type Culture Collection"

CVE - Centro de Vigilância Epidemiológica, Secretaria de Estado da Saúde de São Paulo

DMSO - dimetilsulfóxido

DMEM - meio de cultivo, Meio de Eagle Modificado por Dulbecco

DS - dermaseptina

HEPES - tampão [ácido N-(2-hidroxietil)piperazina-N'-(2-etanossulfônico)]

OMS - Organização Mundial da Saúde

PZQ - praziquantel

RPMI 1640 - meio de cultivo "Roswell Memorial Park Institute" 


\section{LISTA DE FIGURAS}

Figura 1. Distribuição global da esquistossomose

Figura 2. Distribuição da esquistossomose mansônica no Brasil, de acordo com o

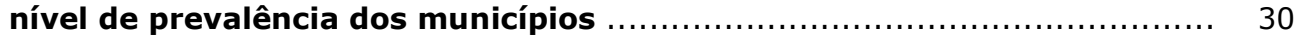

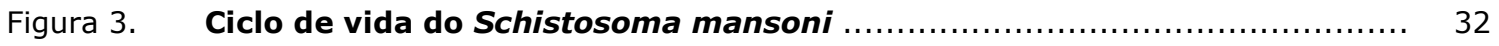

Figura 4. Área comumente associada à transmissão da esquistossomose ............ 34

Figura 5. Estrutura química das moléculas e sequência primária do peptídeo

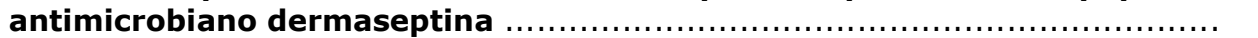

Figura 6. Região dorsal de um macho de Schistosoma mansoni, onde é avaliado, quantitativamente, o efeito de compostos e extratos sobre o tegumento 55

Figura 7. Efeito da amida piplartina na sobrevivência de adultos de Schistosoma mansoni

Figura 8. Efeito do peptídeo dermaseptina na sobrevivência de adultos de Schistosoma mansoni

Figura 9. Efeito do alcaloide epiisopiloturina na sobrevivência de adultos de Schistosoma mansoni .....

Figura 10. Efeito da amida piperina na sobrevivência de adultos de Schistosoma mansoni

Figura 11. Efeito da lignana grandisina na sobrevivência de adultos de Schistosoma mansoni

Figura 12. Efeito do extrato de Piper tuberculatum na sobrevivência de adultos de Schistosoma mansoni .....

Figura 13. Efeito do extrato de Piper crassinervium na sobrevivência de adultos de Schistosoma mansoni .....

Figura 14. Efeito do extrato de Piper diospyrifolium na sobrevivência de adultos de Schistosoma mansoni

Figura 15. Efeito do extrato de Piper fuligineum na sobrevivência de adultos de Schistosoma mansoni

Figura 16. Efeito do extrato de Piper gaudichaudianum na sobrevivência de adultos de Schistosoma mansoni .

Figura 17. Efeito do extrato de Pothomorphe umbellata na sobrevivência de adultos de Schistosoma mansoni .

Figura 18. Efeito da amida piplartina no tegumento de macho de Schistosoma mansoni

Figura 19. Efeito do peptídeo dermaseptina 01 no tegumento de macho de Schistosoma mansoni .

Figura 20. Efeito do alcaloide epiisopiloturina no tegumento de macho de Schistosoma mansoni ....

Figura 21. Efeito da amida piperina no tegumento de macho de Schistosoma mansoni 
Figura 22. Efeito da lignana grandisina no tegumento de macho de Schistosoma mansoni

Figura 23. Efeito do extrato de Piper tuberculatum no tegumento de machos de Schistosoma mansoni

Figura 24. Efeito do extrato de Piper crassinervium no tegumento de machos de Schistosoma mansoni ....

Figura 25. Efeito do extrato de Piper diospyrifolium no tegumento de machos de Schistosoma mansoni ....

Figura 26. Efeito do extrato de Piper fuligineum no tegumento de machos de Schistosoma mansoni

Figura 27. Efeito do extrato de Piper gaudichaudianum no tegumento de machos de Schistosoma mansoni

Figura 28. Efeito do extrato de Pothomorphe umbellata no tegumento de machos de Schistosoma mansoni

Figura 29. Efeito da amida piplartina nas ventosas de machos de Schistosoma mansoni

Figura 30. Efeito de compostos nos tubérculos de machos de Schistosoma mansoni . 112

Figura 31. Efeito de extratos vegetais nos tubérculos de machos de Schistosoma mansoni

Figura 32. Efeito de compostos na oviposição de Schistosoma mansoni

Figura 33. Efeito de extratos de plantas na oviposição de Schistosoma mansoni .......

Figura 34. Efeito da piplartina, dermaseptina 01 e piperina nos esquistossômulos, recém transformados e sete dias de idade, de Schistosoma mansoni .......

Figura 35. Efeito da epiisopiloturina e grandisina nos esquistossômulos, recémtransformados e sete dias de idade, de Schistosoma mansoni

Figura 36. Efeito dos extratos de Piper tuberculatum, Piper crassinervium e Piper diospyrifolium nos esquistossômulos, recém-transformados e sete dias de idade, de Schistosoma mansoni

Figura 37. Efeito dos extratos de Piper tuberculatum, Piper crassinervium e Piper diospyrifolium nos esquistossômulos, recém-transformados e sete dias de idade, de Schistosoma mansoni

Figura 38. Viabilidade da célula Vero em presença de praziquantel e piplartina

Figura 39. Viabilidade da célula Vero em presença de dermaseptina 01 e epiisopiloturina

Figura 40. Viabilidade da célula Vero em presença de piperina e grandisina ....

Figura 41. Viabilidade da célula Vero em presença de extratos de Piper tuberculatum e Piper crassinervium

Figura 42. Viabilidade da célula Vero em presença de extratos de Piper diospyrifolium e Piper fuligineum

Figura 43. Viabilidade da célula Vero em presença de extratos de Piper gaudichaudianum e Pothomorphe umbellata 


\section{LISTA DE TABELAS}

Tabela 1 - Compostos com características esquistossomicidas usados na terapêutica experimental ou clínica da esquistossomose ................. 39

Tabela 2 - Extratos ou compostos naturais com efeito esquistossomicida, in vitro, em Schistosoma mansoni

Tabela 3 -

Grupo químico e origem dos compostos selecionados para verificar o efeito in vitro em adultos e esquistossômulos de Schistosoma mansoni

Tabela 4 - $\quad$ Espécies vegetais e origem dos extratos selecionados para verificar o efeito in vitro em adultos e esquistossômulos de Schistosoma mansoni

Tabela 5 -

Composição do meio 169

Tabela 6 -

Concentração mínima de compostos e extratos capaz de causar efeito esquistossomicida em $\mathbf{1 0 0} \%$ dos adultos de Schistosoma mansoni ......

Tabela 7 - Efeito da amida piplartina na atividade motora e no acasalamento de adultos de Schistosoma mansoni

Tabela 8 - Efeito do peptídeo dermaseptina na atividade motora e no acasalamento de adultos de Schistosoma mansoni ...................... 76

Tabela 9 - Efeito do alcaloide epiisopiloturina na atividade motora e no acasalamento de adultos de Schistosoma mansoni $\ldots \ldots \ldots \ldots \ldots \ldots \ldots \ldots \ldots, 77$

Tabela 10 - Efeito da amida piperina na atividade motora e no acasalamento de adultos de Schistosoma mansoni

Tabela 11 - Efeito da lignana grandisina na atividade motora e no acasalamento de adultos de Schistosoma mansoni

Tabela 12 - Efeito do extrato de Piper tuberculatum na atividade motora e no acasalamento de adultos de Schistosoma mansoni

Tabela 13

Efeito do extrato de Piper crassinervium na atividade motora e no acasalamento de adultos de Schistosoma mansoni

Tabela 14 -

Efeito do extrato de Piper diospyrifolium na atividade motora e no acasalamento de adultos de Schistosoma mansoni

Tabela 15 -

Efeito do extrato de Piper fuligineum na atividade motora e no acasalamento de adultos de Schistosoma mansoni

Tabela 16 - Efeito do extrato de Piper gaudichaudianum na atividade motora e no acasalamento de adultos de Schistosoma mansoni

Tabela 17 - Efeito do extrato de Pothomorphe umbellata na atividade motora e no acasalamento de adultos de Schistosoma mansoni

Tabela 18 - Alterações tegumentares em adultos de Schistosoma mansoni durante incubação com a amida piplartina

Tabela 19 - Alterações tegumentares em adultos de Schistosoma mansoni durante incubação com o peptídeo dermaseptina 01

Tabela 20 - Alterações tegumentares em adultos de Schistosoma mansoni durante incubação com o alcaloide epiisopiloturina 
Tabela 21 - Alterações tegumentares em adultos de Schistosoma mansoni durante incubação com a amida piperina

Tabela 22 - $\quad$ Alterações tegumentares em adultos de Schistosoma mansoni durante incubação com a lignana grandisina

Tabela 23 - $\quad$ Alterações tegumentares em adultos de Schistosoma mansoni durante incubação com o extrato de Piper tuberberculatum

Tabela 24 - $\quad$ Alterações tegumentares em adultos de Schistosoma mansoni durante incubação com o extrato de Piper crassinervium

Tabela 25 - $\quad$ Alterações tegumentares em adultos de Schistosoma mansoni durante incubação com o extrato de Piper diospyrifolium

Tabela 26 - Alterações tegumentares em adultos de Schistosoma mansoni durante incubação com o extrato de Piper fuligineum

Tabela 27 - $\quad$ Alterações tegumentares em adultos de Schistosoma mansoni durante incubação com o extrato de Piper gaudichaudianum

Tabela 28

Alterações tegumentares em adultos de Schistosoma mansoni durante incubação com o extrato de Pothomorphe umbellata

Tabela 29

Redução do número de ovos de Schistosoma mansoni durante incubação com compostos e extratos vegetais

Tabela 30

Viabilidade de esquistossômulos de Schistosoma mansoni, com diferentes idades, em presença de praziquantel

Tabela 31 - Viabilidade de esquistossômulos de Schistosoma mansoni, com diferentes idades, em presença da amida piplartina

Tabela 32 - Viabilidade de esquistossômulos de Schistosoma mansoni, com diferentes idades, em presença do peptídeo dermaseptina 01

Tabela 33 - Viabilidade de esquistossômulos de Schistosoma mansoni, com diferentes idades, em presença de epiisopiloturina

Tabela 34 - Viabilidade de esquistossômulos de Schistosoma mansoni, com diferentes idades, em presença da amida piperina

Tabela 35 - Viabilidade de esquistossômulos de Schistosoma mansoni, com diferentes idades, em presença da lignana grandisina ....

Tabela 36 - Viabilidade de esquistossômulos de Schistosoma mansoni, com diferentes idades, em presença do extrato de Piper tuberculatum .......

Tabela 37 - Viabilidade de esquistossômulos de Schistosoma mansoni, com diferentes idades, em presença do extrato de Piper crassinervium ......

Tabela 38 - Viabilidade de esquistossômulos de Schistosoma mansoni, com diferentes idades, em presença do extrato de Piper diospyrifolium ......

Tabela 39 - Viabilidade de esquistossômulos de Schistosoma mansoni, com diferentes idades, em presença do extrato de Piper fuligineum ...........

Tabela 40 - Viabilidade de esquistossômulos de Schistosoma mansoni, com diferentes idades, em presença do extrato de Piper gaudichaudianum .

Tabela 41 - Viabilidade de esquistossômulos de Schistosoma mansoni, com diferentes idades, em presença do extrato de Pothomorphe umbellata 
Tabela 42 - Concentração mínima de compostos e extratos capaz de causar efeito esquistossomicida em $\mathbf{1 0 0 \%}$ dos esquistossômulos de Schistosoma mansoni

Tabela 43 - Concentração mínima de compostos e extratos capaz de causar efeito esquistossomicida em todos os esquistossômulos (recémtransformados e 7 dias de idade) e adultos (machos e fêmeas, com 49 dias) de Schistosoma mansoni 


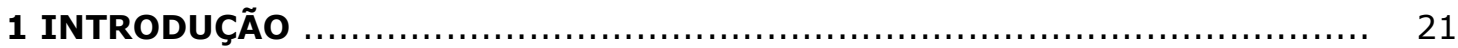

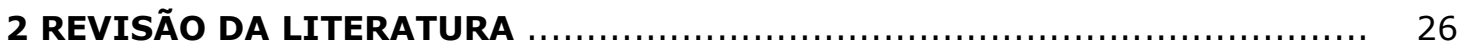

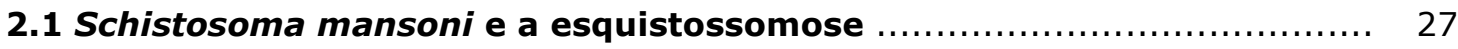

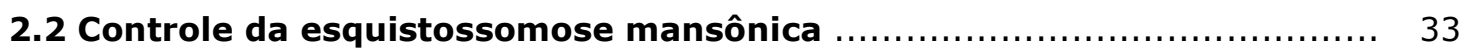

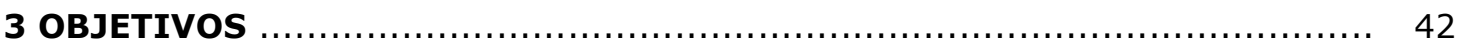

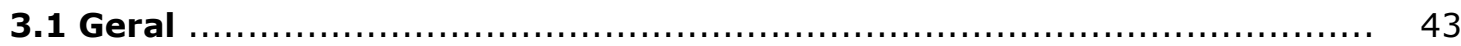

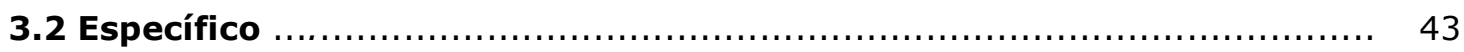

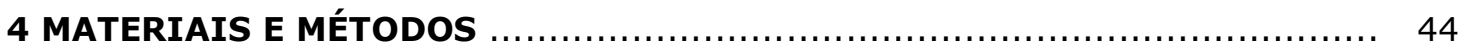

4.1 Animais utilizados e manutenção do ciclo evolutivo de Schistosoma

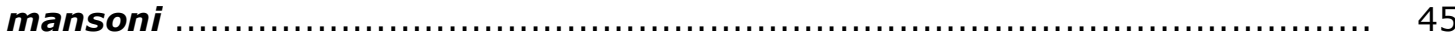

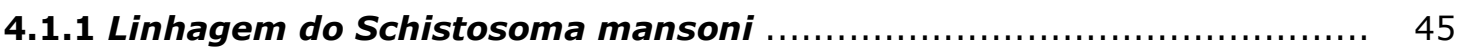

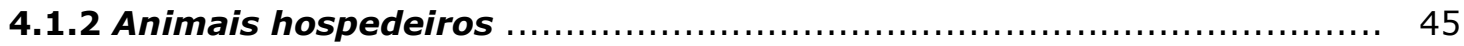

4.1.3 Manutenção do ciclo evolutivo de Schistosoma mansoni ................ 45

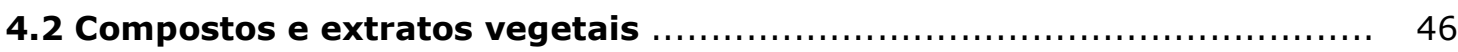

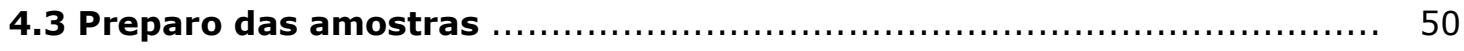

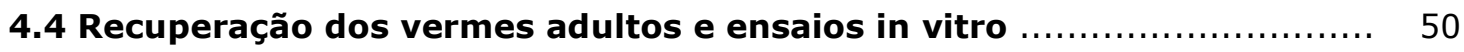

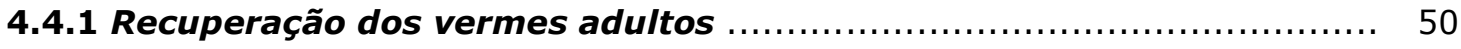

4.4.2 Ensaios in vitro com vermes adultos ................................... 51

4.5 Obtenção de esquistossômulos de diferentes idades e ensaios in vitro . 51

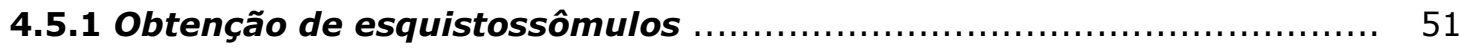

4.5.2 Ensaios in vitro com esquistossômulos .................................. 52

4.6 Avaliação da atividade de compostos e extratos em adultos e

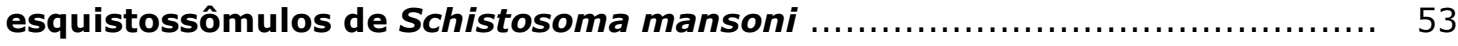

4.6.1 Avaliação da atividade de compostos e extratos em vermes adultos .. 53

4.6.2 Avaliação da atividade de compostos e extratos em

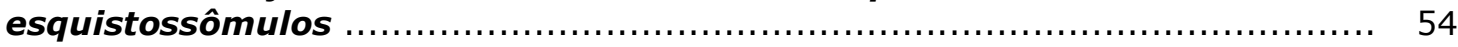


4.7 Análise morfológica no tegumento de adultos e esquistossômulos com microscopia confocal

4.8 Cultura de células e ensaios de citotoxicidade .......................... 55

4.8.1 Linhagem celular e condições de cultivo ................................. 55

4.8.2 Ensaios de citotoxicidade ........................................... 56

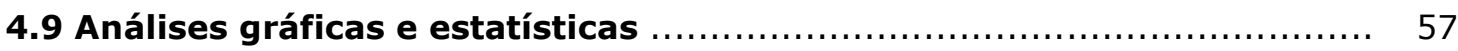

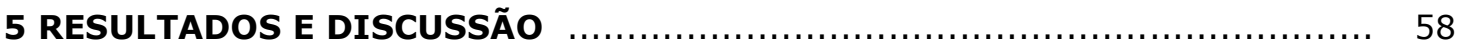

5.1 Viabilidade de adultos de Schistosoma mansoni em presença de

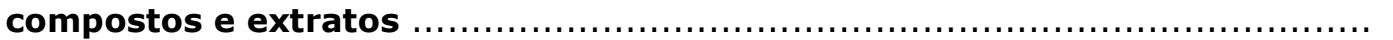

5.1.1 Alterações na viabilidade de adultos de Schistosoma mansoni em presença de compostos e extratos ..................................................

5.1.2 Efeito de compostos e extratos na atividade motora e no acasalamento de adultos de Schistosoma mansoni .............................. 74

5.2 Efeito de compostos e extratos no tegumento de adultos de

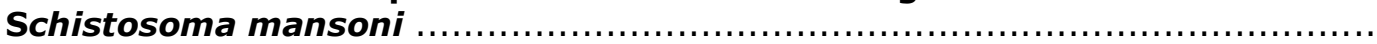

5.2.1 Alterações no tegumento de adultos de Schistosoma mansoni em presença de compostos e extratos

5.3 Efeito de compostos e extratos na oviposição de Schistosoma mansoni

5.3.1 Efeito de compostos e extratos, em concentrações subletais, na oviposição de adultos de Schistosoma mansoni

5.4 Alterações na viabilidade e no tegumento de esquistossômulos de Schistosoma mansoni, com diferentes idades, em presença de compostos e extratos

5.4.1 Alterações na viabilidade de esquistossômulos, com diferentes idades, em presença de compostos e extratos

5.4.2 Alterações no tegumento de esquistossômulos, com diferentes idades, em presença de compostos e extratos

5.5 Toxicidade de compostos e extratos em células de mamífero

5.5.1 Atividade citotóxica de compostos e extratos vegetais em células Vero 
ANEXOS

ANEXO A - Schistosoma mansoni: In vitro schistosomicidal activity of piplartine

ANEXO B - Evaluation of the in vitro activity of dermaseptin 01 , cationic antimicrobial peptide, against Schistosoma mansoni

ANEXO C - Evaluation of the in vitro activity of epiisopiloturin alkaloid isolated from jaborandi (Pilocarpus microphyllus Stapf ex Holm.; Rutaceae) against Schistosoma mansoni and Leishmania amazonensis 


\section{INTRODUÇÃO}


A esquistossomose é uma doença parasitária de grande impacto social, sendo considerada um importante problema de saúde pública em vários países. É causada pelo trematódeo digenético do gênero Schistosoma e apresenta formas agudas ou crônicas, com sintomatologia variada (FENWICK e WEBSTER, 2006; GRYSEELS et al., 2006).

Enquanto a maioria das parasitoses humanas vai diminuindo de importância, em função do desenvolvimento econômico e dos métodos de controle disponíveis, a esquistossomose encontra-se ainda em expansão, em muitas regiões do mundo, sendo endêmica em mais de 70 países. Estima-se a existência, em todo mundo, de mais de 200 milhões de indivíduos infectados e 800 milhões de pessoas estão expostas ao risco de contrair infecção. Esta helmintose é responsável por 280.000 a 500.000 mortes anualmente (DUPRÉ et al., 1999; STEINMANN et al., 2006). No Brasil, onde o Schistosoma mansoni é prevalente, a esquistossomose é endêmica em 19 estados. Acredita-se haver, no território nacional, entre 6 e 8 milhões de indivíduos infectados e 26 milhões correm o risco de infecção (AMARAL et al., 2006). De acordo com a Portaria $N^{\circ}$ 104, de 25 de janeiro de 2011 do Ministério da Saúde (MS), a esquistossomose faz parte da Lista de Notificação Compulsória (LCN), e a doença deverá ser registrada em áreas endêmicas e não endêmicas. Entretanto, os casos ainda são subnotificados (BRASIL, 2006, 2011).

A Organização Mundial de Saúde (OMS) incluiu a esquistossomose na sua lista de doenças negligenciadas e esta verminose continua sendo uma das principais causas de morbidade e mortalidade em todo o mundo. A esquistossomose incapacita ou mata milhares de pessoas e representa uma necessidade médica importante que permanece não atendida. Embora as doenças negligenciadas sejam responsáveis por $11,4 \%$ da carga global de doenças, apenas $21(1,3 \%)$ dos 1.556 novos medicamentos registrados entre 1975 e 2004 foram desenvolvidos especificamente para essas doenças. Durante o mesmo período, 1.535 medicamentos foram registrados para outras doenças (CHIRAC e TORREELE, 2006; HOTEZ et al., 2007).

Atualmente o tratamento quimioterápico da esquistossomose é baseado no uso de apenas um fármaco, praziquantel, mas seu uso extensivo e inapropriado culminou o aparecimento de resistência (CAFFREY, 2007; DOENHOFF et al., 2008). Além disso, o fármaco é eficaz somente contra as formas adultas do esquistossomoso, não atuando, portanto, nas formas jovens do parasita, os esquistossômulos (SABAH et al., 1986; UTZINGER et al., 2003). Dessa forma, é premente a necessidade de novas alternativas terapêuticas, especialmente com o uso de produtos naturais (NDAMBA et al., 1994; MØLGAARD et al., 2001; SANDERSON; BARTLETT; WHITFIELD, 2002; MOHAMED; METWALLY; MAHMOUD, 2005).

No presente estudo avaliou-se o efeito in vitro de 4 compostos isolados de espécies vegetais, as amidas piplartina e piperina, a lignana grandisina e o alcaloide 
epiisopiloturina; 1 composto isolado da pele de anfíbio, o peptídeo antimicrobiano dermaseptina 01; e de 6 extratos etanólicos obtidos de vegetais, Piper tuberculatum, $P$. crassinervium, P. diospyrifolium, P. fuligineum, P. gaudichaudianum e Pothomorphe umbellata em adultos (machos e fêmeas com 49 dias) e esquistossômulos (recémtransformados, 1, 3, 5 e 7 dias) de Schistosoma mansoni linhagem $\mathrm{BH}$.

Os compostos e extratos vegetais supracitados foram utilizados neste estudo devido alguns aspectos, entre os quais: a) apresentam diversas atividades biológicas conhecidas; b) as plantas são de fácil propagação e ciclo reprodutivo curto; c) as espécies apresentam ampla distribuição geográfica no território nacional e em diversas regiões do mundo; d) facilidade no isolamento de metabólitos secundários; e) alguns compostos já são sintetizados; f) os vegetais são comumente usados na medicina popular (PALMAR et al., 1997; PINHEIRO et al., 1997; JARAMILLO e MANOS, 2001; SANTOS e MORENO, 2004; PRASAD et al., 2005; KATO e FURLAN, 2007).

A piplartina \{5,6-dihydro-1-[1-oxo-3-(3,4,5-trimethoxyphenyl)-trans-2-propenyl]$2(1 \mathrm{H})$ pyridinone é uma amida encontrada em espécies do gênero Piper (PARMAR et al., 1997). Na sua forma pura, a piplartina é obtida com rendimento na faixa de $1 \%$ (BRAZFILHO et al., 1981; BEZERRA at al., 2006; CíCERO BEZERRA FELIPE et al., 2007). Esta substância apresenta diversas atividades biológicas avaliadas in vitro ou in vivo, tais como efeito ansiolítico e antidepressivo, anti-inflamatório, antiplaquetário e antitumoral (BEZERRA et al., 2005; 2006, 2008; CíCERO BEZERRA FELIPE et al., 2007; FONTENELE et al., 2009). A piplartina possui efeito inseticida para formigas e lagartas, bem como atividade antifúngica em Cladosporium sphaerospermum e C. cladosporioedes (CAPRON e WIEMER, 1996; NAVICKIENE et al., 2000, 2003; VASQUES DA SILVA et al., 2002). Além disso, o efeito antiparasitário in vitro da piplartina foi descrito em promastigota de Leishmania donovani e epimastigota de Trypanosoma cruzi (BODIWALA et al., 2007; COTINGUIBA et al., 2009).

A piperina \{1-[5-(1,3)-benzodioxol-5-yl)-1-oxo-2,4-pentadienyl]piperidine\} é uma amida encontrada nas espécies do gênero Piper, sendo o principal metabólito presente em Piper nigrum (pimenta do reino). A piperina é abundante principalmente nos frutos e foi a primeira amida a ser isolada das espécies de Piper. Na sua forma pura, a piperina é obtida com rendimento de $5 \%$ a $7 \%$. A piperina é a responsável pela sensação picante das pimentas, cujo consumo é apreciável em diversas regiões do mundo (PARMAR et al., 1997; CARDOSO et al., 2005). Apresenta diversas atividades biológicas, tais como ação antipirética, antioxidante, antitumoral, analgésica e anti-inflamatória (PARMAR et al., 1997; BEZERRA et al., 2005, 2006, 2008). A piperina também possui ação inseticida em formigas, baratas, besouros, traças, pulgões, lagartas, bem como em larvas de Musca domestica, Culex quinquefasciatus e Aedes aegypti (DAS et al., 1996; AHN et al., 1998; ESTRELA et al., 2003; SIMAS et al., 2007). A ação letal de piperina 
também foi relatada em ácaros, fungos e bactérias (AHN et al., 1998; VASQUES DA SILVA et al., 2002; KUMAR et al., 2008; SHARMA et al., 2010). Além disso, o efeito antiparasitário da piperina foi descrito in vitro em epimastigota e amastigota de Trypanosoma cruzi e in vivo em camundongos e hamsters infectados com Leishmania donovani (RAAY et al., 1999; RIBEIRO et al., 2004; VEERAREDDY; VOBALABOINA; NAHID, 2004; FREIRE-DE-LIMA et al., 2008).

A grandisina $\{(2 S, 3 S, 4 S, 5 S)-3,4$-dimethyl-2,5-bis(3,4,5 trimethoxyphenyl) oxolane\} é uma lignana encontrada em diversas espécies de plantas como Piper solmsianum (Piperaceae), Virola surinamensis (Myristicaceae), Rhaphidophora decursiva (Araceae), Aristolochia birostris (Aristolochiaceae), Aglaia leptantha (Meliaceae), Cryptocarya crassinervia e Nectandra megapotamica (Lauraceae) (SAAD et al., 1991; ZHANG et al., 2001; FRANÇA et al., 2005; da SILVA FILHO, 2008; CARVALHO et al., 2010). Este composto possui efeito larvicida em Aedes aegypti e ação ovicida e larvicida em mosca varejeira Chrysomya megacephala (CABRAL et al., 2009; NOGUEIRA et al., 2009). Além disso, a grandisina apresenta efeito antiparasitário in vitro em tripomastigota de Trypanosoma cruzi (LOPES et al., 1998; MARTINS et al., 2000, 2003).

A epiisopiloturina $\{2(3 \mathrm{H})$-furanone, dihydro-3-[(S)-hydroxyphenylmethyl]-4-[(1methyl-1H-imidazol-4-yl)methyl]-,(3S,4R)-\} é um alcaloide imidazólico encontrado em folhas de plantas do gênero Pilocarpus, popularmente conhecidas como jaborandi. É o segundo composto mais abundante nas folhas do jaborandi, depois da pilocarpina (ANDRADE-NETO, 1994; SANTOS e MORENO, 2004). Segundo David Lima, 2010 (comunicação pessoal; Vegeflora Extrações do Nordeste LTDA, Parnaíba, PI) o rendimento da epiisopiloturina é próximo de $1 \%$. Os efeitos biológicos da epiisopiloturina ainda são pouco conhecidos. Sua atividade antibacteriana foi avaliada in vitro em diversas linhagens de Escherichia coli, Staphylococcus aureus e S. epidermidis e não apresentou ação inibitória; e também não possuiu efeito antiviral quando testado em Dengue Virus (MIURA, 2009). Por outro lado, Miura et al., 2010 (prelo) mostraram que a epiisopiloturina possui ação antiparasitária em amastigota de Leishmania amazonensis.

As dermaseptinas representam uma família de peptídeos antimicrobianos catiônicos, de 24 a 34 resíduos de aminoácidos, encontrados na pele de anfíbios do gênero Phyllomedusa (MOR; HANI; NICOLAS, 1994; BRAND et al., 2002, 2006; LEQUIN et al., 2006). Estes peptídeos exercem atividade biocida em bactérias gram-positivas e gram-negativas, fungos filamentosos e leveduras, bem como apresentam efeito antiviral (FLEURY et al., 1998; BRAND et al., 2002; CHINCHAR et al., 2004; LORIN et al., 2005; LEITE et al., 2008). Além disso, o efeito antiparasitário das dermaseptinas foi descrito in vitro em tripomastigota e epimastigota de Trypanosoma cruzi, em promastigota de Leishmania amazonensis e L. chagasi e também na fase eritrocitária de Plasmodium falciparum (BRAND et al., 2002, 2006; DAGAN et al., 2002; ZAMPA et al., 2009). Em 
particular, a dermaseptina 01 é um peptídeo com 29 resíduos de aminoácidos que foi isolado da secreção cutânea de Phyllomedusa oreades, um pequeno anfíbio encontrado no Cerrado Brasileiro (BRAND et al., 2002). Estas moléculas antimicrobianas também exercem atividade contra bactérias, fungos e protozoários parasitas como Trypanosoma cruzi e Leishmania amazonensis (BRAND et al., 2002; LEITE et al., 2008; ZAMPA et al., 2009).

Plantas da família Piperaceae são muito conhecidas pela sua utilização como terapêuticos na medicina popular e por apresentar, em sua composição, diversas substâncias com propriedades biocidas (PARMAR et al., 1997; PRASAD et al., 2005). Os vegetais são usados na medicina alternativa contra febre, dores e inflamações em geral, antídotos no caso de acidentes com animais peçonhentos, além de aplicado contra reumatismo, asma, bronquite, hemorróidas, doenças gastrointestinais, respiratórias, cardiovasculares, renais. As espécies de Piperaceae também são usadas no tratamento de pele, com características fotoprotetoras e antitumorais, assim como são desintoxicantes para o organismo, melhora a imunidade e são utilizadas para emagrecimento (PARMAR et al., 1997; PRASAD et al., 2005). Extratos e compostos isolados de diferentes partes de Piperaceae (raiz, caule, folha, flor fruto e semente) foram avaliados quanto ao efeito biológico em diversos organismos. Piper tuberculatum, $P$. crassinervium e $P$. gaudichaudianum apresentam efeito fungicida (LAGO et al., 2004; MORANDIM et al., 2010). Piper tuberculatum também possui efeito inseticida em lagartas, besouros e larvas de Aedes atropalpus (SCOTT et al., 2002, 2004; REGASINI et al., 2009). Piper diospyrifolium e $P$. crassinervium apresentam atividade moluscicida em Biomphalaria tenagophila (RAPADO et al., 2010). Pothomorphe umbellata possui ação antibacteriana em Helicobacter pylori e também é utilizado como antimalárico na medicina popular (DE FERREIRA-DA-CRUZ et al., 2000; ISOBE et al., 2002). Além disso, $P$. tuberculatum, $P$. crassinervium e $P$. gaudichaudianum são tóxicos em epimastigotas de Trypanosoma cruzi (BATISTA et al., 2008; REGASINI et al., 2009). O valor nutricional de diversas espécies de Piperaceae é relativamente alto, por constituir boas fontes de vitaminas, e apresenta, ainda, caroteno, fibras cálcio, ferro, entre outros (PARMAR et al., 1997; PRASAD et al., 2005) 
2 REVISÃO DA LITERATURA 


\subsection{Schistosoma mansoni e a esquistossomose}

Helmintos do gênero Schistosoma pertencem ao filo Platyhelminthes, classe Trematoda e subclasse Digenea. Os trematódeos digenéticos são organismos inteiramente adaptados ao parasitismo, com um ciclo biológico complexo que envolve hospedeiros intermediários e definitivos. São achatados dorsoventralmente, de simetria bilateral, sem segmentação, tendo o tegumento coberto por uma citomembrana de aspecto sincicial. Os órgãos de fixação são constituídos por duas ventosas: a mais anterior, oral, onde se encontra a abertura bucal, e a ventral ou acetábulo. O sistema digestivo termina em um fundo cego, isto é, sem ânus (SCHELL, 1970). Muitas espécies de trematódeos afetam a população humana em regiões tropicais e subtropicais do mundo, particularmente nas áreas menos desenvolvidas. As esquistossomoses estão entre as doenças de mais alta endemicidade no planeta; elas são devidas a helmintos trematódeos do gênero Schistosoma (CHITSULO et al., 2000; STEINMANN et al., 2006).

As espécies de Schistosoma pertencem à família Schistosomatidae, que se caracteriza por apresentar sexos separados e acentuado dimorfismo sexual. Essa família possui parasitas que, em sua fase adulta, vivem nos vasos sanguíneos de mamíferos, aves e alguns répteis. Os parasitas do homem são todos do gênero Schistosoma, que determinam a doença denominada esquistossomose (CHITSULO et al., 2000; BROOKER; CLEMENTS; BUNDY, 2006; GRYSEELS et al., 2006; STEINMANN et al., 2006).

O Schistosoma mansoni adulto é tipicamente um helminto delgado e longo. O macho mede cerca de $1 \mathrm{~cm}$ de comprimento, formando um sulco longitudinal ou canal ginecóforo; é bem claro, com tegumento recoberto por minúsculos espinhos e tubérculos. A fêmea é mais delgada, medindo cerca de $1,5 \mathrm{~cm}$ de comprimento, é mais escura (acinzentada), em decorrência do sangue semidigerido presente no ceco e do pigmento dessa digestão, a homozoína. A topografia da superfície do corpo é bem mais simples que a do macho, com aspecto escavado. A superfície inteira do verme é recoberta por uma camada sincicial denominada de tegumento, o qual é ligado por estreitas conexões citoplasmáticas aos corpos celulares nucleados. As membranas apicais do tegumento, interface de contato entre o parasita e o hospedeiro, são constituídas por sete camadas (heptalaminar), cuja estrutura é formada por duas camadas lipídicas justapostas, constituindo o membranocálix. Essas camadas estão em contínuo processo de renovação, fato importante na capacidade de escape do helminto à resposta imune do hospedeiro (RACE et al., 1971; HOCKLEY, 1973). O acasalamento é fundamental para proteção da fêmea e, principalmente, para maturidade sexual, incluindo-se a produção de ovos, que são os responsáveis pela patologia da esquistossomose (ERASMUS, 1973, 1986; MACHADO-SILVA et al., 2008). 
As esquistossomoses, denominadas também esquitossomíases ou bilharzioses, são doenças que, para o homem, têm como os principais agentes etiológicos as espécies Schistosoma mansoni, S. intercalatum, S. haematobium, S. japonicum e S. mekongi (Figura 1). Schistosoma mansoni está presente em mais de 50 países nos continentes africano e americano, onde determina uma infecção denominada esquitossomose mansônica (CHITSULO et al., 2000; BROOKER; CLEMENTS; BUNDY, 2006; GRYSEELS et al., 2006).

No Brasil, a esquistossomose mansônica foi detectada pela primeira vez por Pirajá da Silva em 1907 no estado da Bahia, e ainda hoje é considerado um grande problema de saúde pública (AMARAL et al., 2006). A doença é conhecida popularmente por xistossomose, xistosa, doença dos caramujos ou mal dos caramujos, moléstia de Pirajá da Silva e, também, por "barriga d'água", devido à ascite que acompanha as formas mais graves com fibrose hepática. Atualmente, a esquistossomose mansônica é endêmica em 19 estados e no Distrito Federal (Figura 2). Em decorrência da intensa migração interna, existe uma zona endêmica quase contínua do Ceará ao Espírito Santo, concentrada principalmente na região costeira. Bahia e Minas Gerais são os estados mais endêmicos, com distribuição de casos em quase todo território (KATZ e PEIXOTO, 2000; AMARAL et al., 2006); focos isolados também foram assinalados nos estados do Pará, Goiás e na região Sul do país.

Em São Paulo, existem focos nos Vales do Ribeira, do Paraíba, do Tietê e do Paranapanema; nas Zonas Litorânea e Alta Sorocabana; além dos municípios de São Paulo, São Caetano do Sul, Guarulhos e Campinas (SILVA, 1985; REY, 2008; NEVES, 2005; AMARAL et al., 2006; MORAES, 2009). Segundo o Centro de Vigilância Epidemiológico (CVE) da Secretaria de Estado da Saúde de São Paulo, a maior ocorrência da doença é por casos importados, mas 22 municípios ainda registraram casos autóctones. No ano de 2005, por exemplo, foram confirmados 2.352 casos de esquistossomose, dos quais $72,3 \%$ eram importados (CVE, 2005). 

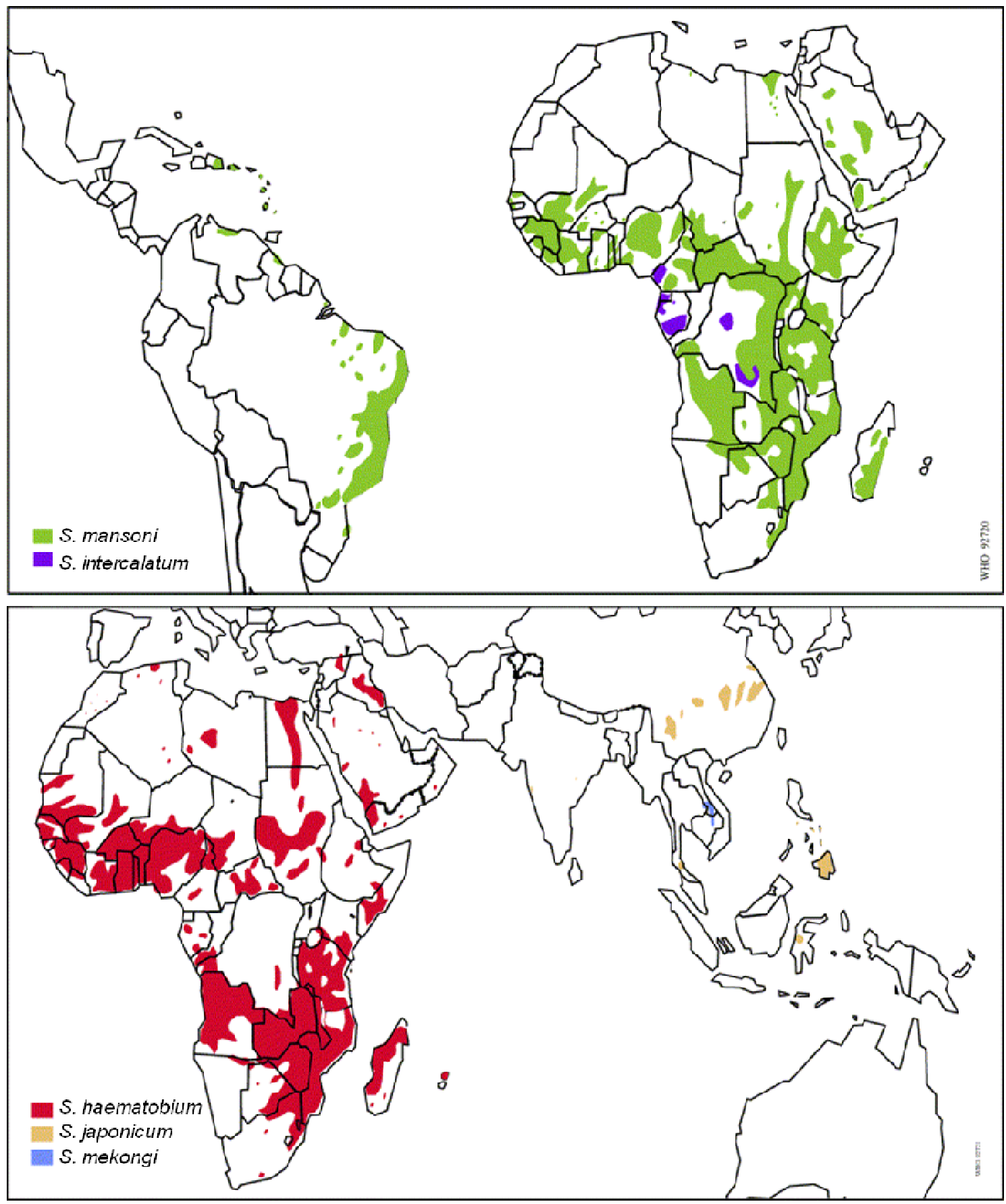

Figura 1. Distribuição global da esquistossomose. Distribuição da helmintose de acordo com seus agentes etiológicos: Schistosoma mansoni, S. intercalatum, S. haematobium, S. japonicum e S. mekongi.

Fonte: WHO (2011). 


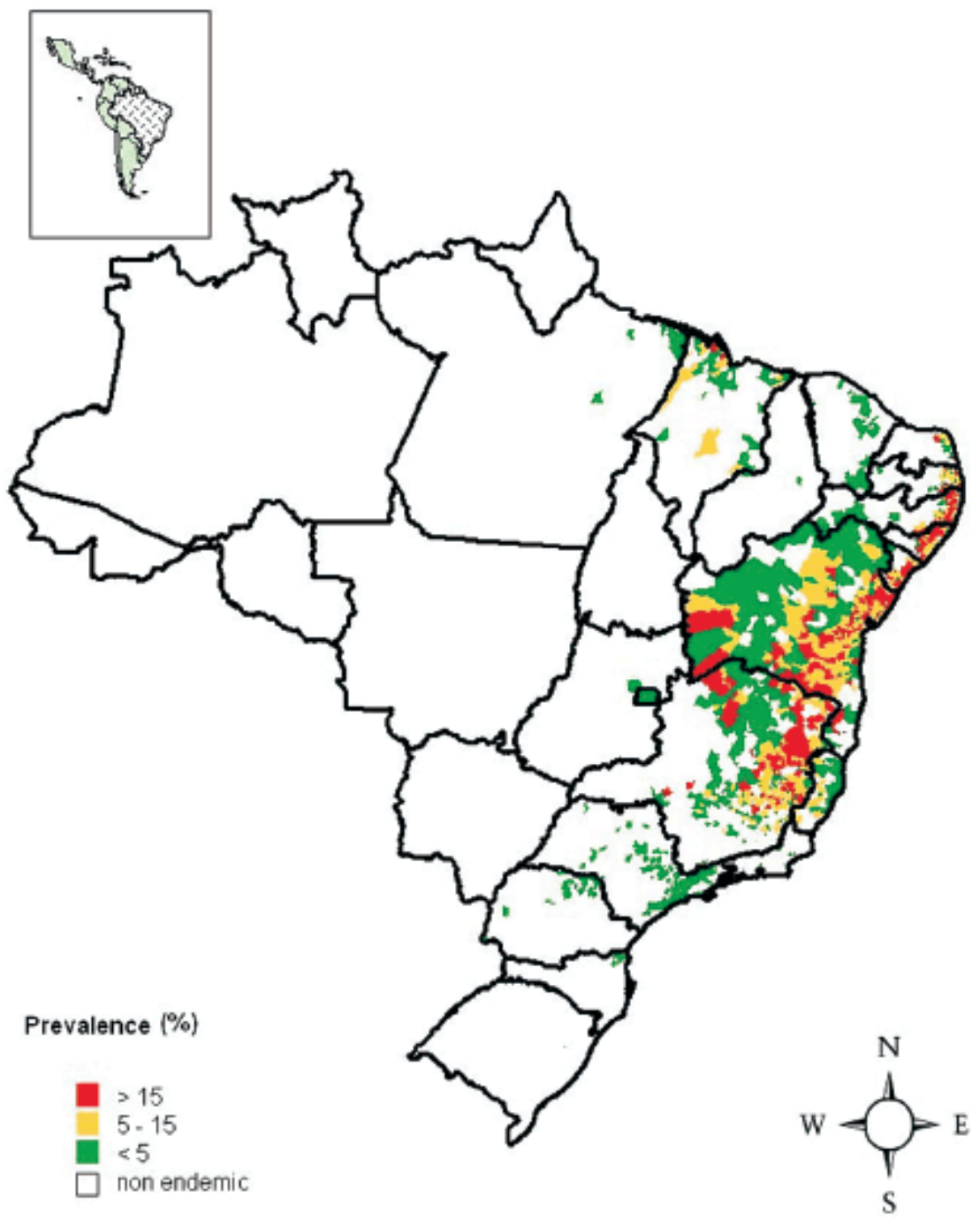

Figura 2. Distribuição da esquistossomose mansônica no Brasil, de acordo com o nível de prevalência dos municípios. Distribuição da verminose causada pelo Schistosoma mansoni.

Fonte: Amaral et al. (2006).

A esquistossomose mansônica é transmitida por caramujos de água doce, hermafroditas e pertencentes ao gênero Biomphalaria da família Planorbidae. Três espécies de Biomphalaria são responsáveis pela transmissão da esquistossomose no continente americano: B. glabrata, B. tenagophila e B. straminea. Biomphalaria glabrata é o principal vetor da esquistossomose no Brasil e é a espécie mais estudada devido a sua ampla distribuição geográfica e eficiência na suscetibilidade pelo parasita, apresentando altos índices de infecção natural e experimental (MORGAN et al., 2001; PARAENSE, 2001).

Schistosoma mansoni possui uma biologia muito interessante, pois passa por diversas fases e vive em hospedeiros e ambientes diversificados, com uma grande 
capacidade de adaptação, multiplicação e resistência. As fases do ciclo biológico do $S$. mansoni compreendem dois períodos de vida parasitária: um no hospedeiro intermediário e outro no hospedeiro definitivo. Entre as fases parasitárias há dois períodos de vida livre em meio aquático: as fases de miracídio e cercária (ROSS et al., 2002; BLANCHARD, 2004; GRYSEELS et al., 2006). Schistosoma mansoni, em geral, realizam ciclo assexuado nos moluscos do gênero Biomphalaria, enquanto que os espécimes adultos são encontrados nos vasos mesentéricos e no sistema porta de mamíferos das ordens Primates, Rodentia, Artiodactyla e Carnivora. O ciclo de vida do S. mansoni está representado na Figura 3.

Os vermes adultos de $S$. mansoni alojam-se aos pares em vênulas terminais do plexo mesentérico inferior que drenam a parede intestinal. A cada dia, cerca de 300 ovos medindo 110-180 $\mu \mathrm{m}$ por 45-70 $\mu \mathrm{m}$, são eliminados pela fêmea no interior das vênulas. Com base em modelos experimentais, estima-se que entre a metade e um terço desses ovos chegam ao meio externo através das fezes. A inflamação que a presença dos ovos desperta no hospedeiro pode resultar em ruptura da parede da vênula, liberando os ovos nos tecidos perivasculares e, finalmente, na luz intestinal. Cinco anos é a vida média do S. mansoni, embora alguns casais possam viver mais de 30 anos eliminando ovos (ROSS et al., 2002; GRYSEELS et al., 2006).

Quando as fezes contendo ovos do parasita entram em contato com a água, os ovos se rompem e liberam os miracídios, forma larvária do helminto que penetra no caramujo. No interior dos moluscos os parasitas se multiplicam dando origem às cercárias, que são liberadas na água após cerca de 30 dias. Penetrando através da pele, a cercária perde a cauda transformando-se em esquistossômulo. Ganhando acesso aos vasos e à circulação sistêmica, os parasitas jovens migram através dos pulmões e do fígado. Cerca de 5 semanas após a infecção, já estando alojados nas veias mesentéricas, os vermes atingem a maturidade sexual e tem início a postura de ovos, de modo que eles aparecem nas fezes cerca de 40 dias após a penetração das cercárias. Dessa forma, no hospedeiro vertebrado, o parasita passa de cercária para esquistossômulo de pele, esquistossômulo pulmonar, verme imaturo (adulto jovem) e verme adulto macho ou fêmea (ROSS et al., 2002; BLANCHARD, 2004; GRYSEELS et al., 2006). 


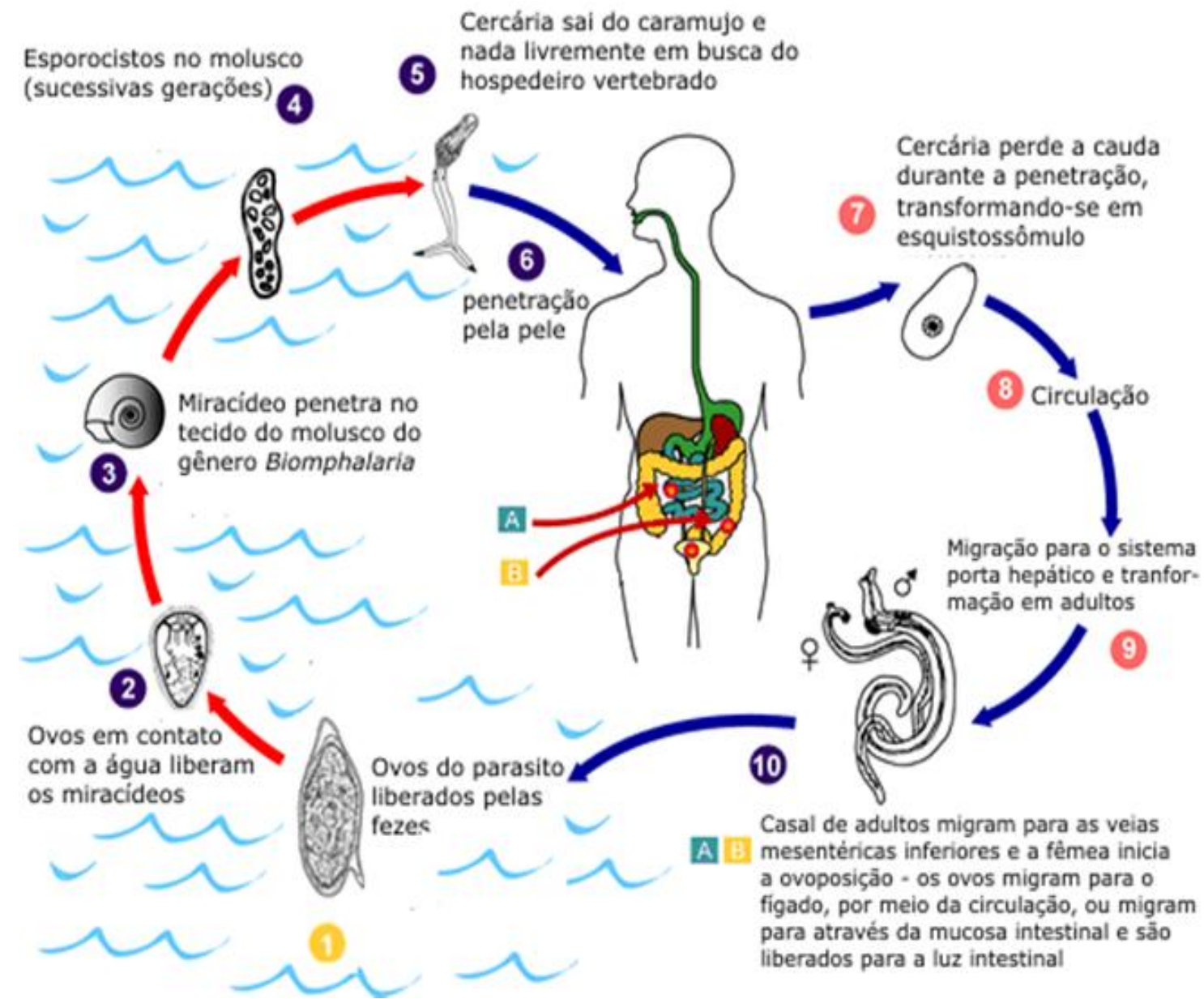

Figura 3. Ciclo de vida do Schistosoma mansoni.

Fonte: CVE (2005).

Os vários aspectos patogênicos e patológicos observados na esquistossomose mansônica dependem da interação parasito-hospedeiro nas três fases evolutivas e migratórias do verme no hospedeiro definitivo: esquistossômulo, verme adulto e ovo. Não há dúvida que, de longe, os ovos e a reação granulomatosa que os envolvem constituem os principais fatores causadores da morbidade. A infecção por Schistosoma mansoni costuma ser oligossintomática com predominância intestinal; mas pode produzir alterações anatomopatológicas cujo caráter e gravidade cobre extensa gama de situações, o que imprime a essa doença grande polimorfismo e, em muitos casos, prognóstico incerto. Assim, a esquistossomose deve ser encarada como uma doença de múltiplos mecanismos, com lesões diretamente ligadas à presença local do agente etiológico (cercárias, esquitossômulos, vermes adultos, ovos), alterações hemodinâmicas, alterações de reatividade imunológica, lesões à distância devidas a imunocomplexos, e alterações gerais sobre o organismo, além de interagir e favorecer outras patologias por agentes infecciosos. Nas formas mais graves, há predominância de hepatoesplenomegalia e fibrose periportal. Entre os vários fatores dos quais a patogenia 
da helmintose está ligada, os mais importantes são a carga parasitária, que influencia diretamente no número de ovos, e a resposta do sistema imunológico de cada hospedeiro (BLANCHARD, 2004; WYNN et al., 2004; YOSRY, 2006; GRYSEELS et al., 2006; SECOR, 2006; WILSON et al., 2007).

\subsection{Controle da esquistossomose mansônica}

O controle da esquistossomose permanece um grande desafio para os países endêmicos. As estratégias de controle baseiam-se em programas públicos de saneamento básico, educação sanitária, controle do hospedeiro intermediário e tratamentos das pessoas infectadas. O impacto econômico da esquistossomose é sentido por vários grupos sociais, principalmente pelos países mais pobres e pelas populações que vivem sob condições mais difíceis. O abastecimento de água tratada, as instalações sanitárias e o destino adequado dos esgotos sanitários são os recursos básicos de saneamento que, associados à educação sanitária, constituem o melhor método de controle da doença em médio e longo prazo. Entretanto, tais medidas estão muito distantes nas áreas endêmicas (BERGQUIST, 2002; BROOKER; CLEMENTS; BUNDY, 2006; FENWICK et al., 2006; STEINMANN et al., 2006). Além disso, conscientizar a população e mudar os seus hábitos não é uma tarefa fácil, uma vez que a população, especialmente mulheres e crianças, depende das coleções hídricas para suas atividades domésticas e pessoais, além de usá-las como áreas de lazer (Figura 4).

A transmissão da esquistossomose ocorre devido à presença de moluscos do gênero Biomphalaria infectados nas coleções hídricas, por isso, o combate ao hospedeiro intermediário é importante para o controle da doença. Por outro lado, o controle do caramujo é considerado complexo devido seu alto potencial reprodutivo e capacidade de adaptação em diferentes ambientes. Além disso, esses moluscos hermafroditas são capazes de autofecundação e, portanto, repovoar criadouros em um curto período de tempo. O controle de moluscos pode ser feito com alguns métodos, a saber: a) ambientais, como canalização, aterro, assoreamento, drenagem, limpeza de margens; b) biológicos, com a presença de predadores como, por exemplo, peixes e aves, além de microorganismos que podem esterilizar os caramujos e; c) químicos, como adição de substâncias moluscicidas. Na prática, no entanto, esses métodos de controle são complexos, dispendiosos, causam alterações no ambiente e dificilmente são empregados nas áreas endêmicas (TELES e CARVALHO, 2008). 


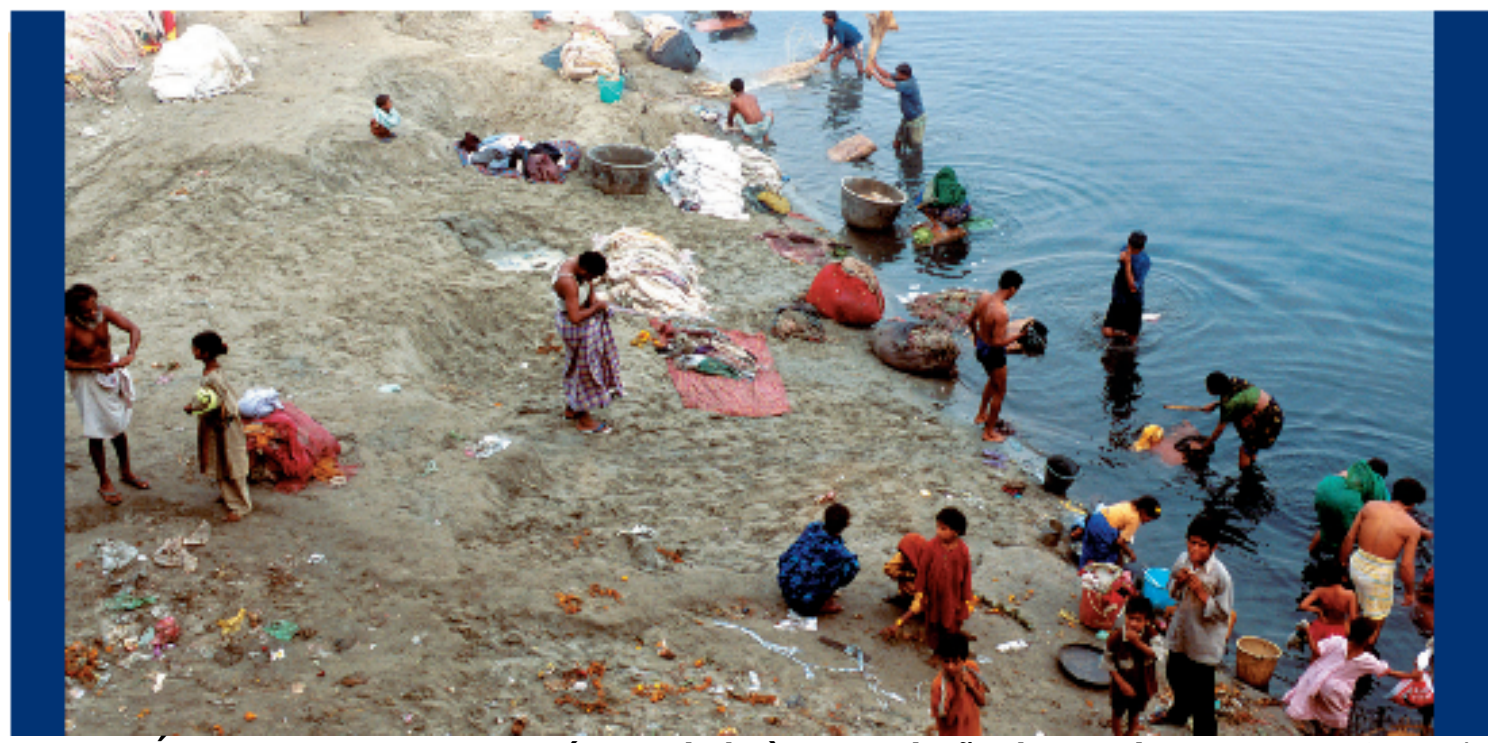

Figura 4. Área que comumente está associado à transmissão da esquistossomose. Segundo a OMS é o local que normalmente está associado à transmissão da esquistossomose em diversas regiões do mundo.

Fonte: WHO (2009).

Associada à luta antivetorial, ao saneamento do meio e a outras medidas práticas, a quimioterapia é, no entanto, a forma mais eficaz no controle da esquistossomose (FENWICK et al., 2003; HOTEZ et al., 2010; ZHANG et al., 2010). O tratamento desta parasitose sempre foi limitado pela dificuldade de serem encontrados quimioterápicos que exibissem alta eficácia e grande tolerabilidade. No início, na década de 1910, foi utilizado o tártaro emético (tartarato de antimônio e potássio). Em seguida, vários sais de antimômio foram introduzidos em uso clínico, a saber, dissulfonato-bis-pirocatecol de sódio e antimônio (Stibofen), gluconato de antimônio e sódio (Tiostam) e tiomalato de antimônio e sódio (Anthiomaline) administrados por via intramuscular ou intravenosa (CIOLI; PICA-MATTOCCIA; ARCHER, 1995; CIOLI, 1998). Os derivados antimoniais, que foram a base da quimioterapia da esquistossomose durante quase 50 anos, apesar de atuarem com eficácia contra as três principais espécies do gênero Schistosoma, o $S$. mansoni, o S. haematobium e o S. japonicum, deixaram de ser usados no tratamento desta helmintose, por ocasionarem inúmeros efeitos colaterais e tóxicos, com alterações nas células sanguíneas, além de, não raramente, ocorrência de morte súbita (CIOLI; PICA-MATTOCCIA; ARCHER, 1995; CIOLI, 1998).

Após a Segunda Guerra Mundial, o cloridrato de 1-N-dietil-amino-etil-amino-4metil-9-tioxantona, a lucantona (miracil D), passou a ser o primeiro esquistossomicida conhecido de uso oral, mas apenas na década de 1960 houve um avanço na terapia da esquistossomose com o surgimento da hicantona, do niridazol, dos nitrofuranos e do metrifonato. A hidrometilação da lucantona deu origem ao fármaco ativo por via oral e dose única, o 1-N-b-dietil-amino-etil-amino-4-(hidroximetil)-9-tioxantona, a hicantona, 
com eficácia, especificamente, contra o S. mansoni e o S. haematobium. Entretanto, efeitos tóxicos e graves apareceram com o uso da hicantona (Etrenol), causando óbitos, inclusive no Brasil, por lesões hepáticas agudas, o que, portanto, deixou a terapêutica da esquistossomose sem opção (ANDRADE et al., 1974). O niridazol (Ambilhar), outro fármaco de uso oral e eficaz contra $S$. haematobium e S. japonicum, exigia administração por cerca de uma semana; no entanto, apresentava baixa tolerância, especialmente causando convulsão, alucinação e outros efeitos indesejáveis sobre o sistema nervoso central, além de lesões hepáticas e renais. O niridazol também apresentou mutagenicidade, carcinogenicidade, ação imunossupressora e, por conta disso, teve seu uso proscrito (KATZ, 1977; CIOLI; PICA-MATTOCCIA; ARCHER, 1995). Ainda na década de 1960, dois compostos surgiram para o tratamento da esquistossomose: os nitrofuranos e o metrifonato. Os nitrofuranos são antimicrobianos de amplo espectro e foram utilizados pelos chineses em pessoas infectadas com $S$. japonicum; entretanto, a ação esquistossomicida era somente em doses que apresentavam toxicidade ao hospedeiro e, portanto, logo deixou de ser utilizado. No mesmo período, o metrifonato, um organofosforado inibidor de acetilcolinesterase, passou a ser utilizado; mas seu uso, que ainda persiste até os dias de hoje, tem sido limitado aos casos de esquistossomose urinária (CIOLI; PICA-MATTOCCIA; ARCHER, 1995).

Na década de 1970, funcionários da indústria farmacêutica Pfizer (Sandwich, Inglaterra) descreveram uma série de derivados 2-aminometil-tetra-hidroquinolínicos que apresentaram ação marcante esquistossomicida, sendo que o mais promissor foi o UK-3883. Esse composto, além de ação curativa em dose oral única, apresentou também atividade profilática e ação contra todos os estágios em camundongos. A hidroxilação do grupo 6-metil deu origem ao UK 4271, posteriormente denominado oxamniquina, na qual em dose oral única apresenta elevada atividade curativa contra $S$. mansoni em roedores e primatas. Em todos os hospedeiros, os vermes machos mostraram-se mais susceptíveis à droga do que as fêmeas. O novo esquistossomicida recebeu o nome comercial de Mansil ${ }^{\circledR}$, que é uma mistura das palavras "mansoni" e "Brasil", onde foram realizados os primeiros ensaios clínicos com essa droga. Ensaios clínicos no Brasil mostraram que a dose oral única de $15 \mathrm{mg} / \mathrm{kg}$ a $20 \mathrm{mg} / \mathrm{kg}$ apresentava boa tolerância, poucos efeitos tóxicos e índice de cura de até $90 \%$ nos pacientes. Apesar do registro de alguns efeitos colaterais como tonturas, náuseas, cefaléia e sonolência, os ensaios clínicos demonstraram boa aceitação pela população pesquisada e impacto imediato sobre as manifestações clínicas, além de reduzir a prevalência da parasitose. Dessa forma, assim, esses resultados favoráveis permitiram que o fármaco pudesse ser aplicado a milhares de pessoas, sem grandes riscos, pelo Ministério da Saúde brasileiro por iniciativa do Programa Especial de Controle da Esquistossomose (PECE). Após mais de 13 millhões de 
tratamentos realizados nas áreas endêmicas de esquistossomose pode-se concluir que a oxamniquina é um fármaco eficaz para tratamento individual ou em larga escala, mas chama a atenção que seu preço elevado é um fator limitante a sua maior disseminação, principalmente como medida de saúde pública. A oxamniquina é ineficaz nas outras espécies de Schistosoma e seu uso ficou mais direcionado aos países da América do Sul, principalmente o Brasil. A oxamniquina é mais ativa para eliminar os machos do que as fêmeas do parasita, no entanto as fêmeas que sobrevivem ao tratamento deixam de colocar ovos, cessando assim a progressão da doença. A oxamniquina provoca o desprendimento dos parasitas dos seus lugares de fixação no interior das veias mesentéricas e são arrastados então até o fígado onde são destruídos. O mecanismo de ação da oxamniquina parece estar relacionado com sua capacidade de inibição da síntese de ácidos nucléicos nos vermes. Diversos relatos de resistência, efeitos colaterais consideráveis, alto custo e especificidade somente com uma espécie de esquistosoma estão tornando o uso da oxamniquina cada vez mais restrito (CIOLI; PICA-MATTOCCIA; ARCHER, 1993, 1995).

Na década de 1970, ainda, iniciaram-se estudos conjuntos entre os laboratórios Bayer e Merck com derivados de pirazinoisoquinolínicos como antiparasitários. Após síntese de mais de quatrocentos compostos o mais promissor revelou ser o \{2-(ciclohexilcarbonil)-1,2,3,6,7,11b-hexa-hidro-4H-pirazino[2,1-a]isoquinolina-4-one\}, praziquantel. Além da atividade tóxica em cestóides e trematóides, o praziquantel foi o primeiro fármaco que mostrou atividade acentuada, por via oral ou intramuscular, em dose única, contra todas as espécies de Schistosoma que acometem o homem. A ação anti-helmíntica do praziquantel deve-se provavelmente na alteração dos canais de $\mathrm{Ca}^{2+}$ dos esquistossomos, aumentando a permeabilidade da membrana do helminto a certos cátions monovalentes e divalentes, principalmente o cálcio, o que leva à intensificação da atividade muscular, seguida por contração e paralisia espástica. Como consequência, os helmintos se separam dos tecidos do hospedeiro e são rapidamente deslocados das veias mesentéricas para o fígado e, após algumas horas, há vacuolização em diferentes partes do tegumento. Assim, são três as principais ações do praziquantel sobre os vermes: contração muscular, lesão do tegumento e alterações metabólicas. Atualmente, o praziquantel é o único fármaco recomendo pela OMS (MEHLHORN et al., 1981; DOENHOFF; KIMANI; CIOLI, 2000; DOENHOFF; CIOLI; UTZINGER, 2008; CIOLI e PICAMATTOCCIA, 2003; WHO, 1985, 2002).

Nos últimos 30 anos houve uma significativa melhora na eficiência terapêutica do tratamento contra a esquistossomose com a introdução do praziquantel, que, administrado em dose única, por via oral, apresenta atividade terapêutica elevada. 0 tratamento com praziquantel $(40 \mathrm{mg} / \mathrm{kg}$ a $60 \mathrm{mg} / \mathrm{kg}$, dependendo da espécie de Schistosoma) é eficaz na redução da morbidade, porém os resultados com o uso dessa 
droga têm sido menos promissores do que o esperado. Além de não atuar nas formas jovens do parasita, existem relatos de resistência ao fármaco (BENNET et al., 1997; CIOLI et al., 2000; LIANG et al., 2001; DOENHOFF; KIMANI; CIOLI, 2000; DOENHOFF et al., 2002; CIOLI e PICA-MATTOCCIA, 2003; GRYSEELS et al., 2001; FENWICK e WEBSTER, 2006).

A população que reside em área endêmica de esquistossomose precisa ser submetida a tratamentos sequenciais, existindo, portanto, a possibilidade da seleção de linhagens de S. mansoni resistentes aos fármacos. Rogers e Bueding (1971) demonstraram, pela primeira vez, a existência de uma linhagem de $S$. mansoni resistente a um agente esquistossomicida; no caso, a hicantona. No Brasil, a resistência à hicantona foi relatada pela primeira vez por Katz et al. (1973). Vários estudos posteriores confirmaram a presença de linhagens resistentes aos agentes esquistossomicidas, incluindo oxamniquina e praziquantel (DIAS et al., 1978; De SOUZA DIAS; de JESUS PEDRO; DEBERALDINI, 1982; COLES et al., 1987; CIOLI; PICAMATTOCCIA; ARCHER, 1993; FALLON e DOENHOEF, 1994; ISMAIL et al., 1996, 1999; COELHO; LIMA e SILVA; NOGUEIRA-MACHADO, 1997; CONCEIÇÃO; ARGENTO, CORRÊA, 2000; LIANG et al., 2001; WILLIAN et al., 2001).

O desenvolvimento de tolerância ou resistência ao praziquantel justifica a pesquisa e produção de novas drogas para prevenção e cura da esquistossomose. De fato, desde a descoberta do praziquantel nos anos 1970, pouco avanço terapêutico foi alcançado. Estudos nos anos 1980 demonstram atividade esquistossomicida promissora do imunossupressor ciclosporina A (BOUT; DESLÉE; CAPRON, 1984, 1986; CHAPPELL et al., 1987). Entretanto, investigações ainda estão sendo realizadas com o intuito de elucidar o mecanismo de ação e possíveis efeitos adversos (CIOLI, 1998). No início da década de 1980, a artemisina, uma lactona sesquiterpênica obtida das folhas de Arthemisia annua, e derivados, especialmente o arteméter e o artenusato, foram utilizados como agente esquistossomicida na China, inicialmente com o S. japonicum; posteriormente, ficou demonstrado que os compostos possuem atividade esquistossomicida contras as outras espécies que parasitam o homem (XIAO et al., 2002; UTZINGER et al., 2001, 2003). Diferentemente da oxamniquina e do praziquantel, a atividade dos derivados de artemisina é maior nas formas jovens do que nos vermes adultos (XIAO et al., 2002). Por apresentar atividade acentuada contra vermes imaturos, o arteméter vem sendo ensaiado, em áreas endêmicas, como droga profilática na esquistossomose; mas com atenção, pois o arteméter é um importante antimalárico e seu uso inapropriado poderá causar o aparecimento de resistência nos agentes etiolócos da malária (CHIPPAUX et al., 2003; FENWICK et al., 2003; UTZINGER et al., 2001, 2003; KEISER et al., 2009). 
No século XXI, intensificou-se a busca por novos compostos com características esquistossomicidas, mas ainda falta a avaliação na terapêutica clínica (Tabela 1). Abdulla et al. (2007) mostraram que o vinil sulfona K11777, um inibidor de cisteíno protease, possui interessante efeito esquistossomicida. Esses inibidores de proteases também são potenciais fármacos para a doença de Chagas (BARR et al., 2005). Embora tenha mostrado redução significativa da carga parasitária de camundongos infectados, o mecanismo de ação e possíveis efeitos adversos precisam ser investigados durante a terapêutica experimental (ABDULLA et al., 2007). No mesmo ano de 2007, foram assinalados que os antimaláricos trioxolanos possuem considerável atividade esquistossomicida (XIAO et al., 2007). Posteriormente, Sayed et al. (2008) descreveram que oxadiazóis são esquistossomicidas quando administrados, diariamente, por até cinco dias, em camundongos infectados com S. mansoni. A mefloquina, um aminoálcool usado como antimalárico, é um composto promissor, pois apresenta efeito esquistossomicida em parasitas jovens e adultos quando administrados por via oral em camundongos (VAN NASSAUW et al., 2008; KEISER et al., 2009). Mais recentemente, El Ridi et al. (2010) mostraram, em S. mansoni e S. haematobium, que o ácido araquidônico apresenta propriedade esquistossomicida. Finalmente, em 2011 foi mostrado que a miltefosina, um importante fármaco para o tratamento de leshmaniose, também reduz a carga parasitária de camundongos com esquistossomose mansônica (EISSA et al., 2011). Na Tabela 1 está uma lista de compostos esquistossomicidas utilizados na terapêutica experimental ou clínica da esquistossomose.

Considerando a dificuldade na descoberta de esquistossomicidas, a alternativa pode estar nos produtos naturais. De fato, a atividade anti-helmintica de plantas é bem conhecida na medicina tradicional em muitas regiões do mundo. Extratos de diferentes partes de plantas ou de seus frutos são preparados por curandeiros, que representam o conhecimento empírico e cultural em comunidades do mundo inteiro (NDAMBA et al., 1994; CLARK; APPLETON; KVALSVIG, 1997; SPARG et al., 2000; MOLGAARD et al., 2001). Na Ásia e África existem diversas evidências de que preparados como esses são eficazes contra parasitas, o que destaca a fitoterapia como uma ferramenta em potencial para o controle das parasitoses. O modo de ação ou substância química que causa dano ao parasita foi muito pouco investigado. São necessários, portanto, mais estudos para confirmar o real valor terapêutico dessas plantas no tratamento das doenças parasitárias (NDAMBA et al., 1994; CLARK; APPLETON; KVALSVIG, 1997; SPARG et al., 2000; MOLGAARD et al., 2001). Nesse contexto, a busca por extratos e compostos naturais com propriedades esquistossomicidas tem aumentado nos últimos anos. A tabela 2 apresenta uma lista de extratos ou compostos naturais que são tóxicos, in vitro, para os esquistossomos. 

Tabela 1 - Compostos com características esquistossomicidas usados na terapêutica
experimental ou clínica da esquistossomose

\begin{tabular}{|c|c|c|}
\hline Data* & Compostos & Observações \\
\hline 1918 & Antimoniais $^{a}$ & Altamente tóxicos \\
\hline 1920 & Emetina $^{a}$ & Moderadamente efetivo; tóxico \\
\hline 1960 & Metrifonato ${ }^{a}$ & Ainda usado em S. haematobium \\
\hline 1962 & Nitrofuranos ${ }^{a}$ & Moderadamente efetivo \\
\hline 1962 & Lucantona $^{a}$ & Substituído pela hicantona \\
\hline 1964 & Niridazol ${ }^{a}$ & Oral; moderadamente efetivo \\
\hline 1965 & Hicantona ${ }^{a}$ & Uso descontinuado por mutagenicidade \\
\hline 1969 & Oxamniquina ${ }^{a}$ & Ainda usado em S. mansoni \\
\hline 1971 & Tubercidina $^{a}$ & Ativo em animais; nenhum teste em humanos \\
\hline 1976 & Amoscanato ${ }^{a}$ & Amplamente testado na China; tóxico \\
\hline 1977 & Praziquantel ${ }^{a}$ & Fármaco de escolha para todas as esquistossomoses \\
\hline 1978 & Ro $11-3128^{a}$ & Benzodiazepínico: efetivo em vermes imaturos \\
\hline 1978 & Oltipraz ${ }^{a}$ & Uso descontinuado por causar problemas na unha \\
\hline 1981 & Ciclosporina $A^{a}$ & $\begin{array}{c}\text { Ativo em animais; nenhum teste em humanos; curativo e } \\
\text { profilático }\end{array}$ \\
\hline 1984 & 9-Acridanona-hidrazona ${ }^{a}$ & Ativo em animais; nenhum teste em humanos \\
\hline 1980 & Artemisina $^{b}$ & Moderadamente efetivo; baixa solubilidade \\
\hline 1982 & Arteméter $^{\mathrm{b}}$ & Efetivo em vermes imaturos \\
\hline 1983 & Artenusato ${ }^{b}$ & Efetivo em vermes imaturos \\
\hline 2007 & Vinil sulfona $\mathrm{K} 11777^{\mathrm{c}}$ & Ativo em animais; nenhum teste em humanos \\
\hline 2007 & Trioxalanos $^{d}$ & $\begin{array}{c}\text { Moderadamente efetivo em parasitas jovens e adultos; ativo } \\
\text { em animais; nenhum teste em humanos }\end{array}$ \\
\hline 2008 & Oxadiazóis e & $\begin{array}{c}\text { Moderadamente efetivo em parasitas jovens e adultos; ativo } \\
\text { em animais; nenhum teste em humanos }\end{array}$ \\
\hline 2008 & Mefloquina ${ }^{f, g}$ & $\begin{array}{c}\text { Oral; efetivo em parasitas jovens e adultos; ativo em } \\
\text { animais; nenhum teste em humanos }\end{array}$ \\
\hline 2010 & Ácido aracdônico ${ }^{\mathrm{h}}$ & $\begin{array}{c}\text { Oral; efetivo em parasitas jovens e adultos; ativo em } \\
\text { animais; nenhum teste em humanos }\end{array}$ \\
\hline 2011 & Miltefosina ${ }^{i}$ & $\begin{array}{c}\text { Oral; efetivo em parasitas jovens e adultos; ativo em } \\
\text { animais; nenhum teste em humanos }\end{array}$ \\
\hline
\end{tabular}




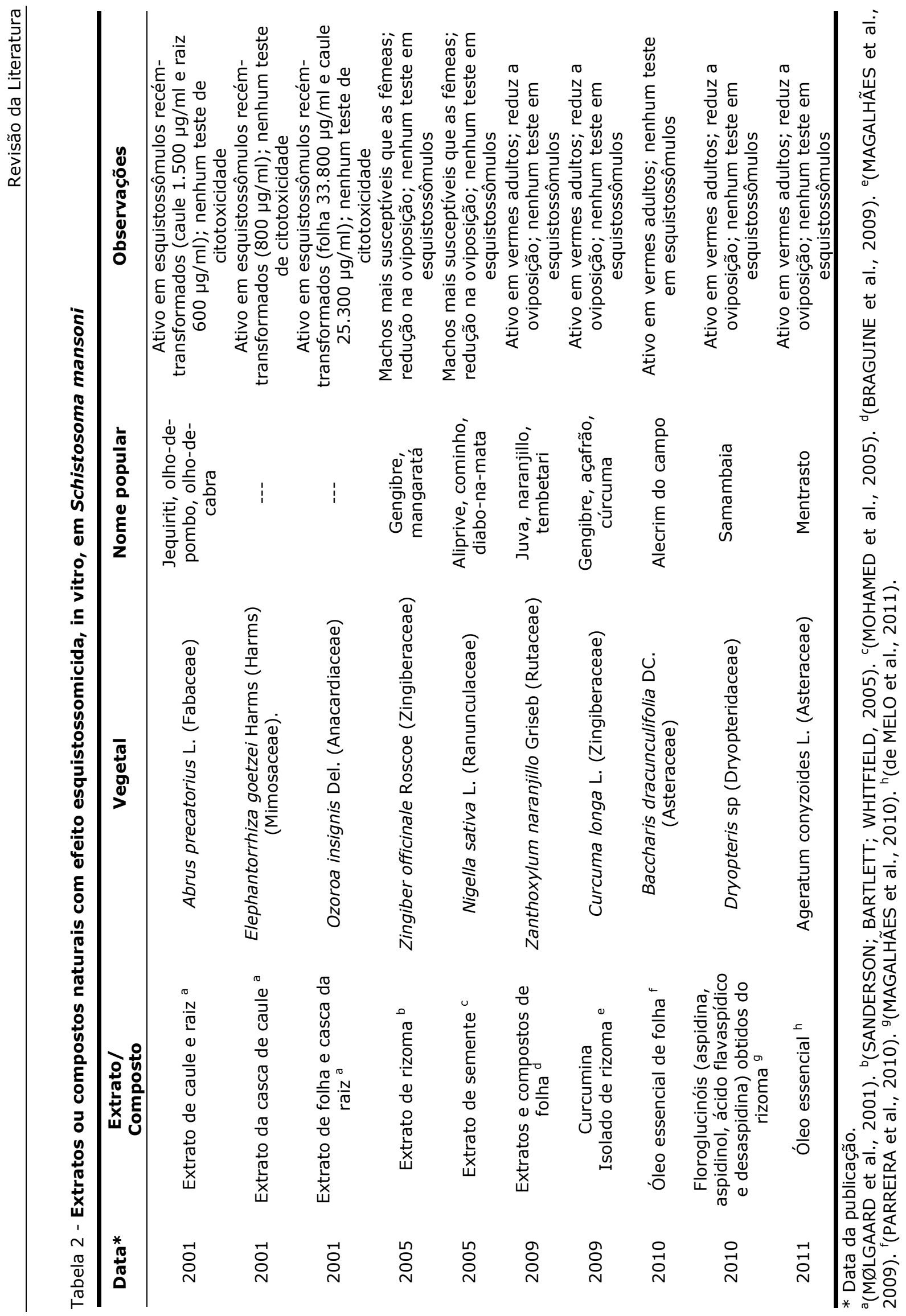


As estratégias da quimioterapia podem ser direcionadas para toda a população de uma determinada área endêmica (quimioterapia em massa) ou segmentos da população (quimioterapia dirigida). A disponibilidade de apenas um fármaco para o tratamento de dezenas de milhões de pessoas com esquistossomose é um fato preocupante nos últimos anos. É possível que com o advento do praziquantel, associado à ocorrência da esquistossomose em países subdesenvolvidos ou em desenvolvimento, o que implica, portanto, na baixa capacidade de compra, tenha feito com que as indústrias farmacêuticas não se interessem em promover investimentos vultosos para descobrirem novos fármacos contra essa importante parasitose (TOUILLER et al., 2002; HOTEZ et al., 2007). Nesse sentido, a OMS classificou a esquistossomose como uma doença negligenciada (REMME et al., 2002; FENWICK et al., 2003; CAFFFREY, 2007). E, de fato, a falha no sistema em vigor para desenvolver novos fármacos de interesse foi enfatizada pela organização não governamental Mécins Sans Frontières (MSF, em português: Médicos Sem Fronteiras), que salientou a necessidade de haver novas iniciativas, envolvendo órgãos públicos, instituições de pesquisas e unidades de produção. A organização MSF destinou os recursos recebidos pelo Prêmio Nobel da Paz, em 1999, ao desenvolvimento de um modelo alternativo de pesquisa e desenvolvimento de novos medicamentos para tratar as doenças negligenciadas. Como resultado dessa ação, em 2003, sete organizações de diferentes países uniram esforços para fundar a iniciativa Drugs for Neglected Diseases initiative (DNDi, em português: Medicamentos para Doenças Negligenciadas).

Acredita-se que a alternativa pode estar na exploração dos produtos naturais (BLEICHER et al., 2003). Tendo em vista a biodiversidade no território brasileiro, o Bioprospecta, em associação com o Programa Biota/FAPESP, iniciou um programa que procura drogas potenciais no tratamento de doenças tropicais e outras patologias. Os estudos de bioprospecção visam à descoberta de produtos biologicamente ativos (como esquistossomicidas), esperando contribuir para programas de desenvolvimento autosustentável, pelo uso de produtos naturais. Nesse sentido, a triagem de compostos e extratos esquistossomicidas in vitro apresenta uma abordagem inicialmente importante.

Neste trabalho é apresentado o efeito de 4 compostos isolados de espécies vegetais, 1 composto isolado da pele de anfíbio e 6 extratos etanólicos obtidos de vegetais em adultos e esquistossômulos de Schistosoma mansoni. Os resultados e discussões estão divididos em 6 partes, sendo complementados por 3 artigos que estão anexados no final do manuscrito. 
3 OBJETIVOS 


\subsection{Geral}

Avaliar o efeito in vitro de compostos (epiisopiloturina, grandisina, piperina, piplartina e dermaseptina 01) e extratos (Piper tuberculatum, $P$. crassinervium, $P$. diospyrifolium, P. fuligineum, $P$. gaudichaudianum e Pothomorphe umbellata) naturais em Schistosoma mansoni.

\subsection{Específicos}

1) Avaliar a viabilidade de vermes adultos em presença de compostos e extratos;

2) Avaliar o efeito de compostos e extratos no tegumento de vermes adultos;

3) Avaliar a capacidade reprodutiva, pelo acasalamento e oviposição dos parasitas, quando em presença de compostos e extratos;

4) Avaliar o efeito de compostos e extratos na viabilidade e no tegumento de esquistossômulos;

5) Avaliar a toxicidade de compostos e extratos em células de mamífero. 


\section{MATERIAIS E MÉTODOS}




\subsection{Animais utilizados e manutenção do ciclo evolutivo de schistosoma mansoni}

\subsubsection{Linhagem do Schistosoma mansoni}

A linhagem de Schistosoma mansoni Sambon, 1907 utilizada neste trabalho foi a $\mathrm{BH}$ (Belo Horizonte, MG), mantida no Laboratório de Parasitologia do Instituto Butantan (São Paulo, SP). Os parasitas foram mantidos em caramujos Biomphalaria glabrata Say, 1818 (hospedeiro intermediário) e hamsters Mesocricetus auratus Waterhouse, 1839 (hospedeiro definitivo).

\subsubsection{Animais hospedeiros}

Os caramujos são procedentes de Barreiro de Baixo (Belo Horizonte, MG, Brasil). Eles foram mantidos em aquários de polietileno $(55 \times 22 \times 17 \mathrm{~cm})$ com cerca de 20 litros de água desclorada, em temperatura de $24{ }^{\circ} \mathrm{C}$, e alimentados com alface fresca; os aquários eram arejados com bombas de 1,5 W (MORAES et al., 2009).

Os hamsters foram fornecidos pelo Biotério Central do Instituto Butantan. Eles foram mantidos em caixas de polipropileno $(40 \times 34 \times 16 \mathrm{~cm})$ com tampa metálica e alimentados com ração e água ad libitum. Esses roedores eram recém-desmamados, de um único sexo, com massa de aproximadamente $20 \mathrm{~g}$ e 21 dias de idade. Os animais eram acomodados em maravalha com duas trocas semanais.

\subsubsection{Manutenção do ciclo evolutivo de Schistosoma mansoni}

A manutenção do ciclo evolutivo de $S$. mansoni foi feita de acordo com Pellegrino e Katz (1968). Os hamsters foram infectados subcutaneamente (com seringa de $1 \mathrm{ml}$ ) com cerca de 150 cercárias. Após 49 dias, os roedores eram sacrificados em câmara de $\mathrm{CO}_{2}$ para a retirada do fígado e obtenção dos miracídios. Os fígados eram triturados em liquidificador em solução salina $0,85 \%(\mathrm{~m} / \mathrm{v})$, e a suspensão dos tecidos homogeneizados era deixada para sedimentação no escuro. Após lavagens por decantações sucessivas, o sedimento era suspenso com água desclorada e exposto à luz para obtenção dos miracídios. O número e a viabilidade dos miracídios e cercárias foram determinados com o auxílio de um estereomicrocópio (PELLEGRINO e KATZ, 1968).

Para a infecção do hospedeiro intermediário foram utilizados 10 miracídios por caramujo. Os moluscos sexualmente maduros eram colocados, individualmente, em placas de cultura de células ( 24 poços) contendo água filtrada. A exposição do molusco aos miracídios foi realizada sob a luz artificial (lâmpada incandescente de $60 \mathrm{~W}$ ) a uma distância de aproximadamente $30 \mathrm{~cm}$, durante 3 a 4 horas. Tal procedimento promove 
aumento da temperatura para cerca de $30^{\circ} \mathrm{C}$. Após 35 a 40 dias, os caramujos eram examinados, colocando-os individualmente em placas de 24 poços e expostos à luz artificial para a eliminação das cercárias, durante 2 a 3 horas. Os exemplares infectados foram protegidos da luz com a colocação de papel escuro em torno do aquário para evitar a liberação de cercárias (PELLEGRINO e KATZ, 1968).

Para infecção do hospedeiro definitivo, cerca de 30 caramujos infectados eram

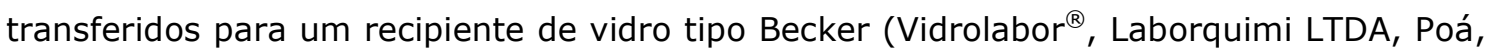
SP, Brasil) contendo água desclorada e expostos à luz artificial para liberação de cercárias. Para concentração cercariana, os parasitas eram transferidos para tubos de ensaio em vidro com capacidade de $40 \mathrm{ml}$ (Pyrex ${ }^{\circledR}$, Corning Incorporated, Corning, NY, USA) parcialmente protegidos da luz com papel alumínio, de modo que a entrada de luz era somente no ápice. As cercárias foram utilizadas na infecção dos hamsters (PELLEGRINO e KATZ, 1968).

\subsection{Compostos e extratos vegetais}

Os compostos piplartina, piperina e grandisina e os extratos etanóicos obtidos das folhas ou flores de Piper tuberculatum Jacq., Piper crassinervium Kunth, Piper diospyrifolium Kunth, Piper fuligineum Kunth, Piper gaudichaudianum Kunth e Pothomorphe umbellata (L.) Miq. foram cedidos pelo prof. Dr. Massuo J. Kato (Laboratório de Química de Produtos Naturais, Departamento de Química Fundamental, Instituto de Química, Universidade de São Paulo, IQ-USP). Os compostos dermaseptina 01 e epiisopiloturina foram cedidos pelo prof. Dr. José Roberto S. A. Leite (Núcleo de Pesquisa em Biodiversidade e Biotecnologia, Campus Ministro Reis Velloso, Universidade Federal do Piauí, UFPI). Como controle positivo foi utilizado o praziquantel, um fármaco comumente comercializado (Sigma-Aldrich Corporation, St. Louis, MO, USA ou Cestox ${ }^{\circledR}$, Merck S.A., Rio de Janeiro, RJ, Brasil). A origem e a característica dos compostos e extratos utilizados para verificar o efeito em Schistosoma mansoni são mostradas nas Tabelas 3 e 4 , enquanto que as estruturas químicas das moléculas e a sequência primária do peptídeo estão na Figura 5. 


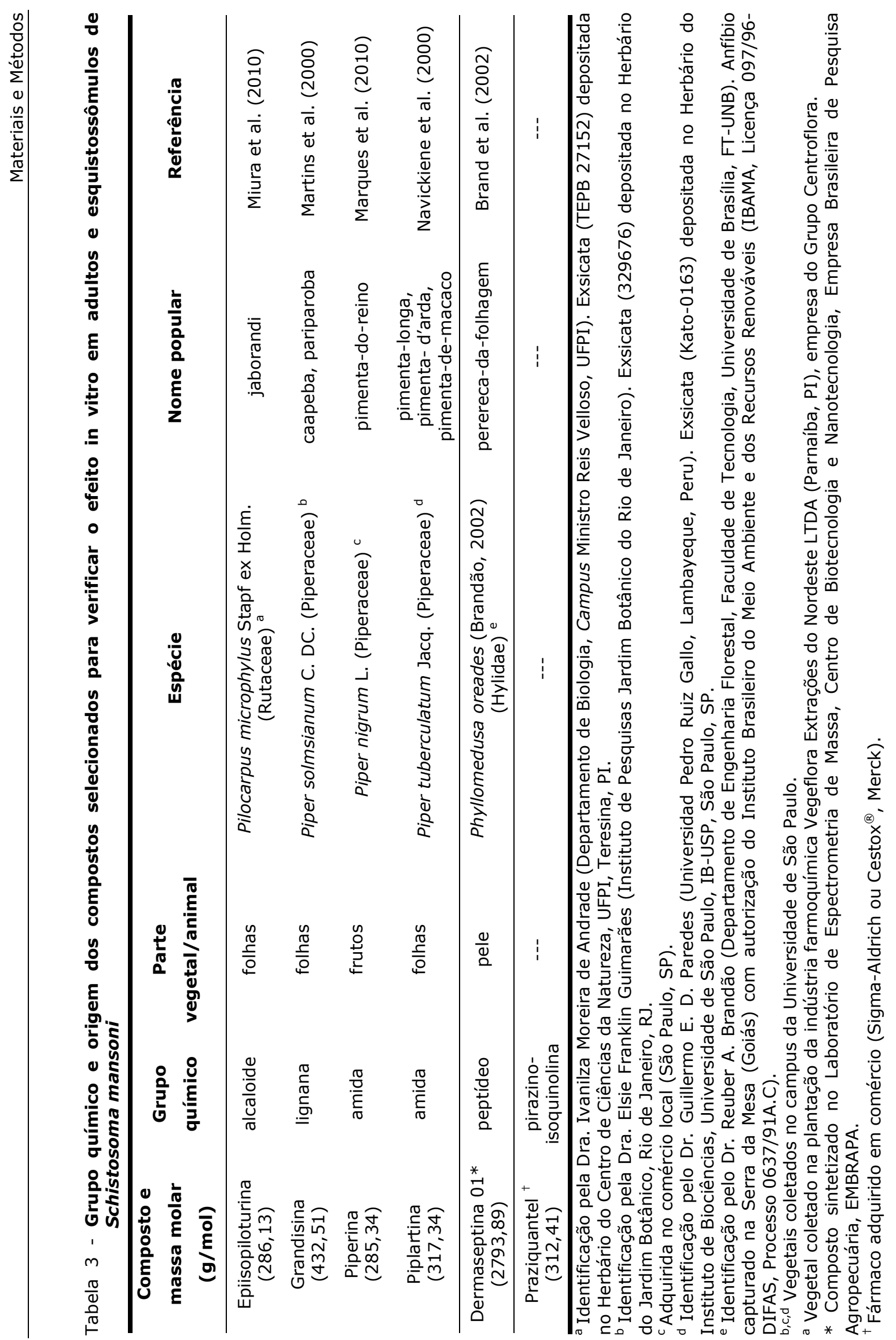


Tabela 4 - Espécies vegetais e origem dos extratos selecionados para verificar o efeito in vitro em adultos e esquistossômulos de Schistosoma mansoni

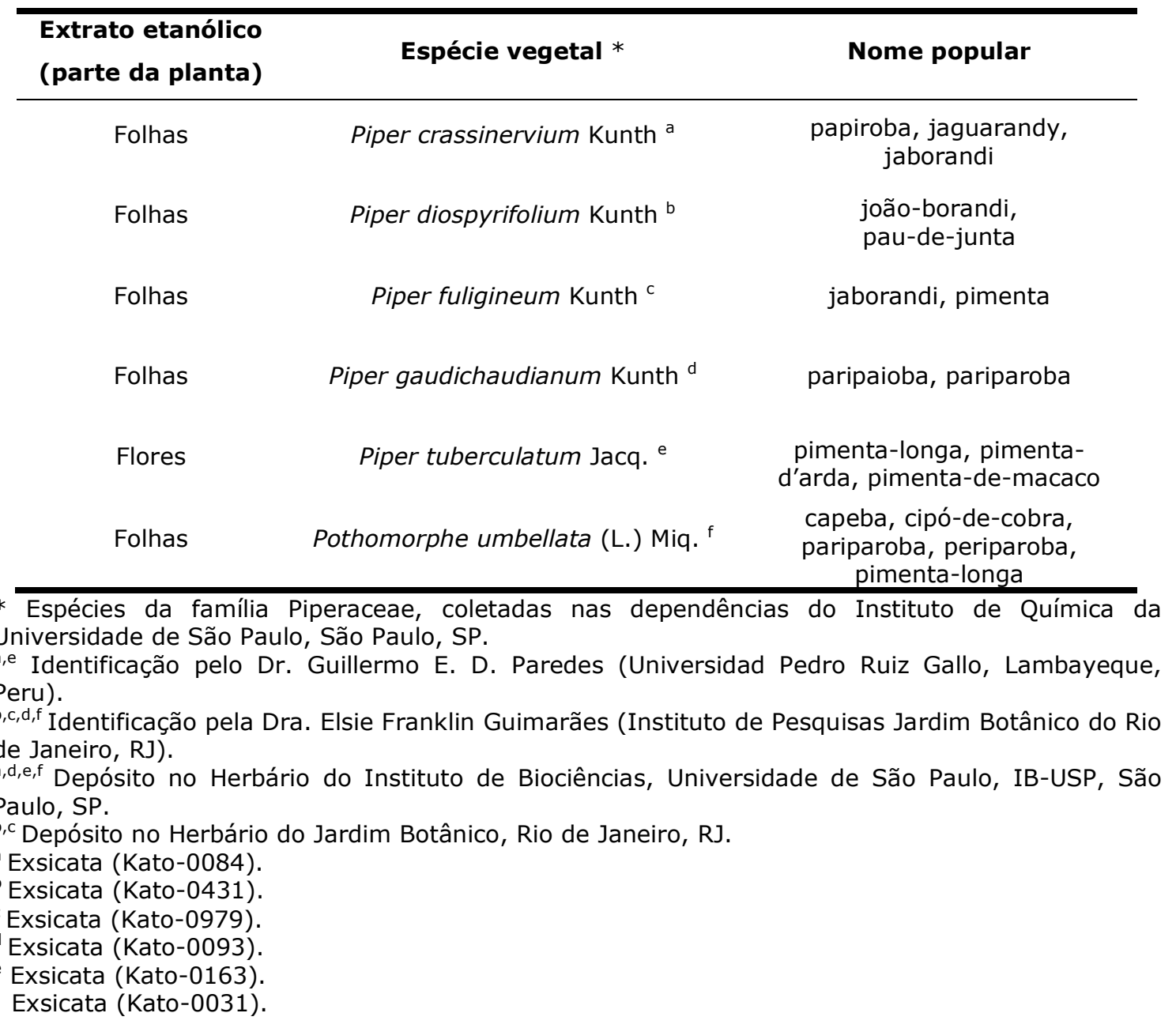


<smiles>Cn1cnc(CC2COC(=O)C2C(O)C2CCCCC2)c1</smiles>

epiisopiloturina<smiles>O=C(C=CC=Cc1ccc2c(c1)OCO2)N1CCCCC1</smiles>

piperina<smiles>O=C1CN(C(O)C2CCCCC2)CC2C3CC4CCC3(CCN12)C4</smiles>

praziquantel<smiles>COC1=CC([C@H]2OC(C3CC(OC)=C(OC)C(OC)C3)[C@H](C)C2C)=CC(OC)C1OC</smiles>

grandisina<smiles>COC1=C(OC)C(OC)C(OC)C=C1/C=C/C(O)N1CCCCC1=O</smiles>

piplartina

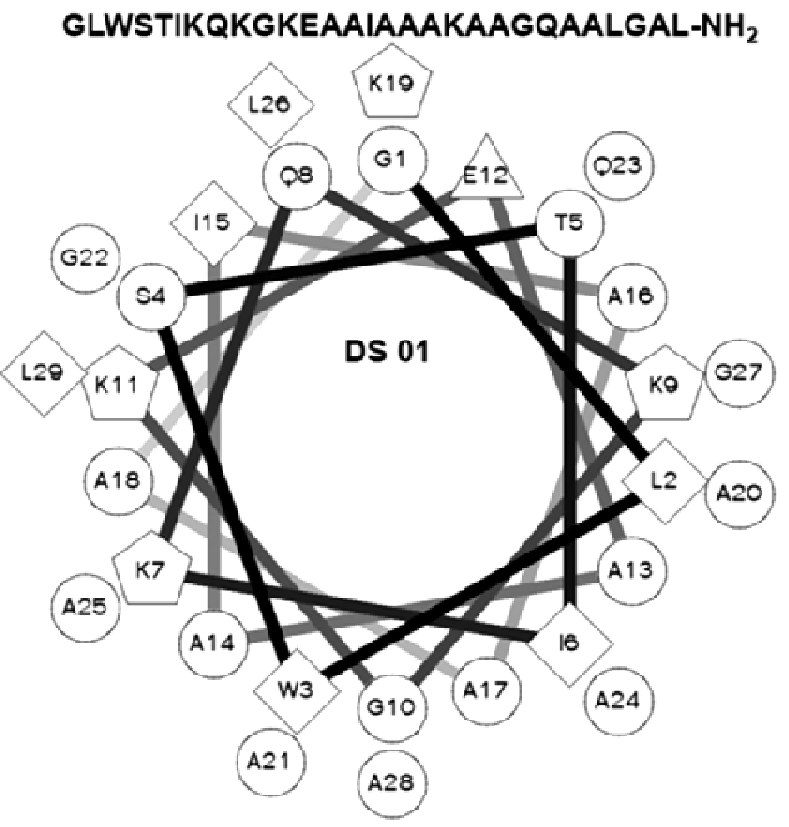

dermaseptina 01

Figura 5. Estrutura química das moléculas e sequência primária do peptídeo antimicrobiano dermaseptina. No caso do peptídeo, a projeção Helix-Wheel mostra os resíduos de aminoácidos positivamente carregados (pentágonos), alifáticos (losangos), polares não-carregados (círculos) e negativamente carregados (triângulos). 


\subsection{Preparo das amostras}

Os extratos e compostos foram recebidos secos, em frascos de vidro tipo âmbar ou em microtubos incolores de polipropileno protegidos da luz com papel alumínio, e conservados em temperatura ambiente em um local isento de umidade. No momento do uso, de $1 \mathrm{mg}$ a $4 \mathrm{mg}$ de extratos ou compostos eram transferidos, individualmente, em tubos de polipropileno de fundo cônico com capacidade de 1,5 ml (Axygen Inc, Union City, CA, USA) e dissolvidos em dimetilsulfóxido 100\% (DMSO, Merck); exceto a dermaseptina 01, pois apresenta alta solubilidade em água. Posteriormente, adicionou-se meio "Roswell Memorial Park Institute" (RPMI 1640) para obter uma concentração, de compostos ou extratos, de $1000 \mu \mathrm{g} / \mathrm{ml}$ a $4000 \mu \mathrm{g} / \mathrm{ml}$ em DMSO 2\% (v/v). O meio RPMI continha L-glutamina e vermelho de fenol (pó para preparo de 1 litro; Cultilab, Campinas, SP, Brasil) e era esterilizado por filtração. Para os ensaios com célula de mamífero empregou-se o meio Meio de Eagle Modificado por Dulbecco (DMEM), como descrito no item 4.8, ao invés do meio RMPI. Os compostos e extratos foram testados nos ensaios descritos nos itens 4.4.2, 4.5.2 e 4.8.2.

Quanto à solubilidade das amostras, os compostos piplartina e epiisopiloturina, assim como todos os extratos vegetais são muito solúveis em DMSO e, portanto, não apresentaram dificuldades durante o preparo. Por outro lado, grandisina, piperina e praziquantel são pouco solúveis e, mesmo no solvente, foi necessária uma agitação por tempo mais prolongado (cerca de 5 minutos), utilizando um agitador de tubo, tipo Vortex (modelo AP 56, Phenix LTDA, Araraquara, SP, Brasil).

\subsection{Recuperação dos vermes adultos e ensaios in vitro}

\subsubsection{Recuperação dos vermes adultos}

Os adultos de S. mansoni, com 49 dias de idade, foram recuperados por perfusão do sistema porta hepático como descrito por Smithers e Terry (1965). A perfusão foi realizada com meio RPMI 1640 contendo L-glutamina e vermelho de fenol (pó para preparo de 1 litro, Cultilab) e heparina sódica $5 \mathrm{UI} / \mathrm{ml}$ (Liquemine ${ }^{\circledR}$, Roche, São Paulo, $\mathrm{SP}$, Brasil). Os hamsters foram sacrificados por inalação de $\mathrm{CO}_{2} \mathrm{e}$, posteriormente, fez-se uma secção longitudinal na região ventral, expondo-se os órgãos internos. A veia porta foi seccionada e, com o auxílio de uma agulha acoplada a uma bomba peristáltica, injetou-se meio de cultura diretamente no coração do animal para coleta dos vermes adultos (SMITHERS e TERRY, 1965). 


\subsubsection{Ensaios in vitro com vermes adultos}

Os ensaios in vitro com adultos de S. mansoni foram realizados com machos e fêmeas acasalados. Os pares de vermes obtidos dos hamsters por perfusão foram lavados 2 vezes com o meio RPMI 1640 (descrito no item 4.4.1), esterilizado por filtração (Corning), contendo penicilina $200 \mathrm{U} / \mathrm{ml}$, estreptomicina $200 \mu \mathrm{g} / \mathrm{ml}$ e anfotericina B 2 $\mu \mathrm{g} / \mathrm{ml}$ (Cultilab); procedimento este feito em placa de Petri de polietileno estéril, com duas divisões $(90 \mathrm{~mm} \times 15 \mathrm{~mm}$ ). Posteriormente, os parasitas acasalados foram transferidos em placas para cultura de células com 24 poços (TTP ${ }^{\circledR}$, Techno Plastic Products, St. Louis, MO, USA) contendo, por poço, 1 casal de vermes em $2 \mathrm{ml}$ do meio RPMI 1640 supracitado, porém o meio era suplementado com 10\% de soro fetal bovino (Cultilab) e tamponado com HEPES 25 mM (Sigma-Aldrich) (XIAO e CATTO, 1989; RAMIREZ et al., 2007; XIAO et al., 2007; EL RIDI et al., 2010; MORAES et al., 2011a, 2011b).

Diferentes concentrações de compostos e extratos foram diluídas no meio de cultura antes da adição dos parasitas, sendo que concentração final de DMSO não foi superior a $0,2 \%$. Praziquantel $3 \mu \mathrm{g} / \mathrm{ml}$ foi utilizado como controle positivo e poços contendo somente meio de cultura ou meio com DMSO $0,2 \%$ foram usados como controle negativo. As culturas foram mantidas a $37{ }^{\circ} \mathrm{C}$, em atmosfera de $\mathrm{CO}_{2}$ a $5 \%$ (estufa Revco ${ }^{\circledR}$, Thermo Electron Corporation, Barrington, IL, USA) e foram monitoradas diariamente por 5 dias, com o auxílio de um microscópio invertido e um estereomicroscópio (SMZ 1000, Nikon, Melville, NY, U.S.A) (XIAO e CATTO, 1989; RAMIREZ et al., 2007; XIAO et al., 2007; MORAES et al., 2011a, 2011b).

\subsection{Obtenção de esquistossômulos de diferentes idades e ensaios in vitro}

\subsubsection{Obtenção de esquistossômulos}

As cercárias foram mecanicamente transformadas em esquistossômulos pelo método de Ramalho-Pinto et al. (1974) e os parasitas foram cultivados in vitro como descrito por Basch (1981). As cercárias foram concentradas (como descrito no item 4.1.3), distribuídas em tubos de polipropileno de fundo cônico com capacidade de $50 \mathrm{ml}$ (Corning ou Falcon, Laboratories Inc Pecan St. Colorado Springs, CO, EUA) e deixadas em banho de gelo por 30 minutos. Após centrifugação a $200 \mathrm{xg}$, por 2 minutos a $4{ }^{\circ} \mathrm{C}$ (centrífuga modelo 5810R, Eppendorf, Barkhausenweg, Hamburg, Germany), os parasitas eram ressuspensos em meio RPMI 1640 contendo antibióticos, mas sem soro (como descrito no item 4.3), e foram submetidos à transformação mecânica utilizando-se um agitador de tubos, tipo Vortex (Phenix), com rotação entre 3000 rpm e 3800 rpm por 
cerca de 90 minutos (RAMALHO-PINTO et al., 1974; KEISER, 2010). A suspensão com corpos cercarianos (esquistossômulos) e caudas era transferida para garrafas plásticas para cultura de células (área de $75 \mathrm{~cm}^{2}$, TPP) contendo meio RPMI e então mantidas a 37 ${ }^{\circ} \mathrm{C}$, em atmosfera de $\mathrm{CO}_{2}$ a $5 \%(\mathrm{BASCH}, 1981)$. Após 3 horas de incubação, as culturas foram lavadas por centrifugação ( 250 x g, 1 minuto) ou decantação sucessiva (por cerca de 8 minutos) para separar o esquistossômulo da cauda cercariana.

\subsubsection{Ensaios in vitro com esquistossômulos}

Os esquistossômulos foram incubados em meio 169 por até sete dias antes da realização dos ensaios. Os experimentos foram realizados com esquistossômulos recémtransformados, 1, 3, 5 e 7 dias de idade, sendo que a idade desses parasitas jovens foi contada in vitro (BASCH, 1981a). De fato, neste meio de cultura o parasita é capaz de sobreviver por semanas, preservando sua capacidade de desenvolvimento no hospedeiro (BASCH, 1981a, 1981b; BASCH e HUMBERT, 1981). A composição do meio 169 está descrita na Tabela 5.

Os esquistossômulos foram distribuídos em placas para cultura de células, com 96 poços de fundo chato (Corning ou TPP), contendo, por poço, cerca de 50 parasitas em meio 169, e então mantidos a $37{ }^{\circ} \mathrm{C}$, em atmosfera de $\mathrm{CO}_{2}$ a $5 \%$. Após diferentes tempos, o sobrenadante foi recolhido e o meio 169 contendo compostos ou extratos em DMSO $0,2 \%$ foi adicionado às culturas. Praziquantel com diferentes concentrações foi utilizado como controle positivo e poços contendo somente meio de cultura ou meio com DMSO $0,2 \%$ foram usados como controle negativo. As culturas foram mantidas a $37{ }^{\circ} \mathrm{C}$, em atmosfera de $\mathrm{CO}_{2}$ a $5 \%$, e monitoradas diariamente por 5 dias, com o auxílio de um microscópio invertido (ABDULLA et al., 2009). Os esquistossômulos foram monitorados quanto à viabilidade e as alterações no tegumento, como descrito no item 4.6.2. 
Tabela 5 - Composição do meio 169

\begin{tabular}{cc}
\hline Componentes & Concentração \\
\hline Meio MEM $^{a}$ & $10 \mathrm{~g} / \mathrm{l}$ \\
Meio Schneider $^{b}$ & $5 \%$ \\
Lactoalbumina $^{c}$ & $1 \mathrm{~g} / \mathrm{l}$ \\
Glicose $^{c}$ & $1 \mathrm{~g} / \mathrm{l}$ \\
Hipoxantina $^{c}$ & $0,5 \mu \mathrm{M}$ \\
Hidroxicortisona $^{c}$ & $1 \mu \mathrm{M}$ \\
Serotonina $^{c}$ & $1 \mu \mathrm{M}$ \\
Triiodotironina $^{c}$ & $0,2 \mu \mathrm{M}$ \\
HEPES $^{c}$ & $25 \mathrm{mM}$ \\
Penicilina $^{d}$ & $200 \mathrm{U} / \mathrm{ml}$ \\
Estreptomicina $^{d}$ & $200 \mu \mathrm{g} / \mathrm{ml}$ \\
Anfotericina B $^{d}$ & $2 \mu \mathrm{g} / \mathrm{ml}$ \\
Soro fetal bovino $^{d}$ & $10 \%$ \\
\hline
\end{tabular}

Meio para cultivo de esquistossômulos, esterilizado por filtração (BASCH, 1981).

a Meio Mínimo Essencial de Eagle (MEM); pó preparado conforme recomendações do fabricante (Cultilab).

${ }^{b}$ Meio em pó preparado conforme recomendações do fabricante (Sigma-Aldrich).

c Sigma-Aldrich.

${ }^{\mathrm{d}}$ Cultilab.

\subsection{Avaliação da atividade de compostos e extratos em adultos e esquistossômulos de Schistosoma mansoni}

\subsubsection{Avaliação da atividade de compostos e extratos em vermes adultos}

As culturas de vermes adultos foram continuamente monitoradas por microscopia ou lupa. Para avaliar a toxicidade dos compostos e extratos sobre o S. mansoni foram considerados os seguintes parâmetros: atividade motora (motilidade), contração muscular, alterações morfológicas no tegumento e a capacidade reprodutiva.

A redução da atividade motora e as alterações morfológicas foram qualitativamente avaliadas como "leve" ou "significativa". No primeiro caso, utilizou-se um estereomicroscópio, enquanto que, no segundo, um microscópio invertido, usando técnica de campo claro ou contraste de interferência (XIAO e CATTO, 1989; XIAO et al., 2007; MAGALHÃES et al., 2009, 2010; PARREIRA et al., 2010; MORAES et al., 2011a, 2011b).

A capacidade reprodutiva de S. mansoni foi avaliada pelo acasalamento e oviposição das fêmeas. Nos ensaios, o número de ovos era contado diariamente com o auxílio de um estereomicroscópio (SANDERSON et al., 2002; MITSUI; MIURA; AOKI, 2009; BRAGUINE et al., 2009; MORAES et al., 2011a, 2011b). 
A mortalidade dos vermes foi julgada pela ausência de movimentos durante 2 minutos ou quando tocados com uma pinça (XIAO e CATTO, 1989; RAMIREZ et al., 2007; KEISER, 2010). No término do período de incubação (5 dias) ou ocorrência de morte, os parasitas foram fixados e analisados em microscopia confocal como descrito no item 3.6.

\subsubsection{Avaliação da atividade de compostos e extratos em esquistossômulos}

As culturas contendo esquistossômulos, de diferentes idades, em presença de compostos e extratos foram diariamente monitoradas em microscópio invertido com técnica de campo claro ou contraste de interferência (RAMIREZ et al., 2007; ABDULLA et al., 2009; KEISER, 2010). A mortalidade dos esquistossômulos de S. mansoni foi julgada pela ausência de movimentos durante 2 minutos (XIAO et al., 2007; XIAO; MEI; JIAO, 2009). A viabilidade dos parasitas também foi avaliada com a adição de azul de tripan $0,2 \%(\mathrm{v} / \mathrm{v})$ às culturas (corante Sigma-Aldrich); nesse caso, após 5 minutos os helmintos foram analisados e os que não incorporaram o corante eram considerados viáveis (HARROP e WILSON, 1993; TALLIMA e EL RIDI, 2008). No término do período de incubação (5 dias após adição do composto ou extrato) ou ocorrência de morte, os helmintos foram fixados e analisados em microscopia confocal como descrito no item 4.6.

\subsection{Análise morfológica no tegumento de adultos e esquistossômulos com microscopia confocal}

O efeito dos compostos e extratos no tegumento de adultos e esquistossômulos de S. mansoni foi monitorado com microscópio confocal de varredura a laser (Laser Scanning Microscopy, LSM 510 META, Carl Zeiss Inc, Standort Göttingen, Vertrieb, Deutschland). Os parasitas foram fixados em solução AFA e monitorados, com captura de imagens, no microscópio usando os filtros de $488 \mathrm{~nm}$ (excitação) e $505 \mathrm{~nm}$ (emissão) como descrito por Moraes et al. (2009, 2011a, 2011b). A solução AFA consiste em uma mistura de ácido acético glacial, formaldeído, etanol (95\%) e água destilada nas proporções, respectivamente (v/v): [2:9:30:59].

Durante a análise microscópica foram capturadas imagens tridimensionais usando o software LSM Image Browser (Zeiss). Os efeitos dos compostos e extratos no tegumento de adultos de S. mansoni foram analisados de forma quantitativa. Neste caso, os tubérculos na superfície dorsal de helmintos machos foram contados em uma área de $20.000 \mu \mathrm{m}^{2}$ utilizando o mesmo software de captura de imagem (Figura 6). Pelo menos três áreas distintas do mesmo parasita foram analisadas e quantificadas (MORAES et al., 2011a, 2011b). 

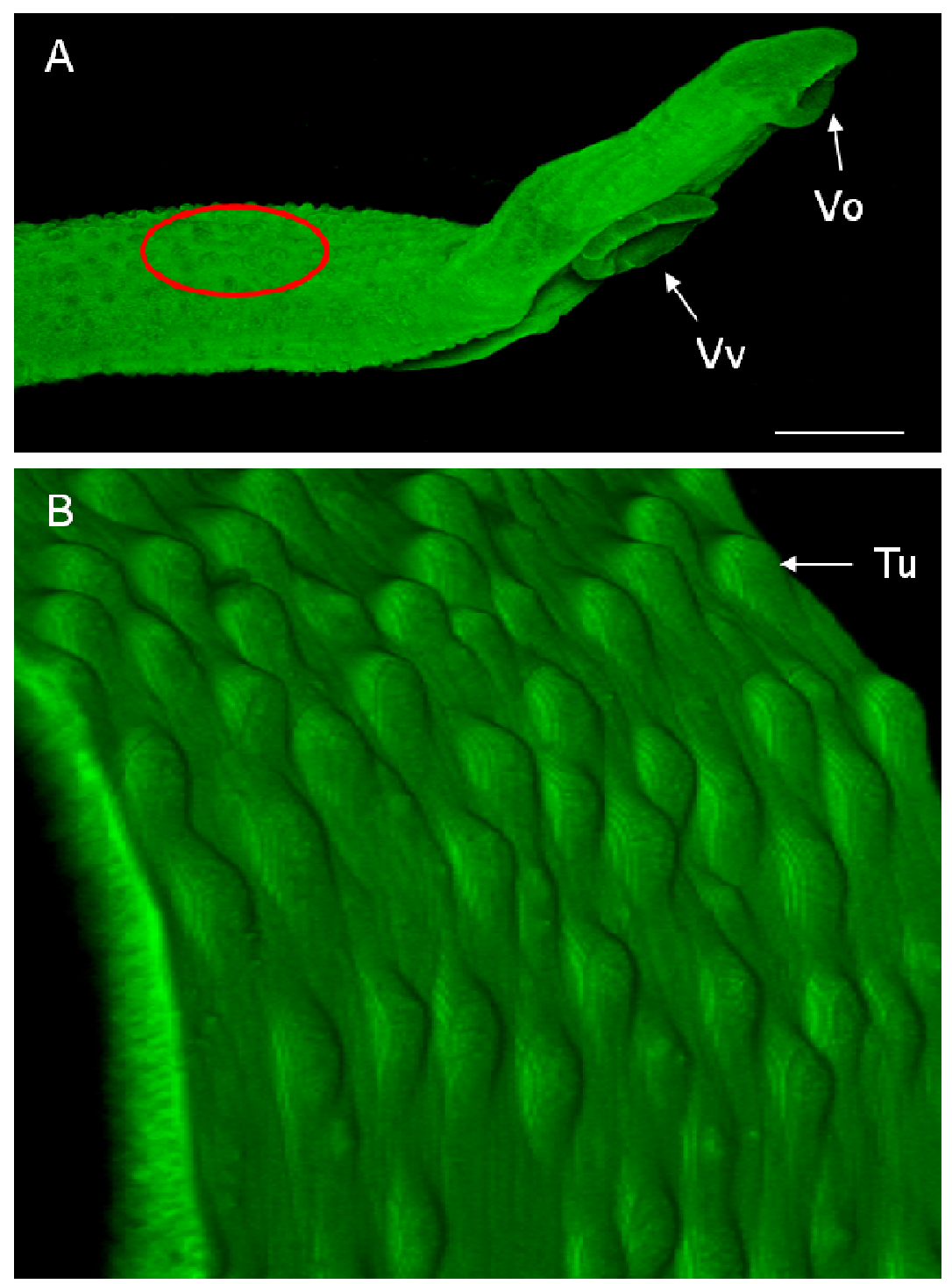

Figura 6. Região dorsal de um macho de Schistosoma mansoni, onde é avaliado, quantitativamente, o efeito de compostos e extratos sobre o tegumento. $O$ parasita mantido em meio RPMI foi fixado em solução AFA após 120 horas. A: visão geral da região anterior do helminto mostrando, em vermelho, o local que é feita a contagem dos tubérculos. Barra $=500 \mu \mathrm{m}$. B: Área de $20.000 \mu \mathrm{m}^{2}$, calculada com o software LSM Image Browser (Zeiss), mostrando os tubérculos; imagem aumentada da região dorsal que está marcada em vermelho na imagem $A$. A e $B$ : imagens tridimensionais, obtidas de microscópio confocal de varredura a laser (LSM 510, META, Zeiss). Em A notar a presença das ventosas oral ( $\mathrm{Vo}$ ) e ventral ( $\mathrm{V} v$ ). Em $\mathrm{B}$ notar os tubérculos (Tu).

\subsection{Cultura de células e ensaios de citotoxicidade}

\subsubsection{Linhagem celular e condições de cultivo}

A linhagem de células de mamífero utilizada nos experimentos realizados neste trabalho foi a de células Vero ATCC CCL-81, procedentes do "American Type Culture Collection" (Manassas, VA, USA), uma linhagem celular de rim de macaco verde africano 
Cercopithecus aethiops (L.). As células foram gentilmente cedidas, na passagem 161, pelo prof. Dr. Ronaldo Z. Mendonça (Laboratório de Parasitologia, Instituto Butantan).

As células Vero foram mantidas a $37{ }^{\circ} \mathrm{C}$, em atmosfera de $\mathrm{CO}_{2}$ a $5 \%$, com repiques realizados a intervalos de 3 a 4 cinco dias, em garrafas plásticas para cultura de células (área de $75 \mathrm{~cm}^{2}$ ), contendo Meio de Eagle Modificado por Dulbecco (DMEM, adquirido na forma líquida pronta para uso; Gibco BRL, Grand Island, NY, USA) suplementado com $10 \%$ de soro fetal bovino. O crescimento era monitorado em microscópio invertido até a formação de monocamadas semiconfluentes, assegurandose, assim, a obtenção de células em fase logarítmica de crescimento. Por serem células aderentes, para a obtenção de suspensão, o sobrenadante das culturas era colhido e as células aderidas eram descoladas em solução tripsina/EDTA 0,05\% (Gibco), procedimento este feito a $37{ }^{\circ} \mathrm{C}$ (tempo aproximado, cinco minutos). A suspensão celular era transferida para tubos de polipropileno de fundo cônico (capacidade de $50 \mathrm{ml}$ ); após centrifugação a $400 \times$ g, por 10 minutos à temperatura ambiente, as células eram ressuspensas em meio DMEM, contadas em câmara de Neubauer e então utilizadas em novos repiques ou distribuídas em microplacas de 96 poços (Nalge Nunc International, Rochester, NY, USA) para os ensaios de citotoxicidade.

\subsubsection{Ensaios de citotoxicidade}

Os ensaios de citotoxicidade foram feitos utilizando o método de coloração por cristal violeta, como descrito por Cruz, Mendonça e Petricevich (2005). Nos experimentos, as células Vero, nas passagens 162 a 171, foram crescidas em placas de cultura de 96 poços (inoculo inicial de $1 \times 10^{5} / \mathrm{ml}$ ). Após 24 horas, com tapetes celulares confluentes, o meio foi removido por aspiração e, em seguida, foi adicionado $200 \mu \mathrm{l}$ de meio DMEM contendo diferentes concentrações de compostos ou extratos em DMSO 0,2\%. A incubação prosseguia a $37{ }^{\circ} \mathrm{C}$ (em atmosfera de $\mathrm{CO}_{2}$ a $5 \%$ ) e, após diferentes tempos, os sobrenadantes eram retirados e as células aderidas foram fixadas e coradas com a adição de $50 \mu \mathrm{l}$ de uma solução que continha cristal violeta $0,2 \%$ em metanol $20 \%(\mathrm{v} / \mathrm{v})$. Após cerca de 10 minutos, o corante foi removido por sucessivas lavagens em água destilada e as microplacas secas à temperatura ambiente.

As células viáveis ficam aderidas nas placas e, portanto, são coradas pelo cristal violeta. Para uma análise mais detalhada da citotoxicidade, adicionou-se 100 ul de etanol 99\% nas microplacas e a eventual toxicidade era avaliada a partir da absorbância de poços controles, contendo células em meio DMEM com DMSO 0,2\%. As absorbâncias foram lidas a $595 \mathrm{~nm}$ em leitor de microplaca (modelo iEMS, Labsystems, Vienna, VA, USA). 


\subsection{Análises gráficas e estatísticas}

Os tratamentos gráficos e análises estatísticas foram realizados com os programas GraphPad Prism versão 5.0 e Excel versão 2007 (Microsoft). As estruturas químicas dos compostos foram feitas com o programa ChemDraw versão Ultra 12.0, cujo software foi gentilmente cedido pela Ms. Leiz M. C. Miura (Núcleo de Pesquisa em Biodiversidade e Biotecnologia, Campus Ministro Reis Velloso, UFPI). A característica anfifílica do peptídeo antimicrobiano dermaseptina foi representada pela projeção Helix-Wheel, um aplicativo Java criado por Edward K. O'Neil e Charles M. Grisham (University of Virginia in Charlottesville, Virginia, EUA). Todas as figuras estão no formato "Tagged Image File" (TIF), com 200 DPI a 300 DPI (pontos por polegada), para melhor resolução no processo de impressão.

A comparação entre os conjuntos experimentais foi feita por análise de variância (ANOVA, "one-way"), aplicando-se o teste de Tukey. Em todos os casos, as diferenças foram consideradas significativas quando a probabilidade de igualdade foi menor que $5 \%$ $(p<0,05)$. 


\section{RESULTADOS E DISCUSSÃO}


5.1 Viabilidade de adultos de Schistosoma mansoni em presença de compostos e extratos 
A viabilidade dos adultos de Schistosoma mansoni foi monitorada, diariamente, utilizando microscópio invertido e estereomicroscópio. Os parâmetros avaliados nesta parte do trabalho foram: a) taxa de mortalidade; b) atividade motora (motilidade). Nos experimentos, os pares de helmintos adultos foram incubados, in vitro, durante cinco dias em placas de 24 poços contendo compostos ou extratos em meio RPMI suplementado com $10 \%$ de soro a $37{ }^{\circ} \mathrm{C}$, em atmosfera de $\mathrm{CO}_{2}$ a $5 \%$. Os compostos (piplartina, piperina, grandisina, epiisopiloturina e dermaseptina) e os extratos etanólicos (Piper tuberculatum, Piper crassinervium, Piper diospyrifolium, Piper fuligineum, Piper gaudichaudianum e Pothomorphe umbellata) utilizados foram diluídos em meio RPMI ou em meio contendo DMSO $0,2 \%$ (concentração final) e então adicionados às culturas previamente a adição de $S$. mansoni. Poços contendo praziquantel $3 \mu \mathrm{g} / \mathrm{ml}$ ou somente meio RPMI com DMSO $0,2 \%$ foram utilizados como controle positivo e negativo, respectivamente.

\subsubsection{Alterações na viabilidade de adultos de Schistosoma mansoni em presença de compostos e extratos}

Todos os compostos e extratos estudados causaram alterações na viabilidade dos vermes adultos. Os compostos e extratos reduziram a motilidade e causaram a morte dos parasitas de forma diretamente dependente da concentração e do tempo de incubação (Figuras 7-17). O monitoramento dos parasitas mantidos em cultura por 24 horas indicou que o efeito esquistossomicida, em todos os adultos de S. mansoni, ocorreu com os compostos piplartina $5 \mu \mathrm{g} / \mathrm{ml}$, dermaseptina $200 \mu \mathrm{g} / \mathrm{ml}$, piperina 950 $\mu \mathrm{g} / \mathrm{ml}$ e grandisina $2000 \mu \mathrm{g} / \mathrm{ml}$; e com os extratos de Piper tuberculatum $10 \mu \mathrm{g} / \mathrm{ml}$, Piper crassinervium $100 \mu \mathrm{g} / \mathrm{ml}$, Piper diospyrifolium $125 \mu \mathrm{g} / \mathrm{ml}$, Piper fuligineum $150 \mu \mathrm{g} / \mathrm{ml}$ Pothomorphe umbellata $150 \mu \mathrm{g} / \mathrm{ml}$ e Piper gaudichaudianum $300 \mu \mathrm{g} / \mathrm{ml}$. No término do período de incubação, isto é, 120 horas, a mortalidade de $100 \%$ foi atingida com os compostos piplartina $3 \mu \mathrm{g} / \mathrm{ml}$, dermaseptina $50 \mu \mathrm{g} / \mathrm{ml}$, epiisopiloturina $150 \mu \mathrm{g} / \mathrm{ml}$, piperina $300 \mu \mathrm{g} / \mathrm{ml}$ e grandisina $900 \mu \mathrm{g} / \mathrm{ml}$; e com os extratos de Piper tuberculatum 4 $\mu \mathrm{g} / \mathrm{ml}$, Piper crassinervium $50 \mu \mathrm{g} / \mathrm{ml}$, Piper diospyrifolium $50 \mu \mathrm{g} / \mathrm{ml}$, Piper fuligineum 50 $\mu \mathrm{g} / \mathrm{ml}$, Pothomorphe umbellata $40 \mu \mathrm{g} / \mathrm{ml}$ e Piper gaudichaudianum $75 \mu \mathrm{g} / \mathrm{ml}$ (Figuras 717). 
$2 \mathrm{~h}$

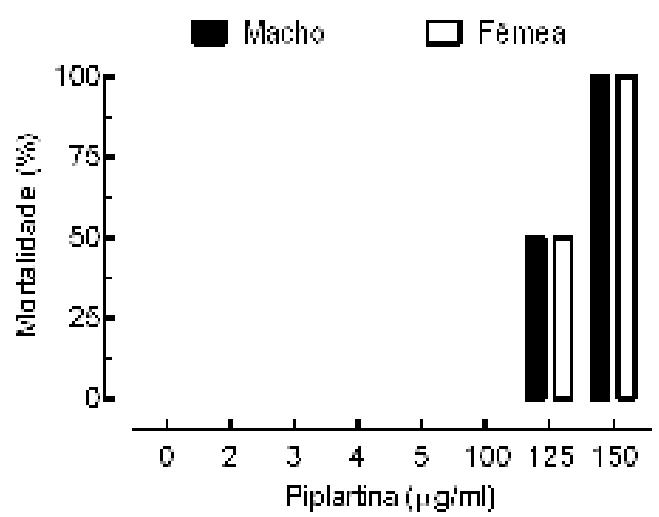

$48 \mathrm{~h}$

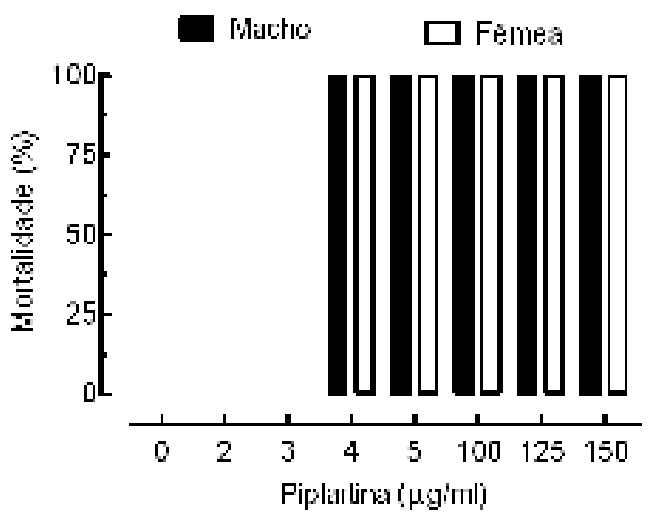

$96 \mathrm{~h}$

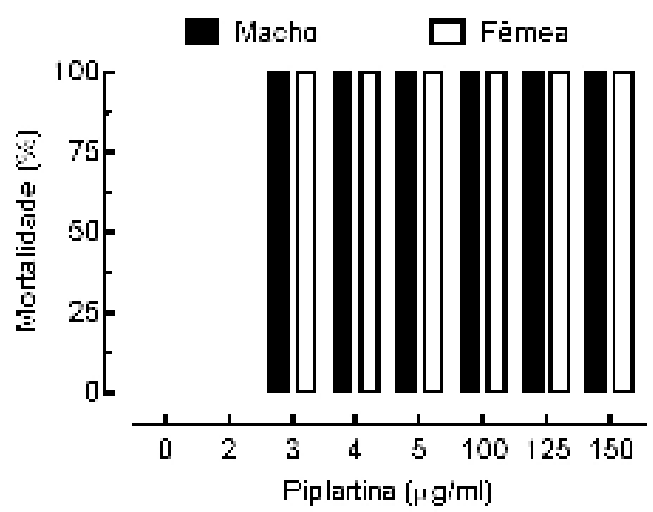

$24 \mathrm{~h}$

Wacha $\square$ Fèmea

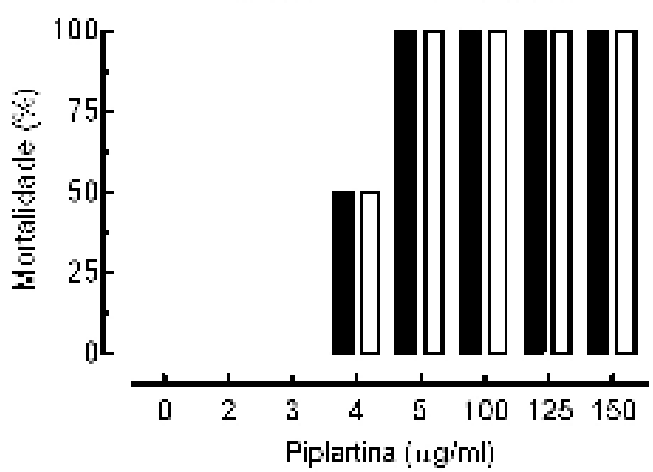

$72 \mathrm{~h}$

Phacho $\square$ Fémea

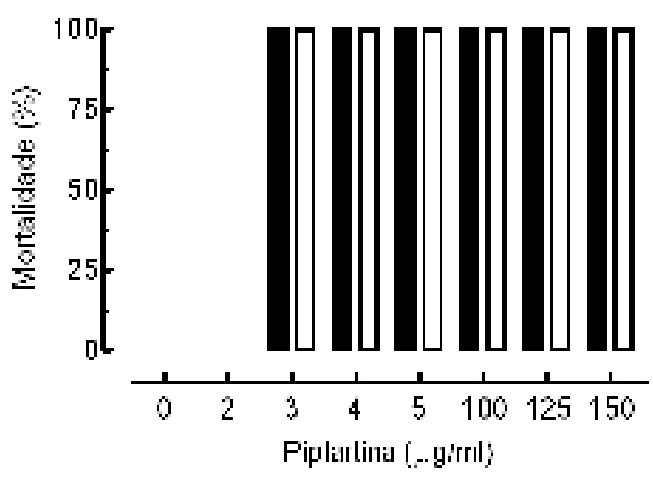

$120 \mathrm{~h}$
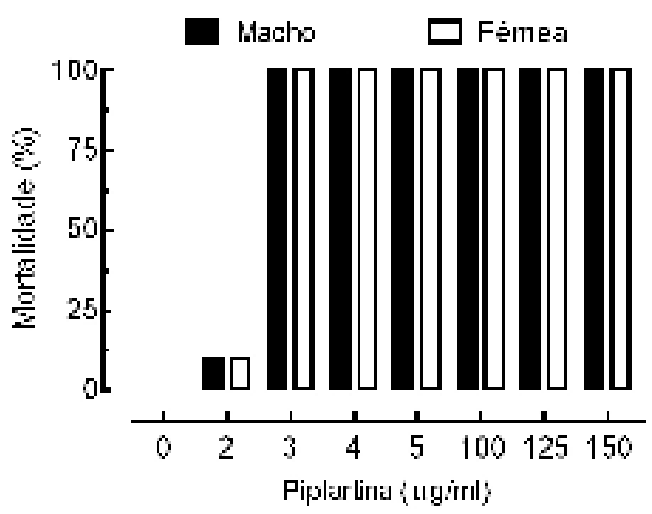

Figura 7. Efeito da amida piplartina na sobrevivência de adultos de Schistosoma mansoni. Os pares de vermes acasalados (machos e fêmeas) foram incubados em meio RPMI contendo diferentes concentrações de piplartina. Os parasitas foram monitorados nos tempos indicados. Os valores são média de 10 casais de vermes no total de três experimentos feitos em triplicatas ou quadruplicatas. 

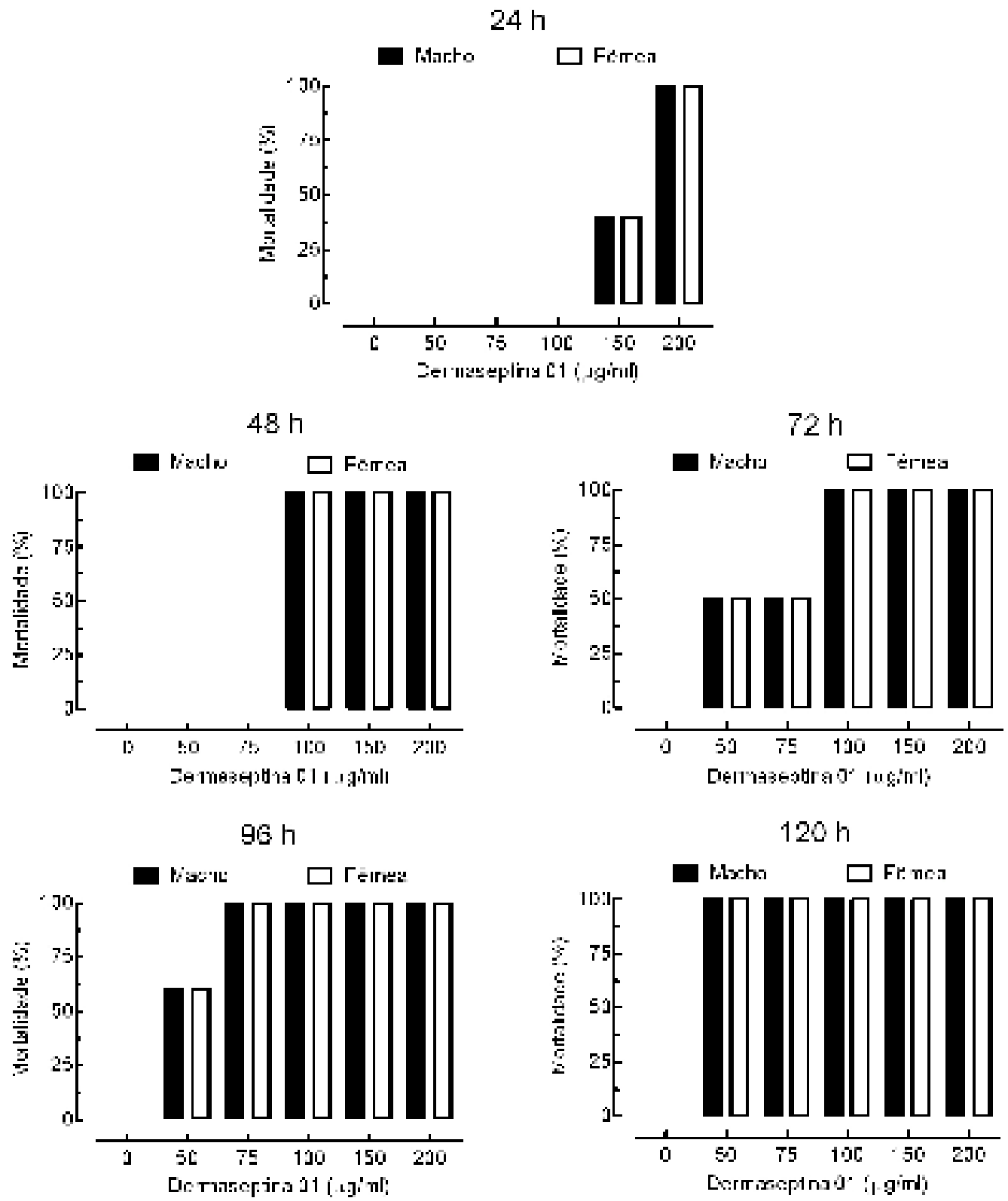

Figura 8. Efeito do peptídeo dermaseptina 01 na sobrevivência de adultos de Schistosoma mansoni. Os pares de vermes acasalados (machos e fêmeas) foram incubados em meio RPMI contendo diferentes concentrações de dermaseptina. Os parasitas foram monitorados nos tempos indicados. Os valores são média de 10 casais de vermes no total de três experimentos feitos em triplicatas ou quadruplicatas. 
$72 \mathrm{~h}$
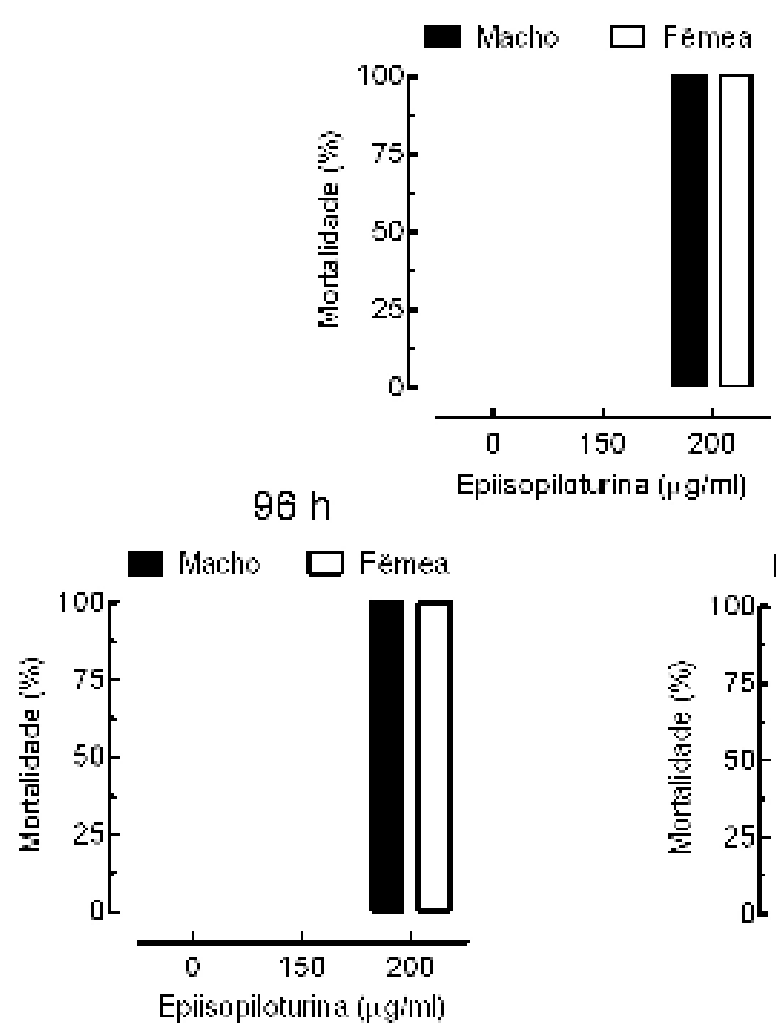

$120 \mathrm{~h}$

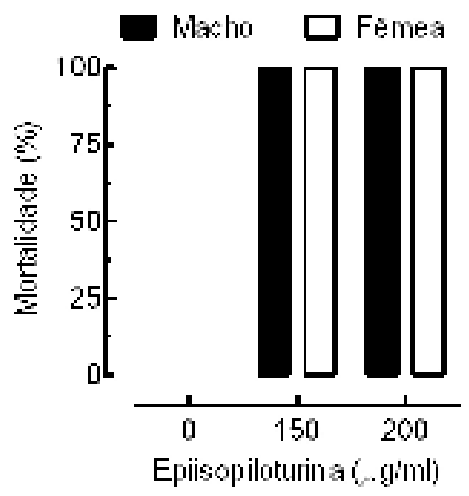

Figura 9. Efeito do alcaloide epiisopiloturina na sobrevivência de adultos de Schistosoma mansoni. Os pares de vermes acasalados (machos e fêmeas) foram incubados em meio RPMI contendo diferentes concentrações de epiisopiloturina. Os parasitas foram monitorados nos tempos indicados. Os valores são média de 9 casais de vermes no total de três experimentos feitos em triplicatas. 
$2 \mathrm{~h}$

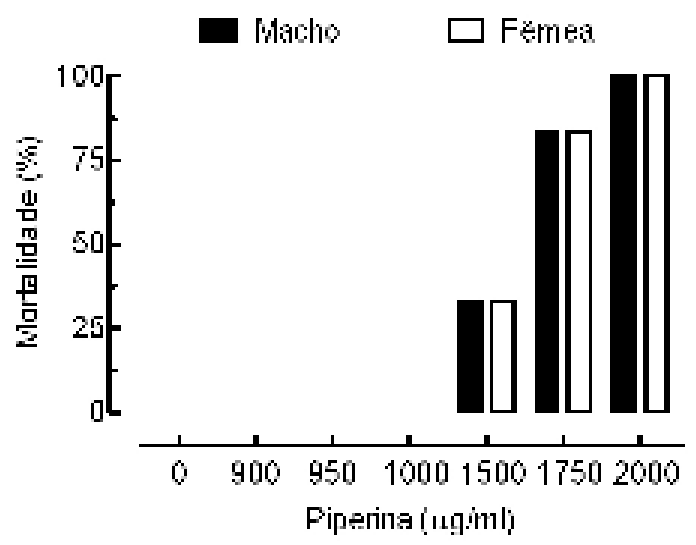

$48 \mathrm{~h}$

Phacho

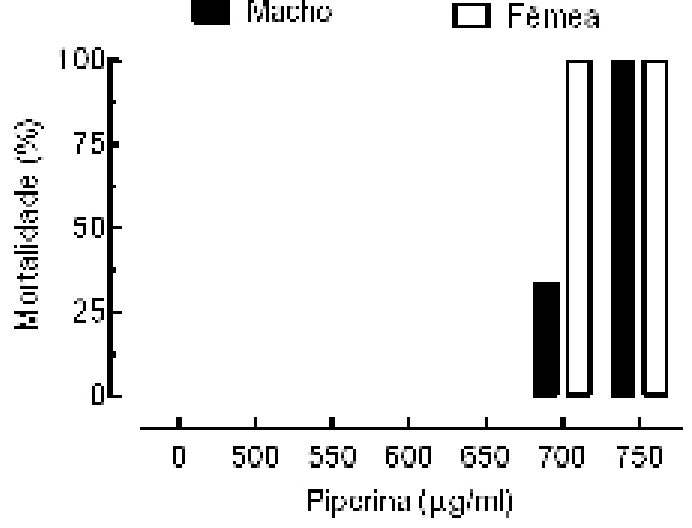

$96 \mathrm{~h}$

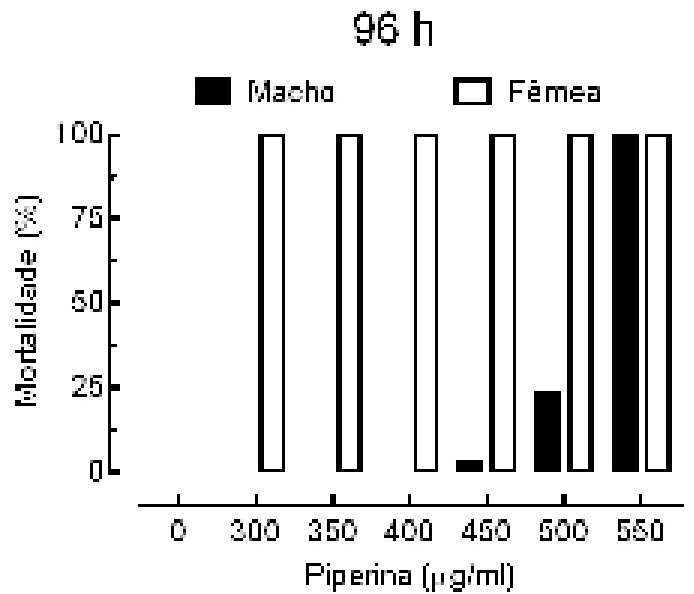

$24 \mathrm{~h}$

Macho $\square$ Fèmea

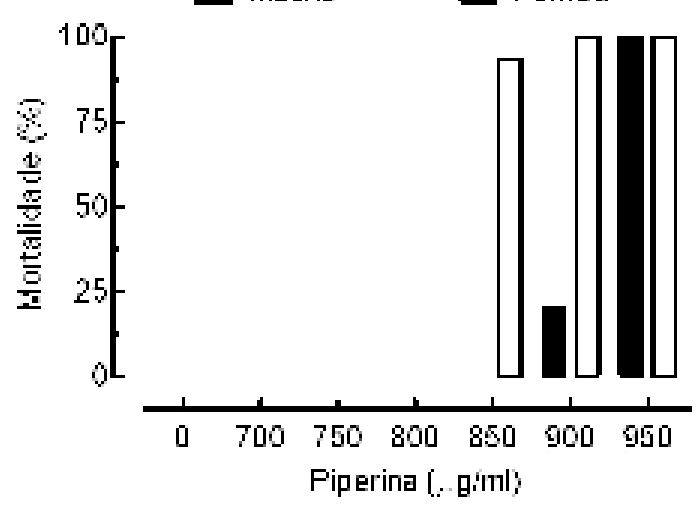

$72 \mathrm{~h}$
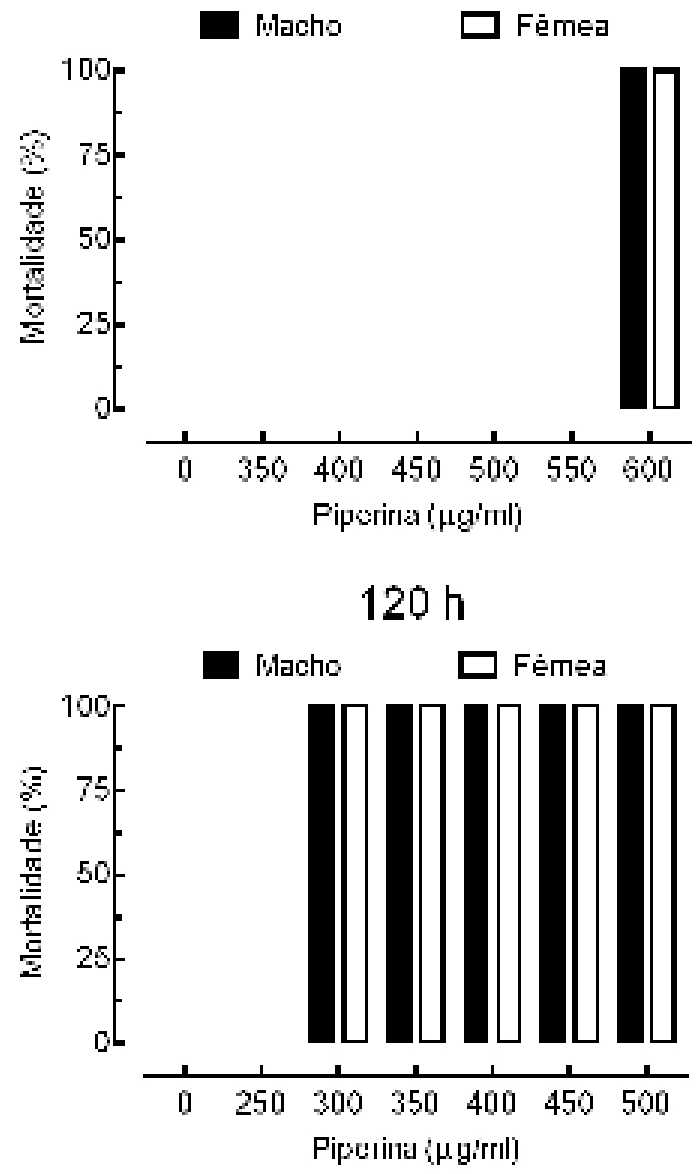

Figura 10. Efeito da amida piperina na sobrevivência de adultos de Schistosoma mansoni. Os pares de vermes acasalados (machos e fêmeas) foram incubados em meio RPMI contendo diferentes concentrações de piperina. Os parasitas foram monitorados nos tempos indicados. Os valores são média de 12 a 15 casais de vermes no total de, pelo menos, três experimentos feitos em triplicatas ou quadruplicatas. 
$24 r_{1}$
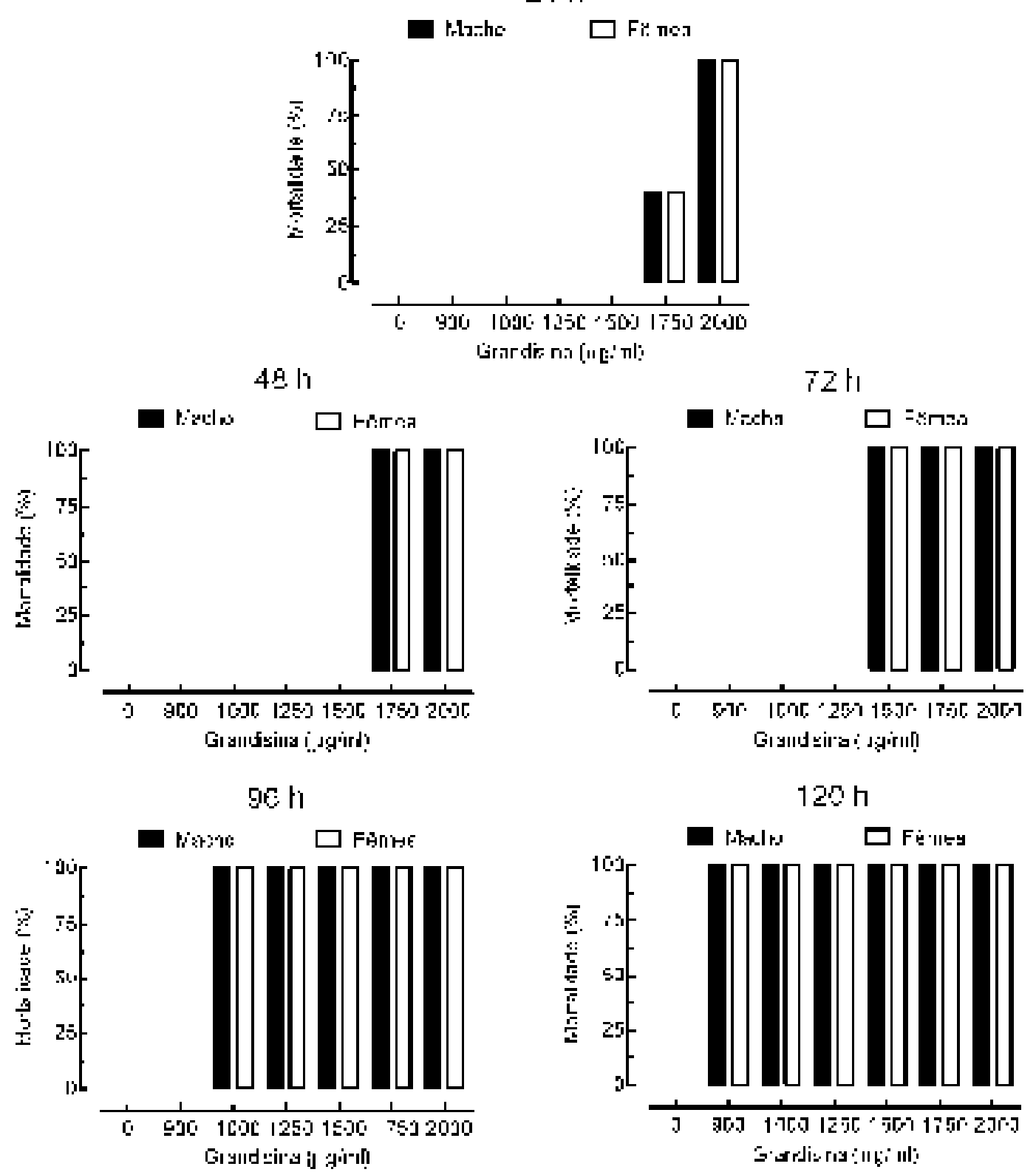

Figura 11. Efeito da lignana grandisina na sobrevivência de adultos de Schistosoma mansoni. Os pares de vermes acasalados (machos e fêmeas) foram incubados em meio RPMI contendo diferentes concentrações de grandisina. Os parasitas foram monitorados nos tempos indicados. Os valores são média de 10 casais de vermes no total de três experimentos feitos em triplicatas ou quadruplicatas. 

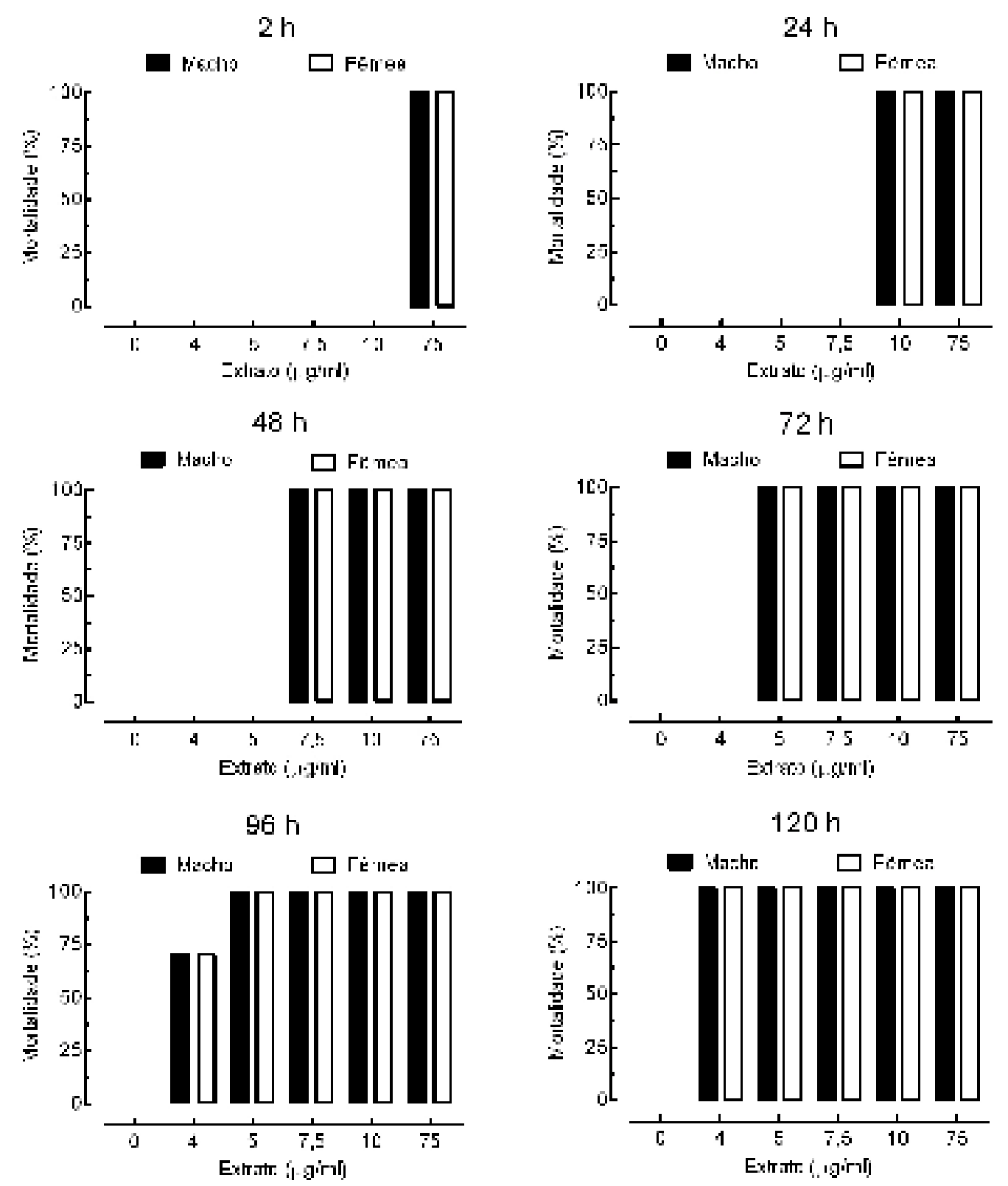

Figura 12. Efeito do extrato de Piper tuberculatum na sobrevivência de adultos de Schistosoma mansoni. Os pares de vermes acasalados (machos e fêmeas) foram incubados em meio RPMI contendo diferentes concentrações do extrato de $P$. tuberculatum. Os parasitas foram monitorados nos tempos indicados. Os valores são média de 10 casais de vermes no total de três experimentos feitos em triplicatas ou quadruplicatas. 
$2 \mathrm{~h}$

vischo

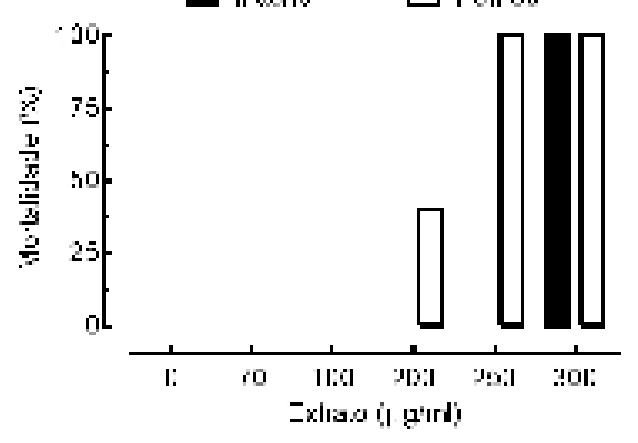

$48 \mathrm{~h}$

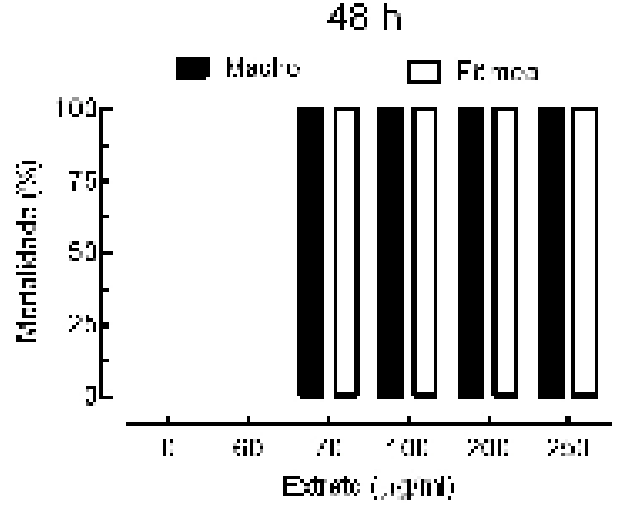

$96 \mathrm{~h}$

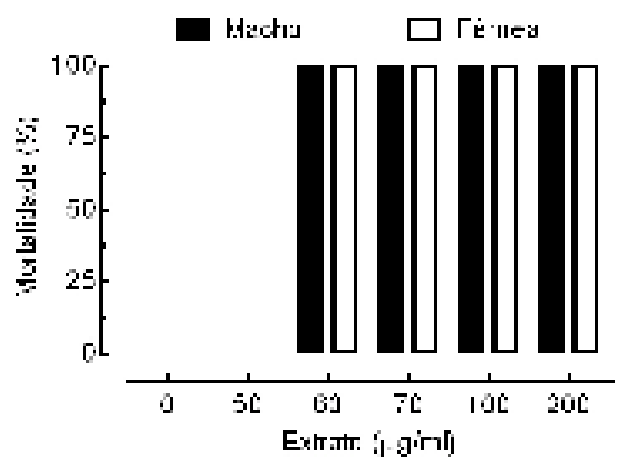

$24 \mathrm{~h}$

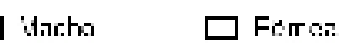

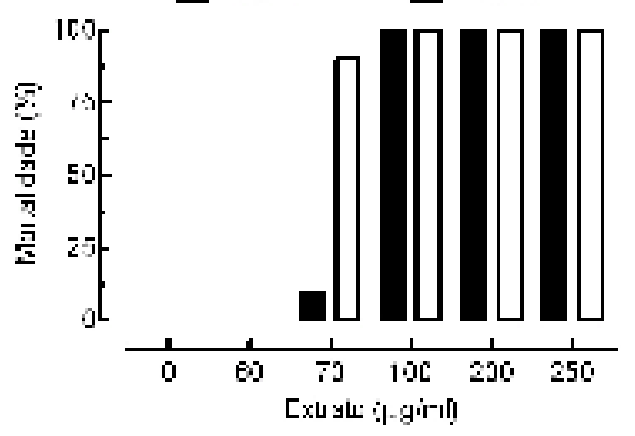

$72 \mathrm{~h}$

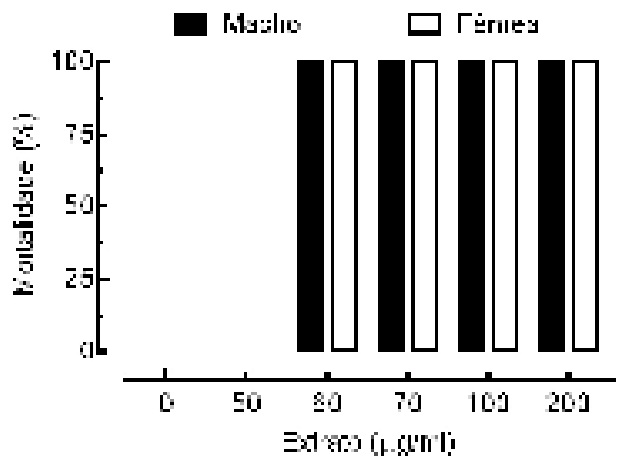

$120 \mathrm{~h}$

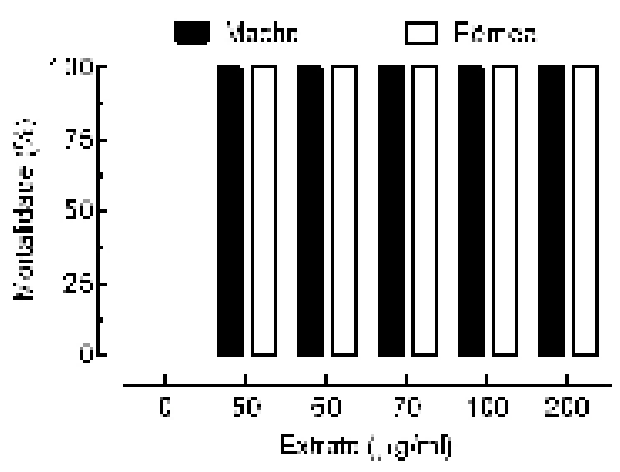

Figura 13. Efeito do extrato de Piper crassinervium na sobrevivência de adultos de Schistosoma mansoni. Os pares de vermes acasalados (machos e fêmeas) foram incubados em meio RPMI contendo diferentes concentrações do extrato de $P$. crassinervium. Os parasitas foram monitorados nos tempos indicados. Os valores são média de 10 casais de vermes no total de três experimentos feitos em triplicatas ou quadruplicatas. 
$2 \mathrm{~h}$

Macho

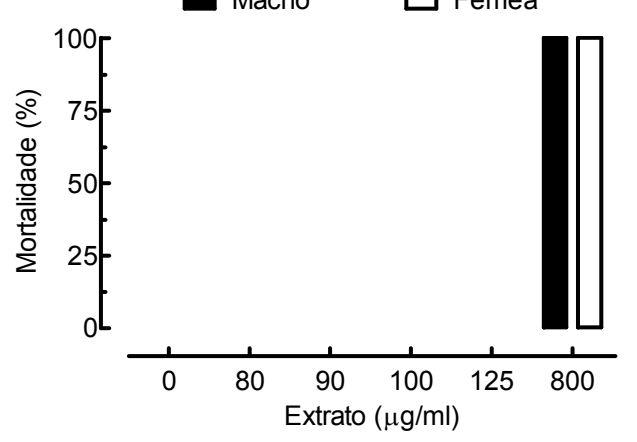

$48 \mathrm{~h}$

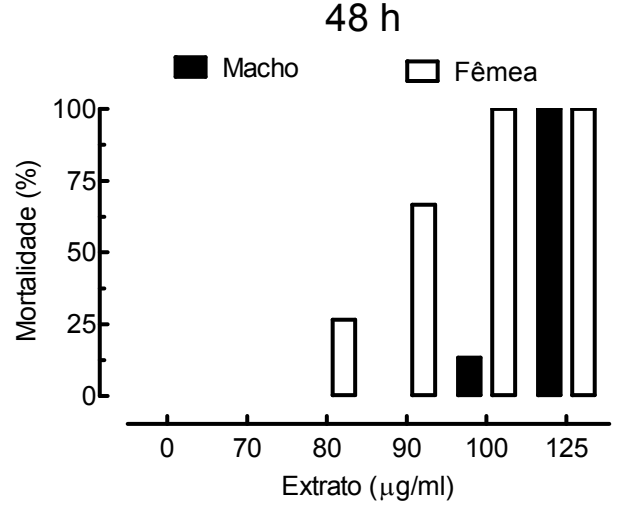

$96 \mathrm{~h}$

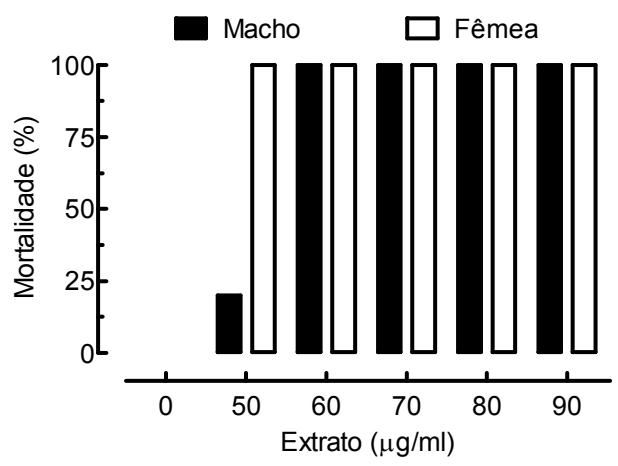

$24 \mathrm{~h}$

Macho $\square$ Fêmea

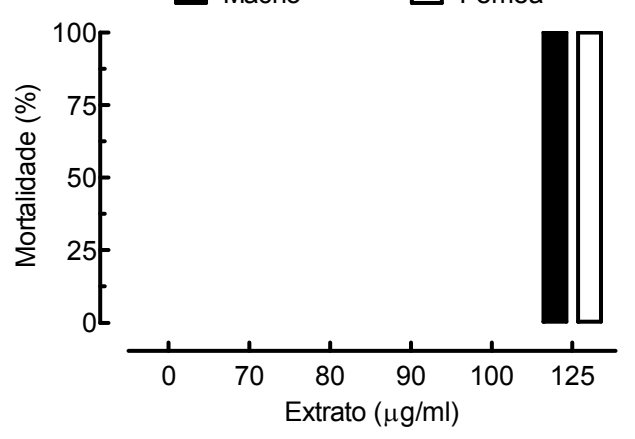

$72 \mathrm{~h}$
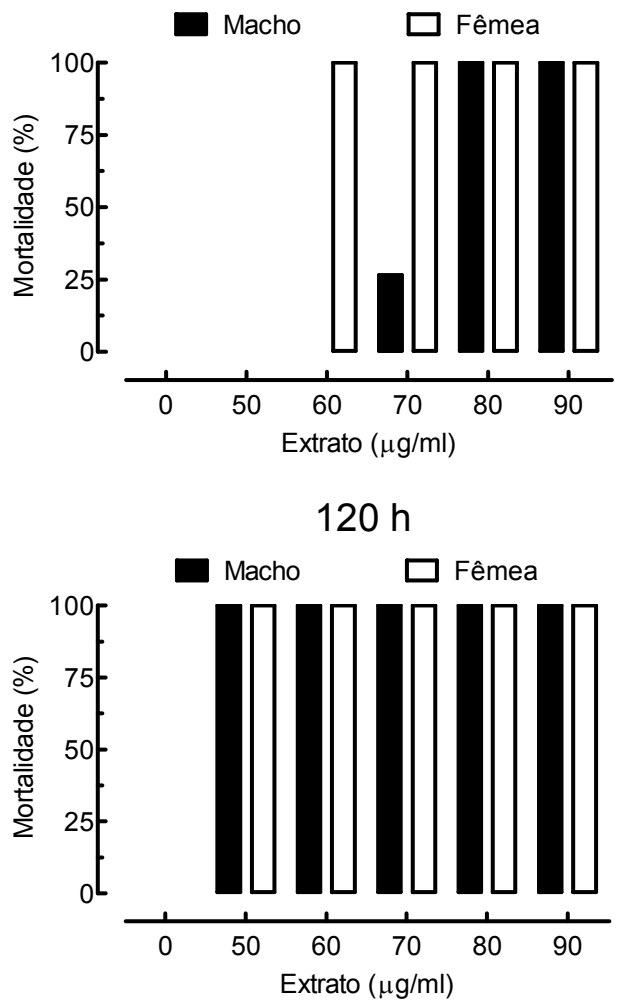

Figura 14. Efeito do extrato de Piper diospyrifolium na sobrevivência de adultos de Schistosoma mansoni. Os pares de vermes acasalados (machos e fêmeas) foram incubados em meio RPMI contendo diferentes concentrações do extrato de $P$. diospyrifolium. Os parasitas foram monitorados nos tempos indicados. Os valores são média de 12 a 15 casais de vermes no total de, pelo menos, três experimentos feitos em triplicatas ou quadruplicatas. 
$2 \mathrm{~h}$

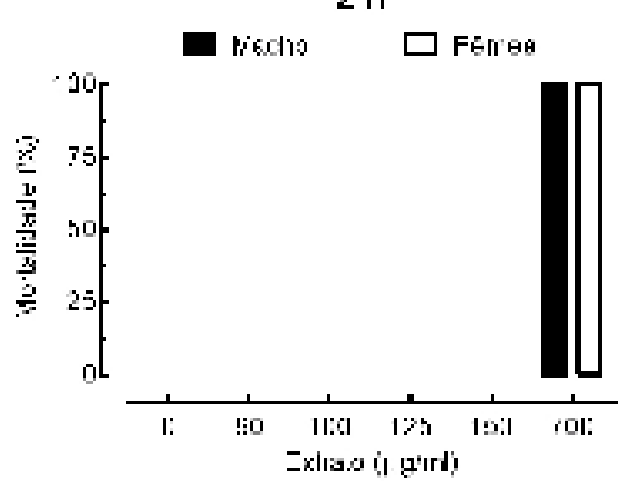

$48 \mathrm{~h}$

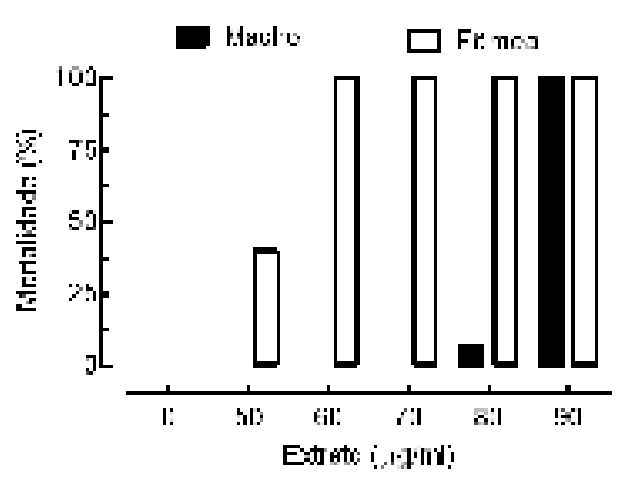

$96 \mathrm{~h}$

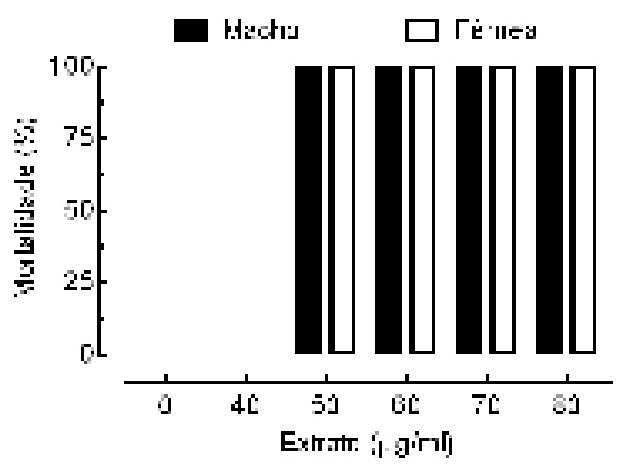

$24 \mathrm{~h}$

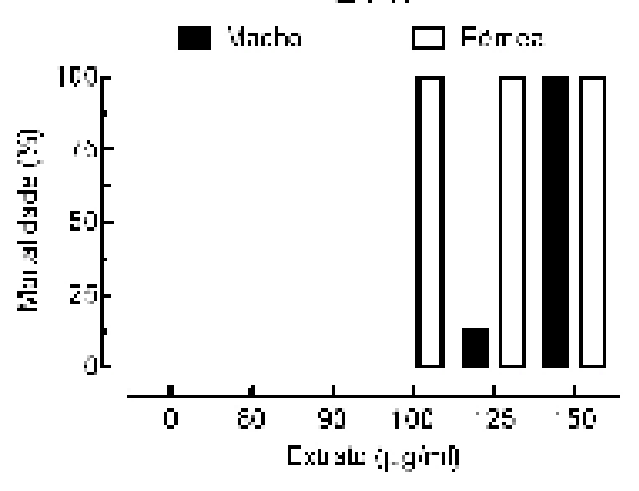

$72 \mathrm{~h}$
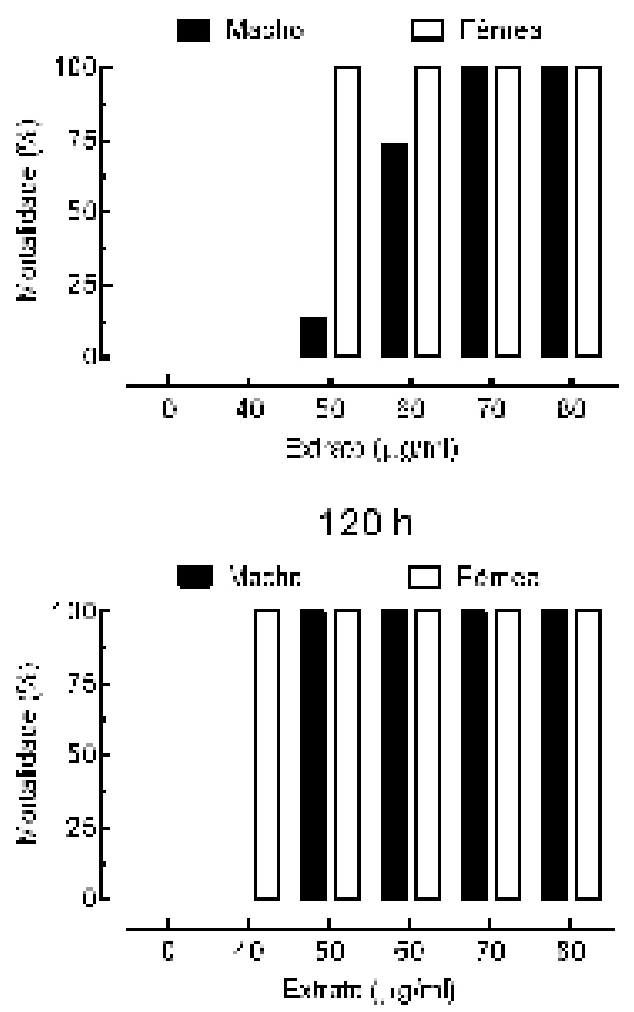

Figura 15. Efeito do extrato de Piper fuligineum na sobrevivência de adultos de Schistosoma mansoni. Os pares de vermes acasalados (machos e fêmeas) foram incubados em meio RPMI contendo diferentes concentrações do extrato de $P$. fuligineum. Os parasitas foram monitorados nos tempos indicados. Os valores são média de 12 a 15 casais de vermes no total de, pelo menos, três experimentos feitos em triplicatas ou quadruplicatas. 
$2 \mathrm{~h}$

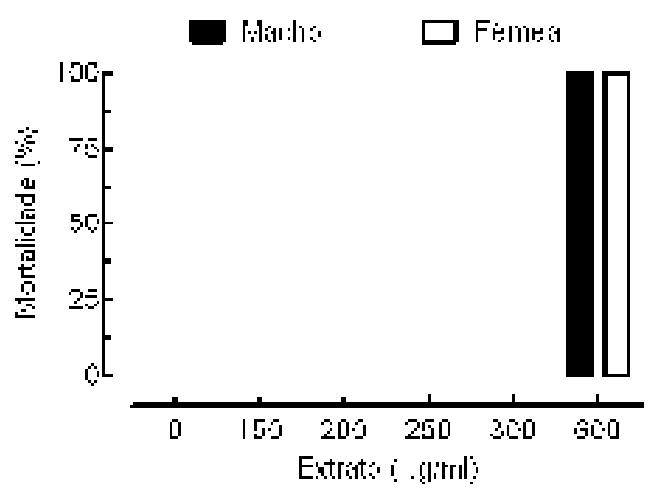

$48 \mathrm{~h}$

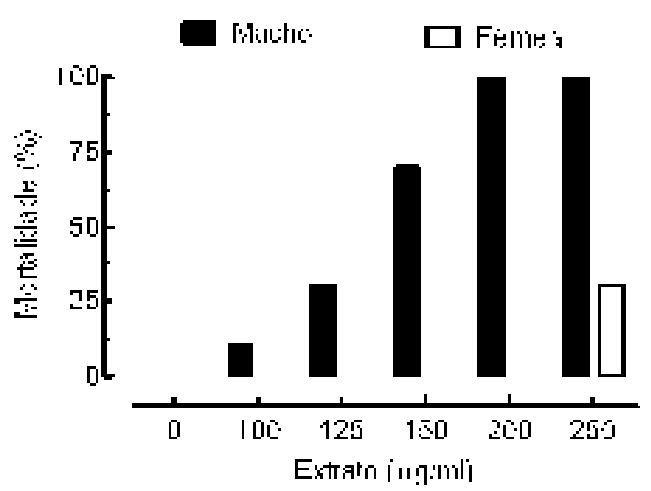

$96 \mathrm{~h}$

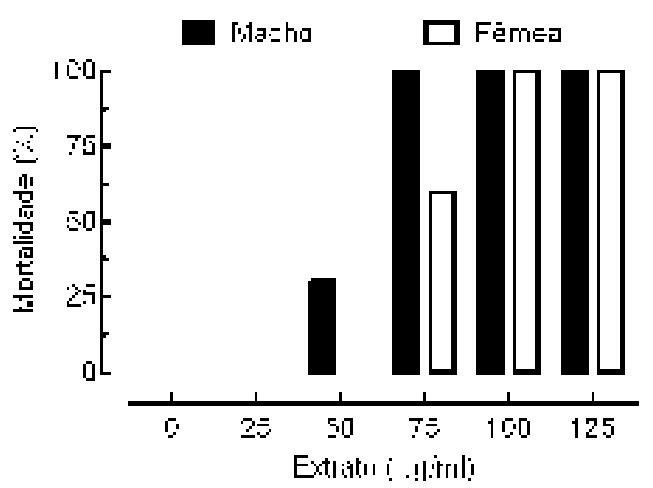

$24 \mathrm{~h}$

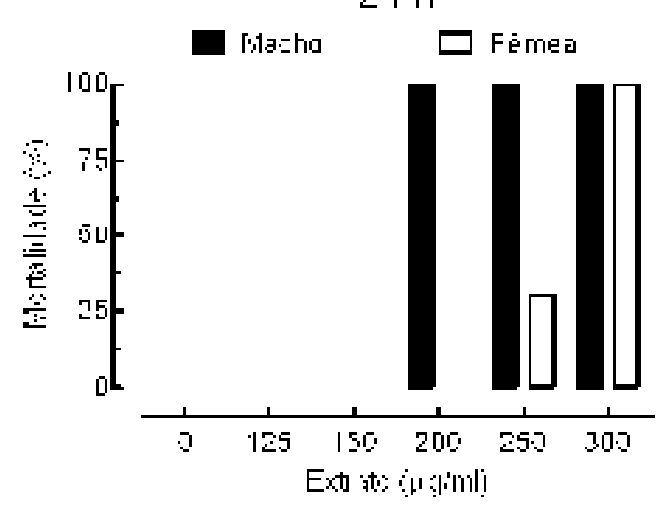

$72 \mathrm{~h}$

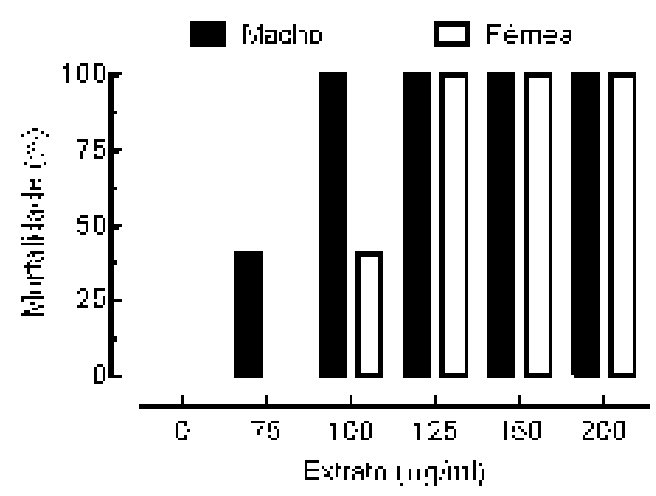

12017

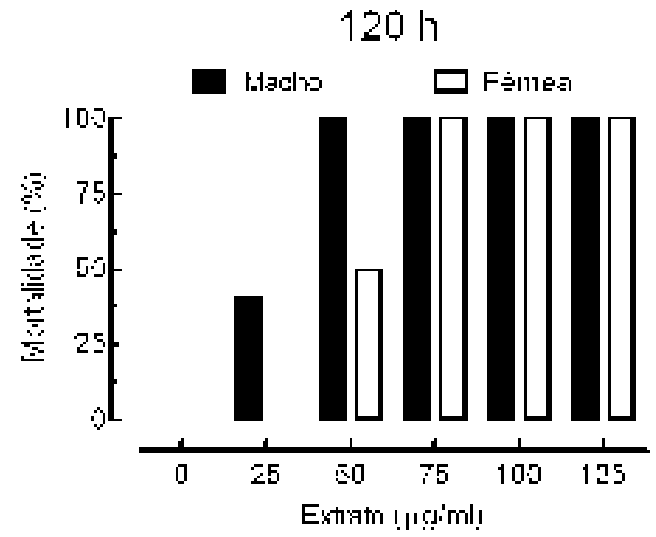

Figura 16. Efeito do extrato de Piper gaudichaudianum na sobrevivência de adultos de Schistosoma mansoni. Os pares de vermes acasalados (machos e fêmeas) foram incubados em meio RPMI contendo diferentes concentrações do extrato de $P$. gaudichaudianum. Os parasitas foram monitorados nos tempos indicados. Os valores são média de 10 casais de vermes no total de três experimentos feitos em triplicatas ou quadruplicatas. 
$2 \mathbf{h}$

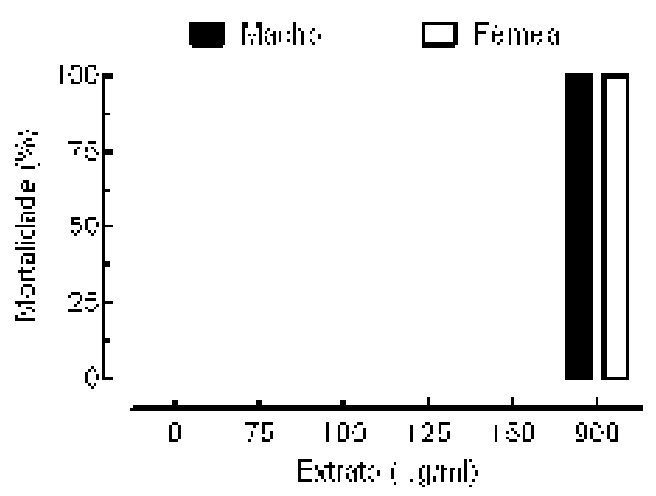

$48 \mathrm{~h}$

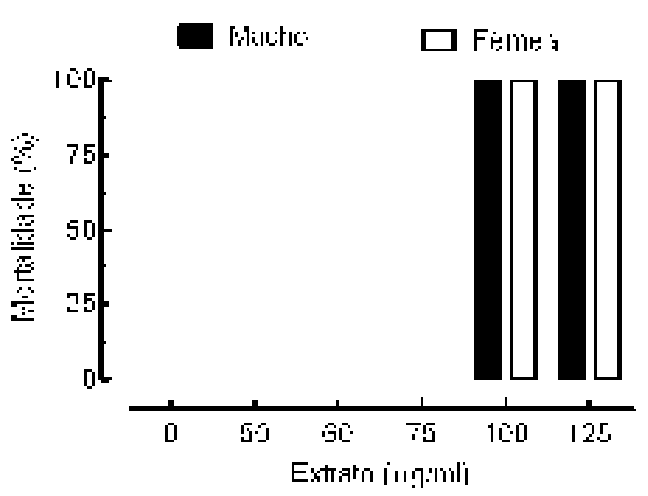

$96 \mathrm{~h}$

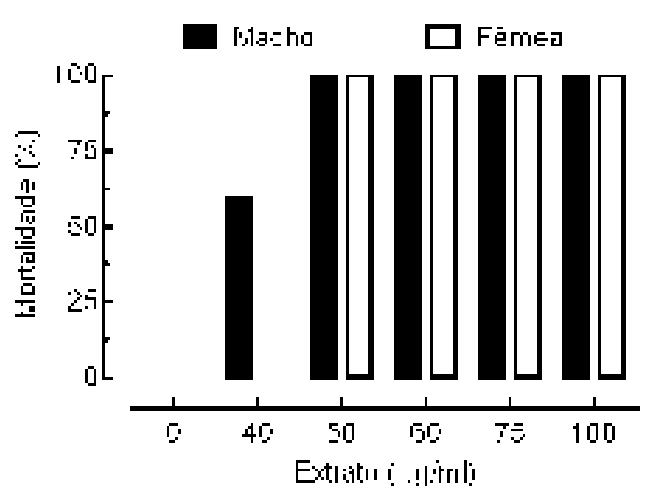

$24 \mathrm{~h}$

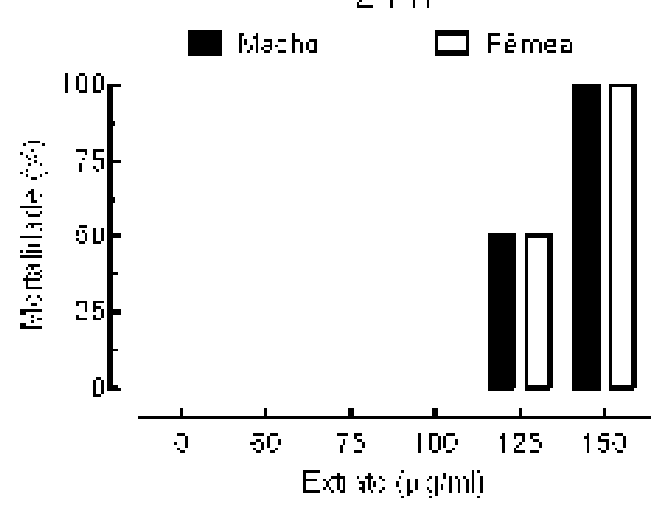

$72 \mathrm{~h}$

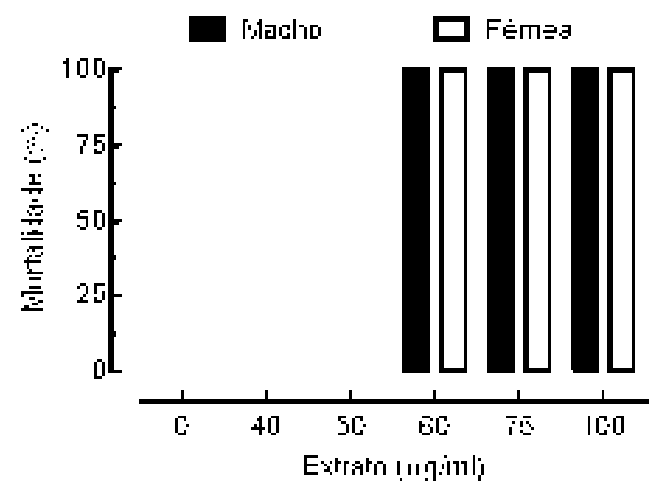

$120 \mathrm{~h}$

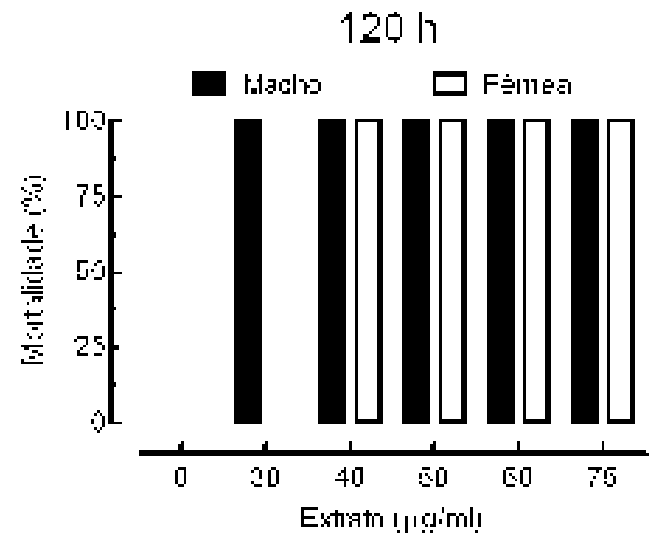

Figura 17. Efeito do extrato de Pothomorphe umbellata na sobrevivência de adultos de Schistosoma mansoni. Os pares de vermes acasalados (machos e fêmeas) foram incubados em meio RPMI contendo diferentes concentrações do extrato de $P$. umbellata. Os parasitas foram monitorados nos tempos indicados. Os valores são média de 10 casais de vermes no total de três experimentos feitos em triplicatas ou quadruplicatas. 
As diferenças na susceptibilidade entre macho e fêmeas de Schistosoma não foram suficientemente investigadas e poucos trabalhos abordam a susceptibilidade ou resistência dos pares de vermes adultos em presença de compostos ou extratos esquistossomicidas. Entre eles, por exemplo, Sanderson et al. (2002) relataram que os helmintos machos são mais susceptíveis que as fêmeas quando em presença de extratos de rizoma de Zingiber officinale Roscoe (Zingiberaceae), um vegetal popularmente conhecido como gengibre ou mangaratá. Além disso, Liang et al. (2001) e Pica-Mattoccia e Ciolli (2004) também mostraram maior mortalidade em parasitas machos durante os estudos com espécimes resistentes e susceptíveis ao praziquantel. Por outro lado, De Araújo et al. (2007) e De Oliveira Penido et al. (2009) assinalaram que os vermes fêmeas são mais susceptíveis que os machos nos experimentos com ácidos $\mathrm{N}$ alquilamino-alcano-tiossulfúricos. Mitsui et al. (2009) também relatam que as fêmeas são mais susceptíveis ao tratamento com artenusato.

Como mostrado nas Figuras 7-17, nos experimentos realizados no presente estudo, notam-se, em alguns casos, diferenças nas taxas de mortalidade entre machos e fêmeas de S. mansoni. As fêmeas são mais susceptíveis a piperina e aos extratos de Piper crassinervium, Piper diospyrifolium e Piper fuligineum; enquanto que os helmintos machos são mais susceptíveis aos extratos de Piper gaudichaudianum e Pothomorphe umbellata. Por outro lado, não houve diferença na taxa de mortalidade entre machos e fêmeas em presença de piplartina, dermaseptina, epiisopiloturina, grandisina e o extrato de Piper tuberculatum.

No geral, considerando as concentrações dos 6 extratos e 5 compostos naturais ensaiados, a análise dos experimentos indicou que os adultos de Schistosoma mansoni são mais susceptíveis a piplartina, dermaseptina e os extratos etanólicos obtidos de folhas de Piper tuberculatum e Pothomorphe umbellata. As concentrações mínimas dos compostos e extratos capazes de matar $100 \%$ dos parasitas estão listadas na Tabela 6 . 
Concentração mínima de compostos e extratos capaz de causar efeito esquistossomicida em $\mathbf{1 0 0} \%$ dos adultos de Schistosoma mansoni

\begin{tabular}{|c|c|c|c|c|}
\hline \multirow{3}{*}{ Compostos/Extratos $^{a}$} & \multicolumn{4}{|c|}{$\begin{array}{c}\text { Concentração mínima capaz de } \\
\text { matar } 100 \% \text { dos parasitas }\end{array}$} \\
\hline & \multicolumn{2}{|c|}{ Machos } & \multicolumn{2}{|c|}{ Fêmeas } \\
\hline & $\mu \mathrm{g} / \mathrm{ml}$ & $\mu \mathrm{M}$ & $\mu \mathrm{g} / \mathrm{ml}$ & $\mu \mathrm{M}$ \\
\hline Piplartina & 3 & 9,45 & 3 & 9,45 \\
\hline Dermaseptina 01 & 50 & 17,89 & 50 & 17,89 \\
\hline Epiisopiloturina & 150 & 524,47 & 150 & 524,47 \\
\hline Piperina & 300 & $1.051,45$ & 300 & $1.051,45$ \\
\hline Grandisina & 900 & $2.080,89$ & 900 & $2.080,89$ \\
\hline Piper tuberculatum & 4 & -- & 4 & -- \\
\hline Pothomorphe umbellata & 30 & -- & 40 & -- \\
\hline Piper fuligineum & 50 & -- & 40 & -- \\
\hline Piper crassinervium & 50 & -- & 50 & -- \\
\hline Piper diospyrifolium & 50 & -- & 50 & -- \\
\hline Piper gaudichaudianum & 50 & -- & 75 & -- \\
\hline$P Z Q^{b}$ & 3 & 9,60 & 3 & 9,60 \\
\hline
\end{tabular}

Os pares de adultos de $S$. mansoni foram incubados no meio RPMI contendo diferentes concentrações de extratos ou compostos. Os parasitas foram monitorados diariamente por até 5 dias.

a Em DMSO 0,2\% no meio RPMI; exceção ao peptídeo dermaseptina 01 no qual foi dissolvido direto no meio RPMI.

${ }^{b}$ Controle positivo: Praziquantel (PZQ).

Os valores correspondem a, pelo menos, três experimentos independentes feitos em triplicatas.

Em todos os ensaios para avaliar a toxicidade de compostos e extratos em $S$. mansoni, a concentração final do DMSO foi $0,2 \%(\mathrm{v} / \mathrm{v})$. A concentração de DMSO empregada na maioria dos estudos in vitro é entre 0,2\% e $2 \%$ (PICA-MATTOCCIA e Cioli, 2004; RAMIREZ et al., 2007; ABDULLA et al., 2009; XIAO et al., 2009; MANNECK et al., 2010). Entretanto, alguns estudos in vitro utilizam concentrações altas de DMSO como, por exemplo, 10\% (BRAGUINE et al., 2009; MAGALHÃES et al., 2009, 2010; PARREIRA et al., 2010). No presente estudo, em todos os experimentos foram realizados dois controles simultaneamente: um com DMSO 0,2\% e, outro, sem o solvente. Em todos os casos, não houve diferenças entre os grupos tratados ou não com DMSO 0,2\%, evidenciando que a concentração do solvente usada neste estudo não afeta a viabilidade dos parasitas. Cabe salientar, ainda, que essas considerações em relação ao uso do DMSO servem para todos os experimentos feitos com adultos e esquistossômulos de $S$. mansoni, cujos resultados serão mostrados adiante. 


\subsubsection{Efeito de compostos e extratos na atividade motora e no acasalamento de adultos de Schistosoma mansoni}

Os esquistosomas adultos, principalmente os machos, apresentam uma variedade de movimento entre os quais, rápidos encurtamento e prolongamento do corpo, movimentos ondulatórios e ondas peristálticas ao longo do corpo, parcial ou de uma extremidade a outra (DA SILVA e NOEL, 1995). A motilidade do parasita, e o efeito de substâncias sobre essa atividade, baseiam-se, principalmente, na observação visual. A análise macroscópica da atividade motora apresenta a vantagem de ser um método simples, direto, de baixo custo e facilidade operacional (NOËL, 2008).

No presente estudo, a atividade motora de $S$. mansoni, baseada na observação macroscópica e microscópica dos vermes, foi diariamente monitorada e qualitativamente definida como "leve" ou "significativa". Apesar de subjetivo, esse critério qualitativo é comumente empregado nos ensaios in vitro (XIAO et al., 2007; MAGALHÃES et al., 2009, 2010; PARREIRA et al., 2010; MORAES et al., 2011a, 2011b). Nos experimentos realizados neste estudo, comparativamente aos helmintos incubados apenas em meio de cultura, a motilidade dos parasitas foi significativamente reduzida com piplartina $2 \mu \mathrm{g} / \mathrm{ml}$, dermaseptina $50 \mu \mathrm{g} / \mathrm{ml}$, epiisopiloturina $75 \mu \mathrm{g} / \mathrm{ml}$ piperina $300 \mu \mathrm{g} / \mathrm{ml}$ e grandisina 900 $\mu \mathrm{g} / \mathrm{ml}$; e com os extratos de Piper tuberculatum $4 \mu \mathrm{g} / \mathrm{ml}$, Piper crassinervium $50 \mu \mathrm{g} / \mathrm{ml}$, Piper diospyrifolium $50 \mu \mathrm{g} / \mathrm{ml}$, Piper fuligineum $40 \mu \mathrm{g} / \mathrm{ml}$ e Piper gaudichaudianum 25 $\mu \mathrm{g} / \mathrm{ml}$ e Pothomorphe umbellata $40 \mu \mathrm{g} / \mathrm{ml}$. Nas concentrações letais, independentemente do tempo de incubação, notou-se, ainda, que nenhum composto ou extrato induziu contração muscular nos parasitas. Por outro lado, praziquantel $3 \mu \mathrm{g} / \mathrm{ml}$ induziu, nos instantes iniciais, contração dos helmintos e redução na motilidade sem a separação dos pares de adultos de S. mansoni (Tabelas 7-17). 
Tabela 7 - Efeito da amida piplartina na atividade motora e no acasalamento de adultos de Schistosoma mansoni

\begin{tabular}{|c|c|c|c|c|c|}
\hline \multirow{2}{*}{$\begin{array}{l}\text { Piplartina } \\
(\mu g / m \mathrm{l})^{\mathrm{b}}\end{array}$} & \multirow{2}{*}{$\begin{array}{c}\text { Tempo de } \\
\text { incubação } \\
\text { (h) }\end{array}$} & \multirow{2}{*}{$\begin{array}{c}\text { Mortalidade } \\
(\%)^{\mathrm{a}}\end{array}$} & \multirow{2}{*}{$\begin{array}{c}\text { Vermes } \\
\text { separados } \\
(\%)^{\mathrm{a}}\end{array}$} & \multicolumn{2}{|c|}{$\begin{array}{l}\text { Redução na atividade } \\
\text { motora }(\%)^{a}\end{array}$} \\
\hline & & & & Leve & Significativa \\
\hline \multirow[t]{6}{*}{0} & 2 & 0,0 & 0,0 & 0,0 & 0,0 \\
\hline & 24 & 0,0 & 0,0 & 0,0 & 0,0 \\
\hline & 48 & 0,0 & 0,0 & 0,0 & 0,0 \\
\hline & 72 & 0,0 & 0,0 & 0,0 & 0,0 \\
\hline & 96 & 0,0 & 0,0 & 0,0 & 0,0 \\
\hline & 120 & 0,0 & 0,0 & 0,0 & 0,0 \\
\hline \multirow[t]{6}{*}{2} & 2 & 0,0 & 0,0 & 0,0 & 0,0 \\
\hline & 24 & 0,0 & 0,0 & 0,0 & 0,0 \\
\hline & 48 & 0,0 & 0,0 & 0,0 & 0,0 \\
\hline & 72 & 0,0 & 0,0 & 0,0 & 0,0 \\
\hline & 96 & 0,0 & 0,0 & 0,0 & 0,0 \\
\hline & 120 & 10,0 & 0,0 & 0,0 & 10,0 \\
\hline \multirow[t]{6}{*}{3} & 2 & 0,0 & 0,0 & 0,0 & 0,0 \\
\hline & 24 & 0,0 & 100,0 & 30,0 & 0,0 \\
\hline & 48 & 0,0 & 100,0 & 60,0 & 30,0 \\
\hline & 72 & 100,0 & 100,0 & 0,0 & 100,0 \\
\hline & 96 & 100,0 & 100,0 & 0,0 & 100,0 \\
\hline & 120 & 100,0 & 100,0 & 0,0 & 100,0 \\
\hline \multirow[t]{6}{*}{4} & 2 & 0,0 & 0,0 & 0,0 & 0,0 \\
\hline & 24 & 50,0 & 100,0 & 20,0 & 60,0 \\
\hline & 48 & 100,0 & 100,0 & 0,0 & 100,0 \\
\hline & 72 & 100,0 & 100,0 & 0,0 & 100,0 \\
\hline & 96 & 100,0 & 100,0 & 0,0 & 100,0 \\
\hline & 120 & 100,0 & 100,0 & 0,0 & 100,0 \\
\hline \multirow[t]{6}{*}{5} & 2 & 0,0 & 0,0 & 0,0 & 0,0 \\
\hline & 24 & 100,0 & 100,0 & 0,0 & 100,0 \\
\hline & 48 & 100,0 & 100,0 & 0,0 & 100,0 \\
\hline & 72 & 100,0 & 100,0 & 0,0 & 100,0 \\
\hline & 96 & 100,0 & 100,0 & 0,0 & 100,0 \\
\hline & 120 & 100,0 & 100,0 & 0,0 & 100,0 \\
\hline \multirow[t]{6}{*}{150} & 2 & 100,0 & 100,0 & 0,0 & 100,0 \\
\hline & 24 & 100,0 & 100,0 & 0,0 & 100,0 \\
\hline & 48 & 100,0 & 100,0 & 0,0 & 100,0 \\
\hline & 72 & 100,0 & 100,0 & 0,0 & 100,0 \\
\hline & 96 & 100,0 & 100,0 & 0,0 & 100,0 \\
\hline & 120 & 100,0 & 100,0 & 0,0 & 100,0 \\
\hline \multirow[t]{2}{*}{$\mathbf{P Z Q}^{\mathbf{b}, \mathbf{c}}$} & 2 & 100,0 & 0,0 & 0,0 & 100,0 \\
\hline & 24 & 100,0 & 0,0 & 0,0 & 100,0 \\
\hline
\end{tabular}

a Porcentagem em relação a 20 vermes.

${ }^{\mathrm{b}}$ Em DMSO 0,2\% no meio RPMI.

${ }^{c}$ Controle positivo: Praziquantel (PZQ $3 \mu \mathrm{g} / \mathrm{ml}$ ).

A atividade motora foi monitorada em estereomicroscópio e avaliada qualitativamente. Os valores correspondem a três experimentos feitos em triplicatas ou quadruplicatas. 
Tabela 8 - Efeito do peptídeo dermaseptina 01 na atividade motora e no acasalamento de adultos de Schistosoma mansoni

\begin{tabular}{|c|c|c|c|c|c|}
\hline \multirow{2}{*}{$\begin{array}{l}\text { Dermaseptina } \\
\qquad(\mu \mathrm{g} / \mathrm{ml})\end{array}$} & \multirow{2}{*}{$\begin{array}{c}\text { Tempo de } \\
\text { incubaçãa } \\
\text { (h) }\end{array}$} & \multirow{2}{*}{$\begin{array}{c}\text { Mortalidade } \\
(\%)^{a}\end{array}$} & \multirow{2}{*}{$\begin{array}{c}\text { Vermes } \\
\text { separados } \\
(\%)^{\mathrm{a}}\end{array}$} & \multicolumn{2}{|c|}{$\begin{array}{l}\text { Redução na atividade } \\
\text { motora }(\%)^{a}\end{array}$} \\
\hline & & & & Leve & Significativa \\
\hline \multirow[t]{6}{*}{0} & 2 & 0,0 & 0,0 & 0,0 & 0,0 \\
\hline & 24 & 0,0 & 0,0 & 0,0 & 0,0 \\
\hline & 48 & 0,0 & 0,0 & 0,0 & 0,0 \\
\hline & 72 & 0,0 & 0,0 & 0,0 & 0,0 \\
\hline & 96 & 0,0 & 0,0 & 0,0 & 0,0 \\
\hline & 120 & 0,0 & 0,0 & 0,0 & 0,0 \\
\hline \multirow[t]{6}{*}{50} & 2 & 0,0 & 0,0 & 0,0 & 0,0 \\
\hline & 24 & 0,0 & 0,0 & 0,0 & 0,0 \\
\hline & 48 & 0,0 & 0,0 & 50,0 & 0,0 \\
\hline & 72 & 50,0 & 0,0 & 50,0 & 50,0 \\
\hline & 96 & 60,0 & 0,0 & 40,0 & 60,0 \\
\hline & 120 & 100,0 & 0,0 & 0,0 & 100,0 \\
\hline \multirow[t]{6}{*}{75} & 2 & 0,0 & 0,0 & 0,0 & 0,0 \\
\hline & 24 & 0,0 & 0,0 & 0,0 & 0,0 \\
\hline & 48 & 0,0 & 0,0 & 50,0 & 0,0 \\
\hline & 72 & 50,0 & 0,0 & 50,0 & 70,0 \\
\hline & 96 & 100,0 & 0,0 & 0,0 & 100,0 \\
\hline & 120 & 100,0 & 0,0 & 0,0 & 100,0 \\
\hline \multirow[t]{6}{*}{100} & 2 & 0,0 & 0,0 & 0,0 & 0,0 \\
\hline & 24 & 0,0 & 0,0 & 60,0 & 40,0 \\
\hline & 48 & 100,0 & 0,0 & 0,0 & 100,0 \\
\hline & 72 & 100,0 & 0,0 & 0,0 & 100,0 \\
\hline & 96 & 100,0 & 0,0 & 0,0 & 100,0 \\
\hline & 120 & 100,0 & 0,0 & 0,0 & 100,0 \\
\hline \multirow[t]{6}{*}{150} & 2 & 0,0 & 0,0 & 0,0 & 0,0 \\
\hline & 24 & 40,0 & 0,0 & 50,0 & 50,0 \\
\hline & 48 & 100,0 & 0,0 & 0,0 & 100,0 \\
\hline & 72 & 100,0 & 0,0 & 0,0 & 100,0 \\
\hline & 96 & 100,0 & 0,0 & 0,0 & 100,0 \\
\hline & 120 & 100,0 & 0,0 & 0,0 & 100,0 \\
\hline \multirow[t]{6}{*}{200} & 2 & 0,0 & 0,0 & 0,0 & 0,0 \\
\hline & 24 & 100,0 & 0,0 & 0,0 & 100,0 \\
\hline & 48 & 100,0 & 0,0 & 0,0 & 100,0 \\
\hline & 72 & 100,0 & 0,0 & 0,0 & 100,0 \\
\hline & 96 & 100,0 & 0,0 & 0,0 & 100,0 \\
\hline & 120 & 100,0 & 0,0 & 0,0 & 100,0 \\
\hline \multirow[t]{2}{*}{$\mathbf{P Z Q}^{\mathbf{b}}$} & 2 & 100,0 & 0,0 & 0,0 & 100,0 \\
\hline & 24 & 100,0 & 0,0 & 0,0 & 100,0 \\
\hline
\end{tabular}

a Porcentagem em relação a 20 vermes.

${ }^{\mathrm{b}}$ Controle positivo: Praziquantel (PZQ $3 \mu \mathrm{g} / \mathrm{ml}$ ).

A atividade motora foi monitorada em estereomicroscópio e avaliada qualitativamente.

Os valores correspondem a três experimentos feitos em triplicatas ou quadruplicatas. 
Tabela 9 - Efeito do alcaloide epiisopiloturina na atividade motora e no acasalamento de adultos de Schistosoma mansoni

\begin{tabular}{|c|c|c|c|c|c|}
\hline \multirow{2}{*}{$\begin{array}{l}\text { Epiisopiloturina } \\
\qquad(\mu \mathrm{g} / \mathrm{ml})^{\mathrm{b}}\end{array}$} & \multirow{2}{*}{$\begin{array}{c}\text { Tempo de } \\
\text { incubação } \\
\text { (h) }\end{array}$} & \multirow{2}{*}{$\begin{array}{c}\text { Mortalidade } \\
(\%)^{a}\end{array}$} & \multirow{2}{*}{$\begin{array}{c}\text { Vermes } \\
\text { separados } \\
(\%)^{\mathrm{a}}\end{array}$} & \multicolumn{2}{|c|}{$\begin{array}{l}\text { Redução na atividade } \\
\text { motora }(\%)^{a}\end{array}$} \\
\hline & & & & Leve & Significativa \\
\hline \multirow[t]{6}{*}{0} & 2 & 0,0 & 0,0 & 0,0 & 0,0 \\
\hline & 24 & 0,0 & 0,0 & 0,0 & 0,0 \\
\hline & 48 & 0,0 & 0,0 & 0,0 & 0,0 \\
\hline & 72 & 0,0 & 0,0 & 0,0 & 0,0 \\
\hline & 96 & 0,0 & 0,0 & 0,0 & 0,0 \\
\hline & 120 & 0,0 & 0,0 & 0,0 & 0,0 \\
\hline \multirow[t]{6}{*}{75} & 2 & 0,0 & 0,0 & 0,0 & 0,0 \\
\hline & 24 & 0,0 & 0,0 & 0,0 & 0,0 \\
\hline & 48 & 0,0 & 0,0 & 0,0 & 0,0 \\
\hline & 72 & 0,0 & 0,0 & 0,0 & 0,0 \\
\hline & 96 & 0,0 & 0,0 & 0,0 & 0,0 \\
\hline & 120 & 0,0 & 0,0 & 22,2 & 11,1 \\
\hline \multirow[t]{6}{*}{100} & 2 & 0,0 & 0,0 & 0,0 & 0,0 \\
\hline & 24 & 0,0 & 0,0 & 0,0 & 0,0 \\
\hline & 48 & 0,0 & 0,0 & 0,0 & 0,0 \\
\hline & 72 & 0,0 & 0,0 & 22,2 & 0,0 \\
\hline & 96 & 0,0 & 0,0 & 33,3 & 16,6 \\
\hline & 120 & 0,0 & 0,0 & 55,5 & 44,4 \\
\hline \multirow[t]{6}{*}{150} & 2 & 0,0 & 0,0 & 0,0 & 0,0 \\
\hline & 24 & 0,0 & 0,0 & 0,0 & 0,0 \\
\hline & 48 & 0,0 & 0,0 & 33,3 & 22,2 \\
\hline & 72 & 0,0 & 0,0 & 66,6 & 33,3 \\
\hline & 96 & 0,0 & 0,0 & 22,2 & 77,7 \\
\hline & 120 & 100,0 & 0,0 & 0,0 & 100,0 \\
\hline \multirow[t]{6}{*}{200} & 2 & 0,0 & 0,0 & 0,0 & 0,0 \\
\hline & 24 & 0,0 & 0,0 & 44,4 & 0,0 \\
\hline & 48 & 0,0 & 0,0 & 44,4 & 55,5 \\
\hline & 72 & 100,0 & 11,1 & 0,0 & 100,0 \\
\hline & 96 & 100,0 & 11,1 & 0,0 & 100,0 \\
\hline & 120 & 100,0 & 11,1 & 0,0 & 100,0 \\
\hline \multirow[t]{2}{*}{$\mathbf{P Z Q}^{\mathbf{b}, \mathbf{c}}$} & 2 & 100,0 & 0,0 & 0,0 & 100,0 \\
\hline & 24 & 100,0 & 0,0 & 0,0 & 100,0 \\
\hline
\end{tabular}

a Porcentagem em relação a 18 vermes.

b Em DMSO 0,2\% no meio RPMI.

c Controle positivo: Praziquantel (PZQ $3 \mu \mathrm{g} / \mathrm{ml}$ ).

A atividade motora foi monitorada em estereomicroscópio e avaliada qualitativamente.

Os valores correspondem a três experimentos feitos em triplicatas. 
Tabela 10 - Efeito da amida piperina na atividade motora e no acasalamento de adultos de Schistosoma mansoni

\begin{tabular}{|c|c|c|c|c|c|}
\hline \multirow{2}{*}{$\begin{array}{l}\text { Piperina } \\
(\mu g / \mathrm{ml})^{b}\end{array}$} & \multirow{2}{*}{$\begin{array}{c}\text { Tempo de } \\
\text { incubação } \\
\text { (h) }\end{array}$} & \multirow{2}{*}{$\begin{array}{c}\text { Mortalidade } \\
(\%)^{\mathrm{a}}\end{array}$} & \multirow{2}{*}{$\begin{array}{c}\text { Vermes } \\
\text { separados } \\
(\%)^{\mathrm{a}}\end{array}$} & \multicolumn{2}{|c|}{$\begin{array}{c}\text { Redução na atividade } \\
\text { motora }(\%)^{\mathrm{a}}\end{array}$} \\
\hline & & & & Leve & Significativa \\
\hline \multirow[t]{6}{*}{0} & 2 & 0,0 & 0,0 & 0,0 & 0,0 \\
\hline & 24 & 0,0 & 0,0 & 0,0 & 0,0 \\
\hline & 48 & 0,0 & 0,0 & 0,0 & 0,0 \\
\hline & 72 & 0,0 & 0,0 & 0,0 & 0,0 \\
\hline & 96 & 0,0 & 0,0 & 0,0 & 0,0 \\
\hline & 120 & 0,0 & 0,0 & 0,0 & 0,0 \\
\hline \multirow[t]{6}{*}{300} & 2 & 0,0 & 0,0 & 0,0 & 0,0 \\
\hline & 24 & 0,0 & 0,0 & 0,0 & 0,0 \\
\hline & 48 & 0,0 & 0,0 & 0,0 & 0,0 \\
\hline & 72 & 0,0 & 0,0 & 20,0 & 0,0 \\
\hline & 96 & 50,0 & 100,0 & 26,6 & 73,3 \\
\hline & 120 & 100,0 & 100,0 & 0,0 & 100,0 \\
\hline \multirow[t]{6}{*}{400} & 2 & 0,0 & 0,0 & 0,0 & 0,0 \\
\hline & 24 & 0,0 & 0,0 & 0,0 & 0,0 \\
\hline & 48 & 0,0 & 0,0 & 0,0 & 0,0 \\
\hline & 72 & 0,0 & 0,0 & 26,6 & 13,3 \\
\hline & 96 & 50,0 & 100,0 & 13,3 & 86,6 \\
\hline & 120 & 100,0 & 100,0 & 0,0 & 100,0 \\
\hline \multirow[t]{6}{*}{600} & 2 & 0,0 & 0,0 & 0,0 & 0,0 \\
\hline & 24 & 0,0 & 0,0 & 0,0 & 0,0 \\
\hline & 48 & 0,0 & 0,0 & 20,0 & 0,0 \\
\hline & 72 & 100,0 & 100,0 & 0,0 & 100,0 \\
\hline & 96 & 100,0 & 100,0 & 0,0 & 100,0 \\
\hline & 120 & 100,0 & 100,0 & 0,0 & 100,0 \\
\hline \multirow[t]{6}{*}{700} & 2 & 0,0 & 0,0 & 0,0 & 0,0 \\
\hline & 24 & 0,0 & 0,0 & 0,0 & 0,0 \\
\hline & 48 & 66,6 & 100,0 & 6,66 & 93,3 \\
\hline & 72 & 100,0 & 100,0 & 0,0 & 100,0 \\
\hline & 96 & 100,0 & 100,0 & 0,0 & 100,0 \\
\hline & 120 & 100,0 & 100,0 & 0,0 & 100,0 \\
\hline \multirow[t]{6}{*}{950} & 2 & 0,0 & 0,0 & 0,0 & 0,0 \\
\hline & 24 & 100,0 & 100,0 & 0,0 & 100,0 \\
\hline & 48 & 100,0 & 100,0 & 0,0 & 100,0 \\
\hline & 72 & 100,0 & 100,0 & 0,0 & 100,0 \\
\hline & 96 & 100,0 & 100,0 & 0,0 & 100,0 \\
\hline & 120 & 100,0 & 100,0 & 0,0 & 100,0 \\
\hline \multirow[t]{2}{*}{$\mathbf{P Z Q}^{\mathbf{b}, \mathbf{c}}$} & 2 & 100,0 & 0,0 & 0,0 & 100,0 \\
\hline & 24 & 100,0 & 0,0 & 0,0 & 100,0 \\
\hline
\end{tabular}

a Porcentagem em relação a 30 vermes.

${ }^{b}$ Em DMSO 0,2\% no meio RPMI.

c Controle positivo: Praziquantel (PZQ $3 \mu \mathrm{g} / \mathrm{ml}$ ).

A atividade motora foi monitorada em estereomicroscópio e avaliada qualitativamente.

Os valores correspondem a quatro experimentos feitos em triplicatas ou quadruplicatas. 
Tabela 11 - Efeito da lignana grandisina na atividade motora e no acasalamento de adultos de Schistosoma mansoni

\begin{tabular}{|c|c|c|c|c|c|}
\hline \multirow{2}{*}{$\begin{array}{l}\text { Grandisina } \\
(\mu \mathrm{g} / \mathrm{ml})^{\mathrm{b}}\end{array}$} & \multirow{2}{*}{$\begin{array}{c}\text { Tempo de } \\
\text { incubação } \\
\text { (h) }\end{array}$} & \multirow{2}{*}{$\begin{array}{c}\text { Mortalidade } \\
(\%)^{a}\end{array}$} & \multirow{2}{*}{$\begin{array}{c}\text { Vermes } \\
\text { separados } \\
(\%)^{\mathrm{a}}\end{array}$} & \multicolumn{2}{|c|}{$\begin{array}{c}\text { Redução na atividade } \\
\text { motora }(\%)^{a}\end{array}$} \\
\hline & & & & Leve & Significativa \\
\hline \multirow[t]{6}{*}{0} & 2 & 0,0 & 0,0 & 0,0 & 0,0 \\
\hline & 24 & 0,0 & 0,0 & 0,0 & 0,0 \\
\hline & 48 & 0,0 & 0,0 & 0,0 & 0,0 \\
\hline & 72 & 0,0 & 0,0 & 0,0 & 0,0 \\
\hline & 96 & 0,0 & 0,0 & 0,0 & 0,0 \\
\hline & 120 & 0,0 & 0,0 & 0,0 & 0,0 \\
\hline \multirow[t]{6}{*}{900} & 2 & 0,0 & 0,0 & 0,0 & 0,0 \\
\hline & 24 & 0,0 & 0,0 & 0,0 & 0,0 \\
\hline & 48 & 0,0 & 0,0 & 0,0 & 0,0 \\
\hline & 72 & 0,0 & 0,0 & 0,0 & 0,0 \\
\hline & 96 & 0,0 & 0,0 & 60,0 & 0,0 \\
\hline & 120 & 100,0 & 0,0 & 0,0 & 100,0 \\
\hline \multirow[t]{6}{*}{1000} & 2 & 0,0 & 0,0 & 0,0 & 0,0 \\
\hline & 24 & 0,0 & 0,0 & 0,0 & 0,0 \\
\hline & 48 & 0,0 & 0,0 & 0,0 & 0,0 \\
\hline & 72 & 0,0 & 0,0 & 0,0 & 0,0 \\
\hline & 96 & 100,0 & 0,0 & 0,0 & 100,0 \\
\hline & 120 & 100,0 & 0,0 & 0,0 & 100,0 \\
\hline \multirow[t]{6}{*}{1250} & 2 & 0,0 & 0,0 & 0,0 & 0,0 \\
\hline & 24 & 0,0 & 0,0 & 0,0 & 0,0 \\
\hline & 48 & 0,0 & 0,0 & 0,0 & 0,0 \\
\hline & 72 & 0,0 & 0,0 & 40,0 & 20,0 \\
\hline & 96 & 100,0 & 0,0 & 0,0 & 100,0 \\
\hline & 120 & 100,0 & 0,0 & 0,0 & 100,0 \\
\hline \multirow[t]{6}{*}{1500} & 2 & 0,0 & 0,0 & 0,0 & 0,0 \\
\hline & 24 & 0,0 & 0,0 & 0,0 & 0,0 \\
\hline & 48 & 0,0 & 0,0 & 40,0 & 60,0 \\
\hline & 72 & 100,0 & 0,0 & 0,0 & 100,0 \\
\hline & 96 & 100,0 & 0,0 & 0,0 & 100,0 \\
\hline & 120 & 100,0 & 0,0 & 0,0 & 100,0 \\
\hline \multirow[t]{6}{*}{2000} & 2 & 0,0 & 0,0 & 0,0 & 0,0 \\
\hline & 24 & 100,0 & 0,0 & 0,0 & 100,0 \\
\hline & 48 & 100,0 & 0,0 & 0,0 & 100,0 \\
\hline & 72 & 100,0 & 0,0 & 0,0 & 100,0 \\
\hline & 96 & 100,0 & 0,0 & 0,0 & 100,0 \\
\hline & 120 & 100,0 & 0,0 & 0,0 & 100,0 \\
\hline \multirow[t]{2}{*}{$\mathbf{P Z Q}^{\mathbf{b}, \mathbf{c}}$} & 2 & 100,0 & 0,0 & 0,0 & 100,0 \\
\hline & 24 & 100,0 & 0,0 & 0,0 & 100,0 \\
\hline
\end{tabular}

a Porcentagem em relação a 20 vermes.

b Em DMSO 0,2\% no meio RPMI.

${ }^{c}$ Controle positivo: Praziquantel (PZQ $3 \mu \mathrm{g} / \mathrm{ml}$ ).

A atividade motora foi monitorada em estereomicroscópio e avaliada qualitativamente.

Os valores correspondem a três experimentos feitos em triplicatas ou quadruplicatas. 

Tabela 12 - Efeito do extrato de Piper tuberculatum na atividade motora e no
acasalamento de adultos de Schistosoma mansoni

\begin{tabular}{|c|c|c|c|c|c|}
\hline \multirow{2}{*}{$\begin{array}{l}\text { Extrato } \\
(\mu \mathrm{g} / \mathrm{ml})^{b}\end{array}$} & \multirow{2}{*}{$\begin{array}{c}\text { Tempo de } \\
\text { incubaçãa } \\
\text { (h) }\end{array}$} & \multirow{2}{*}{$\begin{array}{c}\text { Mortalidade } \\
(\%)^{a}\end{array}$} & \multirow{2}{*}{$\begin{array}{c}\text { Vermes } \\
\text { separados } \\
(\%)^{\mathrm{a}}\end{array}$} & \multicolumn{2}{|c|}{$\begin{array}{c}\text { Redução na atividade } \\
\text { motora }(\%)^{\mathrm{a}}\end{array}$} \\
\hline & & & & Leve & Significativa \\
\hline \multirow[t]{6}{*}{0} & 2 & 0,0 & 0,0 & 0,0 & 0,0 \\
\hline & 24 & 0,0 & 0,0 & 0,0 & 0,0 \\
\hline & 48 & 0,0 & 0,0 & 0,0 & 0,0 \\
\hline & 72 & 0,0 & 0,0 & 0,0 & 0,0 \\
\hline & 96 & 0,0 & 0,0 & 0,0 & 0,0 \\
\hline & 120 & 0,0 & 0,0 & 0,0 & 0,0 \\
\hline \multirow[t]{6}{*}{4} & 2 & 0,0 & 0,0 & 0,0 & 0,0 \\
\hline & 24 & 0,0 & 0,0 & 0,0 & 0,0 \\
\hline & 48 & 0,0 & 0,0 & 0,0 & 0,0 \\
\hline & 72 & 0,0 & 0,0 & 0,0 & 0,0 \\
\hline & 96 & 70,0 & 100,0 & 30,0 & 100,0 \\
\hline & 120 & 100,0 & 100,0 & 0,0 & 100,0 \\
\hline \multirow[t]{6}{*}{5} & 2 & 0,0 & 0,0 & 0,0 & 0,0 \\
\hline & 24 & 0,0 & 0,0 & 0,0 & 0,0 \\
\hline & 48 & 0,0 & 0,0 & 0,0 & 0,0 \\
\hline & 72 & 100,0 & 100,0 & 0,0 & 100,0 \\
\hline & 96 & 100,0 & 100,0 & 0,0 & 100,0 \\
\hline & 120 & 100,0 & 100,0 & 0,0 & 100,0 \\
\hline \multirow[t]{6}{*}{7,5} & 2 & 0,0 & 0,0 & 0,0 & 0,0 \\
\hline & 24 & 0,0 & 0,0 & 0,0 & 0,0 \\
\hline & 48 & 100,0 & 100,0 & 0,0 & 100,0 \\
\hline & 72 & 100,0 & 100,0 & 0,0 & 100,0 \\
\hline & 96 & 100,0 & 100,0 & 0,0 & 100,0 \\
\hline & 120 & 100,0 & 100,0 & 0,0 & 100,0 \\
\hline \multirow[t]{6}{*}{10} & 2 & 0,0 & 0,0 & 0,0 & 0,0 \\
\hline & 24 & 100,0 & 100,0 & 0,0 & 100,0 \\
\hline & 48 & 100,0 & 100,0 & 0,0 & 100,0 \\
\hline & 72 & 100,0 & 100,0 & 0,0 & 100,0 \\
\hline & 96 & 100,0 & 100,0 & 0,0 & 100,0 \\
\hline & 120 & 100,0 & 100,0 & 0,0 & 100,0 \\
\hline \multirow[t]{6}{*}{75} & 2 & 100,0 & 100,0 & 0,0 & 100,0 \\
\hline & 24 & 100,0 & 100,0 & 0,0 & 100,0 \\
\hline & 48 & 100,0 & 100,0 & 0,0 & 100,0 \\
\hline & 72 & 100,0 & 100,0 & 0,0 & 100,0 \\
\hline & 96 & 100,0 & 100,0 & 0,0 & 100,0 \\
\hline & 120 & 100,0 & 100,0 & 0,0 & 100,0 \\
\hline \multirow[t]{2}{*}{$\mathbf{P Z Q}^{\mathbf{b}, \mathbf{c}}$} & 2 & 100,0 & 0,0 & 0,0 & 100,0 \\
\hline & 24 & 100,0 & 0,0 & 0,0 & 100,0 \\
\hline
\end{tabular}

a Porcentagem em relação a 20 vermes.

${ }^{b}$ Em DMSO 0,2\% no meio RPMI.

${ }^{c}$ Controle positivo: Praziquantel (PZQ $3 \mu \mathrm{g} / \mathrm{ml}$ ).

A atividade motora foi monitorada em estereomicroscópio e avaliada qualitativamente.

Os valores correspondem a três experimentos feitos em triplicatas. 
Tabela 13 - Efeito do extrato de Piper crassinervium na atividade motora e no acasalamento de adultos de Schistosoma mansoni

\begin{tabular}{|c|c|c|c|c|c|}
\hline \multirow{2}{*}{$\begin{array}{l}\text { Extrato } \\
(\mu \mathrm{g} / \mathrm{ml})^{b}\end{array}$} & \multirow{2}{*}{$\begin{array}{c}\text { Tempo de } \\
\text { incubaçãa } \\
\text { (h) }\end{array}$} & \multirow{2}{*}{$\begin{array}{c}\text { Mortalidade } \\
(\%)^{a}\end{array}$} & \multirow{2}{*}{$\begin{array}{c}\text { Vermes } \\
\text { separados } \\
(\%)^{\mathrm{a}}\end{array}$} & \multicolumn{2}{|c|}{$\begin{array}{c}\text { Redução na atividade } \\
\text { motora }(\%)^{\mathrm{a}}\end{array}$} \\
\hline & & & & Leve & Significativa \\
\hline \multirow[t]{6}{*}{0} & 2 & 0,0 & 0,0 & 0,0 & 0,0 \\
\hline & 24 & 0,0 & 0,0 & 0,0 & 0,0 \\
\hline & 48 & 0,0 & 0,0 & 0,0 & 0,0 \\
\hline & 72 & 0,0 & 0,0 & 0,0 & 0,0 \\
\hline & 96 & 0,0 & 0,0 & 0,0 & 0,0 \\
\hline & 120 & 0,0 & 0,0 & 0,0 & 0,0 \\
\hline \multirow[t]{6}{*}{50} & 2 & 0,0 & 0,0 & 0,0 & 0,0 \\
\hline & 24 & 0,0 & 0,0 & 0,0 & 0,0 \\
\hline & 48 & 0,0 & 0,0 & 40,0 & 10,0 \\
\hline & 72 & 0,0 & 0,0 & 30,0 & 70,0 \\
\hline & 96 & 0,0 & 100,0 & 0,0 & 100,0 \\
\hline & 120 & 100,0 & 100,0 & 0,0 & 100,0 \\
\hline \multirow[t]{6}{*}{60} & 2 & 0,0 & 0,0 & 0,0 & 0,0 \\
\hline & 24 & 0,0 & 0,0 & 0,0 & 0,0 \\
\hline & 48 & 0,0 & 0,0 & 0,0 & 0,0 \\
\hline & 72 & 100,0 & 100,0 & 0,0 & 100,0 \\
\hline & 96 & 100,0 & 100,0 & 0,0 & 100,0 \\
\hline & 120 & 100,0 & 100,0 & 0,0 & 100,0 \\
\hline \multirow[t]{6}{*}{70} & 2 & 0,0 & 0,0 & 0,0 & 0,0 \\
\hline & 24 & 50,0 & 100,0 & 0,0 & 80,0 \\
\hline & 48 & 100,0 & 100,0 & 0,0 & 100,0 \\
\hline & 72 & 100,0 & 100,0 & 0,0 & 100,0 \\
\hline & 96 & 100,0 & 100,0 & 0,0 & 100,0 \\
\hline & 120 & 100,0 & 100,0 & 0,0 & 100,0 \\
\hline \multirow[t]{6}{*}{100} & 2 & 0,0 & 0,0 & 0,0 & 0,0 \\
\hline & 24 & 100,0 & 100,0 & 0,0 & 100,0 \\
\hline & 48 & 100,0 & 100,0 & 0,0 & 100,0 \\
\hline & 72 & 100,0 & 100,0 & 0,0 & 100,0 \\
\hline & 96 & 100,0 & 100,0 & 0,0 & 100,0 \\
\hline & 120 & 100,0 & 100,0 & 0,0 & 100,0 \\
\hline \multirow[t]{6}{*}{300} & 2 & 100,0 & 100,0 & 0,0 & 100,0 \\
\hline & 24 & 100,0 & 100,0 & 0,0 & 100,0 \\
\hline & 48 & 100,0 & 100,0 & 0,0 & 100,0 \\
\hline & 72 & 100,0 & 100,0 & 0,0 & 100,0 \\
\hline & 96 & 100,0 & 100,0 & 0,0 & 100,0 \\
\hline & 120 & 100,0 & 100,0 & 0,0 & 100,0 \\
\hline \multirow[t]{2}{*}{$\mathbf{P Z Q}^{\mathrm{b}, \mathrm{c}}$} & 2 & 100,0 & 0,0 & 0,0 & 100,0 \\
\hline & 24 & 100,0 & 0,0 & 0,0 & 100,0 \\
\hline
\end{tabular}

a Porcentagem em relação a 20 vermes.

${ }^{b}$ Em DMSO 0,2\% no meio RPMI.

${ }^{c}$ Controle positivo: Praziquantel (PZQ $3 \mu \mathrm{g} / \mathrm{ml}$ ).

A atividade motora foi monitorada em estereomicroscópio e avaliada qualitativamente.

Os valores correspondem a três experimentos feitos em triplicatas ou quadruplicatas. 

Tabela 14 - Efeito do extrato de Piper diospyrifolium na atividade motora e no
acasalamento de adultos de Schistosoma mansoni

\begin{tabular}{|c|c|c|c|c|c|}
\hline \multirow{2}{*}{$\begin{array}{l}\text { Extrato } \\
(\mu \mathrm{g} / \mathrm{ml})^{b}\end{array}$} & \multirow{2}{*}{$\begin{array}{c}\text { Tempo de } \\
\text { incubaçãa } \\
\text { (h) }\end{array}$} & \multirow{2}{*}{$\begin{array}{c}\text { Mortalidade } \\
(\%)^{a}\end{array}$} & \multirow{2}{*}{$\begin{array}{c}\text { Vermes } \\
\text { separados } \\
(\%)^{\mathrm{a}}\end{array}$} & \multicolumn{2}{|c|}{$\begin{array}{c}\text { Redução na atividade } \\
\text { motora }(\%)^{\mathrm{a}}\end{array}$} \\
\hline & & & & Leve & Significativa \\
\hline \multirow[t]{6}{*}{0} & 2 & 0,0 & 0,0 & 0,0 & 0,0 \\
\hline & 24 & 0,0 & 0,0 & 0,0 & 0,0 \\
\hline & 48 & 0,0 & 0,0 & 0,0 & 0,0 \\
\hline & 72 & 0,0 & 0,0 & 0,0 & 0,0 \\
\hline & 96 & 0,0 & 0,0 & 0,0 & 0,0 \\
\hline & 120 & 0,0 & 0,0 & 0,0 & 0,0 \\
\hline \multirow[t]{6}{*}{50} & 2 & 0,0 & 0,0 & 0,0 & 0,0 \\
\hline & 24 & 0,0 & 0,0 & 0,0 & 0,0 \\
\hline & 48 & 0,0 & 0,0 & 0,0 & 0,0 \\
\hline & 72 & 0,0 & 100,0 & 36,6 & 0,0 \\
\hline & 96 & 60,0 & 100,0 & 16,6 & 83,3 \\
\hline & 120 & 100,0 & 100,0 & 0,0 & 100,0 \\
\hline \multirow[t]{6}{*}{60} & 2 & 0,0 & 0,0 & 0,0 & 0,0 \\
\hline & 24 & 0,0 & 0,0 & 0,0 & 0,0 \\
\hline & 48 & 0,0 & 100,0 & 0,0 & 0,0 \\
\hline & 72 & 50,0 & 100,0 & 40,0 & 60,0 \\
\hline & 96 & 100,0 & 100,0 & 0,0 & 100,0 \\
\hline & 120 & 100,0 & 100,0 & 0,0 & 100,0 \\
\hline \multirow[t]{6}{*}{70} & 2 & 0,0 & 0,0 & 0,0 & 0,0 \\
\hline & 24 & 0,0 & 0,0 & 0,0 & 0,0 \\
\hline & 48 & 0,0 & 100,0 & 6,6 & 0,0 \\
\hline & 72 & 63,3 & 100,0 & 16,6 & 83,3 \\
\hline & 96 & 100,0 & 100,0 & 0,0 & 100,0 \\
\hline & 120 & 100,0 & 100,0 & 0,0 & 100,0 \\
\hline \multirow[t]{6}{*}{80} & 2 & 0,0 & 0,0 & 0,0 & 0,0 \\
\hline & 24 & 0,0 & 100,0 & 0,0 & 0,0 \\
\hline & 48 & 13,3 & 100,0 & 0,0 & 0,0 \\
\hline & 72 & 100,0 & 100,0 & 0,0 & 100,0 \\
\hline & 96 & 100,0 & 100,0 & 0,0 & 100,0 \\
\hline & 120 & 100,0 & 100,0 & 0,0 & 100,0 \\
\hline \multirow[t]{6}{*}{800} & 2 & 100,0 & 100,0 & 0,0 & 100,0 \\
\hline & 24 & 100,0 & 100,0 & 0,0 & 100,0 \\
\hline & 48 & 100,0 & 100,0 & 0,0 & 100,0 \\
\hline & 72 & 100,0 & 100,0 & 0,0 & 100,0 \\
\hline & 96 & 100,0 & 100,0 & 0,0 & 100,0 \\
\hline & 120 & 100,0 & 100,0 & 0,0 & 100,0 \\
\hline \multirow[t]{2}{*}{$\mathbf{P Z Q}^{\mathrm{b}, \mathrm{c}}$} & 2 & 100,0 & 0,0 & 0,0 & 100,0 \\
\hline & 24 & 100,0 & 0,0 & 0,0 & 100,0 \\
\hline
\end{tabular}

a Porcentagem em relação a 30 vermes.

${ }^{b}$ Em DMSO 0,2\% no meio RPMI.

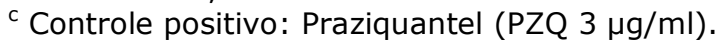

A atividade motora foi monitorada em estereomicroscópio e avaliada qualitativamente.

Os valores correspondem a quatro experimentos feitos em triplicatas ou quadruplicatas. 
Tabela 15 - Efeito do extrato de Piper fuligineum na atividade motora e no acasalamento de adultos de Schistosoma mansoni

\begin{tabular}{|c|c|c|c|c|c|}
\hline \multirow{2}{*}{$\begin{array}{l}\text { Extrato } \\
(\mu \mathrm{g} / \mathrm{ml})^{b}\end{array}$} & \multirow{2}{*}{$\begin{array}{l}\text { Tempo de } \\
\text { incubaçãao } \\
\text { (h) }\end{array}$} & \multirow{2}{*}{$\begin{array}{l}\text { Mortalidade } \\
(\%)^{a}\end{array}$} & \multirow{2}{*}{$\begin{array}{c}\text { Vermes } \\
\text { separados } \\
(\%)^{a}\end{array}$} & \multicolumn{2}{|c|}{$\begin{array}{c}\text { Redução na atividade } \\
\text { motora }(\%)^{a}\end{array}$} \\
\hline & & & & Leve & Significativa \\
\hline \multirow[t]{6}{*}{0} & 2 & 0,0 & 0,0 & 0,0 & 0,0 \\
\hline & 24 & 0,0 & 0,0 & 0,0 & 0,0 \\
\hline & 48 & 0,0 & 0,0 & 0,0 & 0,0 \\
\hline & 72 & 0,0 & 0,0 & 0,0 & 0,0 \\
\hline & 96 & 0,0 & 0,0 & 0,0 & 0,0 \\
\hline & 120 & 0,0 & 0,0 & 0,0 & 0,0 \\
\hline \multirow[t]{6}{*}{40} & 2 & 0,0 & 0,0 & 0,0 & 0,0 \\
\hline & 24 & 0,0 & 0,0 & 0,0 & 0,0 \\
\hline & 48 & 0,0 & 0,0 & 0,0 & 0,0 \\
\hline & 72 & 0,0 & 0,0 & 0,0 & 0,0 \\
\hline & 96 & 0,0 & 0,0 & 0,0 & 0,0 \\
\hline & 120 & 50,0 & 100,0 & 16,6 & 50,0 \\
\hline \multirow[t]{6}{*}{50} & 2 & 0,0 & 0,0 & 0,0 & 0,0 \\
\hline & 24 & 0,0 & 0,0 & 46,6 & 10,0 \\
\hline & 48 & 20,0 & 100,0 & 0,0 & 100,0 \\
\hline & 72 & 56,6 & 100,0 & 0,0 & 100,0 \\
\hline & 96 & 100,0 & 100,0 & 0,0 & 100,0 \\
\hline & 120 & 100,0 & 100,0 & 0,0 & 100,0 \\
\hline \multirow[t]{6}{*}{70} & 2 & 0,0 & 0,0 & 0,0 & 0,0 \\
\hline & 24 & 0,0 & 0,0 & 53,3 & 20,0 \\
\hline & 48 & 50,0 & 100,0 & 0,0 & 100,0 \\
\hline & 72 & 100,0 & 100,0 & 0,0 & 100,0 \\
\hline & 96 & 100,0 & 100,0 & 0,0 & 100,0 \\
\hline & 120 & 100,0 & 100,0 & 0,0 & 100,0 \\
\hline \multirow[t]{6}{*}{80} & 2 & 0,0 & 0,0 & 0,0 & 0,0 \\
\hline & 24 & 0,0 & 0,0 & 60,0 & 20,0 \\
\hline & 48 & 53,3 & 100,0 & 0,0 & 100,0 \\
\hline & 72 & 100,0 & 100,0 & 0,0 & 100,0 \\
\hline & 96 & 100,0 & 100,0 & 0,0 & 100,0 \\
\hline & 120 & 100,0 & 100,0 & 0,0 & 100,0 \\
\hline \multirow[t]{6}{*}{700} & 2 & 100,0 & 0,0 & 0,0 & 100,0 \\
\hline & 24 & 100,0 & 0,0 & 0,0 & 100,0 \\
\hline & 48 & 100,0 & 0,0 & 0,0 & 100,0 \\
\hline & 72 & 100,0 & 0,0 & 0,0 & 100,0 \\
\hline & 96 & 100,0 & 0,0 & 0,0 & 100,0 \\
\hline & 120 & 100,0 & 0,0 & 0,0 & 100,0 \\
\hline \multirow[t]{2}{*}{$\mathbf{P Z Q}^{\mathrm{b}, \mathrm{c}}$} & 2 & 100,0 & 0,0 & 0,0 & 100,0 \\
\hline & 24 & 100,0 & 0,0 & 0,0 & 100,0 \\
\hline
\end{tabular}

a Porcentagem em relação a 30 vermes.

b Em DMSO 0,2\% no meio RPMI.

c Controle positivo: Praziquantel (PZQ $3 \mu \mathrm{g} / \mathrm{ml}$ ).

A atividade motora foi monitorada em estereomicroscópio e avaliada qualitativamente.

Os valores correspondem a quatro experimentos feitos em triplicatas ou quadruplicatas. 
Tabela 16 - Efeito do extrato de Piper gaudichaudianum na atividade motora e no acasalamento de adultos de Schistosoma mansoni

\begin{tabular}{|c|c|c|c|c|c|}
\hline \multirow{2}{*}{$\begin{array}{c}\text { Extrato } \\
(\mu \mathrm{g} / \mathrm{ml})^{b}\end{array}$} & \multirow{2}{*}{$\begin{array}{c}\text { Tempo de } \\
\text { incubação } \\
\text { (h) }\end{array}$} & \multirow{2}{*}{$\begin{array}{c}\text { Mortalidade } \\
(\%)^{\mathrm{a}}\end{array}$} & \multirow{2}{*}{$\begin{array}{c}\text { Vermes } \\
\text { separados } \\
(\%)^{\mathrm{a}}\end{array}$} & \multicolumn{2}{|c|}{$\begin{array}{l}\text { Redução na atividade } \\
\text { motora }(\%)^{a}\end{array}$} \\
\hline & & & & Leve & Significativa \\
\hline \multirow[t]{6}{*}{0} & 2 & 0,0 & 0,0 & 0,0 & 0,0 \\
\hline & 24 & 0,0 & 0,0 & 0,0 & 0,0 \\
\hline & 48 & 0,0 & 0,0 & 0,0 & 0,0 \\
\hline & 72 & 0,0 & 0,0 & 0,0 & 0,0 \\
\hline & 96 & 0,0 & 0,0 & 0,0 & 0,0 \\
\hline & 120 & 0,0 & 0,0 & 0,0 & 0,0 \\
\hline \multirow[t]{6}{*}{25} & 2 & 0,0 & 0,0 & 0,0 & 0,0 \\
\hline & 24 & 0,0 & 0,0 & 0,0 & 0,0 \\
\hline & 48 & 0,0 & 0,0 & 0,0 & 0,0 \\
\hline & 72 & 0,0 & 0,0 & 50,0 & 0,0 \\
\hline & 96 & 0,0 & 0,0 & 80,0 & 20,0 \\
\hline & 120 & 20,0 & 100,0 & 0,0 & 100,0 \\
\hline \multirow[t]{6}{*}{50} & 2 & 0,0 & 0,0 & 0,0 & 0,0 \\
\hline & 24 & 0,0 & 0,0 & 0,0 & 0,0 \\
\hline & 48 & 0,0 & 0,0 & 0,0 & 0,0 \\
\hline & 72 & 0,0 & 0,0 & 50,0 & 5,0 \\
\hline & 96 & 15,0 & 100,0 & 0,0 & 100,0 \\
\hline & 120 & 75,0 & 100,0 & 0,0 & 100,0 \\
\hline \multirow[t]{6}{*}{75} & 2 & 0,0 & 0,0 & 0,0 & 0,0 \\
\hline & 24 & 0,0 & 0,0 & 0,0 & 0,0 \\
\hline & 48 & 0,0 & 0,0 & 0,0 & 0,0 \\
\hline & 72 & 20,0 & 100,0 & 15,0 & 50,0 \\
\hline & 96 & 80,0 & 100,0 & 0,0 & 100,0 \\
\hline & 120 & 100,0 & 100,0 & 0,0 & 100,0 \\
\hline \multirow[t]{6}{*}{100} & 2 & 0,0 & 0,0 & 0,0 & 0,0 \\
\hline & 24 & 0,0 & 0,0 & 0,0 & 0,0 \\
\hline & 48 & 5,0 & 60,0 & 20,0 & 30,0 \\
\hline & 72 & 70,0 & 100,0 & 0,0 & 100,0 \\
\hline & 96 & 100,0 & 100,0 & 0,0 & 100,0 \\
\hline & 120 & 100,0 & 100,0 & 0,0 & 100,0 \\
\hline \multirow[t]{6}{*}{600} & 2 & 100,0 & 0,0 & 0,0 & 100,0 \\
\hline & 24 & 100,0 & 0,0 & 0,0 & 100,0 \\
\hline & 48 & 100,0 & 0,0 & 0,0 & 100,0 \\
\hline & 72 & 100,0 & 0,0 & 0,0 & 100,0 \\
\hline & 96 & 100,0 & 0,0 & 0,0 & 100,0 \\
\hline & 120 & 100,0 & 0,0 & 0,0 & 100,0 \\
\hline \multirow[t]{2}{*}{$\mathbf{P Z Q}^{\mathbf{b}, \mathrm{c}}$} & 2 & 100,0 & 0,0 & 0,0 & 100,0 \\
\hline & 24 & 100,0 & 0,0 & 0,0 & 100,0 \\
\hline
\end{tabular}

a Porcentagem em relação a 20 vermes.

${ }^{\mathrm{b}}$ Em DMSO 0,2\% no meio RPMI.

${ }^{\text {c }}$ Controle positivo: Praziquantel (PZQ $3 \mu \mathrm{g} / \mathrm{ml}$ ).

A atividade motora foi monitorada em estereomicroscópio e avaliada qualitativamente.

Os valores correspondem a três experimentos feitos em triplicatas ou quadruplicatas. 
Tabela 17 - Efeito do extrato de Pothomorphe umbellata na atividade motora e no acasalamento de adultos de Schistosoma mansoni

\begin{tabular}{|c|c|c|c|c|c|}
\hline \multirow{2}{*}{$\begin{array}{c}\text { Extrato } \\
(\mu \mathrm{g} / \mathrm{ml})^{\mathrm{b}}\end{array}$} & \multirow{2}{*}{$\begin{array}{c}\text { Tempo de } \\
\text { incubação } \\
\text { (h) }\end{array}$} & \multirow{2}{*}{$\begin{array}{c}\text { Mortalidade } \\
(\%)^{a}\end{array}$} & \multirow{2}{*}{$\begin{array}{c}\text { Vermes } \\
\text { separados } \\
(\%)^{\mathrm{a}}\end{array}$} & \multicolumn{2}{|c|}{$\begin{array}{c}\text { Redução na atividade } \\
\text { motora }(\%)^{a}\end{array}$} \\
\hline & & & & Leve & Significativa \\
\hline \multirow[t]{6}{*}{0} & 2 & 0,0 & 0,0 & 0,0 & 0,0 \\
\hline & 24 & 0,0 & 0,0 & 0,0 & 0,0 \\
\hline & 48 & 0,0 & 0,0 & 0,0 & 0,0 \\
\hline & 72 & 0,0 & 0,0 & 0,0 & 0,0 \\
\hline & 96 & 0,0 & 0,0 & 0,0 & 0,0 \\
\hline & 120 & 0,0 & 0,0 & 0,0 & 0,0 \\
\hline \multirow[t]{6}{*}{40} & 2 & 0,0 & 0,0 & 0,0 & 0,0 \\
\hline & 24 & 0,0 & 0,0 & 0,0 & 0,0 \\
\hline & 48 & 0,0 & 0,0 & 0,0 & 0,0 \\
\hline & 72 & 0,0 & 0,0 & 0,0 & 0,0 \\
\hline & 96 & 30,0 & 0,0 & 10,0 & 30,0 \\
\hline & 120 & 100,0 & 0,0 & 0,0 & 100,0 \\
\hline \multirow[t]{6}{*}{50} & 2 & 0,0 & 0,0 & 0,0 & 0,0 \\
\hline & 24 & 0,0 & 0,0 & 0,0 & 0,0 \\
\hline & 48 & 0,0 & 0,0 & 0,0 & 0,0 \\
\hline & 72 & 0,0 & 0,0 & 40,0 & 20,0 \\
\hline & 96 & 100,0 & 0,0 & 0,0 & 100,0 \\
\hline & 120 & 100,0 & 0,0 & 0,0 & 100,0 \\
\hline \multirow[t]{6}{*}{100} & 2 & 0,0 & 0,0 & 0,0 & 0,0 \\
\hline & 24 & 0,0 & 0,0 & 20,0 & 0,0 \\
\hline & 48 & 100,0 & 0,0 & 0,0 & 100,0 \\
\hline & 72 & 100,0 & 0,0 & 0,0 & 100,0 \\
\hline & 96 & 100,0 & 0,0 & 0,0 & 100,0 \\
\hline & 120 & 100,0 & 0,0 & 0,0 & 100,0 \\
\hline \multirow[t]{6}{*}{150} & 2 & 0,0 & 0,0 & 0,0 & 0,0 \\
\hline & 24 & 100,0 & 0,0 & 0,0 & 100,0 \\
\hline & 48 & 100,0 & 0,0 & 0,0 & 100,0 \\
\hline & 72 & 100,0 & 0,0 & 0,0 & 100,0 \\
\hline & 96 & 100,0 & 0,0 & 0,0 & 100,0 \\
\hline & 120 & 100,0 & 0,0 & 0,0 & 100,0 \\
\hline \multirow[t]{6}{*}{900} & 2 & 100,0 & 0,0 & 0,0 & 100,0 \\
\hline & 24 & 100,0 & 0,0 & 0,0 & 100,0 \\
\hline & 48 & 100,0 & 0,0 & 0,0 & 100,0 \\
\hline & 72 & 100,0 & 0,0 & 0,0 & 100,0 \\
\hline & 96 & 100,0 & 0,0 & 0,0 & 100,0 \\
\hline & 120 & 100,0 & 0,0 & 0,0 & 100,0 \\
\hline \multirow[t]{2}{*}{$\mathbf{P Z Q}^{\mathbf{b}, \mathbf{c}}$} & 2 & 100,0 & 0,0 & 0,0 & 100,0 \\
\hline & 24 & 100,0 & 0,0 & 0,0 & 100,0 \\
\hline
\end{tabular}

a Porcentagem em relação a 20 vermes.

${ }^{\mathrm{b}}$ Em DMSO 0,2\% no meio RPMI.

${ }^{c}$ Controle positivo: Praziquantel (PZQ $3 \mu \mathrm{g} / \mathrm{ml}$ ).

A atividade motora foi monitorada em estereomicroscópio e avaliada qualitativamente.

Os valores correspondem a três experimentos feitos em triplicatas ou quadruplicatas. 
Em Schistosoma mansoni, o controle da motilidade está associado a importantes neurotransmissores ou neuromoduladores, tais como serotonina, dopamina, acetilcolina, adrenalina, noradrenalina, neuropeptídeos relacionados a FMRF-amidas (FaRPs), $y$-ácido aminobutírico (GABA) e glutamato (PAX e BENNETT, 1991; SANGSTER et al., 2005; NOËL et al., 2008; MARKS e MAULE, 2010; TAMAN e RIBEIRO, 2009, 2011). Desta forma, os neurotransmissores são possíveis alvos de agentes esquistossomicidas, sobretudo depois de ter sido mostrado que agonistas e/ou antagonistas desses sistemas produziram alterações do padrão de atividade motora do verme (SANGSTER et al., 2005; NOËL et al., 2008). Sugere-se que alguns compostos esquistossomicidas como, por exemplo, oxamniquina, metrifonato, hicantona, lucantona e imidazolidinas causam alterações na motilidade dos parasitas por atuarem em receptores de acetilcolina (CIOLI; PICA-MATTOCCIA; ARCHER, 1995; DUBOIS et al., 2009; NEVES et al., 2010). Assim, levando em consideração as dados já assinalados na literatura, é possível que as alterações na atividade motora de adultos de $S$. mansoni em presença de compostos ou extratos estejam associadas à neurotransmissores ou neuromoduladores.

As observações efetuadas nas culturas de $S$. mansoni revelaram outro aspecto interessante do comportamento dos parasitas adultos. Nas concentrações letais dos compostos e extratos houve a separação dos casais de vermes antes da ação helminticida, mais notadamente com os compostos piplartina e piperina, bem como os extratos de Piper tuberculatum, Piper crassinervium, Piper diospyrifolium, Piper fuligineum e Piper gaudichaudianum (Tabelas 7, 10, 12-16). Entretanto, os compostos dermaseptina e grandisina e o extrato das folhas de Pothomorphe umbellata não induziram a separação dos parasitas, independentemente da concentração, durante todo o período de incubação (Tabelas 8, 11 e 17).

Corroborando os nossos resultados, o pareamento dos adultos de $S$. mansoni em presença de compostos ou extratos esquistossomicidas foi assinalado recentemente em alguns estudos in vitro. Por exemplo, Parreira et al. (2010) mostraram que o óleo essencial extraído de folhas de Baccharis dracunculifolia não causa a separação dos parasitas na concentração de $10 \mu \mathrm{g} / \mathrm{ml}$; no entanto, os vermes não se mantiveram acasalados quando a concentração do óleo essencial é aumentada para $50 \mu \mathrm{g} / \mathrm{ml}$. Magalhães et al. (2010) mostraram, em experimentos com floroglucinóis obtidos do rizoma de samambaias do gênero Dryopteris, que aspidina e ácido flavaspídico (ambos com $10 \mu \mathrm{M}$ e $100 \mu \mathrm{M}$ ) causam a separação dos casais, enquanto a desaspidina (10 $\mu \mathrm{M}$ a $100 \mu \mathrm{M}$ ) possui efeito letal sem interferir no pareamento dos helmintos; além disso, os mesmos autores relatam que o composto aspidinol entre $10 \mu \mathrm{M}$ e $50 \mu \mathrm{M}$ não afeta os pares de vermes, mas na concentração de $100 \mu \mathrm{M}$ separa todos os parasitas. A separação dos casais de $S$. mansoni previamente a ação helminticida também foi 
relatada com curcumina $50 \mu \mathrm{M}$ e imidazolidinas $160 \mu \mathrm{M}$ a $140 \mu \mathrm{M}$ (MAGALHÃES et al., 2010; NEVES et al., 2010).

Em Schistosoma mansoni sabe-se que entre o tegumento e as células subtegumentares encontra-se uma região de musculatura lisa, organizada em camadas circulares e longitudinais, com algumas fibras radiais, particularmente no verme macho. A musculatura longitudinal é importante para a motilidade do verme, enquanto que a musculatura circular tem como principal função a manutenção do canal ginecóforo e, portanto, o pareamento do casal de vermes (PAX e BENNETT, 1991; PAX et al., 1996; MAIR et al., 1998, 2000; NOËL et al., 2008). Assim, levando em consideração as dados já assinalados na literatura, é possível que os compostos e extratos tenham afetado a musculatura do parasitas, causando a separação dos casais de Schistosoma. 


\subsection{Efeito de compostos e extratos no tegumento de adultos de Schistosoma mansoni}


O tegumento das espécies de Schistosoma é um dos principais alvos quimioterápicos. De fato, os compostos atuais que são utilizados na terapêutica clínica como praziquantel, artemeter e mefloquina causam alterações morfológicas no tegumento dos parasitas (SHUHUA et al., 2000; XIAO et al., 2000b; WILLIAM et al., 2001; DOENHOFF et al., 2008; MANNECK et al., 2010). Além de proteção, o tegumento é especializado para absorção e secreção, e para atuar como sítio das ações imunológicas do hospedeiro (SKELLY e ALAN WILSON, 2006; VAN HELLEMOND et al., 2006; FAGHIRI et al., 2010; KEISER, 2010; XAVIER et al., 2010). O objetivo desta parte do trabalho foi verificar se os compostos e extratos vegetais causam alterações no tegumento de adultos de Schistosoma mansoni.

\subsubsection{Alterações no tegumento de adultos de Schistosoma mansoni em presença de compostos e extratos}

O efeito dos compostos e extratos no tegumento dos adultos de Schistosoma mansoni foi diariamente monitorado em microscópio invertido com técnica de campo claro ou contraste de interferência. Em geral, todos os compostos e extratos estudados causaram danos nos tegumentos dos helmintos, com exceção da lignana grandisina, de forma diretamente dependente da concentração e do tempo de incubação. As alterações morfológicas na superfície dos parasitas foram qualitativamente definidas como "leve" ou "significativa" (Tabelas 18-28).

Considerando os compostos ensaiados, observações morfológicas indicaram alterações tegumentares em vermes machos e fêmeas, respectivamente, quando em presença de piplartina $3 \mu \mathrm{g} / \mathrm{ml}$ e $20 \mu \mathrm{g} / \mathrm{ml}$ e dermaseptina $50 \mu \mathrm{g} / \mathrm{ml}$ e $75 \mu \mathrm{g} / \mathrm{ml}$; além disso, notou-se dano no tegumento de parasitas machos com epiisopiloturina $150 \mu \mathrm{g} / \mathrm{ml}$ e em ambos os sexos com piperina $600 \mu \mathrm{g} / \mathrm{ml}$ (Tabelas 18-21). Nos extratos vegetais observou-se alteração no tegumento de machos e fêmeas de $S$. mansoni, respectivamente, quando em presença de Piper tuberculatum $3 \mu \mathrm{g} / \mathrm{ml}$ e $10 \mu \mathrm{g} / \mathrm{ml}, P$. crassinervium $60 \mu \mathrm{g} / \mathrm{ml}$ e $70 \mu \mathrm{g} / \mathrm{ml}, P$. diospyrifolium $250 \mu \mathrm{g} / \mathrm{ml}$ e $70 \mu \mathrm{g} / \mathrm{ml}, \quad P$. fuligineum $70 \mu \mathrm{g} / \mathrm{ml}$ e $50 \mu \mathrm{g} / \mathrm{ml}$, P. gaudichaudianum $75 \mu \mathrm{g} / \mathrm{ml}$ e $150 \mu \mathrm{g} / \mathrm{ml}$ e Pothomorphe umbellata $40 \mu \mathrm{g} / \mathrm{ml}$ e $75 \mu \mathrm{g} / \mathrm{ml}$ (Tabelas 23-28). 
Tabela 18 - Alterações tegumentares em adultos de Schistosoma mansoni durante incubação com a amida piplartina

\begin{tabular}{|c|c|c|c|c|c|c|}
\hline \multirow{3}{*}{$\begin{array}{l}\text { Piplartina } \\
(\mu \mathrm{g} / \mathrm{ml})^{\mathrm{b}}\end{array}$} & \multirow{3}{*}{$\begin{array}{l}\text { Tempo de } \\
\text { incubação } \\
\text { (h) }\end{array}$} & \multirow{3}{*}{$\begin{array}{c}\text { Mortalidade } \\
(\%)^{a}\end{array}$} & \multicolumn{4}{|c|}{ Alterações tegumentares $(\%)^{a}$} \\
\hline & & & \multicolumn{2}{|c|}{ Leve } & \multicolumn{2}{|c|}{ Significativa } \\
\hline & & & Macho & Fêmea & Macho & Fêmea \\
\hline \multirow[t]{3}{*}{0} & 24 & 0,0 & 0,0 & 0,0 & 0,0 & 0,0 \\
\hline & 48 & 0,0 & 0,0 & 0,0 & 0,0 & 0,0 \\
\hline & 72 & 0,0 & 0,0 & 0,0 & 0,0 & 0,0 \\
\hline \multirow[t]{3}{*}{3} & 24 & 0,0 & 0,0 & 0,0 & 0,0 & 0,0 \\
\hline & 48 & 0,0 & 60,0 & 0,0 & 0,0 & 0,0 \\
\hline & 72 & 100,0 & 100,0 & 0,0 & 0,0 & 0,0 \\
\hline \multirow[t]{3}{*}{4} & 24 & 50,0 & 100,0 & 0,0 & 0,0 & 0,0 \\
\hline & 48 & 100,0 & 100,0 & 0,0 & 0,0 & 0,0 \\
\hline & 72 & 100,0 & 100,0 & 0,0 & 0,0 & 0,0 \\
\hline \multirow[t]{3}{*}{5} & 24 & 100,0 & 100,0 & 0,0 & 0,0 & 0,0 \\
\hline & 48 & 100,0 & 100,0 & 0,0 & 0,0 & 0,0 \\
\hline & 72 & 100,0 & 100,0 & 0,0 & 0,0 & 0,0 \\
\hline \multirow[t]{3}{*}{10} & 24 & 100,0 & 100,0 & 0,0 & 0,0 & 0,0 \\
\hline & 48 & 100,0 & 100,0 & 0,0 & 0,0 & 0,0 \\
\hline & 72 & 100,0 & 100,0 & 0,0 & 0,0 & 0,0 \\
\hline \multirow[t]{3}{*}{20} & 24 & 100,0 & 100,0 & 100,0 & 0,0 & 0,0 \\
\hline & 48 & 100,0 & 100,0 & 100,0 & 0,0 & 0,0 \\
\hline & 72 & 100,0 & 100,0 & 100,0 & 0,0 & 0,0 \\
\hline \multirow[t]{3}{*}{30} & 24 & 100,0 & 0,0 & 50,0 & 100,0 & 50,0 \\
\hline & 48 & 100,0 & 0,0 & 50,0 & 100,0 & 50,0 \\
\hline & 72 & 100,0 & 0,0 & 50,0 & 100,0 & 50,0 \\
\hline \multirow[t]{3}{*}{40} & 24 & 100,0 & 0,0 & 0,0 & 100,0 & 100,0 \\
\hline & 48 & 100,0 & 0,0 & 0,0 & 100,0 & 100,0 \\
\hline & 72 & 100,0 & 0,0 & 0,0 & 100,0 & 100,0 \\
\hline $\mathbf{P Z Q}^{\mathrm{b}, \mathrm{c}}$ & 24 & 100,0 & 30,0 & 10,0 & 70,0 & 90,0 \\
\hline
\end{tabular}

a Porcentagem em relação a 10 pares de vermes.

${ }^{b}$ Em DMSO 0,2\% no meio RPMI.

c Controle positivo: Praziquantel (PZQ $3 \mu \mathrm{g} / \mathrm{ml}$ ).

As alterações tegumentares foram avaliadas qualitativamente usando microscópio invertido com técnica de campo claro ou contraste de interferência.

Os valores correspondem a três experimentos feitos em triplicatas ou quadruplicatas. 
Tabela 19 - Alterações tegumentares em adultos de Schistosoma mansoni durante incubação com o peptídeo dermaseptina 01

\begin{tabular}{|c|c|c|c|c|c|c|}
\hline \multirow{3}{*}{$\begin{array}{l}\text { Dermaseptina } \\
\qquad(\mu \mathrm{g} / \mathrm{ml})\end{array}$} & \multirow{3}{*}{$\begin{array}{l}\text { Tempo de } \\
\text { incubação } \\
\text { (h) }\end{array}$} & \multirow{3}{*}{$\begin{array}{c}\text { Mortalidade } \\
(\%)^{\mathrm{a}}\end{array}$} & \multicolumn{4}{|c|}{ Alterações tegumentares $(\%)^{a}$} \\
\hline & & & \multicolumn{2}{|c|}{ Leve } & \multicolumn{2}{|c|}{ Significativa } \\
\hline & & & Macho & Fêmea & Macho & Fêmea \\
\hline \multirow[t]{5}{*}{$\mathbf{0}$} & 24 & 0,0 & 0,0 & 0,0 & 0,0 & 0,0 \\
\hline & 48 & 0,0 & 0,0 & 0,0 & 0,0 & 0,0 \\
\hline & 72 & 0,0 & 0,0 & 0,0 & 0,0 & 0,0 \\
\hline & 96 & 0,0 & 0,0 & 0,0 & 0,0 & 0,0 \\
\hline & 120 & 0,0 & 0,0 & 0,0 & 0,0 & 0,0 \\
\hline \multirow[t]{5}{*}{50} & 24 & 0,0 & 0,0 & 0,0 & 0,0 & 0,0 \\
\hline & 48 & 0,0 & 0,0 & 0,0 & 0,0 & 0,0 \\
\hline & 72 & 50,0 & 0,0 & 0,0 & 0,0 & 0,0 \\
\hline & 96 & 60,0 & 0,0 & 0,0 & 0,0 & 0,0 \\
\hline & 120 & 100,0 & 40,0 & 0,0 & 0,0 & 0,0 \\
\hline \multirow[t]{5}{*}{75} & 24 & 0,0 & 0,0 & 0,0 & 0,0 & 0,0 \\
\hline & 48 & 0,0 & 0,0 & 0,0 & 0,0 & 0,0 \\
\hline & 72 & 50,0 & 100,0 & 100,0 & 0,0 & 0,0 \\
\hline & 96 & 100,0 & 0,0 & 0,0 & 100,0 & 100,0 \\
\hline & 120 & 100,0 & 0,0 & 0,0 & 100,0 & 100,0 \\
\hline \multirow[t]{5}{*}{100} & 24 & 0,0 & 100,0 & 100,0 & 0,0 & 0,0 \\
\hline & 48 & 100,0 & 0,0 & 0,0 & 100,0 & 100,0 \\
\hline & 72 & 100,0 & 0,0 & 0,0 & 100,0 & 100,0 \\
\hline & 96 & 100,0 & 0,0 & 0,0 & 100,0 & 100,0 \\
\hline & 120 & 100,0 & 0,0 & 0,0 & 100,0 & 100,0 \\
\hline \multirow[t]{5}{*}{150} & 24 & 40,0 & 0,0 & 0,0 & 100,0 & 100,0 \\
\hline & 48 & 100,0 & 0,0 & 0,0 & 100,0 & 100,0 \\
\hline & 72 & 100,0 & 0,0 & 0,0 & 100,0 & 100,0 \\
\hline & 96 & 100,0 & 0,0 & 0,0 & 100,0 & 100,0 \\
\hline & 120 & 100,0 & 0,0 & 0,0 & 100,0 & 100,0 \\
\hline $\mathbf{P Z Q}^{\mathbf{b}}$ & 24 & 100,0 & 30,0 & 10,0 & 70,0 & 90,0 \\
\hline
\end{tabular}

a Porcentagem em relação a 10 pares de vermes.

${ }^{\mathrm{b}}$ Controle positivo: Praziquantel (PZQ $3 \mu \mathrm{g} / \mathrm{ml}$ ).

As alterações tegumentares foram avaliadas qualitativamente usando microscópio invertido com técnica de campo claro ou contraste de interferência.

Os valores correspondem a três experimentos feitos em triplicatas ou quadruplicatas. 
Tabela 20 - Alterações tegumentares em adultos de Schistosoma mansoni durante incubação com o alcaloide epiisopiloturina

\begin{tabular}{|c|c|c|c|c|c|c|}
\hline \multirow{3}{*}{$\begin{array}{l}\text { Epiisopiloturina } \\
(\mu \mathrm{g} / \mathrm{ml})^{\mathrm{b}}\end{array}$} & \multirow{3}{*}{$\begin{array}{l}\text { Tempo de } \\
\text { incubação } \\
\text { (h) }\end{array}$} & \multirow{3}{*}{$\begin{array}{l}\text { Mortalidade } \\
(\%)^{a}\end{array}$} & \multicolumn{4}{|c|}{ Alterações tegumentares $(\%)^{a}$} \\
\hline & & & \multicolumn{2}{|c|}{ Leve } & \multicolumn{2}{|c|}{ Significativa } \\
\hline & & & Macho & Fêmea & Macho & Fêmea \\
\hline \multirow[t]{5}{*}{$\mathbf{0}$} & 24 & 0,0 & 0,0 & 0,0 & 0,0 & 0,0 \\
\hline & 48 & 0,0 & 0,0 & 0,0 & 0,0 & 0,0 \\
\hline & 72 & 0,0 & 0,0 & 0,0 & 0,0 & 0,0 \\
\hline & 96 & 0,0 & 0,0 & 0,0 & 0,0 & 0,0 \\
\hline & 120 & 0,0 & 0,0 & 0,0 & 0,0 & 0,0 \\
\hline \multirow[t]{5}{*}{100} & 24 & 0,0 & 0,0 & 0,0 & 0,0 & 0,0 \\
\hline & 48 & 0,0 & 0,0 & 0,0 & 0,0 & 0,0 \\
\hline & 72 & 0,0 & 0,0 & 0,0 & 0,0 & 0,0 \\
\hline & 96 & 0,0 & 0,0 & 0,0 & 0,0 & 0,0 \\
\hline & 120 & 0,0 & 0,0 & 0,0 & 0,0 & 0,0 \\
\hline \multirow[t]{5}{*}{150} & 24 & 0,0 & 0,0 & 0,0 & 0,0 & 0,0 \\
\hline & 48 & 0,0 & 0,0 & 0,0 & 0,0 & 0,0 \\
\hline & 72 & 0,0 & 33,3 & 0,0 & 0,0 & 0,0 \\
\hline & 96 & 0,0 & 55,5 & 0,0 & 22,2 & 0,0 \\
\hline & 120 & 100,0 & 0,0 & 0,0 & 100 & 0,0 \\
\hline \multirow[t]{5}{*}{200} & 24 & 0,0 & 33,3 & 0,0 & 0,0 & 0,0 \\
\hline & 48 & 0,0 & 55,5 & 0,0 & 0,0 & 0,0 \\
\hline & 72 & 100,0 & 0,0 & 0,0 & 100,0 & 0,0 \\
\hline & 96 & 100,0 & 0,0 & 0,0 & 100,0 & 0,0 \\
\hline & 120 & 100,0 & 0,0 & 0,0 & 100,0 & 0,0 \\
\hline $\mathbf{P Z Q}^{\mathbf{b}, \mathbf{c}}$ & 24 & 100,0 & 30,0 & 10,0 & 70,0 & 90,0 \\
\hline
\end{tabular}

a Porcentagem em relação a 9 pares de vermes.

b Em DMSO 0,2\% no meio RPMI.

c Controle positivo: Praziquantel (PZQ $3 \mu \mathrm{g} / \mathrm{ml}$ ).

As alterações tegumentares foram avaliadas qualitativamente usando microscópio invertido com técnica de campo claro ou contraste de interferência.

Os valores correspondem a três experimentos feitos em triplicatas. 
Tabela 21. Alterações tegumentares em adultos de Schistosoma mansoni durante incubação com a amida piperina

\begin{tabular}{|c|c|c|c|c|c|c|}
\hline \multirow{3}{*}{$\begin{array}{l}\text { Piperina } \\
(\mu \mathrm{g} / \mathrm{ml})^{\mathrm{b}}\end{array}$} & \multirow{3}{*}{$\begin{array}{l}\text { Tempo de } \\
\text { incubação } \\
\text { (h) }\end{array}$} & \multirow{3}{*}{$\begin{array}{c}\text { Mortalidade } \\
(\%)^{\mathrm{a}}\end{array}$} & \multicolumn{4}{|c|}{ Alterações tegumentares $(\%)^{a}$} \\
\hline & & & \multicolumn{2}{|c|}{ Leve } & \multicolumn{2}{|c|}{ Significativa } \\
\hline & & & Macho & Fêmea & Macho & Fêmea \\
\hline \multirow[t]{3}{*}{$\mathbf{0}$} & 24 & 0,0 & 0,0 & 0,0 & 0,0 & 0,0 \\
\hline & 48 & 0,0 & 0,0 & 0,0 & 0,0 & 0,0 \\
\hline & 72 & 0,0 & 0,0 & 0,0 & 0,0 & 0,0 \\
\hline \multirow[t]{3}{*}{600} & 24 & 0,0 & 100,0 & 100,0 & 0,0 & 0,0 \\
\hline & 48 & 0,0 & 100,0 & 100,0 & 0,0 & 0,0 \\
\hline & 72 & 100,0 & 0,0 & 0,0 & 100,0 & 100,0 \\
\hline \multirow[t]{3}{*}{650} & 24 & 0,0 & 100,0 & 75,0 & 0,0 & 25,0 \\
\hline & 48 & 0,0 & 100,0 & 8,3 & 0,0 & 91,6 \\
\hline & 72 & 100,0 & 0,0 & 0,0 & 100,0 & 100,0 \\
\hline \multirow[t]{3}{*}{700} & 24 & 0,0 & 100,0 & 60,0 & 0,0 & 40,0 \\
\hline & 48 & 66,6 & 13,3 & 0,0 & 86,6 & 100,0 \\
\hline & 72 & 100,0 & 0,0 & 0,0 & 100,0 & 100,0 \\
\hline \multirow[t]{3}{*}{750} & 24 & 0,0 & 100,0 & 58,3 & 0,0 & 41,6 \\
\hline & 48 & 100,0 & 0,0 & 0,0 & 100,0 & 100,0 \\
\hline & 72 & 100,0 & 0,0 & 0,0 & 100,0 & 100,0 \\
\hline \multirow[t]{3}{*}{800} & 24 & 0,0 & 40,0 & 40,0 & 60,0 & 60,0 \\
\hline & 48 & 100,0 & 0,0 & 0,0 & 100,0 & 100,0 \\
\hline & 72 & 100,0 & 0,0 & 0,0 & 100,0 & 100,0 \\
\hline \multirow[t]{3}{*}{850} & 24 & 41,6 & 25,0 & 16,6 & 75,0 & 83,3 \\
\hline & 48 & 100,0 & 6,6 & 0,0 & 93,3 & 100,0 \\
\hline & 72 & 100,0 & 6,6 & 0,0 & 93,3 & 100,0 \\
\hline \multirow[t]{3}{*}{900} & 24 & 60,0 & 0,0 & 0,0 & 100,0 & 100,0 \\
\hline & 48 & 100,0 & 0,0 & 0,0 & 100,0 & 100,0 \\
\hline & 72 & 100,0 & 0,0 & 0,0 & 100,0 & 100,0 \\
\hline \multirow[t]{3}{*}{950} & 24 & 100,0 & 0,0 & 0,0 & 100,0 & 100,0 \\
\hline & 48 & 100,0 & 0,0 & 0,0 & 100,0 & 100,0 \\
\hline & 72 & 100,0 & 0,0 & 0,0 & 100,0 & 100,0 \\
\hline $\mathbf{P Z Q}^{\mathrm{b}, \mathrm{c}}$ & 24 & 100,0 & 30,0 & 10,0 & 70,0 & 90,0 \\
\hline
\end{tabular}

a Porcentagem em relação a 12 ou 15 pares de vermes.

b Em DMSO 0,2\% no meio RPMI.

c Controle positivo: Praziquantel (PZQ $3 \mu \mathrm{g} / \mathrm{ml}$ ).

As alterações tegumentares foram avaliadas qualitativamente usando microscópio invertido com técnica de campo claro ou contraste de interferência.

Os valores correspondem a, pelo menos, três experimentos feitos em triplicatas ou quadruplicatas. 
Tabela 22 - Alterações tegumentares em adultos de Schistosoma mansoni durante incubação com a lignana grandisina

\begin{tabular}{|c|c|c|c|c|c|c|}
\hline \multirow{3}{*}{$\begin{array}{c}\text { Grandisina } \\
(\mu \mathrm{g} / \mathrm{ml})^{\mathrm{b}}\end{array}$} & \multirow{3}{*}{$\begin{array}{l}\text { Tempo de } \\
\text { incubação } \\
\text { (h) }\end{array}$} & \multirow{3}{*}{$\begin{array}{c}\text { Mortalidade } \\
(\%)^{\mathrm{a}}\end{array}$} & \multicolumn{4}{|c|}{ Alterações tegumentares $(\%)^{a}$} \\
\hline & & & \multicolumn{2}{|c|}{ Leve } & \multicolumn{2}{|c|}{ Significativa } \\
\hline & & & Macho & Fêmea & Macho & Fêmea \\
\hline \multirow[t]{5}{*}{$\mathbf{0}$} & 24 & 0,0 & 0,0 & 0,0 & 0,0 & 0,0 \\
\hline & 48 & 0,0 & 0,0 & 0,0 & 0,0 & 0,0 \\
\hline & 72 & 0,0 & 0,0 & 0,0 & 0,0 & 0,0 \\
\hline & 96 & 0,0 & 0,0 & 0,0 & 0,0 & 0,0 \\
\hline & 120 & 0,0 & 0,0 & 0,0 & 0,0 & 0,0 \\
\hline \multirow[t]{5}{*}{1000} & 24 & 0,0 & 0,0 & 0,0 & 0,0 & 0,0 \\
\hline & 48 & 0,0 & 0,0 & 0,0 & 0,0 & 0,0 \\
\hline & 72 & 0,0 & 0,0 & 0,0 & 0,0 & 0,0 \\
\hline & 96 & 100,0 & 0,0 & 0,0 & 0,0 & 0,0 \\
\hline & 120 & 100,0 & 0,0 & 0,0 & 0,0 & 0,0 \\
\hline \multirow[t]{5}{*}{1500} & 24 & 0,0 & 0,0 & 0,0 & 0,0 & 0,0 \\
\hline & 48 & 0,0 & 0,0 & 0,0 & 0,0 & 0,0 \\
\hline & 72 & 100,0 & 0,0 & 0,0 & 0,0 & 0,0 \\
\hline & 96 & 100,0 & 0,0 & 0,0 & 0,0 & 0,0 \\
\hline & 120 & 100,0 & 0,0 & 0,0 & 0,0 & 0,0 \\
\hline \multirow[t]{5}{*}{2000} & 24 & 100,0 & 0,0 & 0,0 & 0,0 & 0,0 \\
\hline & 48 & 100,0 & 0,0 & 0,0 & 0,0 & 0,0 \\
\hline & 72 & 100,0 & 0,0 & 0,0 & 0,0 & 0,0 \\
\hline & 96 & 100,0 & 0,0 & 0,0 & 0,0 & 0,0 \\
\hline & 120 & 100,0 & 0,0 & 0,0 & 0,0 & 0,0 \\
\hline $\mathbf{P Z Q}^{\mathbf{b}, \mathbf{c}}$ & 24 & 100,0 & 30,0 & 10,0 & 70,0 & 90,0 \\
\hline
\end{tabular}

a Porcentagem em relação a 10 pares de vermes.

b Em DMSO 0,2\% no meio RPMI.

c Controle positivo: Praziquantel (PZQ $3 \mu \mathrm{g} / \mathrm{ml}$ ).

As alterações tegumentares foram avaliadas qualitativamente usando microscópio invertido com técnica de campo claro ou contraste de interferência.

Os valores correspondem a três experimentos feitos em triplicatas ou quadruplicatas. 
Tabela 23 - Alterações tegumentares em adultos de Schistosoma mansoni durante incubação com o extrato de Piper tuberculatum

\begin{tabular}{|c|c|c|c|c|c|c|}
\hline \multirow{3}{*}{$\begin{array}{l}\text { Extrato } \\
(\mu \mathrm{g} / \mathrm{ml})^{b}\end{array}$} & \multirow{3}{*}{$\begin{array}{l}\text { Tempo de } \\
\text { incubação } \\
\text { (h) }\end{array}$} & \multirow{3}{*}{$\begin{array}{c}\text { Mortalidade } \\
(\%)^{a}\end{array}$} & \multicolumn{4}{|c|}{ Alterações tegumentares $(\%)^{a}$} \\
\hline & & & \multicolumn{2}{|c|}{ Leve } & \multicolumn{2}{|c|}{ Significativa } \\
\hline & & & Macho & Fêmea & Macho & Fêmea \\
\hline \multirow[t]{3}{*}{0} & 24 & 0,0 & 0,0 & 0,0 & 0,0 & 0,0 \\
\hline & 48 & 0,0 & 0,0 & 0,0 & 0,0 & 0,0 \\
\hline & 72 & 0,0 & 0,0 & 0,0 & 0,0 & 0,0 \\
\hline \multirow[t]{3}{*}{3} & 24 & 0,0 & 0,0 & 0,0 & 0,0 & 0,0 \\
\hline & 48 & 0,0 & 0,0 & 0,0 & 0,0 & 0,0 \\
\hline & 72 & 0,0 & 10,0 & 0,0 & 0,0 & 0,0 \\
\hline \multirow[t]{3}{*}{5} & 24 & 0,0 & 0,0 & 0,0 & 0,0 & 0,0 \\
\hline & 48 & 0,0 & 0,0 & 0,0 & 0,0 & 0,0 \\
\hline & 72 & 100,0 & 80,0 & 0,0 & 0,0 & 0,0 \\
\hline \multirow[t]{3}{*}{10} & 24 & 100,0 & 60,0 & 10,0 & 40,0 & 0,0 \\
\hline & 48 & 100,0 & 60,0 & 10,0 & 40,0 & 0,0 \\
\hline & 72 & 100,0 & 60,0 & 10,0 & 40,0 & 0,0 \\
\hline \multirow[t]{3}{*}{15} & 24 & 100,0 & 40,0 & 40,0 & 60,0 & 0,0 \\
\hline & 48 & 100,0 & 40,0 & 40,0 & 60,0 & 0,0 \\
\hline & 72 & 100,0 & 40,0 & 40,0 & 60,0 & 0,0 \\
\hline \multirow[t]{3}{*}{25} & 24 & 100,0 & 10,0 & 60,0 & 80,0 & 0,0 \\
\hline & 48 & 100,0 & 10,0 & 60,0 & 80,0 & 0,0 \\
\hline & 72 & 100,0 & 10,0 & 60,0 & 80,0 & 0,0 \\
\hline \multirow[t]{3}{*}{50} & 24 & 100,0 & 10,0 & 100,0 & 90,0 & 0,0 \\
\hline & 48 & 100,0 & 10,0 & 100,0 & 90,0 & 0,0 \\
\hline & 72 & 100,0 & 10,0 & 100,0 & 90,0 & 0,0 \\
\hline \multirow[t]{3}{*}{75} & 24 & 100,0 & 0,0 & 40,0 & 100,0 & 60,0 \\
\hline & 48 & 100,0 & 0,0 & 40,0 & 100,0 & 60,0 \\
\hline & 72 & 100,0 & 0,0 & 40,0 & 100,0 & 60,0 \\
\hline \multirow[t]{3}{*}{100} & 24 & 100,0 & 0,0 & 0,0 & 100,0 & 100,0 \\
\hline & 48 & 100,0 & 0,0 & 0,0 & 100,0 & 100,0 \\
\hline & 72 & 100,0 & 0,0 & 0,0 & 100,0 & 100,0 \\
\hline $\mathbf{P Z Q} \mathbf{Q}^{\mathbf{b}, \mathrm{c}}$ & 24 & 100,0 & 30,0 & 10,0 & 70,0 & 90,0 \\
\hline
\end{tabular}

a Porcentagem em relação a 10 pares de vermes.

${ }^{\mathrm{b}}$ Em DMSO 0,2\% no meio RPMI.

c Controle positivo: Praziquantel (PZQ $3 \mu \mathrm{g} / \mathrm{ml}$ ).

As alterações tegumentares foram avaliadas qualitativamente usando microscópio invertido com técnica de campo claro ou contraste de interferência.

Os valores correspondem a três experimentos feitos em triplicatas ou quadruplicatas. 
Tabela 24 - Alterações tegumentares em adultos de Schistosoma mansoni durante incubação com o extrato de Piper crassinervium

\begin{tabular}{|c|c|c|c|c|c|c|}
\hline \multirow{3}{*}{$\begin{array}{l}\text { Extrato } \\
(\mu \mathrm{g} / \mathrm{ml})^{b}\end{array}$} & \multirow{3}{*}{$\begin{array}{l}\text { Tempo de } \\
\text { incubação } \\
\text { (h) }\end{array}$} & \multirow{3}{*}{$\begin{array}{c}\text { Mortalidade } \\
(\%)^{\mathrm{a}}\end{array}$} & \multicolumn{4}{|c|}{ Alterações tegumentares $(\%)^{a}$} \\
\hline & & & \multicolumn{2}{|c|}{ Leve } & \multicolumn{2}{|c|}{ Significativa } \\
\hline & & & Macho & Fêmea & Macho & Fêmea \\
\hline \multirow[t]{3}{*}{0} & 24 & 0,0 & 0,0 & 0,0 & 0,0 & 0,0 \\
\hline & 48 & 0,0 & 0,0 & 0,0 & 0,0 & 0,0 \\
\hline & 72 & 0,0 & 0,0 & 0,0 & 0,0 & 0,0 \\
\hline \multirow[t]{3}{*}{60} & 24 & 0,0 & 20,0 & 0,0 & 0,0 & 0,0 \\
\hline & 48 & 0,0 & 50,0 & 0,0 & 0,0 & 0,0 \\
\hline & 72 & 100,0 & 70,0 & 0,0 & 30,0 & 0,0 \\
\hline \multirow[t]{3}{*}{70} & 24 & 50,0 & 60,0 & 50,0 & 40,0 & 50,0 \\
\hline & 48 & 100,0 & 60,0 & 50,0 & 40,0 & 50,0 \\
\hline & 72 & 100,0 & 60,0 & 50,0 & 40,0 & 50,0 \\
\hline \multirow[t]{3}{*}{100} & 24 & 100,0 & 0,0 & 10,0 & 100,0 & 90,0 \\
\hline & 48 & 100,0 & 0,0 & 10,0 & 100,0 & 90,0 \\
\hline & 72 & 100,0 & 0,0 & 10,0 & 100,0 & 90,0 \\
\hline \multirow[t]{3}{*}{150} & 24 & 100,0 & 0,0 & 0,0 & 100,0 & 100,0 \\
\hline & 48 & 100,0 & 0,0 & 0,0 & 100,0 & 100,0 \\
\hline & 72 & 100,0 & 0,0 & 0,0 & 100,0 & 100,0 \\
\hline $\mathbf{P Z Q}^{\mathbf{b}, \mathbf{c}}$ & 24 & 100,0 & 30,0 & 10,0 & 70,0 & 90,0 \\
\hline
\end{tabular}

a Porcentagem em relação a 10 pares de vermes.

${ }^{\mathrm{b}}$ Em DMSO 0,2\% no meio RPMI.

c Controle positivo: Praziquantel (PZQ $3 \mu \mathrm{g} / \mathrm{ml}$ ).

As alterações tegumentares foram avaliadas qualitativamente usando microscópio invertido com técnica de campo claro ou contraste de interferência.

Os valores correspondem a três experimentos feitos em triplicatas ou quadruplicatas. 
Tabela 25 - Alterações tegumentares em adultos de Schistosoma mansoni durante incubação com o extrato de Piper diospyrifolium

\begin{tabular}{|c|c|c|c|c|c|c|}
\hline \multirow{3}{*}{$\begin{array}{l}\text { Extrato } \\
(\mu \mathrm{g} / \mathrm{ml})^{b}\end{array}$} & \multirow{3}{*}{$\begin{array}{l}\text { Tempo de } \\
\text { incubação } \\
\text { (h) }\end{array}$} & \multirow{3}{*}{$\begin{array}{c}\text { Mortalidade } \\
(\%)^{\mathrm{a}}\end{array}$} & \multicolumn{4}{|c|}{ Alterações tegumentares $(\%)^{a}$} \\
\hline & & & \multicolumn{2}{|c|}{ Leve } & \multicolumn{2}{|c|}{ Significativa } \\
\hline & & & Macho & Fêmea & Macho & Fêmea \\
\hline \multirow[t]{3}{*}{0} & 24 & 0,0 & 0,0 & 0,0 & 0,0 & 0,0 \\
\hline & 48 & 0,0 & 0,0 & 0,0 & 0,0 & 0,0 \\
\hline & 72 & 0,0 & 0,0 & 0,0 & 0,0 & 0,0 \\
\hline \multirow[t]{3}{*}{70} & 24 & 0,0 & 0,0 & 0,0 & 0,0 & 0,0 \\
\hline & 48 & 0,0 & 0,0 & 100,0 & 0,0 & 0,0 \\
\hline & 72 & 63,3 & 0,0 & 100,0 & 0,0 & 0,0 \\
\hline \multirow[t]{3}{*}{100} & 24 & 0,0 & 0,0 & 100,0 & 0,0 & 0,0 \\
\hline & 48 & 63,3 & 0,0 & 0,0 & 0,0 & 100,0 \\
\hline & 72 & 100,0 & 0,0 & 0,0 & 0,0 & 100,0 \\
\hline \multirow[t]{3}{*}{250} & 24 & 100,0 & 100,0 & 0,0 & 0,0 & 100,0 \\
\hline & 48 & 100,0 & 100,0 & 0,0 & 0,0 & 100,0 \\
\hline & 72 & 100,0 & 100,0 & 0,0 & 0,0 & 100,0 \\
\hline \multirow[t]{3}{*}{800} & 24 & 100,0 & 100,0 & 0,0 & 0,0 & 100,0 \\
\hline & 48 & 100,0 & 100,0 & 0,0 & 0,0 & 100,0 \\
\hline & 72 & 100,0 & 100,0 & 0,0 & 0,0 & 100,0 \\
\hline $\mathbf{P Z Q}^{\mathbf{b}, \mathbf{c}}$ & 24 & 100,0 & 30,0 & 10,0 & 70,0 & 90,0 \\
\hline
\end{tabular}

a Porcentagem em relação a 12 ou 15 pares de vermes.

b Em DMSO 0,2\% no meio RPMI.

c Controle positivo: Praziquantel (PZQ $3 \mu \mathrm{g} / \mathrm{ml}$ ).

As alterações tegumentares foram avaliadas qualitativamente usando microscópio invertido com técnica de campo claro ou contraste de interferência.

Os valores correspondem a, pelo menos, três experimentos feitos em triplicatas ou quadruplicatas. 
Tabela 26 - Alterações tegumentares em adultos de Schistosoma mansoni durante incubação com o extrato de Piper fuligineum

\begin{tabular}{|c|c|c|c|c|c|c|}
\hline \multirow{3}{*}{$\begin{array}{l}\text { Extrato } \\
(\mu \mathrm{g} / \mathrm{ml})^{b}\end{array}$} & \multirow{3}{*}{$\begin{array}{l}\text { Tempo de } \\
\text { incubação } \\
\text { (h) }\end{array}$} & \multirow{3}{*}{$\begin{array}{c}\text { Mortalidade } \\
(\%)^{a}\end{array}$} & \multicolumn{4}{|c|}{ Alterações tegumentares $(\%)^{a}$} \\
\hline & & & \multicolumn{2}{|c|}{ Leve } & \multicolumn{2}{|c|}{ Significativa } \\
\hline & & & Macho & Fêmea & Macho & Fêmea \\
\hline \multirow[t]{3}{*}{0} & 24 & 0,0 & 0,0 & 0,0 & 0,0 & 0,0 \\
\hline & 48 & 0,0 & 0,0 & 0,0 & 0,0 & 0,0 \\
\hline & 72 & 0,0 & 0,0 & 0,0 & 0,0 & 0,0 \\
\hline \multirow[t]{3}{*}{40} & 24 & 0,0 & 0,0 & 0,0 & 0,0 & 0,0 \\
\hline & 48 & 0,0 & 0,0 & 0,0 & 0,0 & 0,0 \\
\hline & 72 & 0,0 & 0,0 & 20,0 & 0,0 & 0,0 \\
\hline \multirow[t]{3}{*}{50} & 24 & 0,0 & 0,0 & 53,3 & 0,0 & 0,0 \\
\hline & 48 & 20,0 & 0,0 & 60,0 & 0,0 & 40,0 \\
\hline & 72 & 56,6 & 0,0 & 20,0 & 0,0 & 60,0 \\
\hline \multirow[t]{3}{*}{70} & 24 & 0,0 & 20,0 & 100,0 & 0,0 & 0,0 \\
\hline & 48 & 50,0 & 40,0 & 0,0 & 0,0 & 100,0 \\
\hline & 72 & 100,0 & 60,0 & 0,0 & 20,0 & 100,0 \\
\hline \multirow[t]{3}{*}{80} & 24 & 0,0 & 0,0 & 100,0 & 0,0 & 0,0 \\
\hline & 48 & 53,3 & 40,0 & 0,0 & 20,0 & 100,0 \\
\hline & 72 & 100,0 & 33,3 & 0,0 & 66,6 & 100,0 \\
\hline \multirow[t]{3}{*}{90} & 24 & 0,0 & 13,3 & 20,0 & 0,0 & 60,0 \\
\hline & 48 & 100,0 & 20,0 & 0,0 & 80,0 & 100,0 \\
\hline & 72 & 100,0 & 20,0 & 0,0 & 80,0 & 100,0 \\
\hline \multirow[t]{3}{*}{100} & 24 & 50,0 & 100,0 & 0,0 & 0,0 & 100,0 \\
\hline & 48 & 100,0 & 0,0 & 0,0 & 100,0 & 100,0 \\
\hline & 72 & 100,0 & 0,0 & 0,0 & 100,0 & 100,0 \\
\hline \multirow[t]{3}{*}{150} & 24 & 100,0 & 0,0 & 0,0 & 100,0 & 100,0 \\
\hline & 48 & 100,0 & 0,0 & 0,0 & 100,0 & 100,0 \\
\hline & 72 & 100,0 & 0,0 & 0,0 & 100,0 & 100,0 \\
\hline $\mathbf{P Z Q} \mathbf{Q}^{\mathbf{b}, \mathrm{c}}$ & 24 & 100,0 & 30,0 & 10,0 & 70,0 & 90,0 \\
\hline
\end{tabular}

a Porcentagem em relação a 12 ou 15 pares de vermes.

${ }^{b}$ Em DMSO 0,2\% no meio RPMI.

c Controle positivo: Praziquantel (PZQ $3 \mu \mathrm{g} / \mathrm{ml}$ ).

As alterações tegumentares foram avaliadas qualitativamente usando microscópio invertido com técnica de campo claro ou contraste de interferência.

Os valores correspondem a, pelo menos, três experimentos feitos em triplicatas ou quadruplicatas. 
Tabela 27 - Alterações tegumentares em adultos de Schistosoma mansoni durante incubação com o extrato de Piper gaudichaudianum

\begin{tabular}{|c|c|c|c|c|c|c|}
\hline \multirow{3}{*}{$\begin{array}{l}\text { Extrato } \\
(\mu \mathrm{g} / \mathrm{ml})^{b}\end{array}$} & \multirow{3}{*}{$\begin{array}{l}\text { Tempo de } \\
\text { incubação } \\
\text { (h) }\end{array}$} & \multirow{3}{*}{$\begin{array}{c}\text { Mortalidade } \\
(\%)^{a}\end{array}$} & \multicolumn{4}{|c|}{ Alterações tegumentares $(\%)^{a}$} \\
\hline & & & \multicolumn{2}{|c|}{ Leve } & \multicolumn{2}{|c|}{ Significativa } \\
\hline & & & Macho & Fêmea & Macho & Fêmea \\
\hline \multirow[t]{3}{*}{0} & 24 & 0,0 & 0,0 & 0,0 & 0,0 & 0,0 \\
\hline & 48 & 0,0 & 0,0 & 0,0 & 0,0 & 0,0 \\
\hline & 72 & 0,0 & 0,0 & 0,0 & 0,0 & 0,0 \\
\hline \multirow[t]{3}{*}{75} & 24 & 0,0 & 0,0 & 0,0 & 0,0 & 0,0 \\
\hline & 48 & 0,0 & 0,0 & 0,0 & 0,0 & 0,0 \\
\hline & 72 & 20,0 & 70,0 & 0,0 & 30,0 & 0,0 \\
\hline \multirow[t]{3}{*}{100} & 24 & 0,0 & 0,0 & 0,0 & 0,0 & 0,0 \\
\hline & 48 & 5,0 & 50,0 & 0,0 & 50,0 & 0,0 \\
\hline & 72 & 70,0 & 20,0 & 0,0 & 80,0 & 0,0 \\
\hline \multirow[t]{3}{*}{125} & 24 & 0,0 & 0,0 & 0,0 & 0,0 & 0,0 \\
\hline & 48 & 15,0 & 50,0 & 0,0 & 50,0 & 0,0 \\
\hline & 72 & 100,0 & 0,0 & 0,0 & 100,0 & 0,0 \\
\hline \multirow[t]{3}{*}{150} & 24 & 0,0 & 100,0 & 0,0 & 0,0 & 0,0 \\
\hline & 48 & 35,0 & 20,0 & 30,0 & 80,0 & 0,0 \\
\hline & 72 & 100,0 & 0,0 & 100,0 & 100,0 & 0,0 \\
\hline \multirow[t]{3}{*}{200} & 24 & 50,0 & 0,0 & 0,0 & 100,0 & 0,0 \\
\hline & 48 & 50,0 & 0,0 & 50,0 & 100,0 & 0,0 \\
\hline & 72 & 100,0 & 0,0 & 100,0 & 100,0 & 0,0 \\
\hline \multirow[t]{3}{*}{300} & 24 & 100,0 & 0,0 & 0,0 & 100,0 & 100,0 \\
\hline & 48 & 100,0 & 0,0 & 0,0 & 100,0 & 100,0 \\
\hline & 72 & 100,0 & 0,0 & 0,0 & 100,0 & 100,0 \\
\hline $\mathbf{P Z Q}^{\mathrm{b}, \mathrm{c}}$ & 24 & 100,0 & 30,0 & 10,0 & 70,0 & 90,0 \\
\hline
\end{tabular}

a Porcentagem em relação a 10 pares de vermes.

b Em DMSO 0,2\% no meio RPMI.

c Controle positivo: Praziquantel (PZQ $3 \mu \mathrm{g} / \mathrm{ml}$ ).

As alterações tegumentares foram avaliadas qualitativamente usando microscópio invertido com técnica de campo claro ou contraste de interferência.

Os valores correspondem a três experimentos feitos em triplicatas ou quadruplicatas. 
Tabela 28 - Alterações tegumentares em adultos de Schistosoma mansoni durante incubação com o extrato de Pothomorphe umbellata

\begin{tabular}{|c|c|c|c|c|c|c|}
\hline \multirow{3}{*}{$\begin{array}{l}\text { Extrato } \\
(\mu \mathrm{g} / \mathrm{ml})\end{array}$} & \multirow{3}{*}{$\begin{array}{l}\text { Tempo de } \\
\text { incubação } \\
\text { (h) }\end{array}$} & \multirow{3}{*}{$\begin{array}{c}\text { Mortalidade } \\
(\%)^{\mathrm{a}}\end{array}$} & \multicolumn{4}{|c|}{ Alterações tegumentares $(\%)^{a}$} \\
\hline & & & \multicolumn{2}{|c|}{ Leve } & \multicolumn{2}{|c|}{ Significativa } \\
\hline & & & Macho & Fêmea & Macho & Fêmea \\
\hline \multirow[t]{3}{*}{$\mathbf{0}$} & 24 & 0,0 & 0,0 & 0,0 & 0,0 & 0,0 \\
\hline & 48 & 0,0 & 0,0 & 0,0 & 0,0 & 0,0 \\
\hline & 72 & 0,0 & 0,0 & 0,0 & 0,0 & 0,0 \\
\hline \multirow[t]{3}{*}{40} & 24 & 0,0 & 0,0 & 0,0 & 0,0 & 0,0 \\
\hline & 48 & 0,0 & 30,0 & 0,0 & 0,0 & 0,0 \\
\hline & 72 & 0,0 & 70,0 & 0,0 & 0,0 & 0,0 \\
\hline \multirow[t]{3}{*}{50} & 24 & 0,0 & 0,0 & 0,0 & 0,0 & 0,0 \\
\hline & 48 & 0,0 & 60,0 & 0,0 & 10,0 & 0,0 \\
\hline & 72 & 0,0 & 70,0 & 0,0 & 30,0 & 0,0 \\
\hline \multirow[t]{3}{*}{60} & 24 & 0,0 & 20,0 & 0,0 & 0,0 & 0,0 \\
\hline & 48 & 0,0 & 50,0 & 0,0 & 50,0 & 0,0 \\
\hline & 72 & 100,0 & 0,0 & 0,0 & 100,0 & 0,0 \\
\hline \multirow[t]{3}{*}{75} & 24 & 0,0 & 20,0 & 10,0 & 0,0 & 0,0 \\
\hline & 48 & 0,0 & 40,0 & 70,0 & 60,0 & 30,0 \\
\hline & 72 & 100,0 & 0,0 & 0,0 & 100,0 & 100,0 \\
\hline \multirow[t]{3}{*}{100} & 24 & 0,0 & 80,0 & 100,0 & 20,0 & 0,0 \\
\hline & 48 & 100,0 & 0,0 & 0,0 & 100,0 & 100,0 \\
\hline & 72 & 100,0 & 0,0 & 0,0 & 100,0 & 100,0 \\
\hline \multirow[t]{3}{*}{150} & 24 & 100,0 & 0,0 & 0,0 & 100,0 & 100,0 \\
\hline & 48 & 100,0 & 0,0 & 0,0 & 100,0 & 100,0 \\
\hline & 72 & 100,0 & 0,0 & 0,0 & 100,0 & 100,0 \\
\hline $\mathbf{P Z Q}^{\mathrm{b}, \mathrm{c}}$ & 24 & 100,0 & 30,0 & 10,0 & 70,0 & 90,0 \\
\hline
\end{tabular}

a Porcentagem em relação a 10 pares de vermes.

${ }^{b}$ Em DMSO 0,2\% no meio RPMI.

c Controle positivo: Praziquantel (PZQ $3 \mu \mathrm{g} / \mathrm{ml}$ ).

As alterações tegumentares foram avaliadas qualitativamente usando microscópio invertido com técnica de campo claro ou contraste de interferência.

Os valores correspondem a três experimentos feitos em triplicatas ou quadruplicatas.

Não obstante a análise subjetiva para avaliar o efeito dos compostos e extratos no tegumento de Schistosoma mansoni, esse critério qualitativo é comumente empregado nos ensaios in vitro (RAMIREZ et al., 2007; XIAO et al., 2007; BRAGUINE et al., 2009; MAGALHÃES et al., 2009, 2010; KEISER et al., 2010; PARREIRA et al., 2010; NEVES et al., 2010; MORAES et al., 2011a, 2011b). Entretanto, por microscopia de luz, a observação morfológica do tegumento dos parasitas não permite avaliar os danos de forma detalhada.

Trabalho recente do nosso grupo descreve que as formas larvais de trematódeos (cercárias), incluindo a do S. mansoni, são autofluorescentes e, portanto, são visualizadas em microscopia confocal sem a presença de um fluoróforo marcador (MORAES et al., 2009). Além disso, quando os parasitas são fixados solução contendo ácido acétido, formaldeído e álcool (AFA, ver Materiais e Métodos item 4.7), a 
fluorescência é melhorada. Experimentos pilotos com as diferentes fases de S. mansoni (cercárias, esquistossômulos e adultos) mostraram que o ácido acético é fundamental para o melhoramento da fluorescência.

Nesse contexto, a fim de que seja realizada uma análise mais detalhada sobre o efeito dos compostos e extratos no tegumento de $S$. mansoni, os parasitas foram fixados em solução AFA e analisados com um microscópio confocal de varredura a laser (LSM 510 META, Zeiss). Comparativamente a vermes controles incubados apenas em meio RPMI, os danos nos tubérculos foram diretamente dependentes da concentração dos compostos ou extratos (Figuras 18-28). 

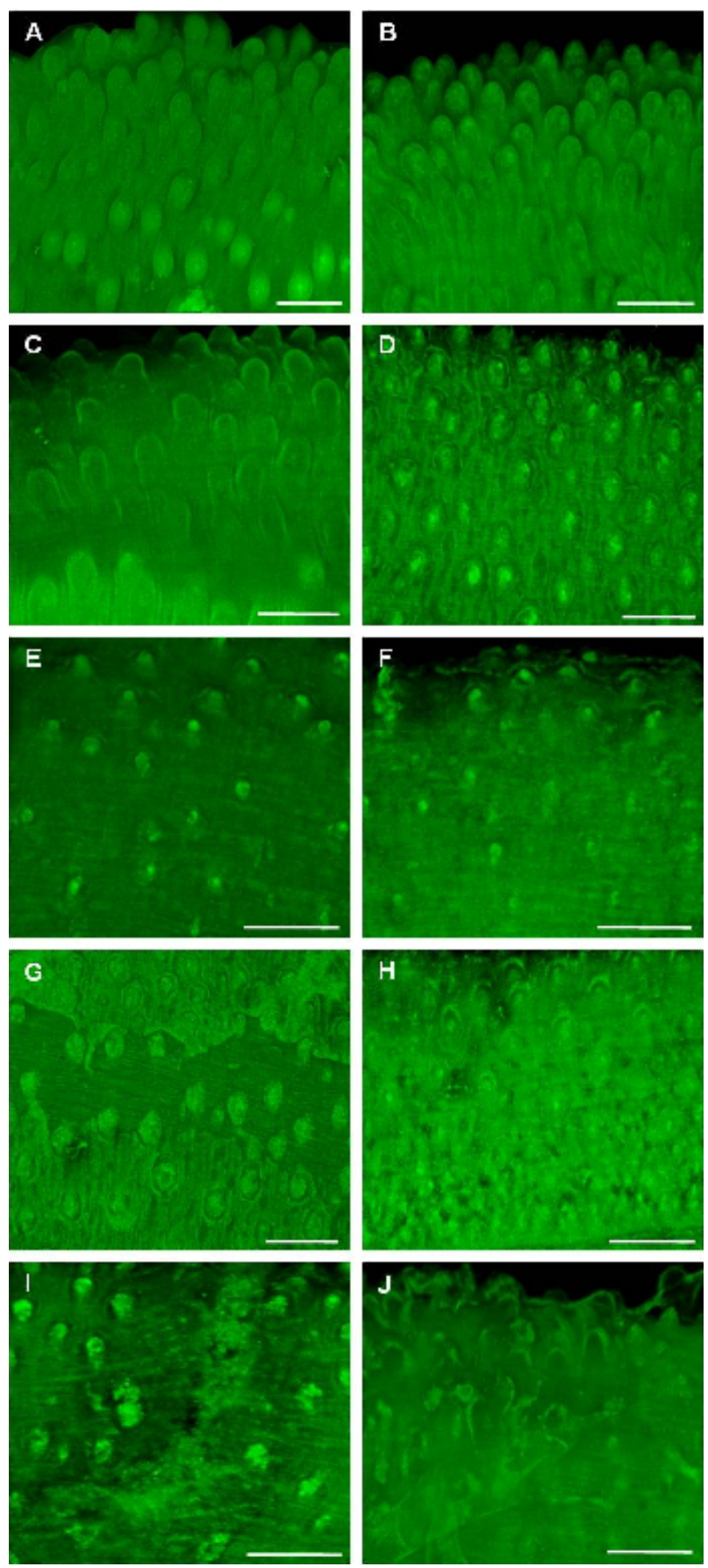
Figura 18. Efeito da amida piplartina no tegumento de machos de Schistosoma mansoni. Os pares de vermes acasalados (machos e fêmeas) foram incubados em meio RPMI contendo piplartina em diferentes concentrações. Após 24 horas ou ocorrência de morte, os parasitas foram fixados em solução AFA e analisados com microscópio confocal. A: controle, sem adição de piplartina. B: $2 \mu \mathrm{g} / \mathrm{ml}$. C: $5 \mu \mathrm{g} / \mathrm{ml}$. D: $10 \mu \mathrm{g} / \mathrm{ml}$. E: $25 \mu \mathrm{g} / \mathrm{ml}$. F: $50 \mu \mathrm{g} / \mathrm{ml}$. G: $100 \mu \mathrm{g} / \mathrm{ml}$. H: $125 \mu \mathrm{g} / \mathrm{ml}$. I: $150 \mu \mathrm{g} / \mathrm{ml}$. J: $200 \mu \mathrm{g} / \mathrm{ml}$. A-J: Imagens tridimensionais capturadas de microscópio confocal. Barras $=50 \mu \mathrm{m}$. 


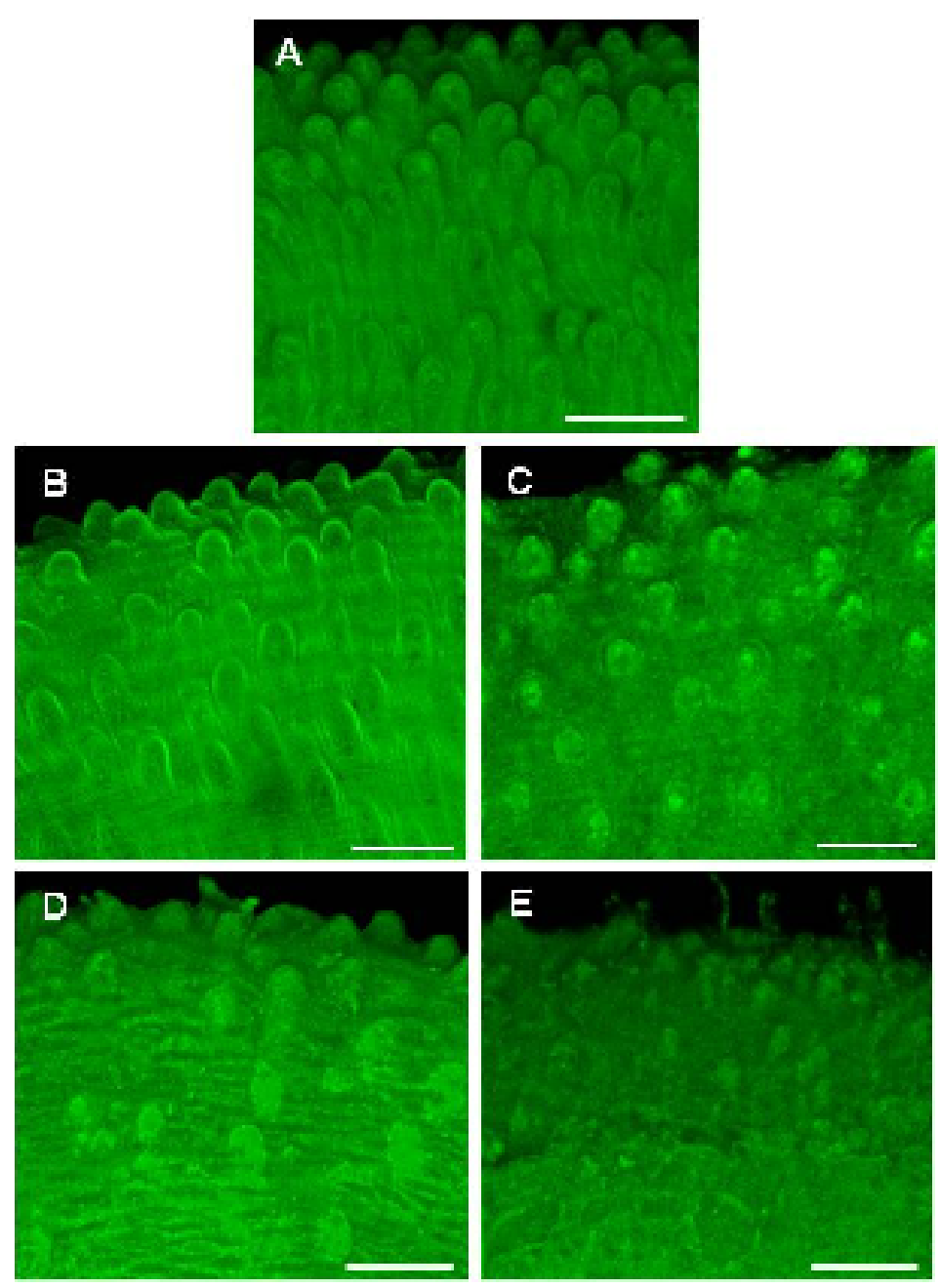

Figura 19. Efeito do peptídeo dermaseptina 01 no tegumento de machos de Schistosoma mansoni. Os pares de vermes acasalados (machos e fêmeas) foram incubados em meio RPMI contendo dermaseptina em diferentes concentrações. Após 120 horas ou ocorrência de morte, os parasitas foram fixados em solução AFA e analisados com microscópio confocal. A: controle, sem adição de dermaseptina. B: $50 \mu \mathrm{g} / \mathrm{ml}$. C: 100 $\mu \mathrm{g} / \mathrm{ml}$. D: $150 \mu \mathrm{g} / \mathrm{ml}$. E: $200 \mu \mathrm{g} / \mathrm{ml}$. A-E: Imagens tridimensionais capturadas de microscópio confocal. Barras $=50 \mu \mathrm{m}$. 

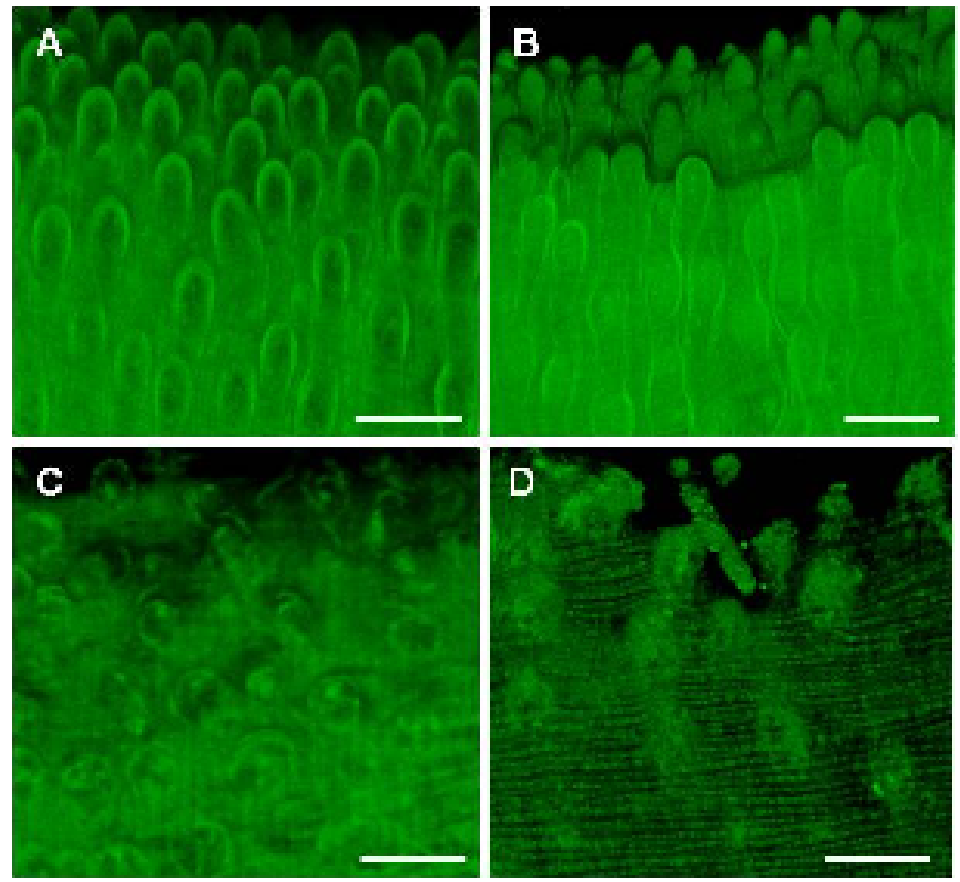

Figura 20. Efeito do alcaloide epiisopiloturina no tegumento de machos de Schistosoma mansoni. Os pares de vermes acasalados (machos e fêmeas) foram incubados em meio RPMI contendo epiisopiloturina em diferentes concentrações. Após 120 horas ou ocorrência de morte, os parasitas foram fixados em solução AFA e analisados com microscópio confocal. A: controle, sem adição de epiisopiloturina. B: $100 \mu \mathrm{g} / \mathrm{ml}$. C: 150 $\mu \mathrm{g} / \mathrm{ml}$. D: $200 \mu \mathrm{g} / \mathrm{ml}$. A-D: Imagens tridimensionais capturadas de microscópio confocal. Barras $=50 \mu \mathrm{m}$. 

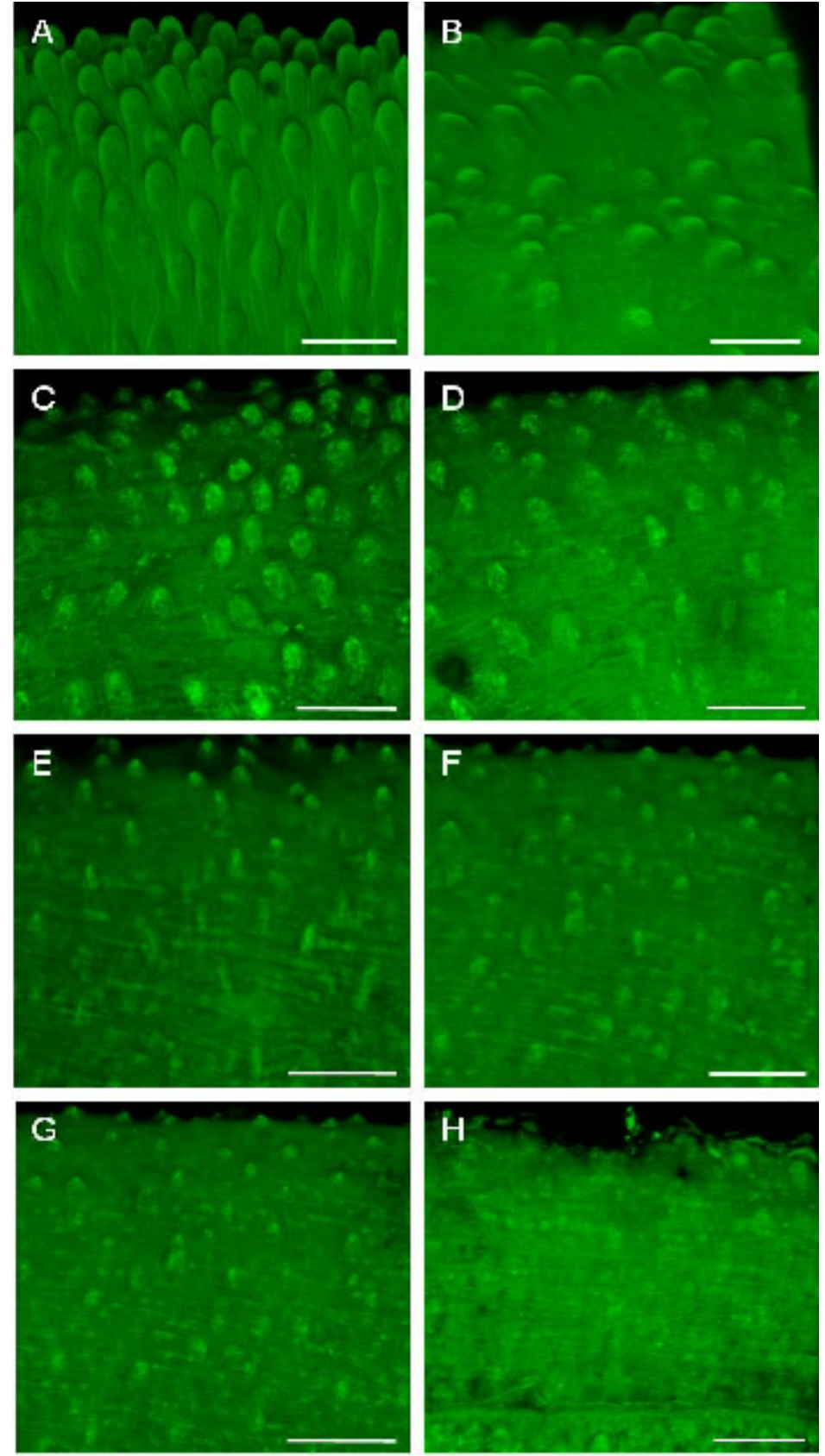

Figura 21. Efeito da amida piperina no tegumento de machos de Schistosoma mansoni. Os pares de vermes acasalados (machos e fêmeas) foram incubados em meio RPMI contendo piperina em diferentes concentrações. Após 24 horas, os parasitas foram fixados em solução AFA e monitorados com microscópio confocal A: controle, sem adição de piperina. B: $300 \mu \mathrm{g} / \mathrm{ml}$. C: $400 \mu \mathrm{g} / \mathrm{ml}$. D: $500 \mu \mathrm{g} / \mathrm{ml}$. E: $950 \mu \mathrm{g} / \mathrm{ml}$. F: 1250 $\mu \mathrm{g} / \mathrm{ml}$. G: $1500 \mu \mathrm{g} / \mathrm{ml}$. H: $1750 \mu \mathrm{g} / \mathrm{ml}$. A-H: Imagens tridimensionais capturadas de microscópio confocal. Barras $=50 \mu \mathrm{m}$. 


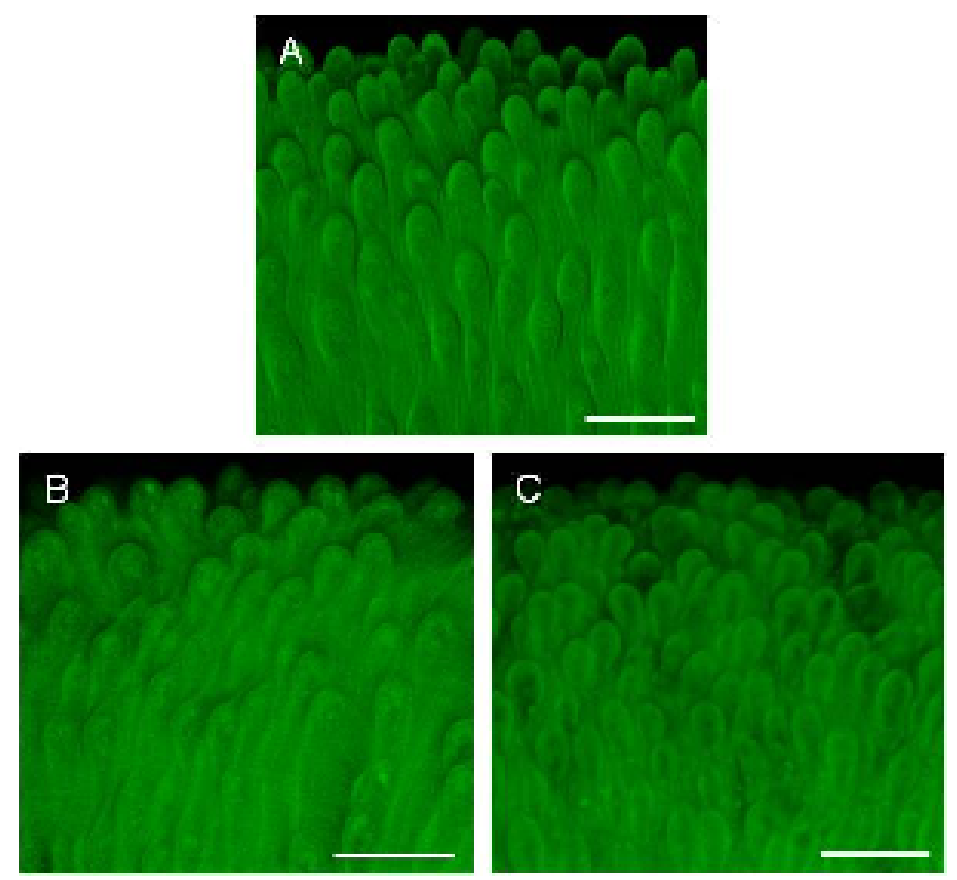

Figura 22. Efeito da lignana grandisina no tegumento de machos de Schistosoma mansoni. Os pares de vermes acasalados (machos e fêmeas) foram incubados em meio RPMI contendo grandisina em diferentes concentrações. Após 120 horas, os parasitas foram fixados em solução AFA e monitorados com microscópio confocal. A: controle, sem adição de grandisina. B: $1000 \mu \mathrm{g} / \mathrm{ml}$. C: $2000 \mu \mathrm{g} / \mathrm{ml}$. A-C: Imagens tridimensionais capturadas de microscópio confocal. Barras $=50 \mu \mathrm{m}$.
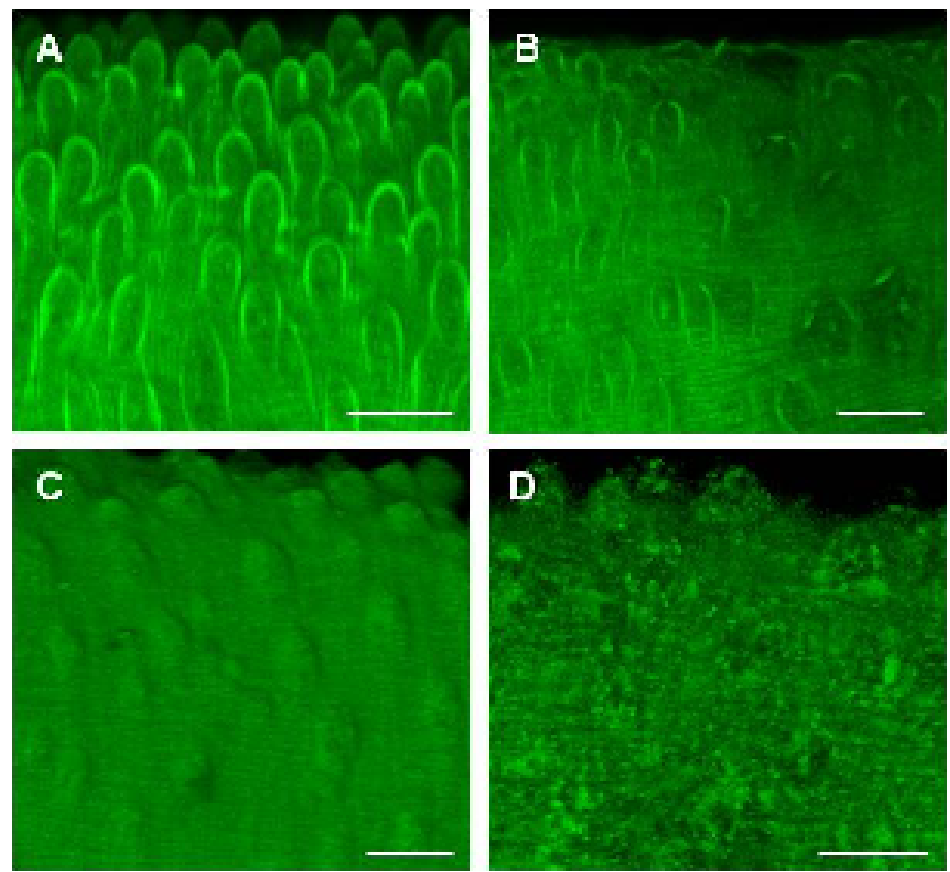

Figura 23. Efeito do extrato de Piper tuberculatum no tegumento de machos de Schistosoma mansoni. Os pares de vermes acasalados (machos e fêmeas) foram incubados em meio RPMI contendo extratos vegetais em diferentes concentrações. Após 120 horas ou ocorrência de morte, os parasitas foram fixados em solução AFA e monitorados com microscópio confocal. A: controle, sem adição de extrato. B: 25 $\mu \mathrm{g} / \mathrm{ml}$. C: $50 \mu \mathrm{g} / \mathrm{ml}$. D: $100 \mu \mathrm{g} / \mathrm{ml} \mathrm{A-D:} \mathrm{Imagens} \mathrm{tridimensionais} \mathrm{capturadas} \mathrm{de}$ microscópio confocal. Barras $=50 \mu \mathrm{m}$. 

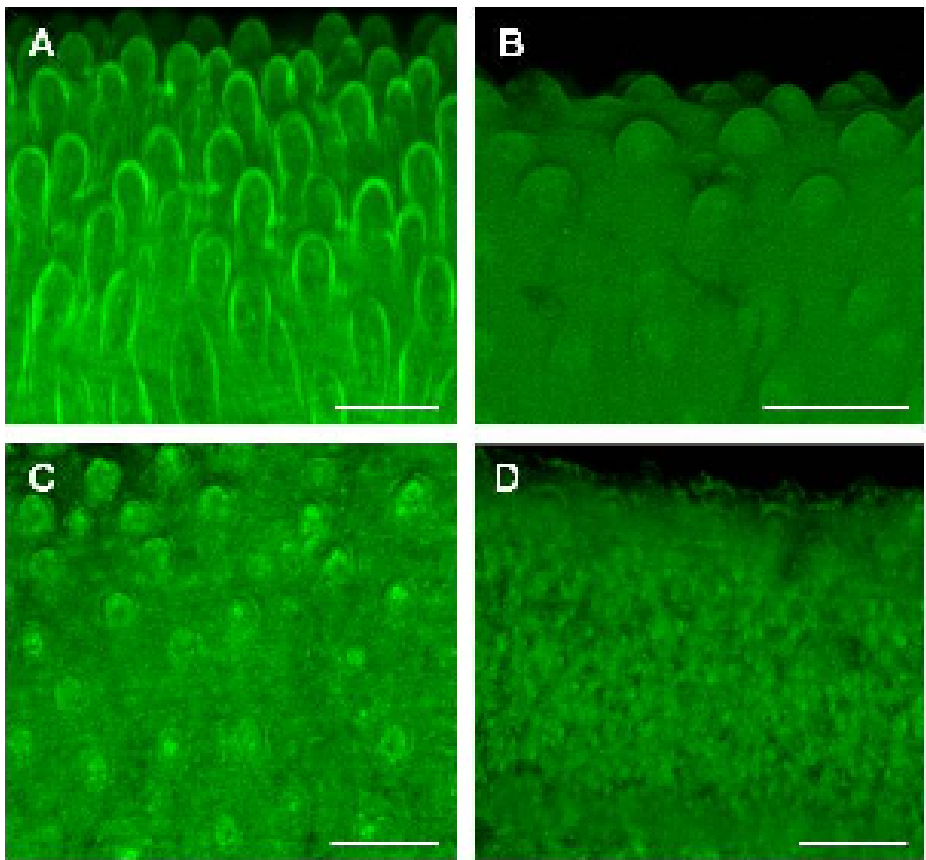

Figura 24. Efeito do extrato de Piper crassinervium no tegumento de machos de Schistosoma mansoni. Os pares de vermes acasalados (machos e fêmeas) foram incubados em meio RPMI contendo extratos vegetais em diferentes concentrações. Após 120 horas ou ocorrência de morte, os parasitas foram fixados em solução AFA e monitorados com microscópio confocal. A: controle, sem adição de extrato. B: 60 $\mu \mathrm{g} / \mathrm{ml}$. C: $100 \mu \mathrm{g} / \mathrm{ml}$. D: $200 \mu \mathrm{g} / \mathrm{ml}$ A-D: Imagens tridimensionais capturadas de microscópio confocal. Barras $=50 \mu \mathrm{m}$.
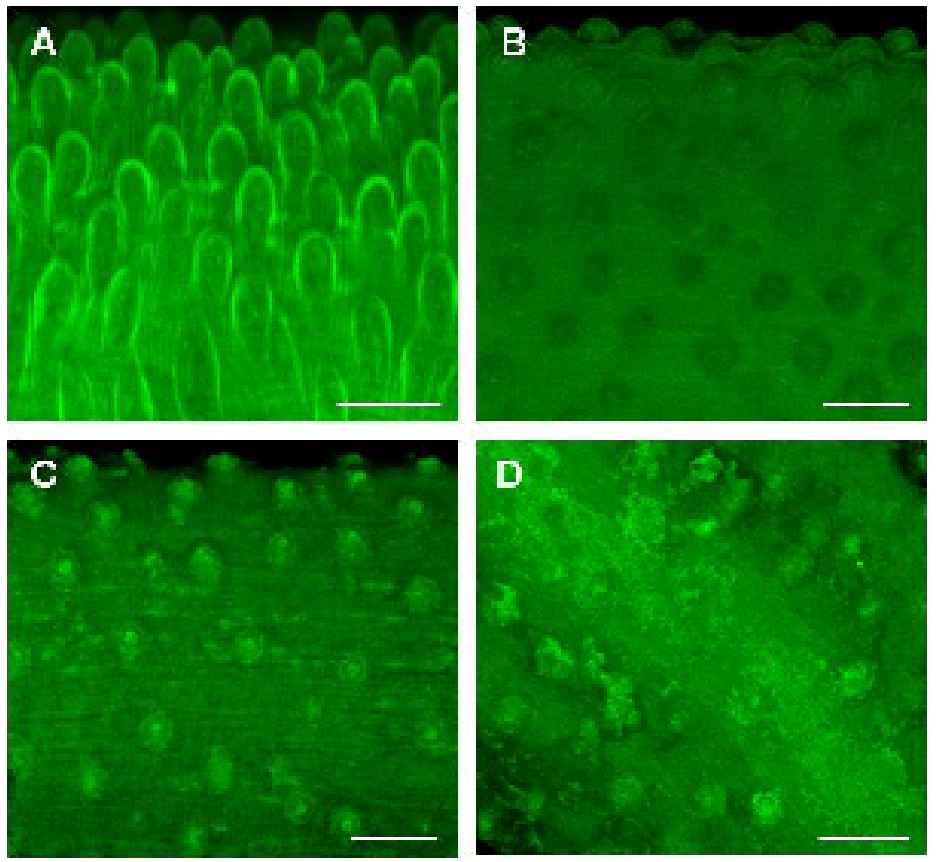

Figura 25. Efeito do extrato de Piper diospyrifolium no tegumento de machos de Schistosoma mansoni. Os pares de vermes acasalados (machos e fêmeas) foram incubados em meio RPMI contendo extratos vegetais em diferentes concentrações. Após 120 horas ou ocorrência de morte, os parasitas foram fixados em solução AFA e monitorados com microscópio confocal. A: controle, sem adição de extrato. B: 50 $\mu \mathrm{g} / \mathrm{ml}$. C: $100 \mu \mathrm{g} / \mathrm{ml}$. D: $200 \mu \mathrm{g} / \mathrm{ml} \mathrm{A-D:} \mathrm{Imagens} \mathrm{tridimensionais} \mathrm{capturadas} \mathrm{de}$ microscópio confocal. Barras $=50 \mu \mathrm{m}$. 

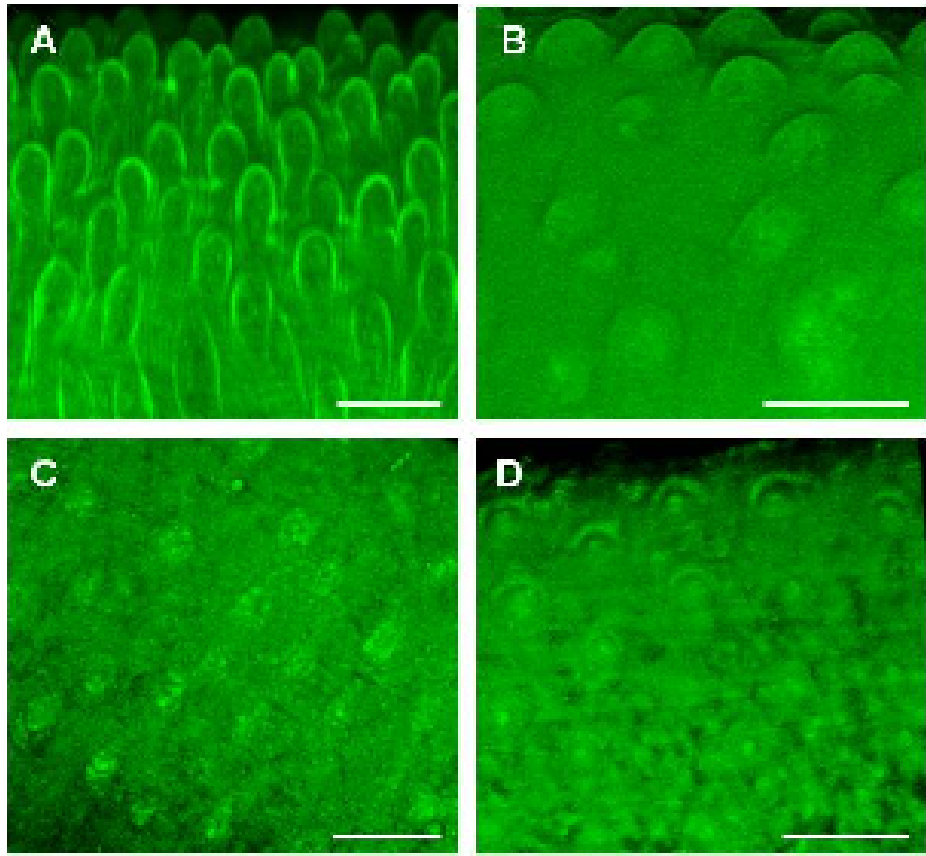

Figura 26. Efeito do extrato de Piper fuligineum no tegumento de machos de Schistosoma mansoni. Os pares de vermes acasalados (machos e fêmeas) foram incubados em meio RPMI contendo extratos vegetais em diferentes concentrações. Após 120 horas ou ocorrência de morte, os parasitas foram fixados em solução AFA e monitorados com microscópio confocal. A: controle, sem adição de extrato. B: $70 \mu \mathrm{g} / \mathrm{ml}$. C: $100 \mu \mathrm{g} / \mathrm{ml}$. D: $200 \mu \mathrm{g} / \mathrm{ml} \mathrm{A-D:} \mathrm{Imagens} \mathrm{tridimensionais} \mathrm{capturadas} \mathrm{de} \mathrm{microscópio} \mathrm{confocal.} \mathrm{Barras}$ $=50 \mu \mathrm{m}$.
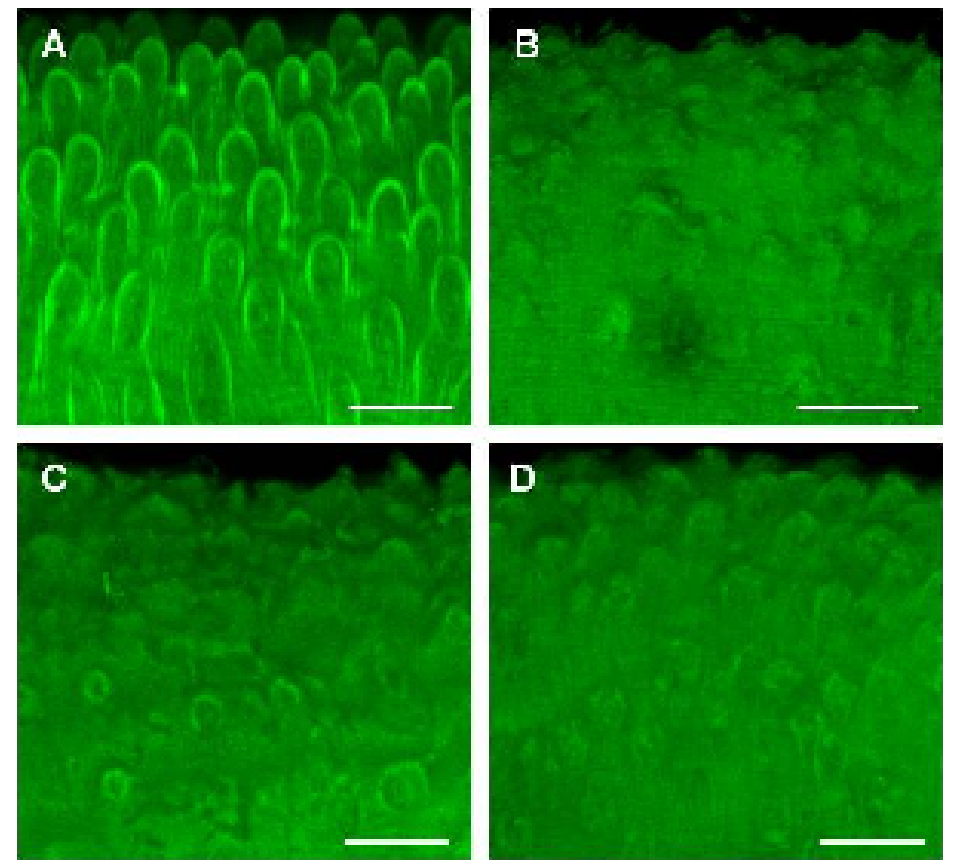

Figura 27. Efeito do extrato de Piper gaudichadianum no tegumento de machos de Schistosoma mansoni. Os pares de vermes acasalados (machos e fêmeas) foram incubados em meio RPMI contendo extratos vegetais em diferentes concentrações. Após 120 horas ou ocorrência de morte, os parasitas foram fixados em solução AFA e monitorados com microscópio confocal. A: controle, sem adição de extrato. B: 50 $\mu \mathrm{g} / \mathrm{ml}$. C: $100 \mu \mathrm{g} / \mathrm{ml}$. D: $150 \mu \mathrm{g} / \mathrm{ml} \mathrm{A-D:} \mathrm{Imagens} \mathrm{tridimensionais} \mathrm{capturadas} \mathrm{de}$ microscópio confocal. Barras $=50 \mu \mathrm{m}$. 

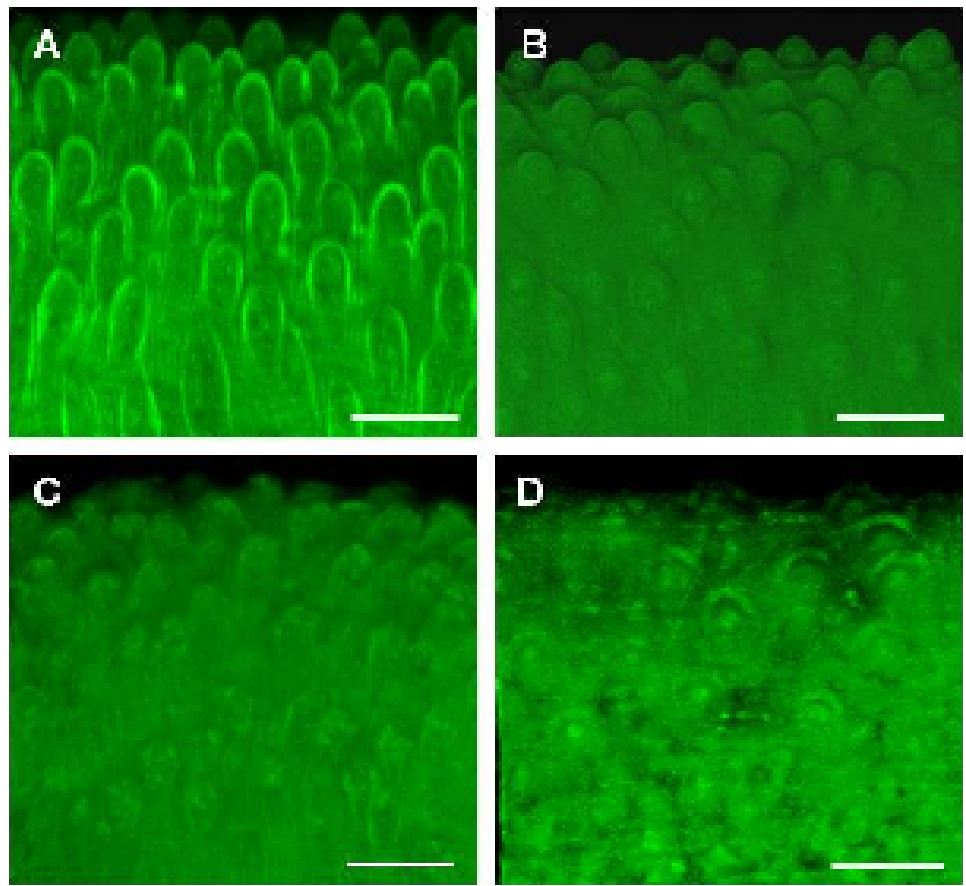

Figura 28. Efeito do extrato de Pophomorphe umbellata no tegumento de machos de Schistosoma mansoni. Os pares de vermes acasalados (machos e fêmeas) foram incubados em meio RPMI contendo extratos vegetais em diferentes concentrações. Após 120 horas ou ocorrência de morte, os parasitas foram fixados em solução AFA e monitorados com microscópio confocal. A: controle, sem adição de extrato. B: 40 $\mu \mathrm{g} / \mathrm{ml}$. C: $75 \mu \mathrm{g} / \mathrm{ml}$. D: $100 \mu \mathrm{g} / \mathrm{ml} \mathrm{A-D:} \mathrm{Imagens} \mathrm{tridimensionais} \mathrm{capturadas} \mathrm{de}$ microscópio confocal. Barras $=50 \mu \mathrm{m}$.

Em estudos com praziquantel, Willian et al. (2001) e Shuhua et al. (2000a) descreveram danos na superfície do corpo e nas ventosas de esquistosomos. Neste presente estudo, além da análise por microscopia confocal realizada no tegumento de $S$. mansoni, as ventosas (oral e ventral) dos parasitas foram monitoradas quando em presença de compostos e extratos. Os resultados indicaram que somente a amida piplartina causou alterações nas ventosas dos parasitas, principalmente nos helmintos machos. Os danos nas ventosas foram dependentes da concentração da piplartina e mais notadamente acima de $50 \mathrm{\mu g} / \mathrm{ml}$ (Figura 29). Alterações morfológicas no corpo de Schistosoma mansoni, sem afetar as ventosas das vermes fêmeas também foram assinaladas em estudos com praziquantel e artemeter (XIAO et al., 1985, 2000a). 

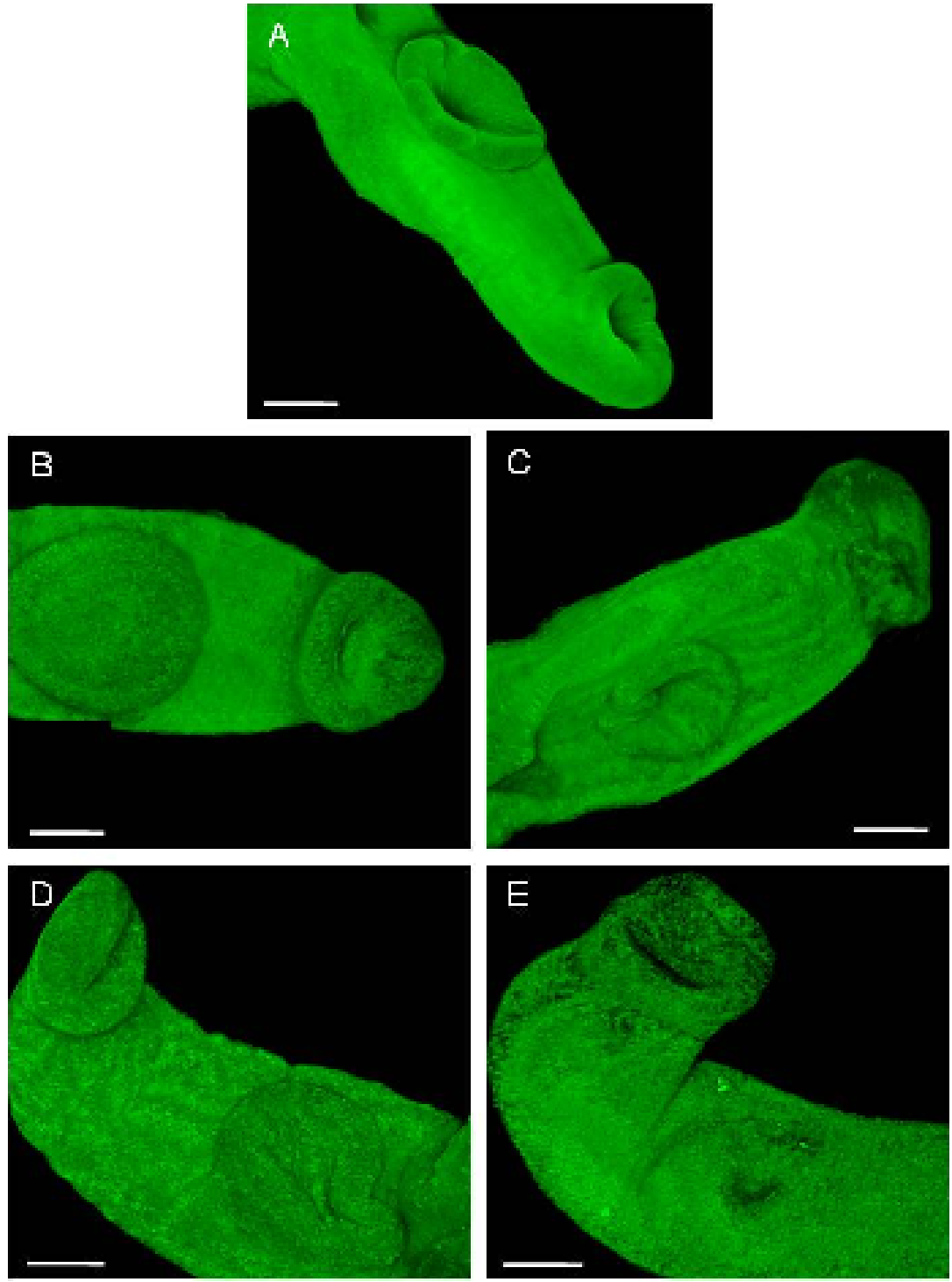

Figura 29. Efeito da amida piplartina nas ventosas de machos de Schistosoma mansoni. Os pares de vermes acasalados (machos e fêmeas) foram incubados em meio RPMI contendo piplartina. Após 24 horas, os parasitas machos foram fixados em solução AFA e as ventosas (oral e ventral) foram monitoradas com microscopia confocal A: controle, sem adição de piplartina. B: piplartina $50 \mu \mathrm{g} / \mathrm{ml}$. C: piplartina $100 \mu \mathrm{g} / \mathrm{ml}$. D: piplartina $150 \mu \mathrm{g} / \mathrm{ml}$. E: piplartina $200 \mu \mathrm{g} / \mathrm{ml}$. A-E: Imagens tridimensionais capturadas de microscópio confocal. Barras $=100 \mu \mathrm{m}$.

Nos últimos anos intensificou-se a busca por novos anti-helmínticos, mas progressos significativos não têm sido alcançados no desenvolvimento de novas técnicas para o estudo experimental de novos fármacos para a esquistossomose (RAMIREZ et al., 2007; KATZ, 2008) Como citado anteriormente, nas espécies de Schistosoma, os modelos experimentais para avaliação do efeito de drogas no tegumento são feitos de forma qualitativa (RAMIREZ et al., 2007; XIAO et al., 2007; BRAGUINE et al., 2009; MAGALHÃES et al., 2009, 2010; PARREIRA et al., 2010; NEVES et al., 2010). No 
presente estudo é proposto um modelo experimental que avalia quantitativamente o efeito de drogas no tegumento do Schistosoma mansoni.

Em Schistosoma mansoni, sabe-se que a topografia da superfície do corpo das fêmeas é mais simples do que a dos machos (RACE et al., 1971; HOCKLEY, 1973). A superfície é inteiramente escavada, não apresentando protuberâncias. Por outro lado, superfície dorsal dos vermes machos é coberta por numerosos tubérculos, enquanto que a superfície entre os tubérculos é composta por estrias planas e rasas, o que facilita a visualização de um eventual dano no tegumento (MACHADO-SILVA et al., 2008; XAVIER et al., 2010).

Com as imagens tridimensionais capturadas por microscopia confocal, os efeitos dos compostos e extratos no tegumento de adultos de $S$. mansoni foram analisados de forma quantitativa. Neste caso, os tubérculos na superfície dorsal de helmintos machos foram avaliados e contados em uma área de $20.000 \mu \mathrm{m}^{2}$ utilizando o software LSM Image Browser (Zeiss), como mostrado na Figura 6 do item 4.7 dos Materiais e Métodos.

Os resultados, no geral, revelaram que os compostos e extratos, exceto grandisina, causaram danos morfológicos nos tubérculos dos parasitas machos. Como indicado nas Figuras 30 e 31, os tubérculos foram afetados de maneira dose dependente e, comparativamente a controles incubados apenas em meio de cultura, os danos são significativos quando os vermes foram incubados com piplartina $25 \mu \mathrm{g} / \mathrm{ml}(\mathrm{P}<0,01)$, dermaseptina $75 \mu \mathrm{g} / \mathrm{ml}(P<0,05)$, epiisopiloturina $150 \mu \mathrm{g} / \mathrm{ml}(P<0,001)$ e piperina 300 $\mu \mathrm{g} / \mathrm{ml}(P<0,001)$; e os extratos de Piper tubercularum $10 \mu \mathrm{g} / \mathrm{ml}(P<0,05), P$. crassinervium $60 \mu \mathrm{g} / \mathrm{ml}(\mathrm{P}<0,05)$, $P$. diospyrifolium $50 \mu \mathrm{g} / \mathrm{ml}(\mathrm{P}<0,01), P$. fuligineum $70 \mu \mathrm{g} / \mathrm{ml}(P<0,05), P$. gaudichaudianum $50 \mu \mathrm{g} / \mathrm{ml}(P<0,001)$ e Pothomorphe umbellata $30 \mu \mathrm{g} / \mathrm{ml}(\mathrm{P}<0,05)$. 

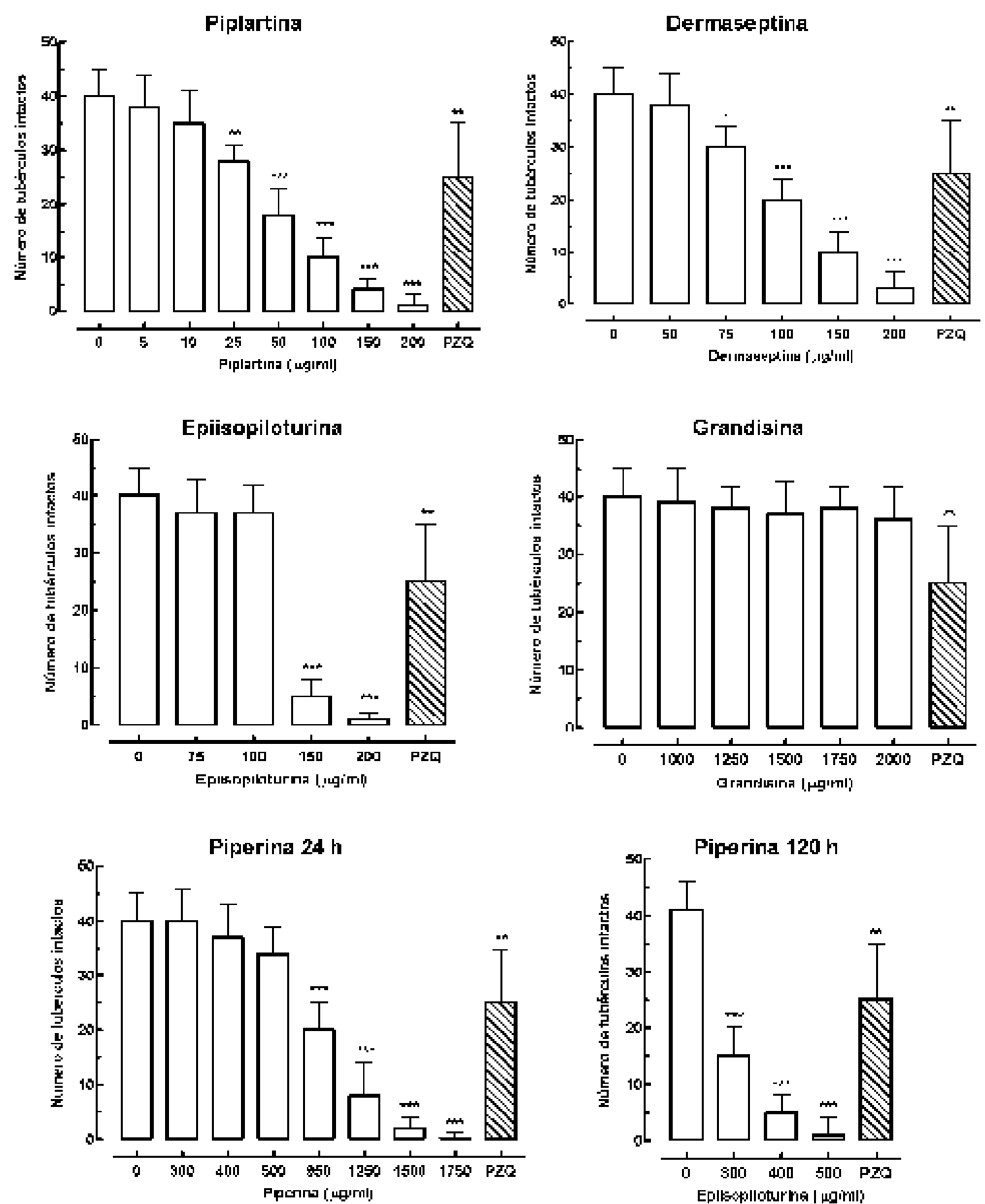

Figura 30. Efeito de compostos nos tubérculos de machos de Schistosoma mansoni. Os pares de vermes acasalados (machos e fêmeas) foram incubados em meio RPMI 1640 contendo os compostos nas concentrações indicadas. Após 120 horas ou ocorrência de morte, com exceção de piperina que foi somente nos tempos indicados, os parasitas foram fixados em solução AFA e monitorados com microscopia confocal. Indicados estão os tubérculos intactos, contados em pelo menos três áreas $\left(20.000 \mu \mathrm{m}^{2}\right)$ da superfície dorsal dos helmintos machos utilizando o software LSM Image Browser (Zeiss). Os valores são média de dez a quinze vermes de três ou quatro experimentos feitos em triplicatas ou quadruplicatas. As barras representam o desvio padrão da média.

Diferença significativa entre o controle negativo e os grupos tratados com compostos e praziquantel (PZQ $3 \mu \mathrm{g} / \mathrm{ml})$ : *(P<0,05), **(P<0,01), ***(P<0,001). 

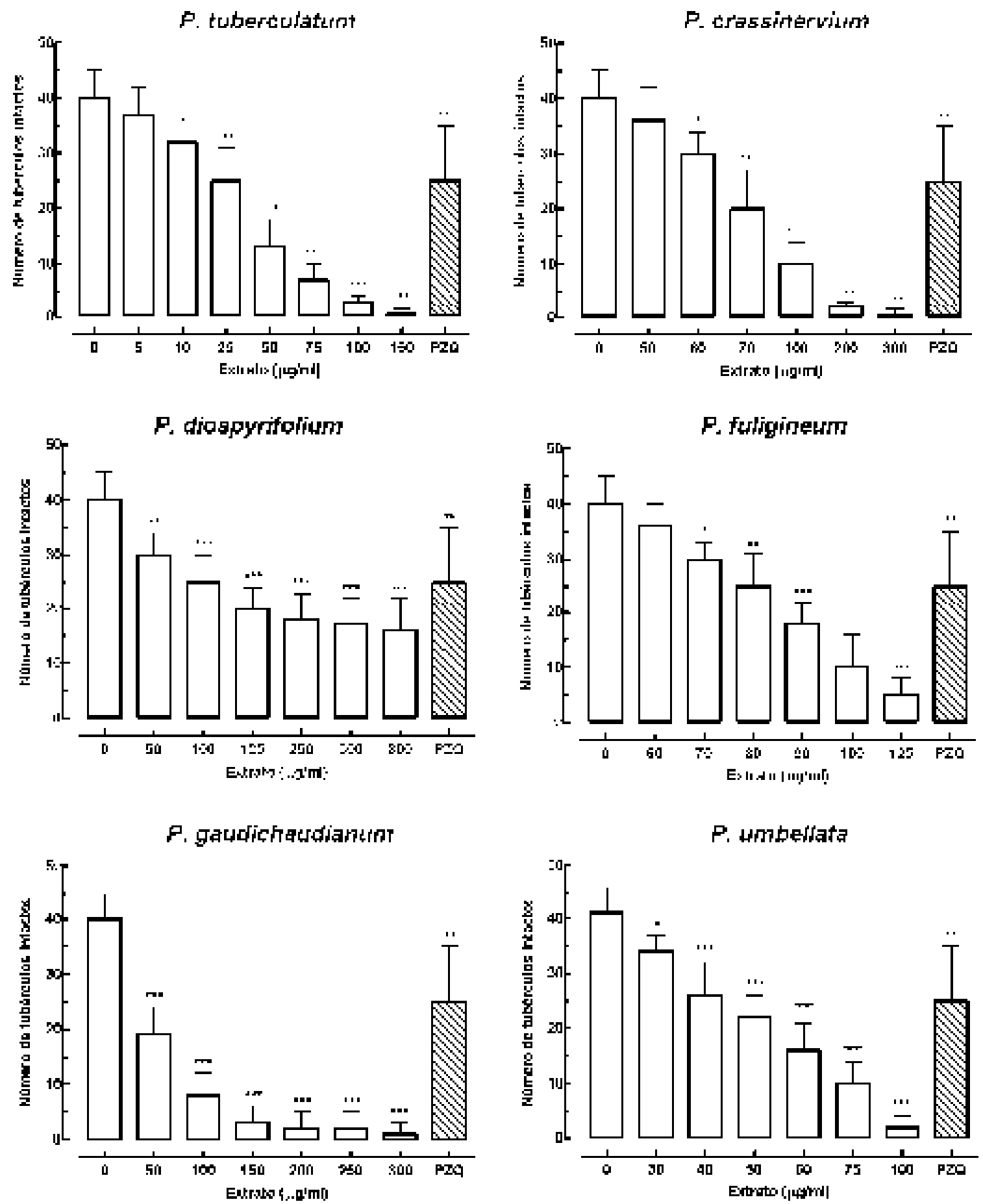

Figura 31. Efeito de extratos vegetais nos tubérculos de machos de Schistosoma mansoni. Os pares de vermes acasalados (machos e fêmeas) foram incubados em meio RPMI 1640 contendo os extratos nas concentrações indicadas. Após 120 horas ou ocorrência de morte, os parasitas foram fixados em solução AFA e monitorados com microscopia confocal. Indicados estão os tubérculos intactos, contados em pelo menos três áreas $\left(20.000 \mu \mathrm{m}^{2}\right.$ ) da superfície dorsal dos helmintos machos utilizando o software LSM Image Browser (Zeiss). Os valores são média de dez a quinze vermes de três ou quatro experimentos feitos em triplicatas ou quadruplicatas. As barras representam o desvio padrão da média.

Diferença significativa entre o controle negativo e os grupos tratados com extratos e praziquantel (PZQ $3 \mu \mathrm{g} / \mathrm{ml})$ : *(P<0,05), **(P<0,01), ***(P<0,001). 
$\mathrm{Na}$ maioria dos compostos e extratos vegetais ensaiados, a mortalidade dos parasitas adultos está associada à lesão no tegumento. De fato, as concentrações letais dos produtos naturais ensaiados estão muito próximas às concentrações que causaram danos no tegumento de adultos de S. mansoni. Por exemplo, o alcaloide epiisopiloturina possui efeito esquistossomicida nas concentrações superiores a $150 \mu \mathrm{g} / \mathrm{ml}$ (Figura 9), o que corrobora os danos morfológicos no tegumento (Figuras 20 e 30). Outro exemplo, agora com extrato vegetal, a ação letal aos adultos de $S$. mansoni em presença de extrato de folhas de Piper crassinervium foi notada com $60 \mu \mathrm{g} / \mathrm{ml}$ (Figura 13); sendo a mesma concentração que afetou os tubérculos dos vermes adultos (Figuras 24 e 31). Por outro lado, o efeito esquistossomicida da amida piplartina não está associado à lesão no tegumento. Em presença desta amida nota-se mortalidade de $100 \%$ com $3 \mu \mathrm{g} / \mathrm{ml}$ (Figura 4), mas os tubérculos foram significativamente afetados somente com piplartina $25 \mu \mathrm{g} / \mathrm{ml}$ (Figuras 18 e 30); ou seja, o tegumento foi afetado em uma concentração cerca de 8 vezes maior que a concentração letal. Como consta no ANEXO A, a morte dos adultos de $S$. mansoni em presença da amida piplartina está associada a outro(s) mecanismo(s), cujo modo de ação ainda é desconhecido (MORAES et al., 2011a). 
5.3 Efeito de compostos e extratos na oviposição de Schistosoma mansoni 
A patologia da esquistossomose está associada, principalmente, à presença de ovos de Schistosoma no tecido do hospedeiro (GRYSEELS et al., 2006; WILSON et al., 2007). Dessa forma, na busca de novos compostos para a terapêutica experimental deve-se considerar drogas supressoras, que acabem com a oviposição das fêmeas e, portanto, eliminem o principal agente patogênico, o ovo, além de interromper a transmissão da helmintose (KATZ, 2008). O objetivo desta parte do trabalho foi avaliar a capacidade reprodutiva de Schistosoma mansoni quando em presença de extratos e compostos em concentrações subletais.

A capacidade reprodutiva de S. mansoni foi avaliada pela observação dos efeitos da exposição no acasalamento e oviposição das fêmeas. Nos experimentos, os helmintos adultos acasalados foram incubados, in vitro, durante cinco dias em placas de 24 poços contendo compostos ou extratos em meio RPMI suplementado com $10 \%$ de soro a $37^{\circ} \mathrm{C}$, em atmosfera de $\mathrm{CO}_{2}$ a $5 \%$. O número de ovos foi contado diariamente com o auxílio de um estereomicroscópio (SANDERSON; BARTLETT; WHITFIELD, 2002; MITSUI; MIURA; AOKI, 2009; BRAGUINE et al., 2009; MORAES et al., 2011a, 2011b).

\subsubsection{Efeito de compostos e extratos, em concentrações subletais, na oviposição de adultos de Schistosoma mansoni}

A partir do monitoramento in vitro dos adultos acasalados de Schistosoma mansoni, foi possível constatar uma redução na oviposição do parasita de maneira dose dependente nas concentrações subletais dos compostos e extratos (Figuras 32 e 33). Nos vermes expostos, a contagem de ovos nos experimentos foi significativamente reduzida $(p<0,05$ a $p<0,001)$ e mais notadamente a partir do segundo dia, sendo exceções: grandisina e o extrato Piper gaudichaudianum, em todas as concentrações ensaiadas. Considerando a maior concentração subletal, comparativamente a controles incubados apenas em meio de cultura, no término do período de incubação o número de ovos foi significativamente menor com piplartina $2 \mu \mathrm{g} / \mathrm{ml}(p<0,001)$, dermaseptina $75 \mu \mathrm{g} / \mathrm{ml}$ $(p<0,001)$, epiisopiloturina $100 \mu \mathrm{g} / \mathrm{ml}(p<0,001)$, piperina $300 \mu \mathrm{g} / \mathrm{ml}(p<0,01)$ e com os extratos de Piper tuberculatum $3 \mu \mathrm{g} / \mathrm{ml}(p<0,001), \quad P$. crasssinervium $50 \mu \mathrm{g} / \mathrm{ml}$ $(p<0,001), P$. diospyrifolium $50 \mu \mathrm{g} / \mathrm{ml}(p<0,01), P$. fuligineum $40 \mu \mathrm{g} / \mathrm{ml}(p<0,001)$ e Pothomorphe umbellata $50 \mu \mathrm{g} / \mathrm{ml}(p<0,05)$. As contagens diárias de ovos eliminados pelas fêmeas de $S$. mansoni nas culturas contendo compostos ou extratos, em diferentes concentrações e tempo de incubação, são mostradas nas Figuras 32 e 33. 

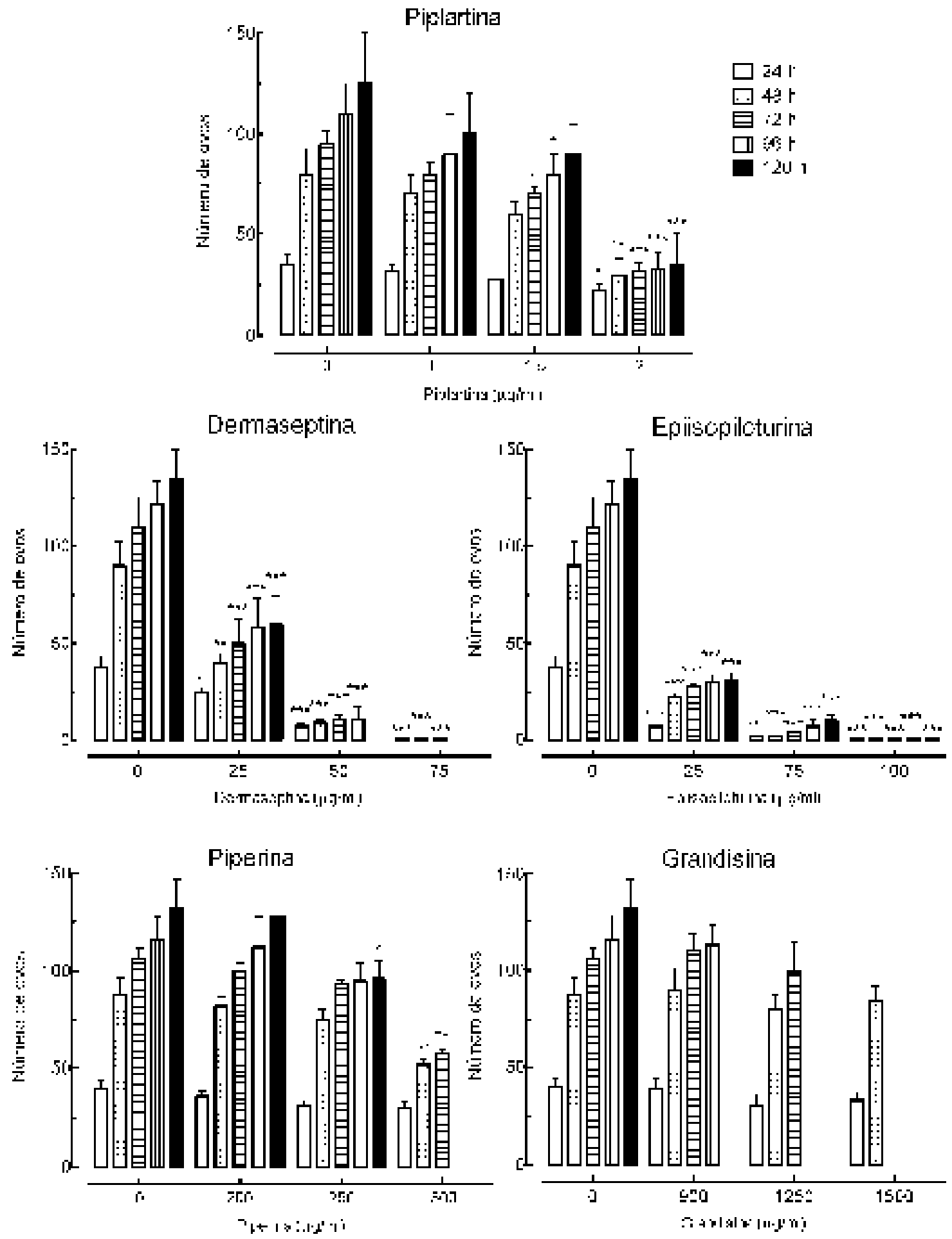

Figura 32. Efeito de compostos na oviposição de fêmeas de Schistosoma mansoni. Os pares de vermes acasalados (machos e fêmeas) foram incubados em meio RPMI contendo os compostos em diferentes concentrações. As contagens de ovos foram realizadas diariamente, nos tempos indicados, antes da separação dos casais de vermes ou da ação helminticida. Os valores são média de dez a quinze casais adultos acasalados, no total de três ou quatro experimentos feitos em triplicatas ou quadruplicatas. As barras representam o desvio padrão da média.

Diferença significativa entre o controle negativo e os compostos: $*(\mathrm{P}<0,05), * *(\mathrm{P}<$ $0,01), * * *(P<0,001)$. 

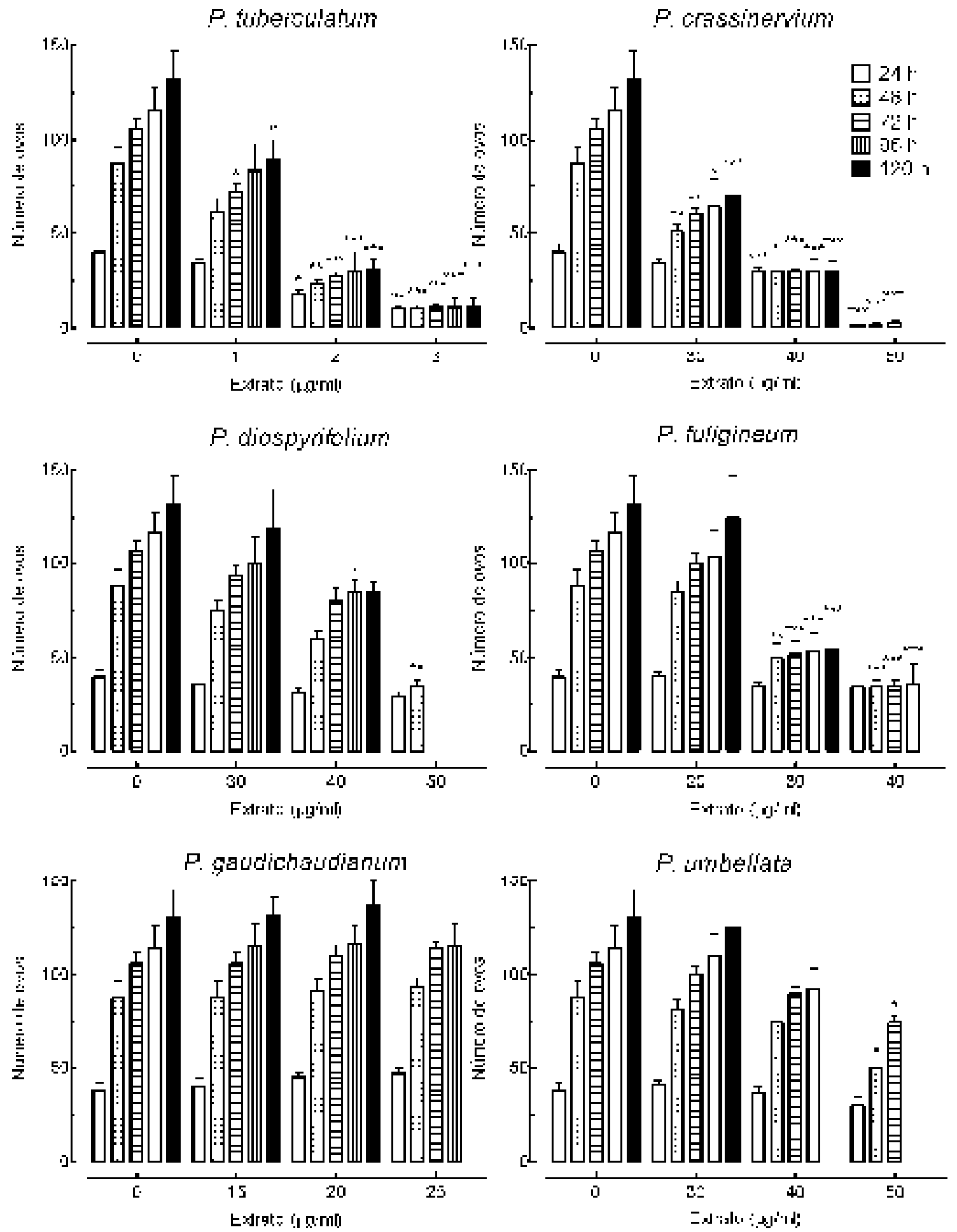

Figura 33. Efeito de extratos de plantas na oviposição de fêmeas de Schistosoma mansoni. Os pares de vermes acasalados (machos e fêmeas) foram incubados em meio RPMI contendo os extratos em diferentes concentrações. As contagens de ovos foram realizadas diariamente, nos tempos indicados, antes da separação dos casais de vermes ou da ação helminticida. Os valores são média de dez a quinze casais adultos acasalados, no total de três ou quatro experimentos feitos em triplicatas ou quadruplicatas. As barras representam o desvio padrão da média.

Diferença significativa entre o controle negativo e os extratos: *(P<0,05), **(P< $0,01), * * *(P<0,001)$. 
Alguns estudos in vitro também relatam a redução na oviposição de $S$. mansoni por compostos ou extratos vegetais. Por exemplo, curcumina $5 \mu \mathrm{M}$ a $10 \mu \mathrm{M}$ reduz o número de ovos em cerca de 40 a 50\% (MAGALHÃES et al., 2009). Os derivados de floroglucinóis, tais como aspidina, aspidinol, ácido flavaspídico e desaspidina, todos na concentração de $10 \mu \mathrm{M}$, causam inibição na oviposição em cerca 95\%, 58\%, 92\% e 91\%, respectivamente (MAGALHÃES et al., 2010). O extrato etanólico e compostos isolados de folhas de Zanthoxylum naranjillo Griseb (Rutaceae), popularmente conhecido como juva, naranjillo ou tembetari, reduziram a postura das fêmeas em cerca de $16 \%$ com 100 $\mu \mathrm{g} / \mathrm{ml}$ de extrato, e entre $13 \%$ e $30 \%$ com $100 \mu \mathrm{M}$ dos compostos (BRAGUINE et al., 2009). A redução no número de ovos também foi assinalada com artenusato e imidazolidinas, bem como com extratos de semente de Nigella sativa L. (Ranunculaceae), popularmente conhecido como aliprive, cominho ou diabo-na-mata, e rizoma de Zingiber officinale Roscoe (Zingiberaceae), popularmente conhecido como gengibre ou mangaratá (MOHAMED et al., 2005; SANDERSON; BARTLETT; WHITFIELD, 2002; MITSUI; MIURA; AOKI, 2009; NEVES et al., 2010).

Em geral, considerando os compostos e extratos vegetais utilizados neste estudo, dermaseptina $75 \mu \mathrm{g} / \mathrm{ml}$ e epiisopiloturina $100 \mu \mathrm{g} / \mathrm{ml}$ causaram uma redução de $100 \%$ no número de ovos; enquanto que os extratos de Piper crassinervium e $P$. tuberculatum reduziram, respectivamente, a oviposição em cerca de $98 \%$ e 92\%. A Tabela 29 mostra o percentual de redução da postura das fêmeas de S. mansoni em presença de compostos e extratos. 
Tabela 29 - Redução do número de ovos de Schistosoma mansoni durante incubação com compostos e extratos vegetais

\begin{tabular}{|c|c|c|c|}
\hline \multirow{2}{*}{ Compostos/Extratos } & \multicolumn{2}{|c|}{ Concentração $^{a}$} & \multirow{2}{*}{$\begin{array}{c}\text { Redução do } \\
\text { número de ovos }\end{array}$} \\
\hline & $\mu \mathrm{g} / \mathrm{ml}$ & $\mu \mathrm{M}$ & \\
\hline Dermaseptina 01 & 75 & 26,84 & $100 *$ \\
\hline Epiisopiloturina & 100 & 349,65 & 100 \\
\hline Piplartina & 2 & 6,3 & $\begin{array}{l}76,28 \\
\pm 4,17\end{array}$ \\
\hline Piperina & 300 & $1.051,45$ & $\begin{array}{l}46,73 \\
\pm 2,42\end{array}$ \\
\hline Grandisina & 1250 & $4.381,05$ & $\begin{array}{r}0,58 \\
\pm 0,5 \\
\end{array}$ \\
\hline Piper crassinervium & 50 & -- & $\begin{array}{l}97,97 \\
\pm 2,42\end{array}$ \\
\hline Piper tuberculatum & 3 & -- & $\begin{array}{l}92,03 \\
\pm 1,76\end{array}$ \\
\hline Piper fuligineum & 40 & -- & $\begin{array}{r}68,78 \\
\pm 5,42\end{array}$ \\
\hline Piper diospyrifolium & 50 & -- & $\begin{array}{c}60,01 \\
\pm 4,86\end{array}$ \\
\hline Pothomorphe umbellata & 50 & -- & $\begin{array}{l}30,08 \\
\pm 3,42\end{array}$ \\
\hline Piper gaudichaudianum & 25 & -- & $\begin{array}{c}0,31 \\
\pm 0,78\end{array}$ \\
\hline $\mathrm{PZQ}^{\mathrm{b}}$ & 1 & 3,2 & $\begin{array}{c}0,44 \\
\pm 0,18\end{array}$ \\
\hline
\end{tabular}

* Valores expressos em porcentagem em relação ao grupo controle, isto é, parasitas em DMSO $0,2 \%$ no meio RPMI.

a Concentração máxima com parasitas viáveis acasalados.

b Controle positivo: Praziquantel (PZQ).

Os valores são média \pm desvio padrão de, pelo menos, três experimentos realizados triplicatas.

Considerando a redução na oviposição dos esquistossomos em presença de compostos e extratos, experimentos adicionais foram realizados com a amida piplartina com o objetivo de verificar se a inibição na postura das fêmeas era reversível. Nos ensaios, os parasitas foram mantidos em presença de piplartina $2 \mu \mathrm{g} / \mathrm{ml}(6,3 \mu \mathrm{M})$ por até 48 horas. No dia subsequente, os vermes eram lavados três vezes em meio RPMI (procedimento este de forma cuidadosa para evitar a separação dos casais) e então incubados com o meio sem a presença do composto. Grupos controles, sem adição de piplartina, foram submetidos ao mesmo procedimento. O resultado obtido após 96 horas foi uma redução do número de ovos de $72,58 \% \pm 3,41 \%$ (média \pm desvio padrão de três experimentos independentes realizados em triplicatas, $n=10$ casais de vermes), um padrão semelhante aos experimentos feitos com a amida mantida constantemente nas culturas (Tabela 29). Dessa forma, constatou-se que a alteração na postura das fêmeas causada pela piplartina foi irreversível. 
A redução na oviposição pode ser causada por alterações no sistema reprodutivo de machos e/ou fêmeas. De fato, fármacos como a lovastatina, um potente inibidor de síntese endógena de colesterol, causam redução na oviposição de $S$. mansoni. Os estudos morfológicos de adultos expostos a lovastatina mostraram alterações degenerativas, sendo as principais no aparelho reprodutor, com redução e alteração dos folículos vitelínicos e do ovário das fêmeas e modificações nos testículos dos machos (ARAÚjO et al. 2002). Da mesma forma, a estreptozotocina, uma indutora de diabetes mellitus, afeta a oogênese e espermatogênese e pode causar esterilização dos esquistossomos. De fato, Hulstijn et al. (2003) mostraram que a estreptozotocina reduz a oviposição e causa alterações nos órgãos reprodutivos de machos e fêmeas de $S$. mansoni como atrofia dos lobos testiculares e ovários, além de inibição de espermatozóides e redução total ou parcial de ovócitos. Degeneração e atrofia em ovários e testículos de esquistossomos expostos ao artemeter também foram assinalados por Xiao e Catto (1989).

No presente estudo não foi verificado se os compostos ou extratos ensaiados causam alterações morfológicas nos órgãos reprodutivos. Entretanto, baseado na redução significativa do número de ovos, até mesmo de forma irreversível como mostrado com piplartina, é provável que os órgãos reprodutores dos vermes adultos de S. mansoni tenham sofrido alterações morfológicas e afetado e oogênese e/ou espermatogênese. 
5.4 Alterações na viabilidade e no tegumento de esquistossômulos de Schistosoma mansoni, com diferentes idades, em presença de compostos e extratos 
Quando as cercárias de esquistossomos penetram na pele dos hospedeiros definitivos sofrem nova organização que altera sua fisiologia e morfologia. Assim que se encontre nos tecidos da pele, o corpo cercariano transforma-se em esquistossômulo, um organismo já com aspecto vermiforme e que representa as formas jovens do helminto. Essa transformação é representada por respiração anaeróbica, perda da cauda, eliminação progressiva do glicocálix, esvaziamento das glândulas secretoras e reorganização do tegumento. Após a invasão da pele e transformação em esquistossômulo, o parasita necessita se deslocar da epiderme em direção à derme e sair por via sanguínea ou linfática. A permanência na pele se limita a dois ou três dias, ao fim dos quais o parasita acaba por penetrar em um vaso cutâneo e é passivamente arrastado pela circulação em direção ao coração e aos pulmões. Dependendo do hospedeiro, os esquistossômulos podem ser encontrados nos pulmões desde o quarto dia e alcançam as concentrações máximas entre o quinto e o sexto dia (RAMALHO-PINTO et al., 1974, 1975; STIREWALT, 1974; SKELLY e SHOEMAKER, 2000; MCKERROW e SALTER, 2002; SKELLY e ALAN WILSON, 2006; GOBERT; CHAI; MCMANUS, 2007).

$\mathrm{Na}$ busca de novos compostos para a terapêutica experimental deve-se considerar drogas profiláticas, que irão prevenir a infecção por agirem nas formas jovens do Schistosoma (RAMIREZ et al., 2007; KEISER, 2010). Esta parte do trabalho avaliou o efeito de compostos e extratos em esquistossômulos com diferentes idades. Os parâmetros avaliados foram: a) viabilidade; b) efeito no tegumento. Nos experimentos, os esquistossômulos com diferentes idades in vitro (recém-transformados, 1, 3, 5 e 7 dias) foram incubados durante cinco dias em placas de 96 poços contendo compostos ou extratos em meio 169 com DMSO $0,2 \%$ a $37{ }^{\circ} \mathrm{C}$, em atmosfera de $\mathrm{CO}_{2}$ a $5 \%$. Poços contendo somente meio de cultura ou meio com DMSO $0,2 \%$ foram usados como controle. As culturas foram monitoradas diariamente por até cinco dias, com o auxílio de um microscópio invertido. No término do período de incubação ou ocorrência de morte, os parasitas foram fixados e monitorados por microscópio confocal.

\subsubsection{Alterações na viabilidade de esquistossômulos, com diferentes idades, em presença de compostos e extratos}

O praziquantel, fármaco de escolha para o tratamento da esquistossomose, é eficaz somente contra as formas adultas de esquistossomo. De fato, os esquistossômulos apresentam baixa susceptibilidade ao praziquantel que, portanto, não é usado como fármaco profilático (SABAH et al., 1986; UTZINGER et al., 2003). No presente estudo, praziquantel $3 \mu \mathrm{g} / \mathrm{ml}(9,6 \mu \mathrm{M})$ foi utilizado como controle positivo nos ensaios com vermes adultos. Nos experimentos com esquistossômulos (recém-transformado, 1, 3, 5 e 7 dias de idade) foi testado praziquantel em diferentes concentrações. Como indicado na 
Tabela 30, o efeito anti-helmíntico do praziquantel foi notado somente nas concentrações iguais ou maiores que $150 \mu \mathrm{g} / \mathrm{ml}(480,15 \mu \mathrm{M})$ independente da idade dos esquistossômulos; a mortalidade no período de 24 horas ocorreu com praziquantel 200 $\mu \mathrm{g} / \mathrm{ml}(640,20 \mu \mathrm{M})$. 
Tabela 30 - Viabilidade de esquistossômulos de Schistosoma mansoni, com diferentes idades, em presença de praziquantel

\begin{tabular}{|c|c|c|c|c|c|c|}
\hline \multirow{3}{*}{$\begin{array}{c}\text { Praziquantel } \\
\qquad(\mu \mathrm{g} / \mathrm{ml})^{\mathrm{b}}\end{array}$} & \multirow{3}{*}{$\begin{array}{c}\text { Tempo de } \\
\text { incubação } \\
\text { (h) }\end{array}$} & \multicolumn{5}{|c|}{ Mortalidade (\%) } \\
\hline & & \multicolumn{5}{|c|}{ Idade dos esquistossômulos (dias) } \\
\hline & & $\mathbf{R T}^{\mathbf{c}}$ & 1 & 3 & 5 & 7 \\
\hline \multirow[t]{6}{*}{3} & 2 & 0,0 & 0,0 & 0,0 & 0,0 & 0,0 \\
\hline & 24 & 0,0 & 0,0 & 0,0 & 0,0 & 0,0 \\
\hline & 48 & 0,0 & 0,0 & 0,0 & 0,0 & 0,0 \\
\hline & 72 & 0,0 & 0,0 & 0,0 & 0,0 & 0,0 \\
\hline & 96 & 0,0 & 0,0 & 0,0 & 0,0 & 0,0 \\
\hline & 120 & 0,0 & 0,0 & 0,0 & 0,0 & 0,0 \\
\hline \multirow[t]{6}{*}{50} & 2 & 0,0 & 0,0 & 0,0 & 0,0 & 0,0 \\
\hline & 24 & 0,0 & 0,0 & 0,0 & 0,0 & 0,0 \\
\hline & 48 & 0,0 & 0,0 & 0,0 & 0,0 & 0,0 \\
\hline & 72 & 0,0 & 0,0 & 0,0 & 0,0 & 0,0 \\
\hline & 96 & 0,0 & 0,0 & 0,0 & 0,0 & 0,0 \\
\hline & 120 & 0,0 & 0,0 & 0,0 & 0,0 & 0,0 \\
\hline \multirow[t]{6}{*}{100} & 2 & 0,0 & 0,0 & 0,0 & 0,0 & 0,0 \\
\hline & 24 & 0,0 & 0,0 & 0,0 & 0,0 & 0,0 \\
\hline & 48 & 0,0 & 0,0 & 0,0 & 0,0 & 0,0 \\
\hline & 72 & 0,0 & 0,0 & 0,0 & 0,0 & 0,0 \\
\hline & 96 & 0,0 & 0,0 & 0,0 & 0,0 & 0,0 \\
\hline & 120 & 0,0 & 0,0 & 0,0 & 0,0 & 0,0 \\
\hline \multirow[t]{6}{*}{150} & 2 & 0,0 & 0,0 & 0,0 & 0,0 & 0,0 \\
\hline & 24 & 0,0 & 0,0 & 0,0 & 0,0 & 0,0 \\
\hline & 48 & 0,0 & 0,0 & 0,0 & 0,0 & 0,0 \\
\hline & 72 & 0,0 & 0,0 & 0,0 & 0,0 & 0,0 \\
\hline & 96 & 100,0 & 100,0 & 100,0 & 100,0 & 100,0 \\
\hline & 120 & 100,0 & 100,0 & 100,0 & 100,0 & 100,0 \\
\hline \multirow[t]{6}{*}{200} & 2 & 0,0 & 0,0 & 0,0 & 0,0 & 0,0 \\
\hline & 24 & 100,0 & 100,0 & 100,0 & 100,0 & 100,0 \\
\hline & 48 & 100,0 & 100,0 & 100,0 & 100,0 & 100,0 \\
\hline & 72 & 100,0 & 100,0 & 100,0 & 100,0 & 100,0 \\
\hline & 96 & 100,0 & 100,0 & 100,0 & 100,0 & 100,0 \\
\hline & 120 & 100,0 & 100,0 & 100,0 & 100,0 & 100,0 \\
\hline
\end{tabular}

a Porcentagem em relação a 450 esquistossômulos.

b Em DMSO 0,2\% no meio 169.

c RT: Esquistossômulo recém-transformado.

Os valores correspondem a três experimentos feitos em triplicatas.

Experimentos semelhantes, porém examinando um repertório mais amplo de compostos (piplartina, dermaseptina 01, epiisopiloturina, piperina e grandisina) e extratos etanólicos (obtidos de Piper tuberculatum, Piper crassinervium, Piper 
diospyrifolium, Piper fuligineum, Piper gaudichaudianum e Pothomorphe umbellata) foram realizados com os esquistossômulos de diferentes idades. A presença dos compostos e extratos nas culturas contendo as formas jovens de Schistosoma causou a morte dos parasitas, com exceção da lignana grandisina, sendo diretamente dependente da concentração, do tempo de incubação e da idade dos helmintos (Tabelas 31-41). O monitoramento, diariamente, das culturas por até 5 dias permitiu verificar que a mortalidade de $100 \%$ dos esquistossômulos de S. mansoni ocorreu com os compostos piplartina $2 \mu \mathrm{g} / \mathrm{ml}$, dermaseptina $100 \mu \mathrm{g} / \mathrm{ml}$, epiisopiloturina $300 \mu \mathrm{g} / \mathrm{ml}$ e piperina 100 $\mu \mathrm{g} / \mathrm{ml}$; e com os extratos de Piper tuberculatum $5 \mu \mathrm{g} / \mathrm{ml}, P$. crassinervium $5 \mu \mathrm{g} / \mathrm{ml} P$. diospyrifolium $10 \mu \mathrm{g} / \mathrm{ml}, P$. fuligineum $10 \mu \mathrm{g} / \mathrm{ml}, P$. gaudichaudianum $20 \mu \mathrm{g} / \mathrm{ml}$ e Pothomorphe umbellata $10 \mu \mathrm{g} / \mathrm{ml}$.

Considerando o efeito antiparasitário em esquistossômulos nas diferentes idades, notam-se diferenças entre os compostos e extratos. Por exemplo, no término do período de incubação, isto é, 120 horas, a mortalidade de 100\% dos esquistossômulos recémtransformados e dos esquistossômulos com 7 dias de idade, foi respectivamente: piplartina 2 e $2 \mu \mathrm{g} / \mathrm{ml}$; dermaseptina 150 e $100 \mu \mathrm{g} / \mathrm{ml}$; epiisopiloturina 400 e $300 \mu \mathrm{g} / \mathrm{ml}$; piperina 200 e $100 \mu \mathrm{g} / \mathrm{ml}$; Piper tuberculatum 15 e $10 \mu \mathrm{g} / \mathrm{ml}$, P. crassinervium 10 e 20 $\mu \mathrm{g} / \mathrm{ml} ; \quad P$. diospyrifolium 10 e $10 \mu \mathrm{g} / \mathrm{ml}$, $P$. fuligineum 10 e $20 \mu \mathrm{g} / \mathrm{ml}, \quad P$. gaudichaudianum 20 e $75 \mu \mathrm{g} / \mathrm{ml}$ e Pothomorphe umbellata 20 e $10 \mu \mathrm{g} / \mathrm{ml}$. A mortalidade dos esquistossômulos com diferentes idades, continuamente monitorada por até 120 horas, quando em presença dos compostos e extratos estão indicadas nas Tabelas 3141. 
Tabela 31 - Viabilidade de esquistossômulos de Schistosoma mansoni, com diferentes idades, em presença da amida piplartina

\begin{tabular}{|c|c|c|c|c|c|c|}
\hline \multirow{3}{*}{$\begin{array}{l}\text { Piplartina } \\
(\mu g / \mathrm{ml})^{b}\end{array}$} & \multirow{3}{*}{$\begin{array}{c}\text { Tempo de } \\
\text { incubação } \\
\text { (h) }\end{array}$} & \multicolumn{5}{|c|}{ Mortalidade (\%) } \\
\hline & & \multicolumn{5}{|c|}{ Idade dos esquistossômulos (dias) } \\
\hline & & $\mathbf{R T}^{\mathbf{c}}$ & 1 & 3 & 5 & 7 \\
\hline \multirow[t]{5}{*}{$\mathbf{0}$} & 24 & 0,0 & 0,0 & 0,0 & 0,0 & 0,0 \\
\hline & 48 & 0,0 & 0,0 & 0,0 & 0,0 & 0,0 \\
\hline & 72 & 0,0 & 0,0 & 0,0 & 0,0 & 0,0 \\
\hline & 96 & 0,0 & 0,0 & 0,0 & 0,0 & 0,0 \\
\hline & 120 & 0,0 & 0,0 & 0,0 & 0,0 & 0,0 \\
\hline \multirow[t]{5}{*}{2} & 24 & 0,0 & 0,0 & 0,0 & 0,0 & 0,0 \\
\hline & 48 & 0,0 & 0,0 & 0,0 & 0,0 & 0,0 \\
\hline & 72 & 0,0 & 0,0 & 0,0 & 0,0 & 0,0 \\
\hline & 96 & 100,0 & 100,0 & 100,0 & 100,0 & 100,0 \\
\hline & 120 & 100,0 & 100,0 & 100,0 & 100,0 & 100,0 \\
\hline \multirow[t]{5}{*}{5} & 24 & 0,0 & 0,0 & 0,0 & 0,0 & 0,0 \\
\hline & 48 & 0,0 & 0,0 & 0,0 & 0,0 & 100,0 \\
\hline & 72 & 0,0 & 0,0 & 0,0 & 100,0 & 100,0 \\
\hline & 96 & 100,0 & 100,0 & 100,0 & 100,0 & 100,0 \\
\hline & 120 & 100,0 & 100,0 & 100,0 & 100,0 & 100,0 \\
\hline \multirow[t]{5}{*}{10} & 24 & 0,0 & 0,0 & 0,0 & 0,0 & 0,0 \\
\hline & 48 & 0,0 & 0,0 & 0,0 & 0,0 & 100,0 \\
\hline & 72 & 0,0 & 0,0 & 100,0 & 100,0 & 100,0 \\
\hline & 96 & 100,0 & 100,0 & 100,0 & 100,0 & 100,0 \\
\hline & 120 & 100,0 & 100,0 & 100,0 & 100,0 & 100,0 \\
\hline \multirow[t]{5}{*}{20} & 24 & 0,0 & 0,0 & 0,0 & 0,0 & 0,0 \\
\hline & 48 & 0,0 & 0,0 & 0,0 & 100,0 & 100,0 \\
\hline & 72 & 0,0 & 0,0 & 100,0 & 100,0 & 100,0 \\
\hline & 96 & 100,0 & 100,0 & 100,0 & 100,0 & 100,0 \\
\hline & 120 & 100,0 & 100,0 & 100,0 & 100,0 & 100,0 \\
\hline \multirow[t]{5}{*}{25} & 24 & 100,0 & 100,0 & 100,0 & 100,0 & 100,0 \\
\hline & 48 & 100,0 & 100,0 & 100,0 & 100,0 & 100,0 \\
\hline & 72 & 100,0 & 100,0 & 100,0 & 100,0 & 100,0 \\
\hline & 96 & 100,0 & 100,0 & 100,0 & 100,0 & 100,0 \\
\hline & 120 & 100,0 & 100,0 & 100,0 & 100,0 & 100,0 \\
\hline $\mathbf{P Z Q}^{\mathrm{d}}$ & 24 & 100,0 & 100,0 & 100,0 & 100,0 & 100,0 \\
\hline
\end{tabular}

a Porcentagem em relação a 450 esquistossômulos.

${ }^{\text {b }}$ Em DMSO 0,2\% no meio 169.

c RT: Esquistossômulo recém-transformado.

${ }^{d}$ Controle positivo: Praziquantel (PZQ $250 \mu \mathrm{g} / \mathrm{ml}$ ).

Os valores correspondem a três experimentos feitos em triplicatas. 
Tabela 32 - Viabilidade de esquistossômulos de Schistosoma mansoni, com diferentes idades, em presença do peptídeo dermaseptina 01

\begin{tabular}{|c|c|c|c|c|c|c|}
\hline \multirow{3}{*}{$\begin{array}{l}\text { Dermaseptina } \\
\qquad(\mu \mathrm{g} / \mathrm{ml})\end{array}$} & \multirow{3}{*}{$\begin{array}{c}\text { Tempo de } \\
\text { incubação } \\
\text { (h) }\end{array}$} & \multicolumn{5}{|c|}{ Mortalidade $(\%)^{a}$} \\
\hline & & \multicolumn{5}{|c|}{ Idade dos esquistossômulos (dias) } \\
\hline & & $\mathbf{R T}^{\mathbf{b}}$ & 1 & 3 & 5 & 7 \\
\hline \multirow[t]{5}{*}{$\mathbf{0}$} & 24 & 0,0 & 0,0 & 0,0 & 0,0 & 0,0 \\
\hline & 48 & 0,0 & 0,0 & 0,0 & 0,0 & 0,0 \\
\hline & 72 & 0,0 & 0,0 & 0,0 & 0,0 & 0,0 \\
\hline & 96 & 0,0 & 0,0 & 0,0 & 0,0 & 0,0 \\
\hline & 120 & 0,0 & 0,0 & 0,0 & 0,0 & 0,0 \\
\hline \multirow[t]{5}{*}{100} & 24 & 0,0 & 0,0 & 0,0 & 0,0 & 0,0 \\
\hline & 48 & 0,0 & 0,0 & 0,0 & 0,0 & 0,0 \\
\hline & 72 & 0,0 & 0,0 & 0,0 & 0,0 & 0,0 \\
\hline & 96 & 0,0 & 0,0 & 0,0 & 0,0 & 0,0 \\
\hline & 120 & 0,0 & 0,0 & 51,7 & 80,8 & 100,0 \\
\hline \multirow[t]{5}{*}{150} & 24 & 0,0 & 0,0 & 0,0 & 0,0 & 0,0 \\
\hline & 48 & 0,0 & 0,0 & 0,0 & 0,0 & 0,0 \\
\hline & 72 & 0,0 & 0,0 & 0,0 & 0,0 & 0,0 \\
\hline & 96 & 0,0 & 0,0 & 0,0 & 0,0 & 100,0 \\
\hline & 120 & 100,0 & 100,0 & 100,0 & 100,0 & 100,0 \\
\hline \multirow[t]{5}{*}{200} & 24 & 0,0 & 0,0 & 0,0 & 0,0 & 0,0 \\
\hline & 48 & 0,0 & 0,0 & 0,0 & 0,0 & 0,0 \\
\hline & 72 & 0,0 & 0,0 & 0,0 & 0,0 & 56,6 \\
\hline & 96 & 0,0 & 0,0 & 0,0 & 100 & 100 \\
\hline & 120 & 100,0 & 100,0 & 100,0 & 100,0 & 100,0 \\
\hline \multirow[t]{5}{*}{250} & 24 & 0,0 & 0,0 & 0,0 & 0,0 & 0,0 \\
\hline & 48 & 0,0 & 0,0 & 0,0 & 0,0 & 0,0 \\
\hline & 72 & 0,0 & 0,0 & 0,0 & 100,0 & 100,0 \\
\hline & 96 & 50,0 & 53,3 & 80,0 & 100,0 & 100,0 \\
\hline & 120 & 100,0 & 100,0 & 100,0 & 100,0 & 100,0 \\
\hline \multirow[t]{5}{*}{300} & 24 & 100,0 & 100,0 & 100,0 & 100,0 & 100,0 \\
\hline & 48 & 100,0 & 100,0 & 100,0 & 100,0 & 100,0 \\
\hline & 72 & 100,0 & 100,0 & 100,0 & 100,0 & 100,0 \\
\hline & 96 & 100,0 & 100,0 & 100,0 & 100,0 & 100,0 \\
\hline & 120 & 100,0 & 100,0 & 100,0 & 100,0 & 100,0 \\
\hline$P Z Q^{d}$ & 24 & 100,0 & 100,0 & 100,0 & 100,0 & 100,0 \\
\hline
\end{tabular}

a Porcentagem em relação a 450 esquistossômulos.

${ }^{b}$ RT: Esquistossômulo recém-transformado.

${ }^{\text {c }}$ Controle positivo: Praziquantel (PZQ $200 \mu \mathrm{g} / \mathrm{ml}$ ).

Os valores correspondem a três experimentos feitos em triplicatas. 
Tabela 33 - Viabilidade de esquistossômulos de Schistosoma mansoni, com diferentes idades, em presença do alcaloide epiisopiloturina

\begin{tabular}{|c|c|c|c|c|c|c|}
\hline \multirow{3}{*}{$\begin{array}{l}\text { Epiisopiloturina } \\
\qquad(\mu \mathrm{g} / \mathrm{ml})^{\mathrm{b}}\end{array}$} & \multirow{3}{*}{$\begin{array}{c}\text { Tempo de } \\
\text { incubação } \\
\text { (h) }\end{array}$} & \multicolumn{5}{|c|}{ Mortalidade (\%) } \\
\hline & & \multicolumn{5}{|c|}{ Idade dos esquistossômulos (dias) } \\
\hline & & $\mathbf{R T}^{\mathbf{c}}$ & 1 & 3 & 5 & 7 \\
\hline \multirow[t]{5}{*}{$\mathbf{0}$} & 24 & 0,0 & 0,0 & 0,0 & 0,0 & 0,0 \\
\hline & 48 & 0,0 & 0,0 & 0,0 & 0,0 & 0,0 \\
\hline & 72 & 0,0 & 0,0 & 0,0 & 0,0 & 0,0 \\
\hline & 96 & 0,0 & 0,0 & 0,0 & 0,0 & 0,0 \\
\hline & 120 & 0,0 & 0,0 & 0,0 & 0,0 & 0,0 \\
\hline \multirow[t]{5}{*}{300} & 24 & 0,0 & 0,0 & 0,0 & 0,0 & 0,0 \\
\hline & 48 & 0,0 & 0,0 & 0,0 & 0,0 & 0,0 \\
\hline & 72 & 0,0 & 0,0 & 0,0 & 0,0 & 0,0 \\
\hline & 96 & 0,0 & 0,0 & 0,0 & 0,0 & 0,0 \\
\hline & 120 & 0,0 & 0,0 & 0,0 & 0,0 & 100,0 \\
\hline \multirow[t]{5}{*}{350} & 24 & 0,0 & 0,0 & 0,0 & 0,0 & 0,0 \\
\hline & 48 & 0,0 & 0,0 & 0,0 & 0,0 & 0,0 \\
\hline & 72 & 0,0 & 0,0 & 0,0 & 0,0 & 0,0 \\
\hline & 96 & 0,0 & 0,0 & 0,0 & 0,0 & 0,0 \\
\hline & 120 & 0,0 & 0,0 & 0,0 & 100,0 & 100,0 \\
\hline \multirow[t]{5}{*}{400} & 24 & 0,0 & 0,0 & 0,0 & 0,0 & 0,0 \\
\hline & 48 & 0,0 & 0,0 & 0,0 & 0,0 & 0,0 \\
\hline & 72 & 0,0 & 0,0 & 0,0 & 0,0 & 0,0 \\
\hline & 96 & 100,0 & 100,0 & 100,0 & 100,0 & 100,0 \\
\hline & 120 & 100,0 & 100,0 & 100,0 & 100,0 & 100,0 \\
\hline \multirow[t]{5}{*}{500} & 24 & 0,0 & 0,0 & 0,0 & 0,0 & 0,0 \\
\hline & 48 & 0,0 & 0,0 & 0,0 & 0,0 & 0,0 \\
\hline & 72 & 0,0 & 0,0 & 0,0 & 100,0 & 100,0 \\
\hline & 96 & 100,0 & 100,0 & 100,0 & 100,0 & 100,0 \\
\hline & 120 & 100,0 & 100,0 & 100,0 & 100,0 & 100,0 \\
\hline $\mathbf{P Z Q}^{\mathbf{d}}$ & 24 & 100,0 & 100,0 & 100,0 & 100,0 & 100,0 \\
\hline
\end{tabular}

a Porcentagem em relação a 450 esquistossômulos.

${ }^{\mathrm{b}}$ Em DMSO 0,2\% no meio 169.

c RT: Esquistossômulo recém-transformado.

${ }^{d}$ Controle positivo: Praziquantel (PZQ $200 \mu \mathrm{g} / \mathrm{ml}$ ).

Os valores correspondem a três experimentos feitos em triplicatas. 
Tabela 34 - Viabilidade de esquistossômulos de Schistosoma mansoni, com diferentes idades, em presença da amida piperina

\begin{tabular}{|c|c|c|c|c|c|c|}
\hline \multirow{3}{*}{$\begin{array}{l}\text { Piperina } \\
(\mu \mathrm{g} / \mathrm{ml})^{\mathrm{b}}\end{array}$} & \multirow{3}{*}{$\begin{array}{c}\text { Tempo de } \\
\text { incubação } \\
\text { (h) }\end{array}$} & \multicolumn{5}{|c|}{ Mortalidade $(\%)^{\mathrm{a}}$} \\
\hline & & \multicolumn{5}{|c|}{ Idade dos esquistossômulos (dias) } \\
\hline & & $\mathbf{R T}^{\mathbf{c}}$ & 1 & 3 & 5 & 7 \\
\hline \multirow[t]{5}{*}{$\mathbf{0}$} & 24 & 0,0 & 0,0 & 0,0 & 0,0 & 0,0 \\
\hline & 48 & 0,0 & 0,0 & 0,0 & 0,0 & 0,0 \\
\hline & 72 & 0,0 & 0,0 & 0,0 & 0,0 & 0,0 \\
\hline & 96 & 0,0 & 0,0 & 0,0 & 0,0 & 0,0 \\
\hline & 120 & 0,0 & 0,0 & 0,0 & 0,0 & 0,0 \\
\hline \multirow[t]{5}{*}{100} & 24 & 0,0 & 0,0 & 0,0 & 0,0 & 0,0 \\
\hline & 48 & 0,0 & 0,0 & 0,0 & 0,0 & 0,0 \\
\hline & 72 & 0,0 & 0,0 & 0,0 & 0,0 & 0,0 \\
\hline & 96 & 0,0 & 0,0 & 0,0 & 0,0 & 100,0 \\
\hline & 120 & 0,0 & 0,0 & 0,0 & 100,0 & 100,0 \\
\hline \multirow[t]{5}{*}{200} & 24 & 0,0 & 0,0 & 0,0 & 0,0 & 0,0 \\
\hline & 48 & 0,0 & 0,0 & 0,0 & 0,0 & 0,0 \\
\hline & 72 & 0,0 & 0,0 & 0,0 & 100,0 & 100,0 \\
\hline & 96 & 100,0 & 100,0 & 100,0 & 100,0 & 100,0 \\
\hline & 120 & 100,0 & 100,0 & 100,0 & 100,0 & 100,0 \\
\hline \multirow[t]{5}{*}{300} & 24 & 0,0 & 0,0 & 0,0 & 0,0 & 0,0 \\
\hline & 48 & 0,0 & 0,0 & 4,4 & 0,0 & 3,7 \\
\hline & 72 & 100,0 & 100,0 & 100,0 & 100,0 & 100,0 \\
\hline & 96 & 100,0 & 100,0 & 100,0 & 100,0 & 100,0 \\
\hline & 120 & 100,0 & 100,0 & 100,0 & 100,0 & 100,0 \\
\hline \multirow[t]{5}{*}{400} & 24 & 5,7 & 0,0 & 3,7 & 5,3 & 100,0 \\
\hline & 48 & 100,0 & 100,0 & 100,0 & 100,0 & 100,0 \\
\hline & 72 & 100,0 & 100,0 & 100,0 & 100,0 & 100,0 \\
\hline & 96 & 100,0 & 100,0 & 100,0 & 100,0 & 100,0 \\
\hline & 120 & 100,0 & 100,0 & 100,0 & 100,0 & 100,0 \\
\hline \multirow[t]{5}{*}{500} & 24 & 100,0 & 100,0 & 100,0 & 100,0 & 100,0 \\
\hline & 48 & 100,0 & 100,0 & 100,0 & 100,0 & 100,0 \\
\hline & 72 & 100,0 & 100,0 & 100,0 & 100,0 & 100,0 \\
\hline & 96 & 100,0 & 100,0 & 100,0 & 100,0 & 100,0 \\
\hline & 120 & 100,0 & 100,0 & 100,0 & 100,0 & 100,0 \\
\hline $\mathbf{P Z Q}^{\mathbf{d}}$ & 24 & 100,0 & 100,0 & 100,0 & 100,0 & 100,0 \\
\hline
\end{tabular}

a Porcentagem em relação a 450 esquistossômulos.

${ }^{\mathrm{b}}$ Em DMSO 0,2\% no meio 169.

c RT: Esquistossômulo recém-transformado.

d Controle positivo: Praziquantel (PZQ $200 \mu \mathrm{g} / \mathrm{ml}$ ).

Os valores correspondem a três experimentos feitos em triplicatas. 
Tabela 35 - Viabilidade de esquistossômulos de Schistosoma mansoni, com diferentes idades, em presença da lignana grandisina

\begin{tabular}{|c|c|c|c|c|c|c|}
\hline \multirow{3}{*}{$\begin{array}{c}\text { Grandisina } \\
(\mu \mathrm{g} / \mathrm{ml})^{\mathrm{b}}\end{array}$} & \multirow{3}{*}{$\begin{array}{c}\text { Tempo de } \\
\text { incubação } \\
\text { (h) }\end{array}$} & \multicolumn{5}{|c|}{ Mortalidade (\%) } \\
\hline & & \multicolumn{5}{|c|}{ Idade dos esquistossômulos (dias) } \\
\hline & & $\mathbf{R T}^{\mathbf{c}}$ & $\mathbf{1}$ & 3 & 5 & 7 \\
\hline \multirow[t]{5}{*}{0} & 24 & 0,0 & 0,0 & 0,0 & 0,0 & 0,0 \\
\hline & 48 & 0,0 & 0,0 & 0,0 & 0,0 & 0,0 \\
\hline & 72 & 0,0 & 0,0 & 0,0 & 0,0 & 0,0 \\
\hline & 96 & 0,0 & 0,0 & 0,0 & 0,0 & 0,0 \\
\hline & 120 & 0,0 & 0,0 & 0,0 & 0,0 & 0,0 \\
\hline \multirow[t]{5}{*}{1000} & 24 & 0,0 & 0,0 & 0,0 & 0,0 & 0,0 \\
\hline & 48 & 0,0 & 0,0 & 0,0 & 0,0 & 0,0 \\
\hline & 72 & 0,0 & 0,0 & 0,0 & 0,0 & 0,0 \\
\hline & 96 & 0,0 & 0,0 & 0,0 & 0,0 & 0,0 \\
\hline & 120 & 0,0 & 0,0 & 0,0 & 0,0 & 0,0 \\
\hline \multirow[t]{5}{*}{1250} & 24 & 0,0 & 0,0 & 0,0 & 0,0 & 0,0 \\
\hline & 48 & 0,0 & 0,0 & 0,0 & 0,0 & 0,0 \\
\hline & 72 & 0,0 & 0,0 & 0,0 & 0,0 & 0,0 \\
\hline & 96 & 0,0 & 0,0 & 0,0 & 0,0 & 0,0 \\
\hline & 120 & 0,0 & 0,0 & 0,0 & 0,0 & 0,0 \\
\hline \multirow[t]{5}{*}{1500} & 24 & 0,0 & 0,0 & 0,0 & 0,0 & 0,0 \\
\hline & 48 & 0,0 & 0,0 & 0,0 & 0,0 & 0,0 \\
\hline & 72 & 0,0 & 0,0 & 0,0 & 0,0 & 0,0 \\
\hline & 96 & 0,0 & 0,0 & 0,0 & 0,0 & 0,0 \\
\hline & 120 & 0,0 & 0,0 & 0,0 & 0,0 & 0,0 \\
\hline$P Z Q^{d}$ & 24 & 100,0 & 100,0 & 100,0 & 100,0 & 100,0 \\
\hline
\end{tabular}


Tabela 36 - Viabilidade de esquistossômulos de Schistosoma mansoni, com diferentes idades, em presença do extrato de Piper tuberculatum

\begin{tabular}{|c|c|c|c|c|c|c|}
\hline \multirow{3}{*}{$\begin{array}{l}\text { Extrato } \\
(\mu \mathrm{g} / \mathrm{ml})^{b}\end{array}$} & \multirow{3}{*}{$\begin{array}{c}\text { Tempo de } \\
\text { incubação } \\
\text { (h) }\end{array}$} & \multicolumn{5}{|c|}{ Mortalidade (\%) } \\
\hline & & \multicolumn{5}{|c|}{ Idade dos esquistossômulos (dias) } \\
\hline & & $\mathbf{R T}^{\mathbf{c}}$ & 1 & 3 & 5 & 7 \\
\hline \multirow[t]{5}{*}{$\mathbf{0}$} & 24 & 0,0 & 0,0 & 0,0 & 0,0 & 0,0 \\
\hline & 48 & 0,0 & 0,0 & 0,0 & 0,0 & 0,0 \\
\hline & 72 & 0,0 & 0,0 & 0,0 & 0,0 & 0,0 \\
\hline & 96 & 0,0 & 0,0 & 0,0 & 0,0 & 0,0 \\
\hline & 120 & 0,0 & 0,0 & 0,0 & 0,0 & 0,0 \\
\hline \multirow[t]{5}{*}{10} & 24 & 0,0 & 0,0 & 0,0 & 0,0 & 0,0 \\
\hline & 48 & 0,0 & 0,0 & 0,0 & 0,0 & 100 \\
\hline & 72 & 0,0 & 0,0 & 0,0 & 100,0 & 100,0 \\
\hline & 96 & 0,0 & 0,0 & 100,0 & 100,0 & 100,0 \\
\hline & 120 & 0,0 & 0,0 & 100,0 & 100,0 & 100,0 \\
\hline \multirow[t]{5}{*}{15} & 24 & 0,0 & 0,0 & 0,0 & 0,0 & 0,0 \\
\hline & 48 & 0,0 & 0,0 & 0,0 & 100,0 & 100,0 \\
\hline & 72 & 0,0 & 0,0 & 0,0 & 100,0 & 100,0 \\
\hline & 96 & 100,0 & 100,0 & 100,0 & 100,0 & 100,0 \\
\hline & 120 & 100,0 & 100,0 & 100,0 & 100,0 & 100,0 \\
\hline \multirow[t]{5}{*}{20} & 24 & 0,0 & 0,0 & 0,0 & 0,0 & 0,0 \\
\hline & 48 & 100,0 & 100,0 & 100,0 & 100,0 & 100,0 \\
\hline & 72 & 100,0 & 100,0 & 100,0 & 100,0 & 100,0 \\
\hline & 96 & 100,0 & 100,0 & 100,0 & 100,0 & 100,0 \\
\hline & 120 & 100,0 & 100,0 & 100,0 & 100,0 & 100,0 \\
\hline \multirow[t]{5}{*}{25} & 24 & 0,0 & 0,0 & 0,0 & 100,0 & 100,0 \\
\hline & 48 & 100,0 & 100,0 & 100,0 & 100,0 & 100,0 \\
\hline & 72 & 100,0 & 100,0 & 100,0 & 100,0 & 100,0 \\
\hline & 96 & 100,0 & 100,0 & 100,0 & 100,0 & 100,0 \\
\hline & 120 & 100,0 & 100,0 & 100,0 & 100,0 & 100,0 \\
\hline \multirow[t]{5}{*}{30} & 24 & 100,0 & 100,0 & 100,0 & 100,0 & 100,0 \\
\hline & 48 & 100,0 & 100,0 & 100,0 & 100,0 & 100,0 \\
\hline & 72 & 100,0 & 100,0 & 100,0 & 100,0 & 100,0 \\
\hline & 96 & 100,0 & 100,0 & 100,0 & 100,0 & 100,0 \\
\hline & 120 & 100,0 & 100,0 & 100,0 & 100,0 & 100,0 \\
\hline $\mathbf{P Z Q}^{\mathrm{d}}$ & 24 & 100,0 & 100,0 & 100,0 & 100,0 & 100,0 \\
\hline
\end{tabular}

a Porcentagem em relação a 450 esquistossômulos.

${ }^{\text {b }}$ Em DMSO 0,2\% no meio 169.

c RT: Esquistossômulo recém-transformado.

${ }^{d}$ Controle positivo: Praziquantel (PZQ $200 \mu \mathrm{g} / \mathrm{ml}$ ).

Os valores correspondem a três experimentos feitos em triplicatas. 
Tabela 37 - Viabilidade de esquistossômulos de Schistosoma mansoni, com diferentes idades, em presença do extrato de Piper crassinervium

\begin{tabular}{|c|c|c|c|c|c|c|}
\hline \multirow{3}{*}{$\begin{array}{l}\text { Extrato } \\
(\mu \mathrm{g} / \mathrm{ml})^{\mathrm{b}}\end{array}$} & \multirow{3}{*}{$\begin{array}{c}\text { Tempo de } \\
\text { incubação } \\
\text { (h) }\end{array}$} & \multicolumn{5}{|c|}{ Mortalidade $(\%)^{\mathrm{a}}$} \\
\hline & & \multicolumn{5}{|c|}{ Idade dos esquistossômulos (dias) } \\
\hline & & $\mathbf{R T}^{\mathbf{c}}$ & 1 & 3 & 5 & 7 \\
\hline \multirow[t]{5}{*}{0} & 24 & 0,0 & 0,0 & 0,0 & 0,0 & 0,0 \\
\hline & 48 & 0,0 & 0,0 & 0,0 & 0,0 & 0,0 \\
\hline & 72 & 0,0 & 0,0 & 0,0 & 0,0 & 0,0 \\
\hline & 96 & 0,0 & 0,0 & 0,0 & 0,0 & 0,0 \\
\hline & 120 & 0,0 & 0,0 & 0,0 & 0,0 & 0,0 \\
\hline \multirow[t]{5}{*}{10} & 24 & 0,0 & 0,0 & 0,0 & 0,0 & 0,0 \\
\hline & 48 & 100,0 & 100,0 & 0,0 & 0,0 & 0,0 \\
\hline & 72 & 100,0 & 100,0 & 100,0 & 0,0 & 0,0 \\
\hline & 96 & 100,0 & 100,0 & 100,0 & 100,0 & 0,0 \\
\hline & 120 & 100,0 & 100,0 & 100,0 & 100,0 & 0,0 \\
\hline \multirow[t]{5}{*}{20} & 24 & 0,0 & 0,0 & 0,0 & 0,0 & 0,0 \\
\hline & 48 & 100,0 & 100,0 & 100,0 & 0,0 & 0,0 \\
\hline & 72 & 100,0 & 100,0 & 100,0 & 100,0 & 0,0 \\
\hline & 96 & 100,0 & 100,0 & 100,0 & 100,0 & 0,0 \\
\hline & 120 & 100,0 & 100,0 & 100,0 & 100,0 & 100,0 \\
\hline \multirow[t]{5}{*}{100} & 24 & 0,0 & 0,0 & 0,0 & 0,0 & 0,0 \\
\hline & 48 & 100,0 & 100,0 & 100,0 & 100,0 & 0,0 \\
\hline & 72 & 100,0 & 100,0 & 100,0 & 100,0 & 0,0 \\
\hline & 96 & 100,0 & 100,0 & 100,0 & 100,0 & 100,0 \\
\hline & 120 & 100,0 & 100,0 & 100,0 & 100,0 & 100,0 \\
\hline \multirow[t]{5}{*}{150} & 24 & 100,0 & 100,0 & 6,2 & 0,0 & 0,0 \\
\hline & 48 & 100,0 & 100,0 & 100,0 & 100,0 & 100,0 \\
\hline & 72 & 100,0 & 100,0 & 100,0 & 100,0 & 100,0 \\
\hline & 96 & 100,0 & 100,0 & 100,0 & 100,0 & 100,0 \\
\hline & 120 & 100,0 & 100,0 & 100,0 & 100,0 & 100,0 \\
\hline \multirow[t]{5}{*}{200} & 24 & 100,0 & 100,0 & 100,0 & 100,0 & 0,0 \\
\hline & 48 & 100,0 & 100,0 & 100,0 & 100,0 & 100,0 \\
\hline & 72 & 100,0 & 100,0 & 100,0 & 100,0 & 100,0 \\
\hline & 96 & 100,0 & 100,0 & 100,0 & 100,0 & 100,0 \\
\hline & 120 & 100,0 & 100,0 & 100,0 & 100,0 & 100,0 \\
\hline $\mathbf{P Z Q}^{\mathbf{d}}$ & 24 & 100,0 & 100,0 & 100,0 & 100,0 & 100,0 \\
\hline
\end{tabular}

a Porcentagem em relação a 450 esquistossômulos.

${ }^{\mathrm{b}}$ Em DMSO 0,2\% no meio 169.

c RT: Esquistossômulo recém-transformado.

d Controle positivo: Praziquantel (PZQ $200 \mu \mathrm{g} / \mathrm{ml}$ ).

Os valores correspondem a três experimentos feitos em triplicatas. 
Tabela 38 - Viabilidade de esquistossômulos de Schistosoma mansoni, com diferentes idades, em presença do extrato de Piper diospyrifolium

\begin{tabular}{|c|c|c|c|c|c|c|}
\hline \multirow{3}{*}{$\begin{array}{l}\text { Extrato } \\
(\mu \mathrm{g} / \mathrm{ml})^{\mathrm{b}}\end{array}$} & \multirow{3}{*}{$\begin{array}{c}\text { Tempo de } \\
\text { incubação } \\
\text { (h) }\end{array}$} & \multicolumn{5}{|c|}{ Mortalidade $(\%)^{\mathrm{a}}$} \\
\hline & & \multicolumn{5}{|c|}{ Idade dos esquistossômulos (dias) } \\
\hline & & $\mathbf{R T}^{\mathbf{c}}$ & 1 & 3 & 5 & 7 \\
\hline \multirow[t]{5}{*}{$\mathbf{0}$} & 24 & 0,0 & 0,0 & 0,0 & 0,0 & 0,0 \\
\hline & 48 & 0,0 & 0,0 & 0,0 & 0,0 & 0,0 \\
\hline & 72 & 0,0 & 0,0 & 0,0 & 0,0 & 0,0 \\
\hline & 96 & 0,0 & 0,0 & 0,0 & 0,0 & 0,0 \\
\hline & 120 & 0,0 & 0,0 & 0,0 & 0,0 & 0,0 \\
\hline \multirow[t]{5}{*}{10} & 24 & 0,0 & 0,0 & 0,0 & 0,0 & 0,0 \\
\hline & 48 & 0,0 & 0,0 & 0,0 & 0,0 & 0,0 \\
\hline & 72 & 0,0 & 0,0 & 100,0 & 100,0 & 100,0 \\
\hline & 96 & 100,0 & 100,0 & 100,0 & 100,0 & 100,0 \\
\hline & 120 & 100,0 & 100,0 & 100,0 & 100,0 & 100,0 \\
\hline \multirow[t]{5}{*}{20} & 24 & 0,0 & 0,0 & 0,0 & 0,0 & 100,0 \\
\hline & 48 & 100,0 & 100,0 & 100,0 & 100,0 & 100,0 \\
\hline & 72 & 100,0 & 100,0 & 100,0 & 100,0 & 100,0 \\
\hline & 96 & 100,0 & 100,0 & 100,0 & 100,0 & 100,0 \\
\hline & 120 & 100,0 & 100,0 & 100,0 & 100,0 & 100,0 \\
\hline \multirow[t]{5}{*}{50} & 24 & 0,0 & 0,0 & 100,0 & 100,0 & 100,0 \\
\hline & 48 & 100,0 & 100,0 & 100,0 & 100,0 & 100,0 \\
\hline & 72 & 100,0 & 100,0 & 100,0 & 100,0 & 100,0 \\
\hline & 96 & 100,0 & 100,0 & 100,0 & 100,0 & 100,0 \\
\hline & 120 & 100,0 & 100,0 & 100,0 & 100,0 & 100,0 \\
\hline \multirow[t]{5}{*}{100} & 24 & 0,0 & 100,0 & 100,0 & 100,0 & 100,0 \\
\hline & 48 & 100,0 & 100,0 & 100,0 & 100,0 & 100,0 \\
\hline & 72 & 100,0 & 100,0 & 100,0 & 100,0 & 100,0 \\
\hline & 96 & 100,0 & 100,0 & 100,0 & 100,0 & 100,0 \\
\hline & 120 & 100,0 & 100,0 & 100,0 & 100,0 & 100,0 \\
\hline \multirow[t]{5}{*}{150} & 24 & 100,0 & 100,0 & 100,0 & 100,0 & 100,0 \\
\hline & 48 & 100,0 & 100,0 & 100,0 & 100,0 & 100,0 \\
\hline & 72 & 100,0 & 100,0 & 100,0 & 100,0 & 100,0 \\
\hline & 96 & 100,0 & 100,0 & 100,0 & 100,0 & 100,0 \\
\hline & 120 & 100,0 & 100,0 & 100,0 & 100,0 & 100,0 \\
\hline $\mathbf{P Z Q}^{\mathbf{d}}$ & 24 & 100,0 & 100,0 & 100,0 & 100,0 & 100,0 \\
\hline
\end{tabular}

a Porcentagem em relação a 450 esquistossômulos.

${ }^{\mathrm{b}}$ Em DMSO 0,2\% no meio 169.

c RT: Esquistossômulo recém-transformado.

d Controle positivo: Praziquantel (PZQ $200 \mu \mathrm{g} / \mathrm{ml}$ ).

Os valores correspondem a três experimentos feitos em triplicatas. 
Tabela 39 - Viabilidade de esquistossômulos de Schistosoma mansoni, com diferentes idades, em presença do extrato de Piper fuligineum

\begin{tabular}{|c|c|c|c|c|c|c|}
\hline \multirow{3}{*}{$\begin{array}{l}\text { Extrato } \\
(\mu \mathrm{g} / \mathrm{ml})^{\mathrm{b}}\end{array}$} & \multirow{3}{*}{$\begin{array}{c}\text { Tempo de } \\
\text { incubação } \\
\text { (h) }\end{array}$} & \multicolumn{5}{|c|}{ Mortalidade $(\%)^{a}$} \\
\hline & & \multicolumn{5}{|c|}{ Idade dos esquistossômulos (dias) } \\
\hline & & $\mathbf{R T}^{\mathbf{c}}$ & 1 & 3 & 5 & 7 \\
\hline \multirow[t]{5}{*}{$\mathbf{0}$} & 24 & 0,0 & 0,0 & 0,0 & 0,0 & 0,0 \\
\hline & 48 & 0,0 & 0,0 & 0,0 & 0,0 & 0,0 \\
\hline & 72 & 0,0 & 0,0 & 0,0 & 0,0 & 0,0 \\
\hline & 96 & 0,0 & 0,0 & 0,0 & 0,0 & 0,0 \\
\hline & 120 & 0,0 & 0,0 & 0,0 & 0,0 & 0,0 \\
\hline \multirow[t]{5}{*}{10} & 24 & 0,0 & 0,0 & 0,0 & 0,0 & 0,0 \\
\hline & 48 & 100,0 & 100,0 & 100,0 & 0,0 & 0,0 \\
\hline & 72 & 100,0 & 100,0 & 100,0 & 100,0 & 0,0 \\
\hline & 96 & 100,0 & 100,0 & 100,0 & 100,0 & 0,0 \\
\hline & 120 & 100,0 & 100,0 & 100,0 & 100,0 & 0,0 \\
\hline \multirow[t]{5}{*}{20} & 24 & 100,0 & 100,0 & 100,0 & 0,0 & 0,0 \\
\hline & 48 & 100,0 & 100,0 & 100,0 & 100,0 & 0,0 \\
\hline & 72 & 100,0 & 100,0 & 100,0 & 100,0 & 100,0 \\
\hline & 96 & 100,0 & 100,0 & 100,0 & 100,0 & 100,0 \\
\hline & 120 & 100,0 & 100,0 & 100,0 & 100,0 & 100,0 \\
\hline \multirow[t]{5}{*}{30} & 24 & 100,0 & 100,0 & 100,0 & 0,0 & 0,0 \\
\hline & 48 & 100,0 & 100,0 & 100,0 & 100,0 & 100,0 \\
\hline & 72 & 100,0 & 100,0 & 100,0 & 100,0 & 100,0 \\
\hline & 96 & 100,0 & 100,0 & 100,0 & 100,0 & 100,0 \\
\hline & 120 & 100,0 & 100,0 & 100,0 & 100,0 & 100,0 \\
\hline \multirow[t]{5}{*}{40} & 24 & 100,0 & 100,0 & 100,0 & 100,0 & 0,0 \\
\hline & 48 & 100,0 & 100,0 & 100,0 & 100,0 & 100,0 \\
\hline & 72 & 100,0 & 100,0 & 100,0 & 100,0 & 100,0 \\
\hline & 96 & 100,0 & 100,0 & 100,0 & 100,0 & 100,0 \\
\hline & 120 & 100,0 & 100,0 & 100,0 & 100,0 & 100,0 \\
\hline \multirow[t]{5}{*}{50} & 24 & 100,0 & 100,0 & 100,0 & 100,0 & 100,0 \\
\hline & 48 & 100,0 & 100,0 & 100,0 & 100,0 & 100,0 \\
\hline & 72 & 100,0 & 100,0 & 100,0 & 100,0 & 100,0 \\
\hline & 96 & 100,0 & 100,0 & 100,0 & 100,0 & 100,0 \\
\hline & 120 & 100,0 & 100,0 & 100,0 & 100,0 & 100,0 \\
\hline $\mathbf{P Z Q}^{\mathbf{d}}$ & 24 & 100,0 & 100,0 & 100,0 & 100,0 & 100,0 \\
\hline
\end{tabular}

a Porcentagem em relação a 450 esquistossômulos.

b Em DMSO 0,2\% no meio 169.

c RT: Esquistossômulo recém-transformado.

${ }^{d}$ Controle positivo: Praziquantel (PZQ $200 \mu \mathrm{g} / \mathrm{ml}$ ).

Os valores correspondem a três experimentos feitos em triplicatas. 
Tabela 40 - Viabilidade de esquistossômulos de Schistosoma mansoni, com diferentes idades, em presença do extrato de Piper gaudichaudianum

\begin{tabular}{|c|c|c|c|c|c|c|}
\hline \multirow{3}{*}{$\begin{array}{l}\text { Extrato } \\
(\mu \mathrm{g} / \mathrm{ml})^{\mathrm{b}}\end{array}$} & \multirow{3}{*}{$\begin{array}{c}\text { Tempo de } \\
\text { incubação } \\
\text { (h) }\end{array}$} & \multicolumn{5}{|c|}{ Mortalidade $(\%)^{\mathrm{a}}$} \\
\hline & & \multicolumn{5}{|c|}{ Idade dos esquistossômulos (dias) } \\
\hline & & $\mathbf{R T}^{\mathbf{c}}$ & 1 & 3 & 5 & 7 \\
\hline \multirow[t]{5}{*}{$\mathbf{0}$} & 24 & 0,0 & 0,0 & 0,0 & 0,0 & 0,0 \\
\hline & 48 & 0,0 & 0,0 & 0,0 & 0,0 & 0,0 \\
\hline & 72 & 0,0 & 0,0 & 0,0 & 0,0 & 0,0 \\
\hline & 96 & 0,0 & 0,0 & 0,0 & 0,0 & 0,0 \\
\hline & 120 & 0,0 & 0,0 & 0,0 & 0,0 & 0,0 \\
\hline \multirow[t]{5}{*}{20} & 24 & 0,0 & 0,0 & 0,0 & 0,0 & 0,0 \\
\hline & 48 & 0,0 & 0,0 & 0,0 & 0,0 & 0,0 \\
\hline & 72 & 0,0 & 0,0 & 0,0 & 0,0 & 0,0 \\
\hline & 96 & 0,0 & 0,0 & 0,0 & 0,0 & 0,0 \\
\hline & 120 & 100,0 & 100,0 & 0,0 & 0,0 & 0,0 \\
\hline \multirow[t]{5}{*}{50} & 24 & 0,0 & 0,0 & 0,0 & 0,0 & 0,0 \\
\hline & 48 & 0,0 & 0,0 & 0,0 & 0,0 & 0,0 \\
\hline & 72 & 0,0 & 0,0 & 0,0 & 0,0 & 0,0 \\
\hline & 96 & 100,0 & 100,0 & 0,0 & 0,0 & 0,0 \\
\hline & 120 & 100,0 & 100,0 & 100,0 & 100,0 & 0,0 \\
\hline \multirow[t]{5}{*}{75} & 24 & 0,0 & 0,0 & 0,0 & 0,0 & 0,0 \\
\hline & 48 & 100,0 & 100,0 & 8,8 & 0,0 & 0,0 \\
\hline & 72 & 100,0 & 100,0 & 100,0 & 100,0 & 100,0 \\
\hline & 96 & 100,0 & 100,0 & 100,0 & 100,0 & 100,0 \\
\hline & 120 & 100,0 & 100,0 & 100,0 & 100,0 & 100,0 \\
\hline \multirow[t]{5}{*}{100} & 24 & 100,0 & 100,0 & 100,0 & 0,0 & 0,0 \\
\hline & 48 & 100,0 & 100,0 & 100,0 & 100,0 & 100,0 \\
\hline & 72 & 100,0 & 100,0 & 100,0 & 100,0 & 100,0 \\
\hline & 96 & 100,0 & 100,0 & 100,0 & 100,0 & 100,0 \\
\hline & 120 & 100,0 & 100,0 & 100,0 & 100,0 & 100,0 \\
\hline \multirow[t]{5}{*}{150} & 24 & 100,0 & 100,0 & 100,0 & 100,0 & 100,0 \\
\hline & 48 & 100,0 & 100,0 & 100,0 & 100,0 & 100,0 \\
\hline & 72 & 100,0 & 100,0 & 100,0 & 100,0 & 100,0 \\
\hline & 96 & 100,0 & 100,0 & 100,0 & 100,0 & 100,0 \\
\hline & 120 & 100,0 & 100,0 & 100,0 & 100,0 & 100,0 \\
\hline $\mathbf{P Z Q}^{\mathbf{d}}$ & 24 & 100,0 & 100,0 & 100,0 & 100,0 & 100,0 \\
\hline
\end{tabular}

a Porcentagem em relação a 450 esquistossômulos.

${ }^{\mathrm{b}}$ Em DMSO 0,2\% no meio 169.

c RT: Esquistossômulo recém-transformado.

d Controle positivo: Praziquantel (PZQ $200 \mu \mathrm{g} / \mathrm{ml}$ ).

Os valores correspondem a três experimentos feitos em triplicatas. 
Tabela 41 - Viabilidade de esquistossômulos de Schistosoma mansoni, com diferentes idades, em presença do extrato de Pothomorphe umbellata

\begin{tabular}{|c|c|c|c|c|c|c|}
\hline \multirow{3}{*}{$\begin{array}{l}\text { Extrato } \\
(\mu \mathrm{g} / \mathrm{ml})^{\mathrm{b}}\end{array}$} & \multirow{3}{*}{$\begin{array}{c}\text { Tempo de } \\
\text { incubação } \\
\text { (h) }\end{array}$} & \multicolumn{5}{|c|}{ Mortalidade (\%) } \\
\hline & & \multicolumn{5}{|c|}{ Idade dos esquistossômulos (dias) } \\
\hline & & $\mathbf{R T}^{\mathbf{c}}$ & 1 & 3 & 5 & 7 \\
\hline \multirow[t]{5}{*}{$\mathbf{0}$} & 24 & 0,0 & 0,0 & 0,0 & 0,0 & 0,0 \\
\hline & 48 & 0,0 & 0,0 & 0,0 & 0,0 & 0,0 \\
\hline & 72 & 0,0 & 0,0 & 0,0 & 0,0 & 0,0 \\
\hline & 96 & 0,0 & 0,0 & 0,0 & 0,0 & 0,0 \\
\hline & 120 & 0,0 & 0,0 & 0,0 & 0,0 & 0,0 \\
\hline \multirow[t]{5}{*}{10} & 24 & 0,0 & 0,0 & 0,0 & 0,0 & 100,0 \\
\hline & 48 & 0,0 & 0,0 & 0,0 & 100,0 & 100,0 \\
\hline & 72 & 0,0 & 0,0 & 0,0 & 100,0 & 100,0 \\
\hline & 96 & 0,0 & 0,0 & 100,0 & 100,0 & 100,0 \\
\hline & 120 & 0,0 & 100,0 & 100,0 & 100,0 & 100,0 \\
\hline \multirow[t]{5}{*}{20} & 24 & 0,0 & 0,0 & 0,0 & 100,0 & 100,0 \\
\hline & 48 & 100,0 & 100,0 & 100,0 & 100,0 & 100,0 \\
\hline & 72 & 100,0 & 100,0 & 100,0 & 100,0 & 100,0 \\
\hline & 96 & 100,0 & 100,0 & 100,0 & 100,0 & 100,0 \\
\hline & 120 & 100,0 & 100,0 & 100,0 & 100,0 & 100,0 \\
\hline \multirow[t]{5}{*}{40} & 24 & 0,0 & 0,0 & 0,0 & 100,0 & 100,0 \\
\hline & 48 & 100,0 & 100,0 & 100,0 & 100,0 & 100,0 \\
\hline & 72 & 100,0 & 100,0 & 100,0 & 100,0 & 100,0 \\
\hline & 96 & 100,0 & 100,0 & 100,0 & 100,0 & 100,0 \\
\hline & 120 & 100,0 & 100,0 & 100,0 & 100,0 & 100,0 \\
\hline \multirow[t]{5}{*}{50} & 24 & 0,0 & 0,0 & 0,0 & 100,0 & 100,0 \\
\hline & 48 & 100,0 & 100,0 & 100,0 & 100,0 & 100,0 \\
\hline & 72 & 100,0 & 100,0 & 100,0 & 100,0 & 100,0 \\
\hline & 96 & 100,0 & 100,0 & 100,0 & 100,0 & 100,0 \\
\hline & 120 & 100,0 & 100,0 & 100,0 & 100,0 & 100,0 \\
\hline \multirow[t]{5}{*}{100} & 24 & 100,0 & 100,0 & 100,0 & 100,0 & 100,0 \\
\hline & 48 & 100,0 & 100,0 & 100,0 & 100,0 & 100,0 \\
\hline & 72 & 100,0 & 100,0 & 100,0 & 100,0 & 100,0 \\
\hline & 96 & 100,0 & 100,0 & 100,0 & 100,0 & 100,0 \\
\hline & 120 & 100,0 & 100,0 & 100,0 & 100,0 & 100,0 \\
\hline $\mathbf{P Z Q}^{\mathbf{d}}$ & 24 & 100,0 & 100,0 & 100,0 & 100,0 & 100,0 \\
\hline
\end{tabular}

a Porcentagem em relação a 450 esquistossômulos.

${ }^{\text {b }}$ Em DMSO 0,2\% no meio 169.

c RT: Esquistossômulo recém-transformado.

${ }^{d}$ Controle positivo: Praziquantel (PZQ $200 \mu \mathrm{g} / \mathrm{ml}$ ).

Os valores correspondem a três experimentos feitos em triplicatas. 
Diferenças na atividade de compostos em esquistossômulos de diferentes idades foram assinaladas na literatura. Xiao, Mei e Jiao (2009) avaliaram, in vitro, o efeito da mefloquina, um aminoálcool antimalárico, em Schistosoma japonicum. No caso, os autores verificaram que os esquistossômulos com 3 horas foram mais susceptíveis que parasitas com 7 dias, apresentando efeito letal com mefloquina $5 \mu \mathrm{g} / \mathrm{ml}$ e $10 \mu \mathrm{g} / \mathrm{ml}$, respectivamente. Nos experimentos realizados neste trabalho empregando esquistossômulos de $S$. mansoni (recém-transformado, 1, 3, 5 e 7 dias de idade), os helmintos mais novos são mais susceptíveis quando expostos aos extratos de Piper crassinervium, $P$. fuligineum e $P$. gaudichaudianum; enquanto que os esquistossômulos mais velhos são mais susceptíveis aos compostos piplartina, dermaseptina, epiisopiloturina e grandisina, assim como os extratos de Piper tuberculatum, Piper diospyrifolium e Pothomorphe umbellata.

Com relação aos esquistossômulos com diferentes idades, devem-se ressaltar alguns aspectos biológicos nos primeiros dias de idade. O esquistossômulo é a forma capaz de migrar pelos tecidos e vasos do hospedeiro mamífero, tendo capacidade imunogênica e sendo, também, um alvo de defesas específicas do hospedeiro (WILSON et al., 1978, 1990; MILLER e WILSON, 1978; WILSON e COULSON, 1986; WILSON; COULSON; DIXON, 1986; CAPRON, 1992; PEARCE e SHER, 1987; GOBERT; CHAI; MCMANUS, 2007). Até atingirem a maturidade sexual (após 35 dias), os esquistossomos passam por diversas mudanças fisiológicas e morfológicas. Em S. mansoni, entre uma e três horas após a penetração das cercárias na pele do hospedeiro, um aumento na temperatura e na osmolaridade inicia uma série de adaptações, que rapidamente preparam os parasitas para sobreviverem ao novo ambiente. Em apenas uma hora, a maior parte do glicocálix é perdida e o tegumento começa a se converter de uma estrutura trilaminada para uma estrutura heptalaminada (STIREWALT, 1974; SKELLY e ALAN WILSON, 2006; GOBERT; CHAI; MCMANUS, 2007). Com 3 horas, membrana externa já é heptalaminada e o tegumento contém grandes vacúolos e pequenos corpos membranosos. Nos esquistossômulos de 24 horas ocorre a formação de pregas e cavidades na superfície, além da regulação da proteína de choque térmico (HSP 70) (HOCKLEY, 1973; HOCKLEY e MCLAREN, 1973; STIREWALT, 1974, BLANTON e LICATE, 1992). A transformação torna o tubo digestivo funcional, com diversas vesículas ricas em fosfatase ácida. Além disso, diversas glicoproteínas são encontradas nessa fase parasitária, com mudanças na expressão de acordo com a idade do parasita (WILSON et al., 1978; AURIAULT et al., 1982; CARNEIRO-SANTOS et al., 2001). Após o segundo dia, as glândulas acetabulares e seus ductos desaparecem, o que caracteriza a real transformação de cercárias em esquistossômulo. A partir desse período se inicia o processo de alongamento dos esquistossômulos, e começa ocorrer regressão dos espinhos tegumentares na parte central do corpo, mantendo-se, contudo, nas 
extremidades anterior e posterior (CRABTREE e WILSON, 1980). Em torno de 72 horas, a região central do corpo torna-se quase totalmente despida de espinhos e o tegumento fica repleto de pequenas covas. Os espinhos não são mais visualizados em torno de 96 horas (CRABTREE e WILSON, 1980). Após o quarto dia, os esquistossômulos perdem a camada intersticial fibrosa subtegumentar e parte da musculatura anterior; o tegumento continua com pequenas covas e, dependendo do grau de extensão corporal, exibe pregas e sulcos. Após o quinto dia, o tegumento torna-se mais espesso e os parasitas chegam a ultrapassar, em até quatro vezes, o comprimento dos helmintos dos dois dias anteriores; o tubo digestivo também apresenta-se mais desenvolvido e a partir dessa fase ocorrem mudanças para formação desse tubo digestivo: ceco com pigmento e bifurcação (WILSON et al., 1978; CRABTREE e WILSON, 1980). Do ponto de vista bioquímico, inúmeras peptidases já foram descritas em diferentes fases de desenvolvimento do $S$. mansoni. Muitas dessas enzimas estão associadas ao tegumento do esquistossômulo e estariam envolvidas no mecanismo de proteção do parasita contra a resposta protetora do hospedeiro (AURIAULT et al., 1981, 1982; DAMONEVILLE et al., 1982). Além disso, a superfície dos esquistossômulos é dinâmica, com expressão de diferentes proteínas, muitas de forma alternada, nessa fase jovem de S. mansoni (PAYARES et al., 1985).

Dessa forma, considerando as mudanças morfológicas e fisiológicas nas diferentes fases dos esquistossômulos, associadas às características peculiares dos compostos e extratos vegetais, esperávamos, de fato, as diferenças na susceptibilidade entre os esquistossômulos (recém-tranformados e com 1, 3, 5 e 7 dias de idade) quando expostos aos produtos naturais (Tabelas 31-41).

Como já citado neste estudo, diversos trabalhos relatam produtos naturais em Schistosoma mansoni. Por outro lado, o efeito esquistossomicida desses produtos nas formas jovens (esquistossômulos) foi pouco assinalado na literatura. Na terapêutica experimental da esquistossomose, somente os derivados de artemisina, especialmente o arteméter e o artenusado, apresentam características profiláticas, atuando nos esquistossômulos (XIAO et al. 2002; UTZINGER et al., 2001a, 2001b). Entretanto, esses compostos são mais eficazes na forma adulto-jovem (21 dias de idade), e apresentam baixa atividade em esquistossômulos ( 5 e 7 dias de idade) e vermes adultos (SHUHUA et al., 2000; XIAO et al., 2002). Desta forma, para atingir diferentes formas do parasita a associação de arteméter e praziquantel vem sendo empregada em alguns estudos (XIAO et al. 2002; UTZINGER et al., 2001a, 2001b, 2003). Apesar de haver diminuição significativa da carga parasitária com esta associação, sendo, inclusive, maior do que a obtida com o praziquantel isoladamente (UTZINGER et al., 2003), o uso contínuo e prolongado dos derivados de artemisina traz preocupações em áreas endêmicas para 
malária, pois existe a possibilidade do aparecimento de resistência a essas drogas (UTZINGER et al., 2003; KATZ et al., 2008).

Nesse contexto, a busca por drogas com características, concomitante, curativas e profiláticas tem aumentado. Recentemente, Boissier et al. (2009) mostraram que as trioxaquinas, composto antimalárico sintetizado de artemisina, apresentam efeito in vitro em adultos (49 dias) e adultos-jovens (21 dias) de S. mansoni, nas concentrações de 50 $\mu \mathrm{g} / \mathrm{ml}$ e $5 \mu \mathrm{g} / \mathrm{ml}$, respectivamente; no entanto, os autores não avaliaram os efeitos desses compostos em parasitas mais novos, por exemplo, até 7 dias. Em estudos in vitro para avaliar a toxicidade de ácido aracdônico em S. mansoni, El Ridi et al. (2010) assinalaram efeito helminticida em esquistossômulos (7 dias) e vermes adultos (42 dias) nas concentrações, de ácido aracdônico, iguais ou superiores a $5.000 \mu \mathrm{M}$. Manneck, Haggenmüller e Keiser (2010) relataram, in vitro, que alguns isômeros de mefloquina são tóxicos para esquistossômulos de $S$. mansoni nas concentrações de $3 \mu \mathrm{g} / \mathrm{ml}$ a 10 $\mu \mathrm{g} / \mathrm{ml}$, enquanto que a ação letal para adultos foi com $10 \mu \mathrm{g} / \mathrm{ml}$.

No geral, no presente estudo, considerando a concentração dos 5 compostos e 6 extratos naturais ensaiados, a análise dos experimentos indicou que esquistossômulos de Schistosoma mansoni são mais susceptíveis aos compostos piplartina e dermaseptina, e ao extrato etanólicos obtido de folhas de Piper diospyrifolium. Além disso, comparativamente, o efeito esquistossomicida observado com os compostos ou extratos ocorreu em concentrações menores do que o controle positivo (praziquantel 150-200 $\mu \mathrm{g} / \mathrm{ml}$ ); sendo exceções: epiisopiloturina e piperina. As concentrações mínimas dos compostos e extratos capazes de matar $100 \%$ dos parasitas, independentemente do tempo de incubação, estão listadas na Tabela 42. 


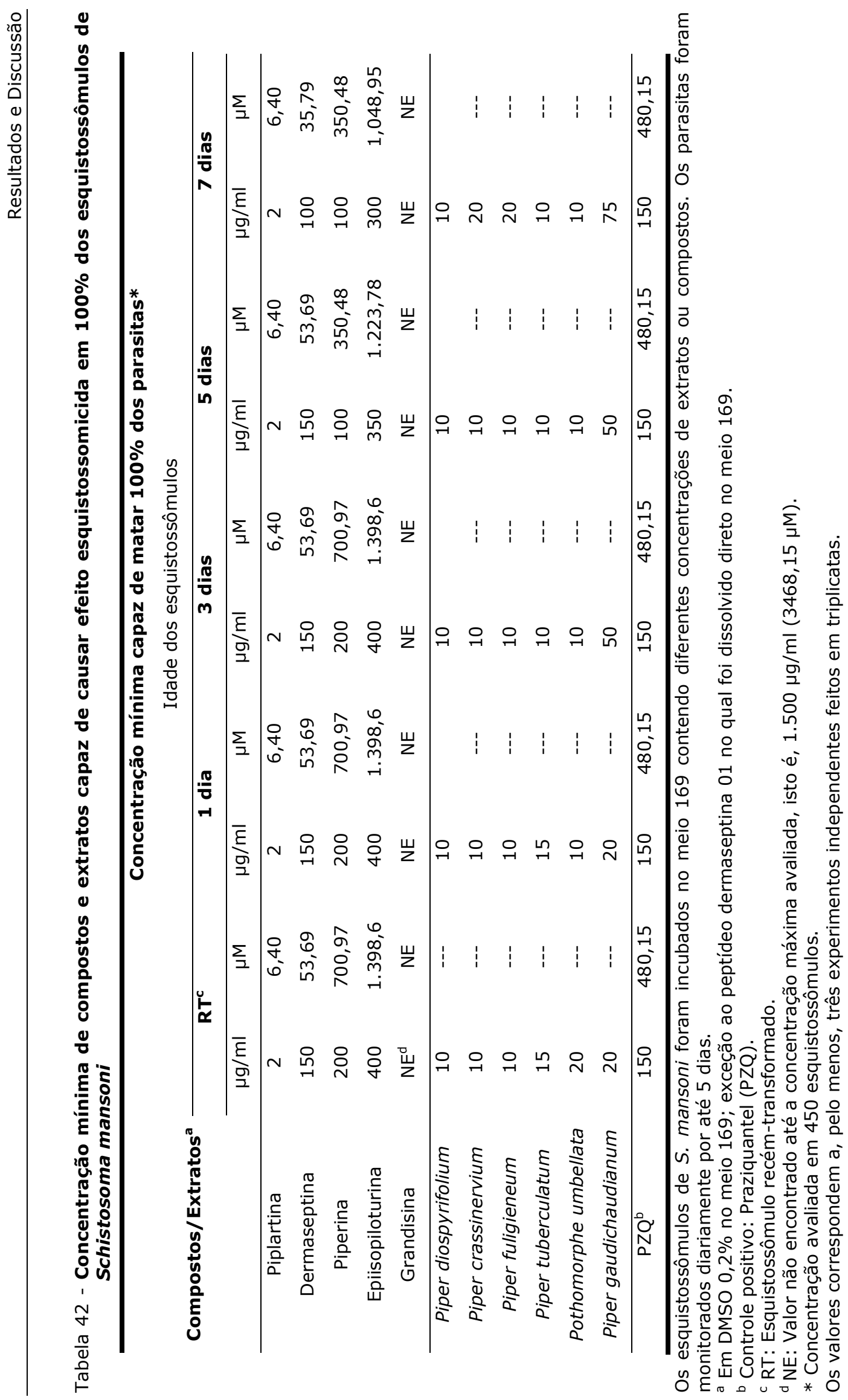


A transformação das cercárias em esquistossômulos pode ser conseguida in vitro por alguns métodos mecânicos, já assinalados em trabalhos da década de 1970. Os mais comumente empregados são: a) agitação da suspensão de cercárias em um agitador de tubos, tipo vortex (RAMALHO-PINTO et al., 1974); b) a passagem da cercária, sob pressão, através de uma agulha de pequeno calibre (COLLEY e WIKEL, 1974). Neste estudo foi utilizado a metodologia descrita por Ramalho-Pinto et al. (1974), tendo em vista que essa é a mais recomendada, muito provavelmente devido à sua simplicidade (RAMIREZ et al., 2007; KEISER et al., 2010). Além disso, segundo Alan Wilson, 2010 (comunicação pessoal; University of York, York, United Kingdom), a transformação mecânica em agitador seria menos estressante do que a passagem dos parasitas, sob pressão, através de uma agulha por repetidas vezes.

Outro aspecto relevante para os ensaios biológicos com as formas jovens de esquistossomos antes do cultivo in vitro, as cercárias mecanicamente transformadas em esquistossômulos foram incubadas por 3 horas a $37^{\circ} \mathrm{C}$, em atmosfera de $\mathrm{CO}_{2}$ a $5 \%$. Dessa forma, os parasitas recém-transformados têm 3 horas de idade (CURWEN et al., 2006). Esse período de incubação previamente aos ensaios para avaliar a atividade de compostos e extratos vegetais em esquistossômulos é importante para a adaptação à vida parasitária, que consiste no esvaziamento das glândulas acetabulares e remoção do glicocálix, além de aumentar a área da superfície da membrana plasmática, possibilitando maior absorção ou secreção de material (GAZZINELLI et al., 1973, 1974; HOCKLEY e MACLAREN, 1973; HOWELLS et al., 1974, 1975; RAMALHO-PINTO et al., 1974; STIREWALT, 1974; MCKERROW, 1989; MCKERROW e SALTER, 2002; SKELLY e ALAN WILSON, 2006).

In vivo, os parasitas apresentam características biológicas diferentes dos helmintos mantidos in vitro. Entretanto, neste estudo, a idade dos esquistossômulos foi contada in vitro devido à dificuldade de se retirar essa forma parasitária do hospedeiro. Além disso, obter quantidades suficientes de esquistossômulos diretamente do tecido da pele e do pulmão para fins de investigação é demorado, tem baixo rendimento e envolve o trabalho com muitos mamíferos (GOBERT et al., 2010). Dessa forma, muitos pesquisadores utilizam cercárias mecanicamente transformadas e mantêm os parasitas em meio de cultura. Essa estratégia in vitro também confere uniformidade na maturação do parasita, o que não pode ser alcançado in vivo devido à variação no tempo necessário de permanência no tecido e migração pelos vasos sanguíneos (GOBERT et al., 2010). Além disso, esquistossômulos com diferentes idades in vitro são amplamente usados nos ensaios biológicos, preservando sua capacidade de maturação após introdução no hospedeiro, sendo equivalente morfológica e fisiologicamente a idade in vivo (BASCH, 1981a, 1981b; BASCH e HUMBERT, 1981; HARROP e WILSON, 1993; BRITO et al., 2002; DILON et al., 2006). 
Estudos em Schistosoma mansoni, com diferentes idades (5, 7, 14, 21, 28, 35 e 42 dias), expostos ao arteméter apresentaram resultados interessantes: a mortalidade é baixa nos parasitas com 5 e 7 dias de idade, com um aumento gradual na idade de 14 dias, e atinge alta mortalidade nos parasitas com 21 e 28 dias; nas idades subsequentes (35 e 42 dias) houve redução da taxa de mortalidade (SHUHUA et al., 2000b; XIAO et al., 2002). Apesar de ser comumente empregado em alguns países asiáticos, o mecanismo pelo qual o arteméter apresenta alta eficácia somente nos parasitas com 3 a 4 semanas ainda é desconhecido (XIAO et al., 2002; UTZINGER et al., 2001a, 2001b).

Em nosso estudo, os resultados de experimentos com vermes adultos e esquistossômulos permitiram constatar que os compostos e extratos apresentaram atividade biológica diretamente dependente da concentração e do tempo de incubação. Comparativamente, no geral, a concentração mínima capaz de matar $100 \%$ dos parasitas difere entre esquistossômulos e adultos. Por exemplo, a mortalidade de todos os helmintos recém transformados ( 3 horas), com 7 dias de idade e adultos (machos e fêmeas, com 49 dias) em presença do peptídeo dermaseptina foi obtida com as concentrações de $150 \mu \mathrm{g} / \mathrm{ml}, 100 \mu \mathrm{g} / \mathrm{ml}$ e $50 \mu \mathrm{g} / \mathrm{ml}$, respectivamente. Por outro lado, 10 $\mu \mathrm{g} / \mathrm{ml}$ do extrato de Piper diospyrifolium foram suficientes para causar efeito antihelmintos em todos os esquistossômulos, e somente quando a concentração é aumentada para $50 \mu \mathrm{g} / \mathrm{ml}$, a mortalidade de $100 \%$ em parasitas adultos é atingida. A Tabela 43 apresenta um resumo das concentrações de compostos e extratos que causam a mortalidade de $100 \%$ dos parasitas recém transformados, 7 dias e 49 dias de idade. 


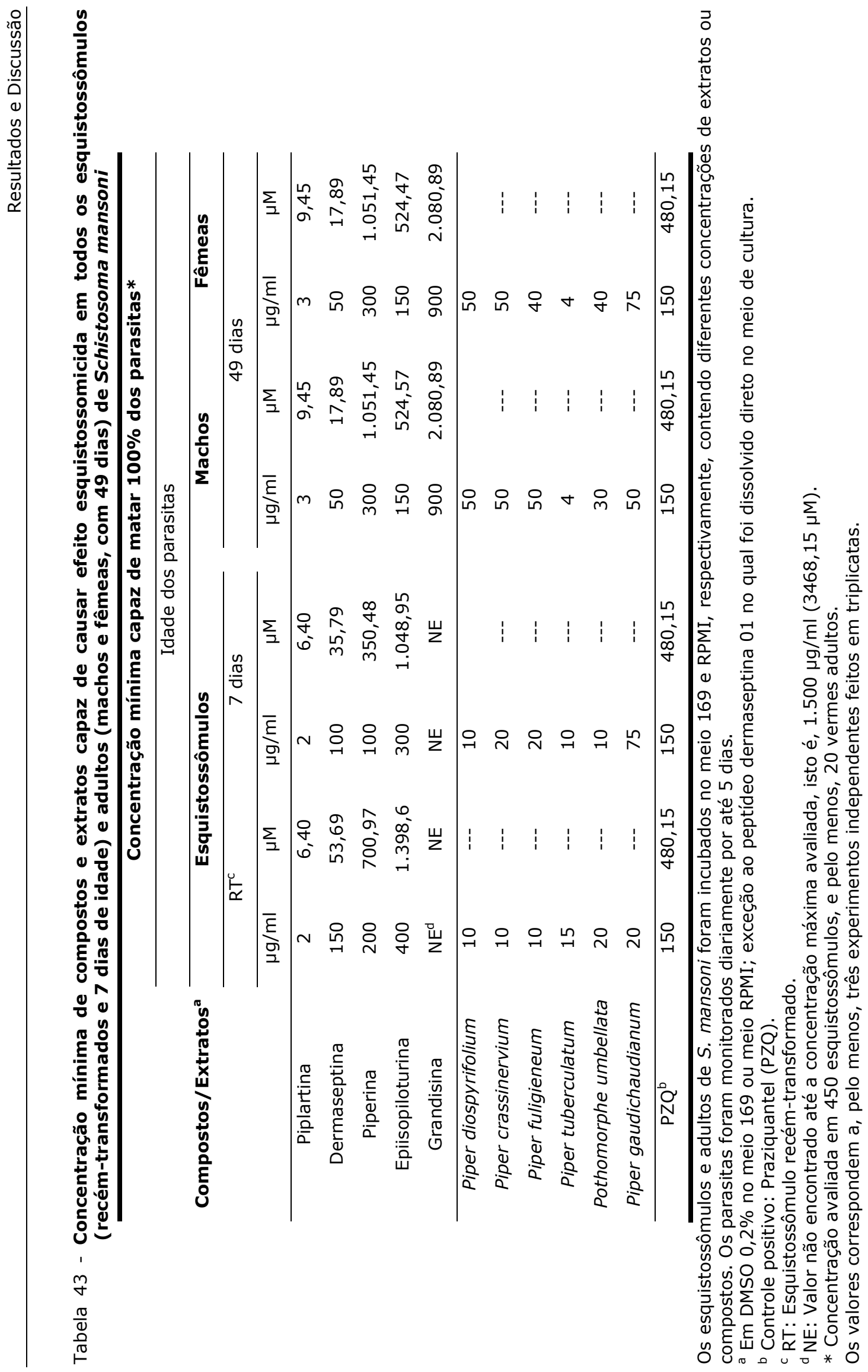




\subsubsection{Alterações no tegumento de esquistossômulos, com diferentes idades, em presença de compostos e extratos}

Além do efeito letal em esquistossômulos de $S$. mansoni, durante o monitoramento microscópico das culturas foi possível também notar que os compostos e extratos causaram a contração nos esquistossômulos, independentemente da idade, previamente ao efeito antiparasitário. Esse encurtamento dos helmintos foi dependente da concentração e mais notadamente com os compostos piplartina e piperina, e com todos os extratos. Por outro lado, o praziquantel, usado aqui como controle positivo na concentração de 150 mg/ml, não causou a contração dos esquistossômulos antes da ação letal.

Não obstante a contração muscular observada com microscopia de luz, em técnica de campo claro, uma análise mais detalhada foi realizada nos esquistossômulos expostos aos compostos e extratos. Nos experimentos, após o término do período de incubação (120 horas) ou ocorrência de morte, os parasitas foram fixados em solução AFA e analisados por microscopia confocal. Comparativamente aos controles contendo somente meio de cultura ou praziquantel, nas concentrações letais notou-se alterações morfológicas em todos os parasitas. Os danos no tegumento foram dependentes da idade dos esquistossômulos e da concentração dos compostos e extratos ensaiados (Figuras 34-37 e dados não mostrados). 

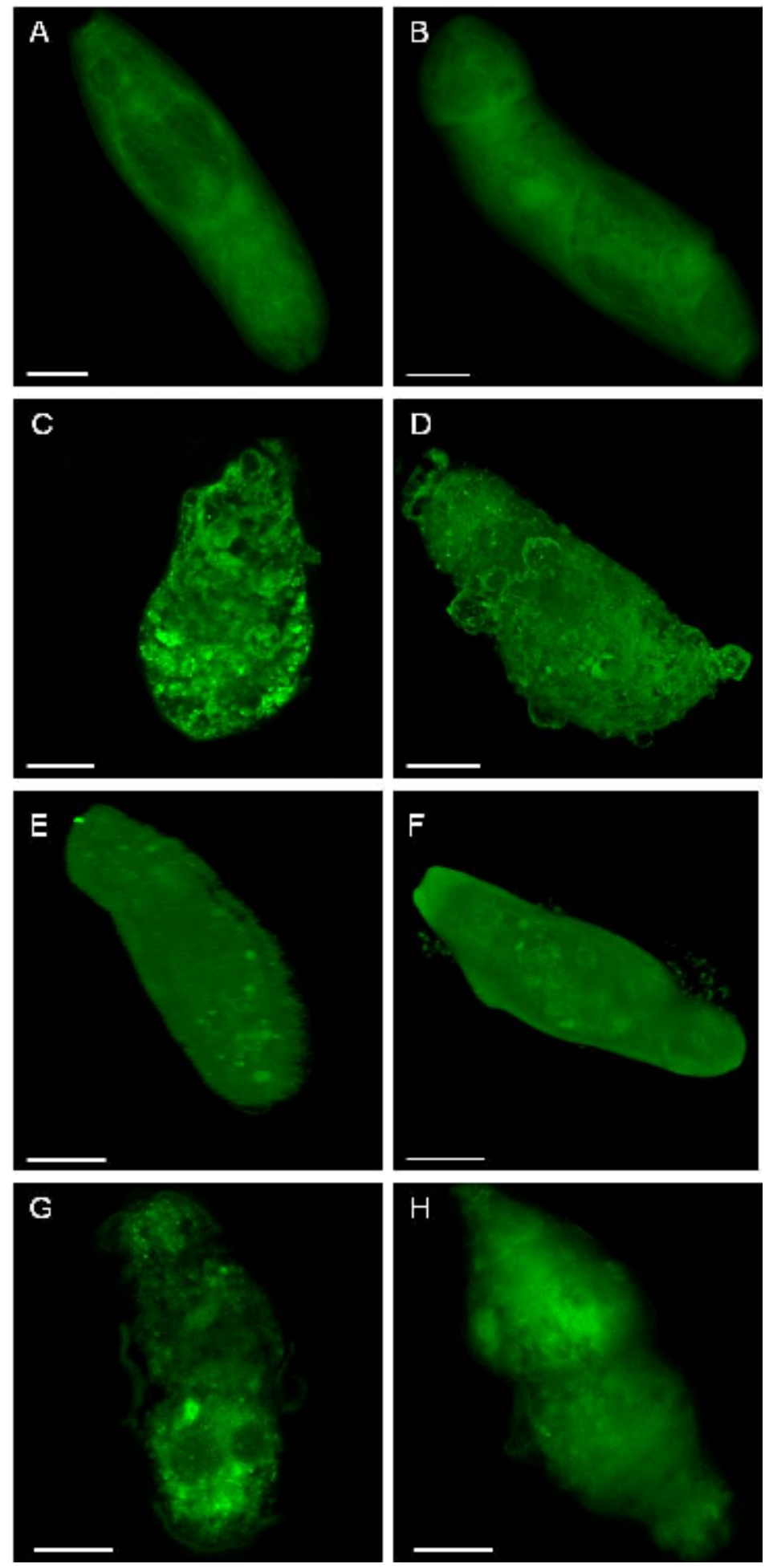

Figura 34. Efeito da piplartina, dermaseptina 01 e piperina nos esquistossômulos, recém transformados (A, C, E e G) e sete dias de idade (B, D, F e H), de Schistosoma mansoni. Os esquistossômulos foram incubados em meio 169 contendo os compostos. Após 120 horas ou ocorrência de morte, os parasitas foram fixados em solução AFA e monitorados com microscopia confocal. A e B: controle, sem adição de composto, após 120 horas. C e D: piplartina $25 \mu \mathrm{g} / \mathrm{ml}$, após 24 horas. E e F: dermaseptina $300 \mu \mathrm{g} / \mathrm{ml}$ após 24 horas. G e H: piperina $400 \mu \mathrm{g} / \mathrm{ml}$, após 48 horas. A-H: Imagens tridimensionais capturadas de microscópio confocal. Barras $=25 \mu \mathrm{m}$. 

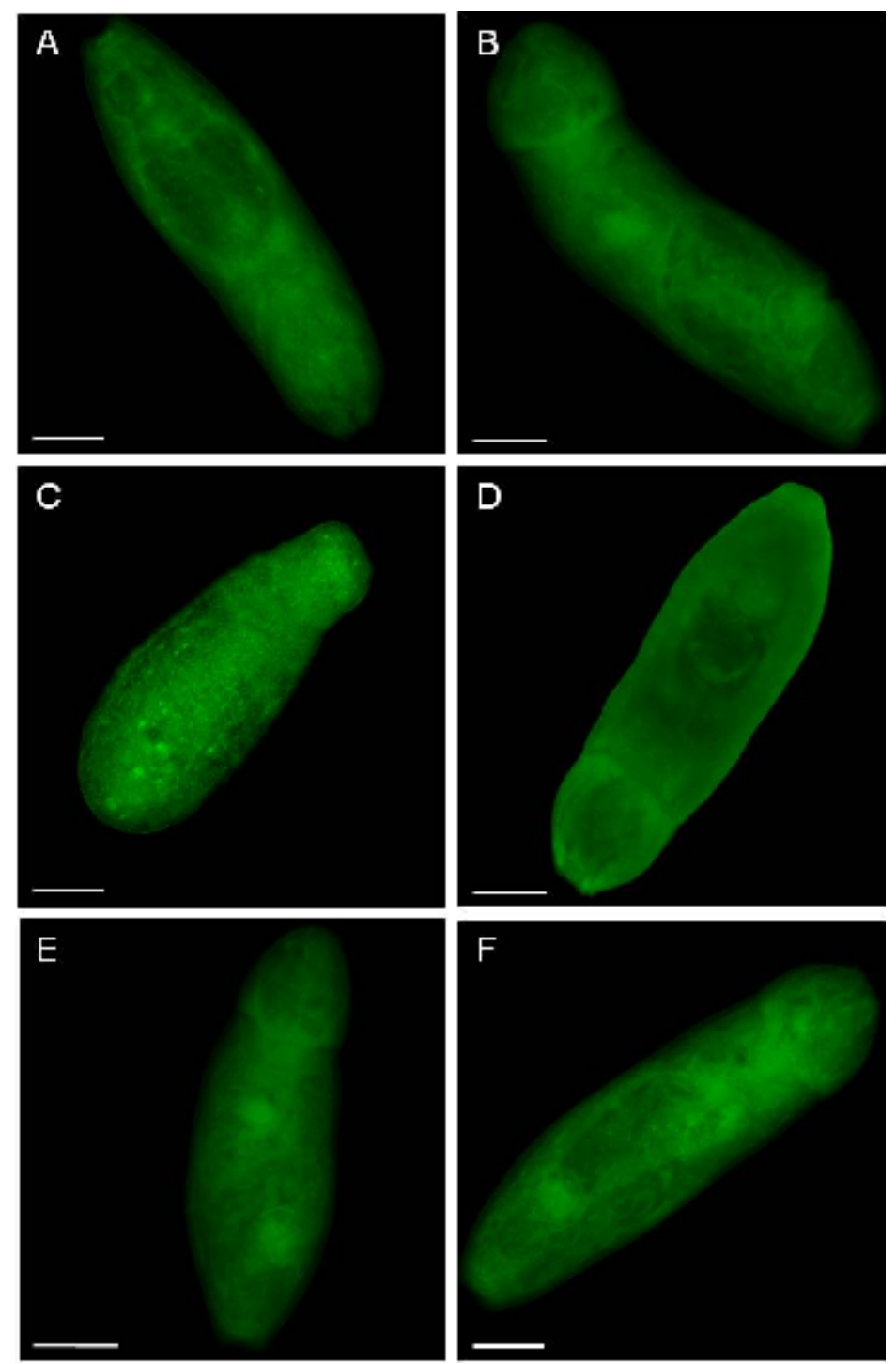

Figura 35. Efeito da epiisopiloturina e grandisina nos esquistossômulos, recém transformados (A, C, e E) e sete dias de idade (B, D e F), de Schistosoma mansoni. Os esquistossômulos foram incubados em meio 169 contendo os compostos. Após 120 horas ou ocorrência de morte, os parasitas foram fixados em solução AFA e monitorados com microscopia confocal. A e B: controle, sem adição de composto, após 120 horas. C e D: epiisopiloturina $400 \mu \mathrm{g} / \mathrm{ml}$, após 96 horas. E e F: grandisina 1000 $\mu \mathrm{g} / \mathrm{ml}$, após 120 horas. A-F: Imagens tridimensionais capturadas de microscópio confocal. Barras $=25 \mu \mathrm{m}$. 

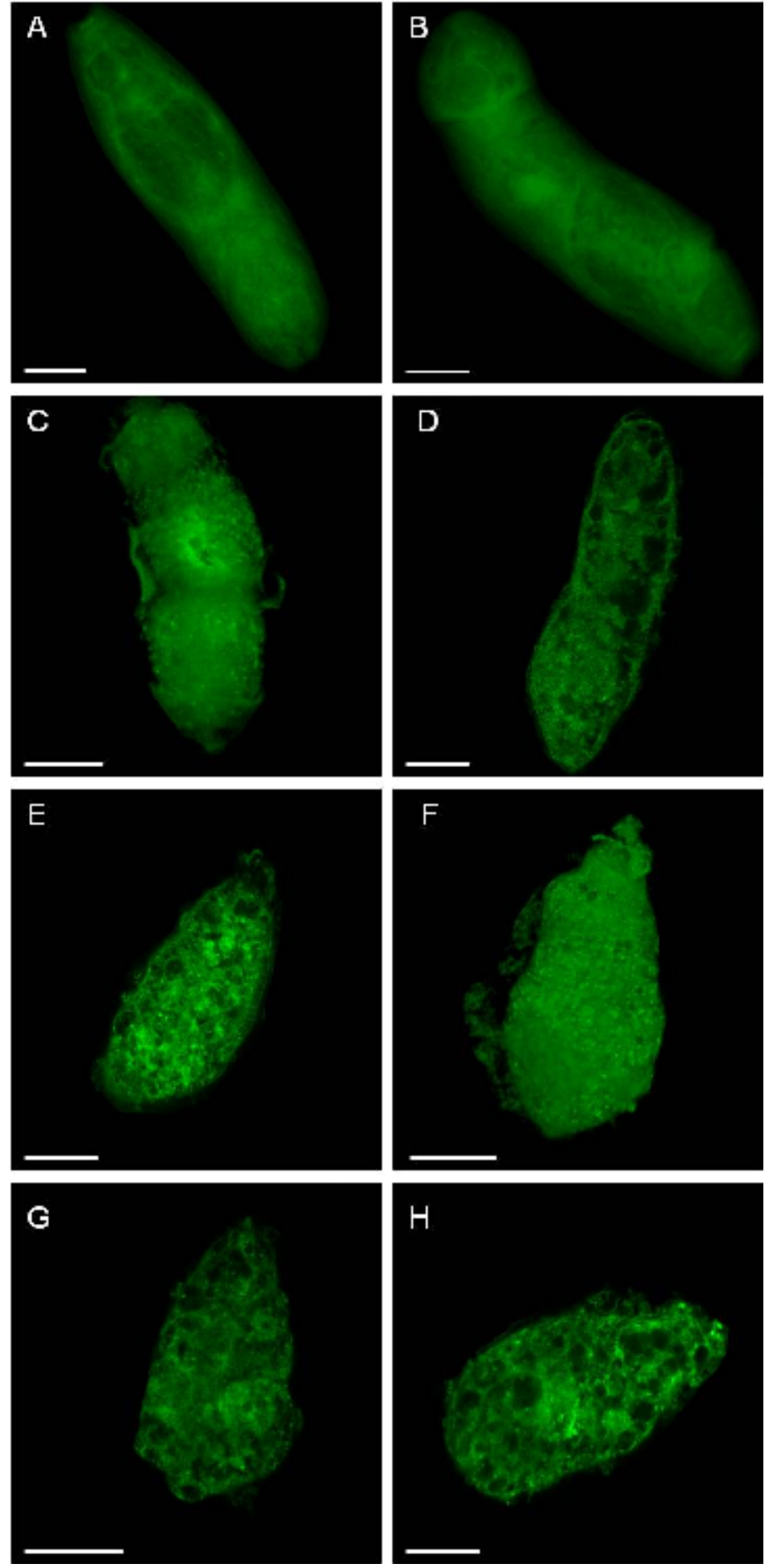

Figura 36. Efeito dos extratos de Piper tuberculatum, Piper crassinervium e Piper diospyrifolium nos esquistossômulos, recém transformados (A, C, E e G) e sete dias de idade (B, D, F e H), de Schistosoma mansoni. Os esquistossômulos foram incubados em meio 169 contendo os extratos. Após 120 horas ou ocorrência de morte, os parasitas foram fixados em solução AFA e monitorados com microscopia confocal. A e B: controle, sem adição de extrato, após 120 horas. C e D: $P$. tuberculatum $30 \mu \mathrm{g} / \mathrm{ml}$, após 24 horas. E e F: P. crassinervium $200 \mu \mathrm{g} / \mathrm{ml}$, após 24 horas. G e H: Piper diospyrifolium $100 \mu \mathrm{g} / \mathrm{ml}$, após 48 horas. A-H: Imagens tridimensionais capturadas de microscópio confocal. Barras $=25 \mu \mathrm{m}$. 

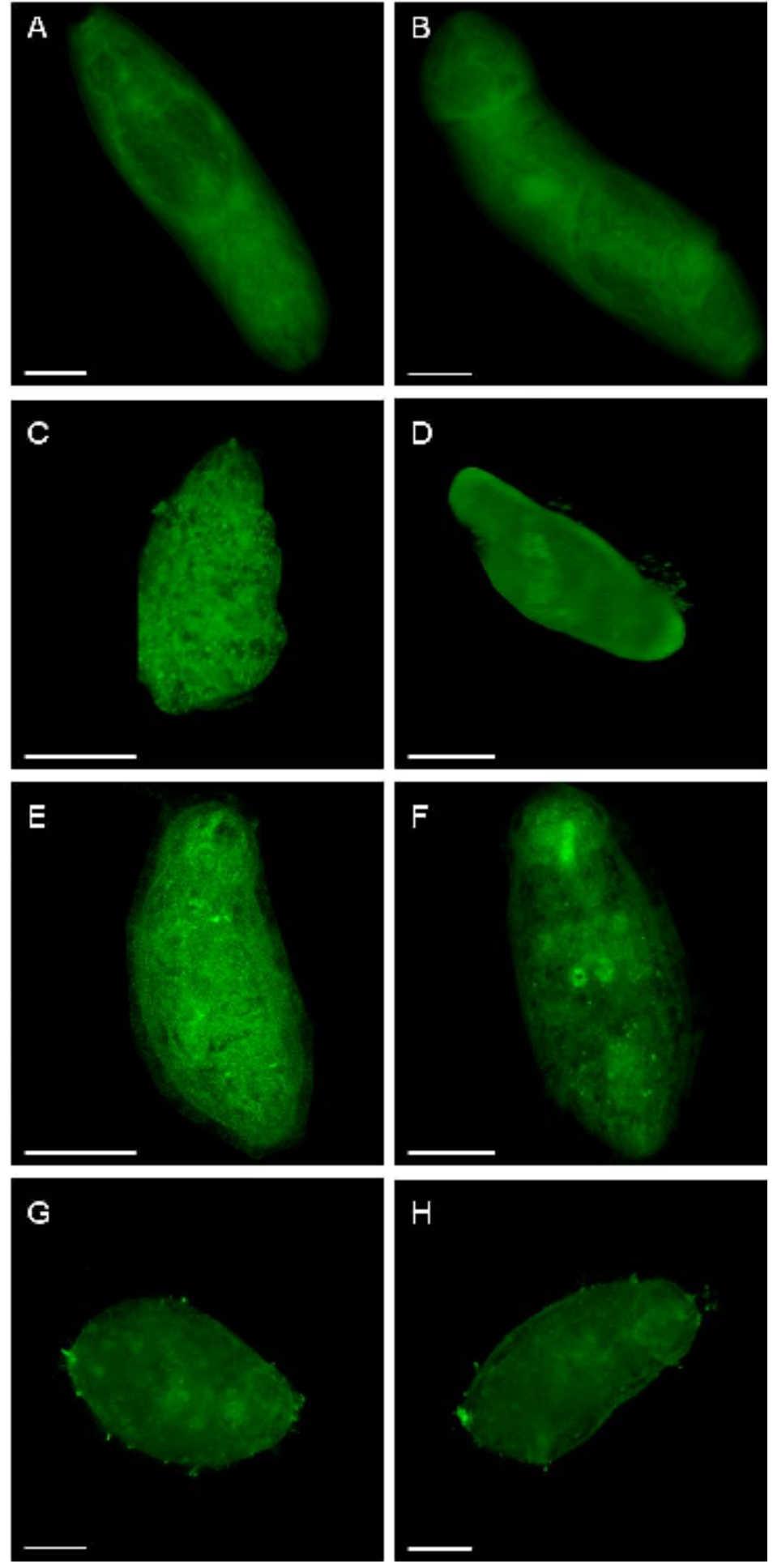

Figura 37. Efeito dos extratos de Piper fuligineum, Piper gaudichaudianum e Pothomorphe umbellata nos esquistossômulos, recém transformados (A, C, E e G) e sete dias de idade (B, D, F e H), de Schistosoma mansoni. Os esquistossômulos foram incubados em meio 169 contendo os extratos. Após 120 horas ou ocorrência de morte, os parasitas foram fixados em solução AFA e monitorados com microscopia confocal. A e B: controle, sem adição de extrato, após 120 horas. C e D: $P$. fuligineum $50 \mu \mathrm{g} / \mathrm{ml}$, após 24 horas. E e F: $P$. gaudichaudianum $150 \mu \mathrm{g} / \mathrm{ml}$, após 24 horas. G e H: $P$. umbellata $100 \mu \mathrm{g} / \mathrm{ml}$, após 24 horas. A-H: Imagens tridimensionais capturadas de microscópio confocal. Barras $=25 \mu \mathrm{m}$. 
A partir da penetração no hospedeiro mamífero, o tegumento do esquistossômulo se torna especializado para absorção, secreção e proteção do parasita. De fato, o esquistossômulo precisa se deslocar pelos tecidos e vasos do hospedeiro e não parece haver contestações de que esse deslocamento requer que os esquistossômulos vençam barreiras (MCKERROW e SALTER, 2002; CURWEN e WILSON, 2003). Assim como no verme adulto, o tegumento do esquistossômulo é um importante alvo para drogas. Durante estudos in vitro com Schistosoma japonicum expostos a mefloquina, a análise por microscopia de luz indicou que os parasitas com 3 horas e 7 dias de idade sofrem alterações no tegumento: pequenas bolhas e/ou superfície rugosa (XIAO; MEI; JIAO, 2009). Como apresentado em neste estudo, a análise por microscopia confocal mostrou que os compostos e extratos causaram alterações no tegumento dos esquistossômulos, com bolhas e rugosidade na superfície, de acordo com as observações de Xiao, Mei e Jiao (2009). 


\subsection{Toxicidade de compostos e extratos em células de mamífero}


Os extratos e compostos naturais utilizados neste estudo apresentaram atividade em vermes adultos e esquistossômulos de S. mansoni. O objetivo desta parte do trabalho foi avaliar a toxicidade dos compostos e extratos vegetais em célula de mamífero, utilizando células Vero (linhagem celular de rim de macaco), um modelo experimental para estudos de citotoxicidade (MCCLANE et al., 1984; EKWALL et al., 1990; BHUNIA e WAMPLER, 2005).

A viabilidade celular foi avaliada utilizando o método por cristal violeta (CRUZ; MENDONÇA; PETRICEVICH, 2005). Nos experimentos, as células Vero foram cultivadas em placas de cultura de 96 poços contendo compostos ou extratos em meio DMEM suplementado com $10 \%$ de soro a $37^{\circ} \mathrm{C}$, em atmosfera de $\mathrm{CO}_{2}$ a $5 \%$. Após 24, 48 e 72 horas, os sobrenadantes eram retirados e as células aderidas foram fixadas e coradas com cristal violeta $0,2 \%$ em metanol 20\%. A toxicidade era avaliada a partir da absorbância de poços controles, contendo células em meio DMEM com DMSO 0,2\%. Durante o todo o período de incubação as culturas foram monitoradas, diariamente, em microscópio invertido.

\subsubsection{Atividade citotóxica de compostos e extratos vegetais em células Vero}

Os resultados consolidados de pelo menos de três experimentos independentes, nos quais a toxicidade foi avaliada simultaneamente com todos os compostos e extratos vegetais, revelam que a toxicidade em células Vero foi dependente da concentração e dos produtos naturais ensaiados. As Figuras 38-43 apresentam os resultados da viabilidade das células Vero em presença de compostos e extratos, a diferentes concentrações, durante 24 h, 48 h e 72 h de incubação. Comparativamente às células incubadas apenas em meio de cultura, no término de período de incubação, isto é, 72 horas a redução da viabilidade celular foi significativa com o praziquantel $150 \mu \mathrm{g} / \mathrm{ml}(\mathrm{P}<$ $0,001)$, com os compostos piplartina $25 \mu \mathrm{g} / \mathrm{ml}(P<0,05)$, grandisina $1750 \mu \mathrm{g} / \mathrm{ml}(P<$ 0,05), bem como com os extratos de Piper tuberculatum $30 \mu \mathrm{g} / \mathrm{ml}(P<0,001)$, Piper crassinervium $150 \mu \mathrm{g} / \mathrm{ml}(\mathrm{P}<0,05)$, Piper diospyrifolium $300 \mu \mathrm{g} / \mathrm{ml}(\mathrm{P}<0,01)$ e Piper gaudichaudianum $500 \mu \mathrm{g} / \mathrm{ml}(P<0,05)$. Por outro lado, os compostos piperina, dermaseptina e epiisopiloturina, assim como os extratos de folhas de Piper fuligineum e Pothomorphe umbellata não apresentaram citotoxicidade nas concentrações avaliadas (Figuras 38-43). 
Prazicjuantel $24 \mathrm{~h}$

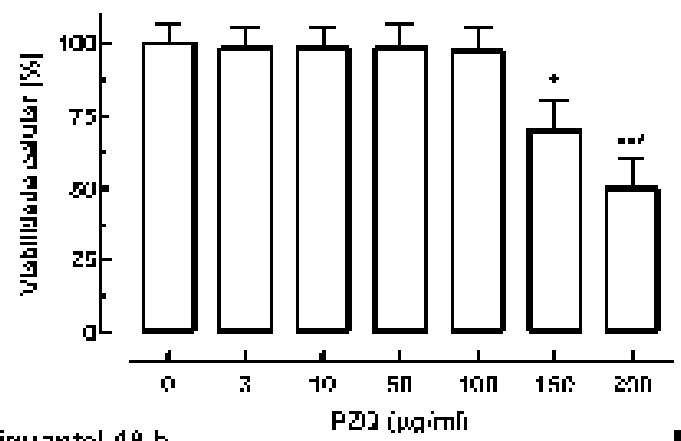

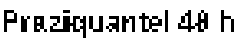

Praziquantel $72 \mathrm{~h}$
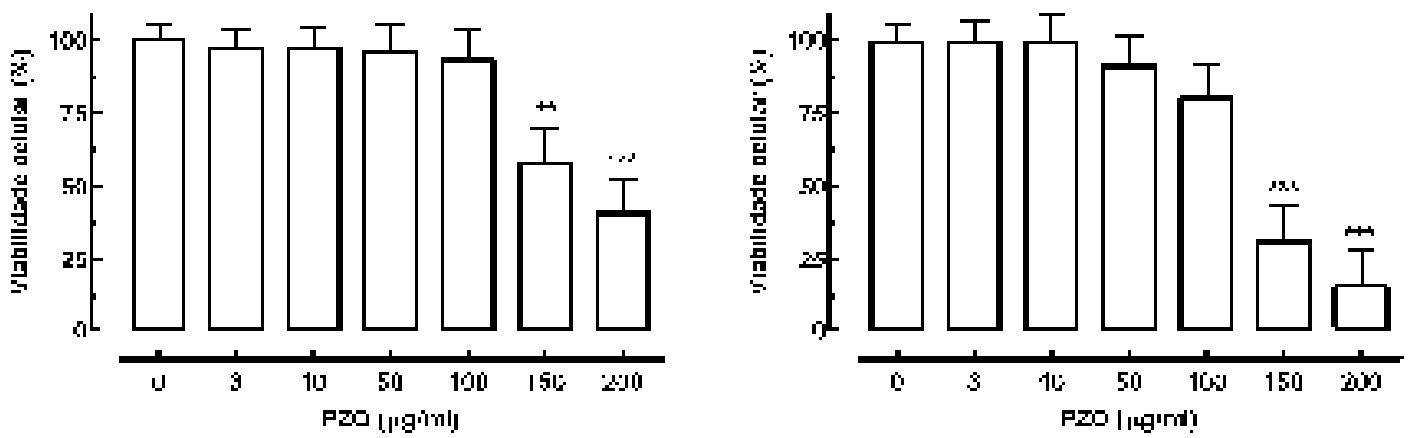

Fiplartina $24 \mathrm{~h}$
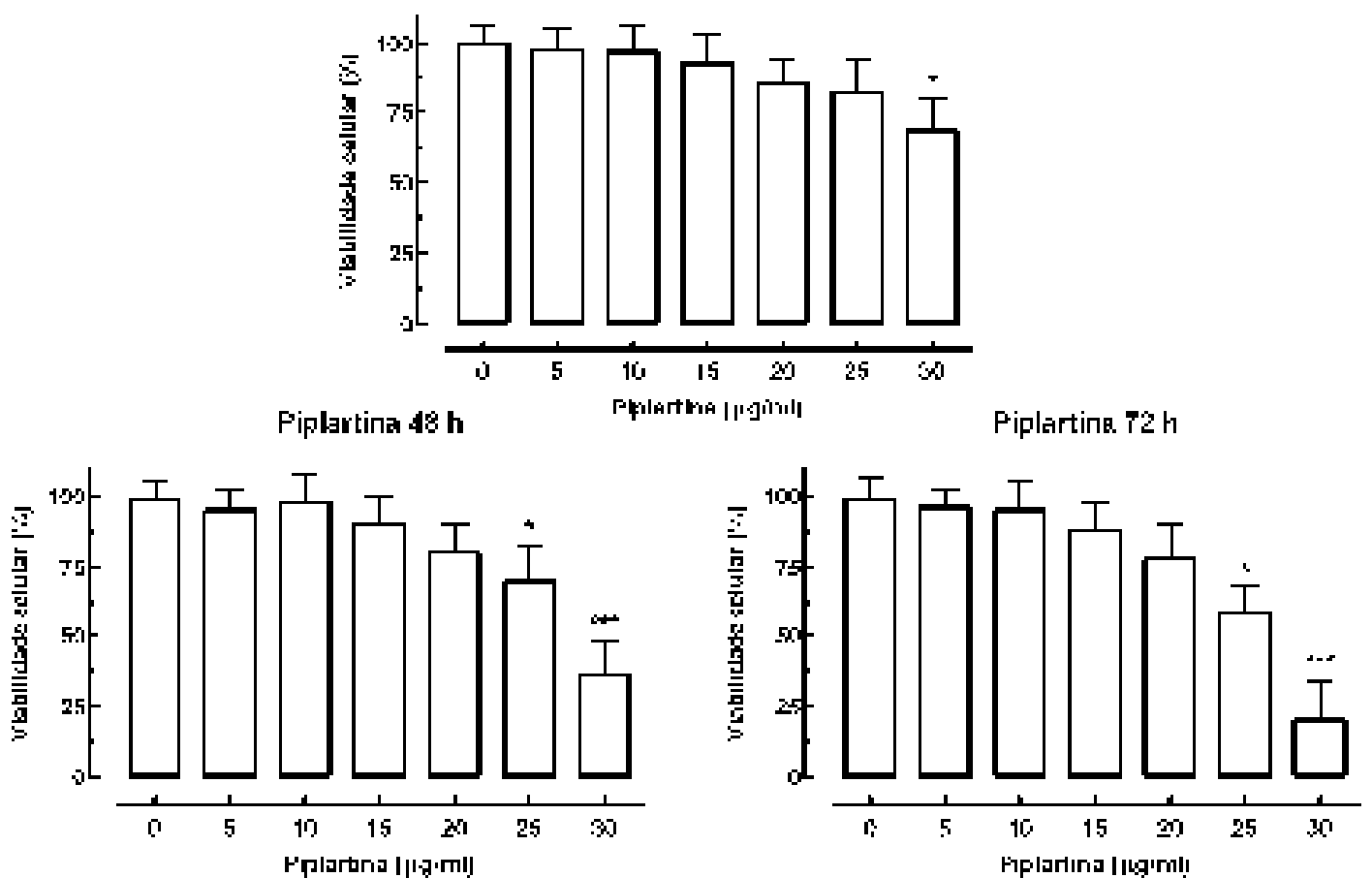

Figura 38. Viabilidade da célula Vero em presença de praziquantel e piplartina. As células foram crescidas em meio DMEM, contendo DMSO 0,2\%, em presença dos compostos nos tempos e concentrações indicadas. Após diferentes tempos, as células foram fixadas e coradas com cristal violeta em metanol. A viabilidade celular foi avaliada a partir da leitura das absorbâncias $(595 \mathrm{~nm})$. Os valores são média de três experimentos independentes feitos em triplicatas. As barras representam o desvio padrão da média. Diferença significativa entre o controle (DMEM contendo DMSO 0,2\%) e os grupos tratados com praziquantel (PZQ) e piplartina: *(P<0,05), **(P<0,01), ***(P< 0,001). 
[lermaseptin $24 \mathrm{~h}$

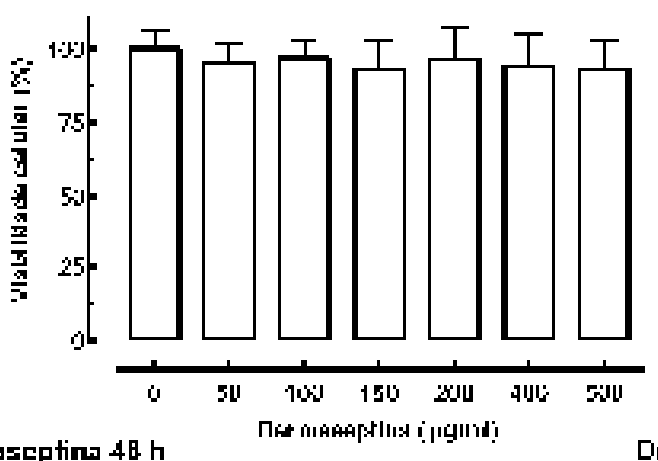

Dermascptins 4 B. h

Dermascplina $72 \mathrm{~h}$
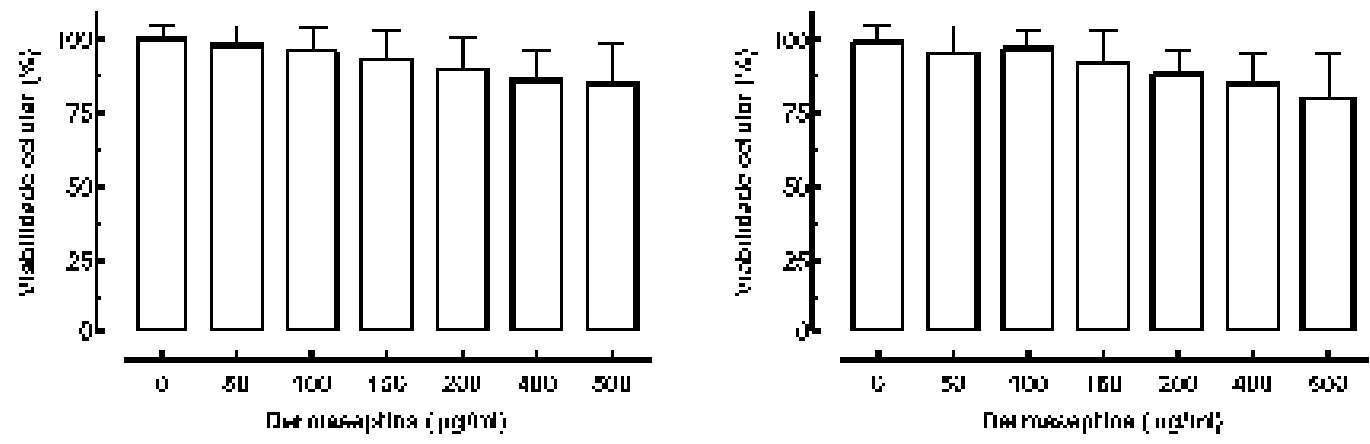

Epllsepilkturina 24 h
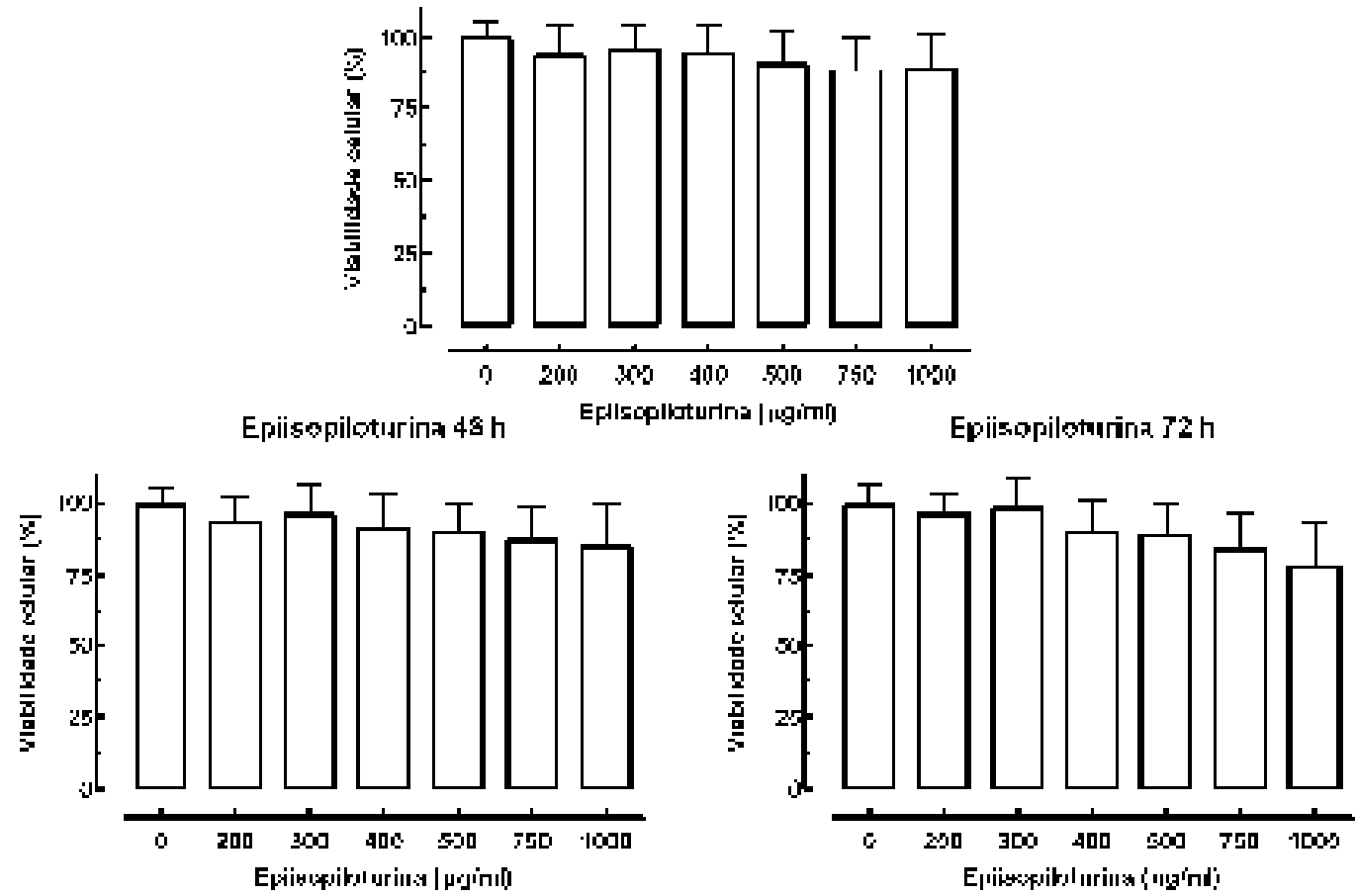

Figura 39. Viabilidade da célula Vero em presença de dermaseptina 01 e epiisopiloturina. As células foram crescidas em meio DMEM, contendo DMSO 0,2\%, em presença dos compostos nos tempos e concentrações indicadas. Após diferentes tempos, as células foram fixadas e coradas com cristal violeta em metanol. A viabilidade celular foi avaliada a partir da leitura das absorbâncias (595 nm). Os valores são média de três experimentos independentes feitos em triplicatas. As barras representam o desvio padrão da média. 
Piparim $24 \mathrm{~h}$

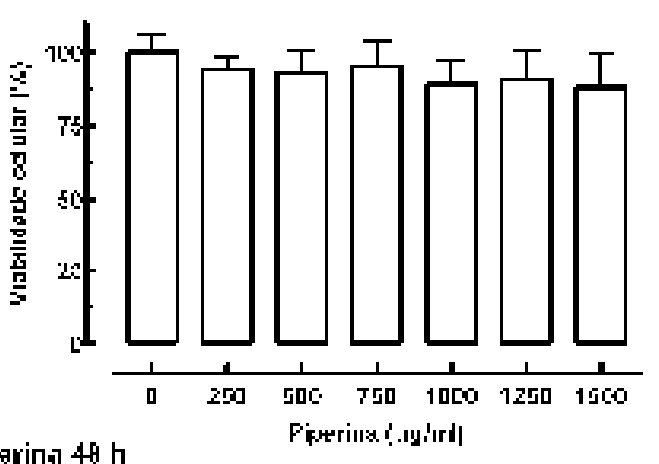

Piparina $4 \mathrm{H}$

Piparina $72 \mathrm{~h}$
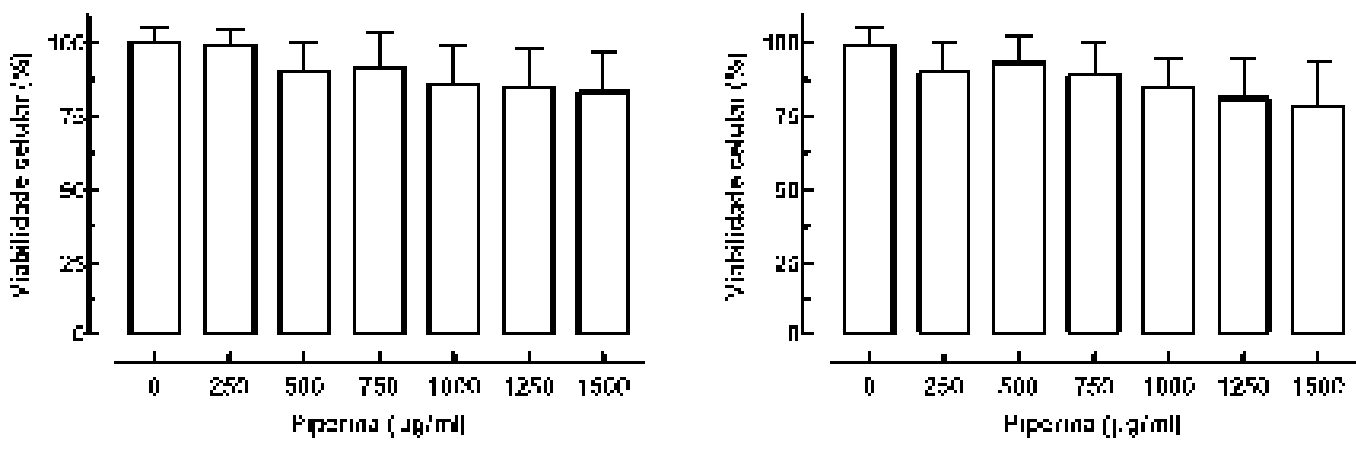

Grandisina $24 \mathrm{~h}$

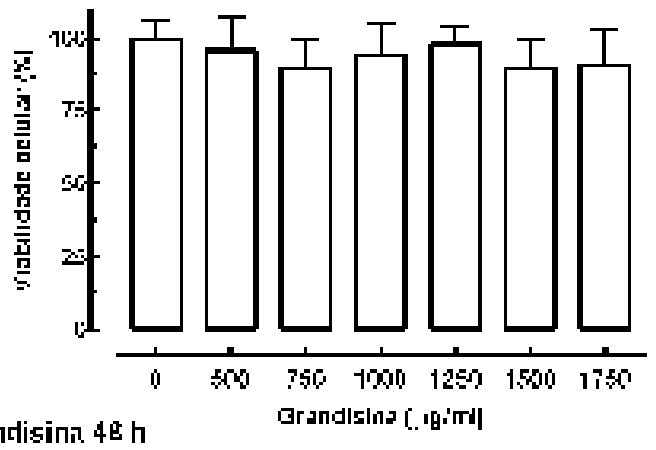

Grandising $72 \mathrm{~h}$
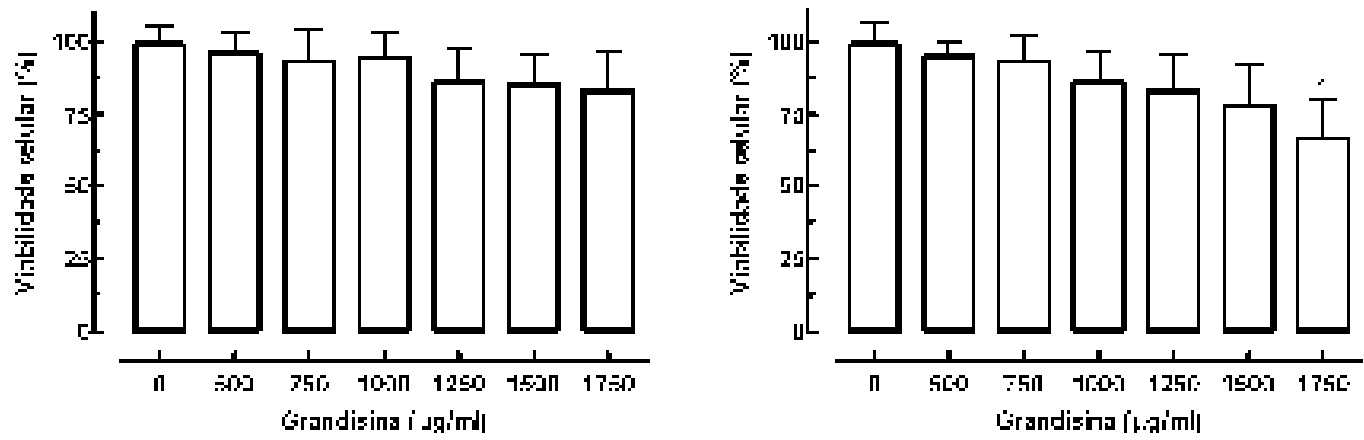

Figura 40. Viabilidade da célula Vero em presença de piperina e grandisina. As células foram crescidas em meio DMEM, contendo DMSO 0,2\%, em presença dos compostos nos tempos e concentrações indicadas. Após diferentes tempos, as células foram fixadas e coradas com cristal violeta em metanol. A viabilidade celular foi avaliada a partir da leitura das absorbâncias $(595 \mathrm{~nm})$. Os valores são média de três experimentos independentes feitos em triplicatas. As barras representam o desvio padrão da média. Diferença significativa entre o controle (DMEM contendo DMSO 0,2\%) e os grupos tratados com grandisina: $*(P<0,05)$. 
Proer wherthidur $24 \mathrm{~h}$

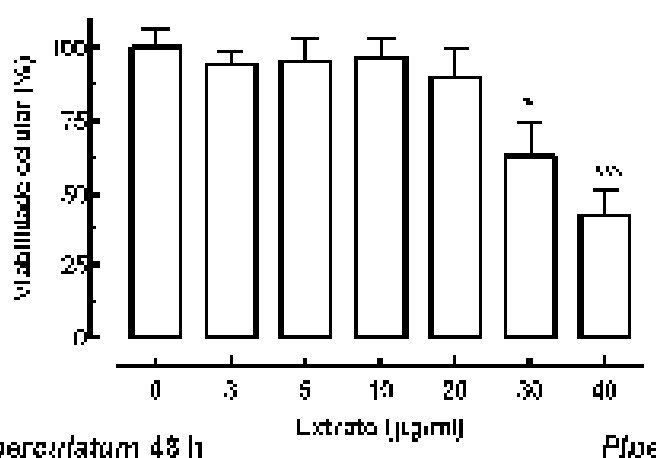

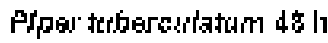

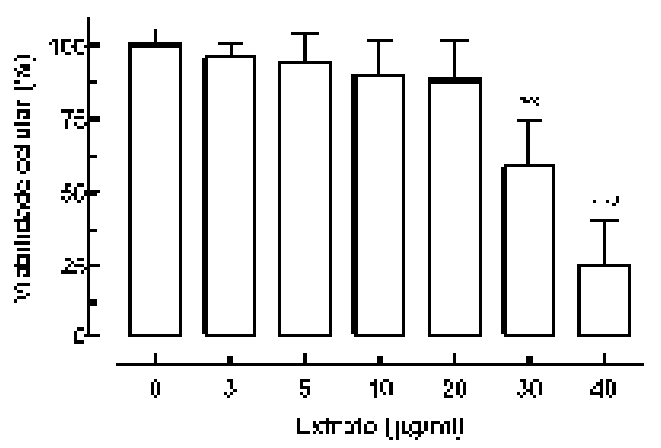

PJjer therawgtin $72 \mathrm{~h}$

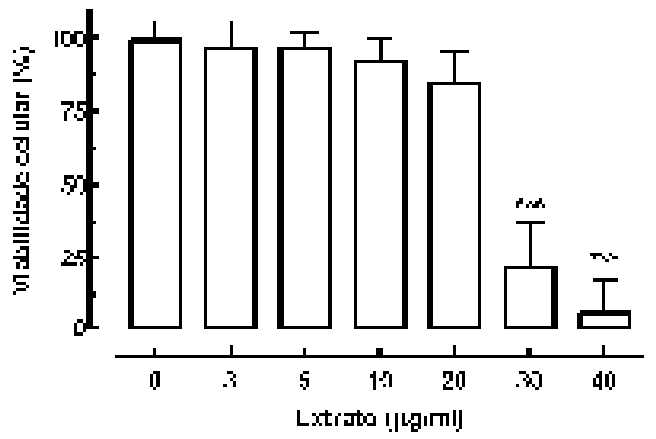

Pjper arosingritur $24 \mathrm{~h}$

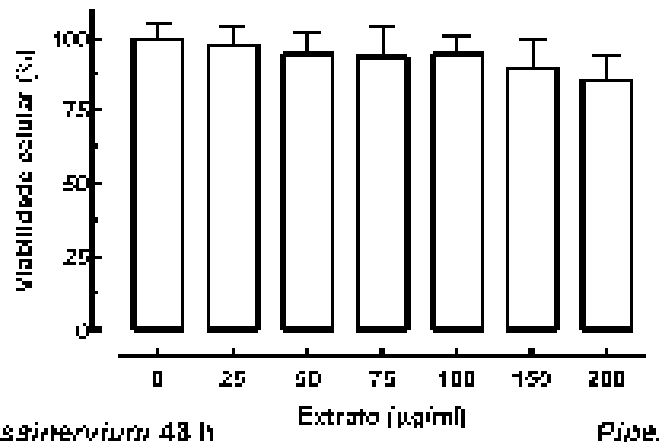

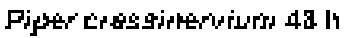

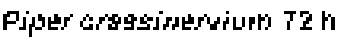
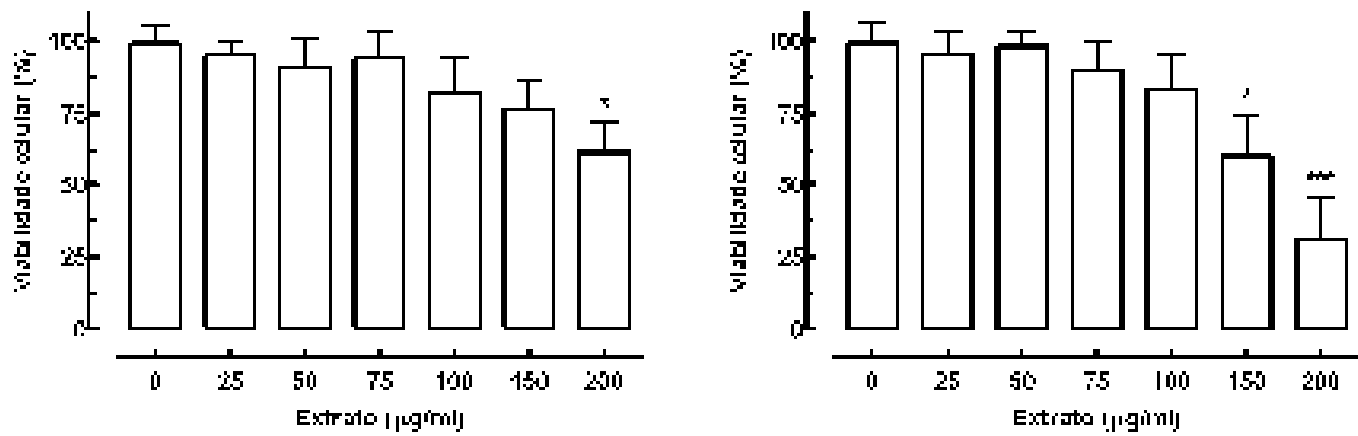

Figura 41. Viabilidade da célula Vero em presença de extratos de Piper tuberculatum e Piper crassinervium. As células foram crescidas em meio DMEM, contendo DMSO $0,2 \%$, em presença dos extratos nos tempos e concentrações indicadas. Após diferentes tempos, as células foram fixadas e coradas com cristal violeta em metanol. A viabilidade celular foi avaliada a partir da leitura das absorbâncias (595 nm). Os valores são média de três experimentos independentes feitos em triplicatas. As barras representam o desvio padrão da média.

Diferença significativa entre o controle (DMEM contendo DMSO 0,2\%) e os grupos tratados com extratos vegetais: $*(P<0,05), * *(P<0,01)$, ***(P<0,001). 
Prber diospytrolistr 24 h

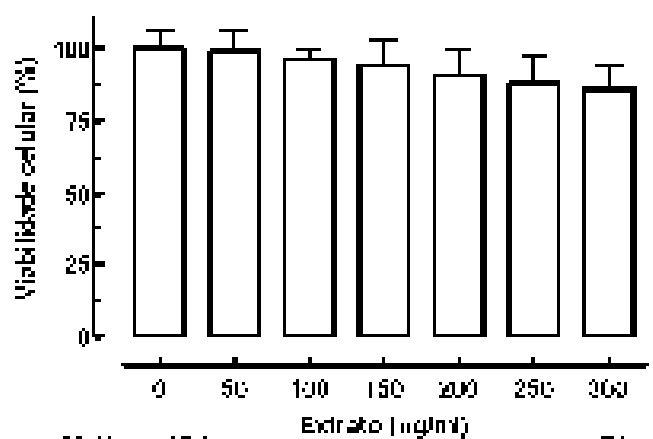

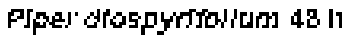

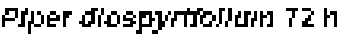
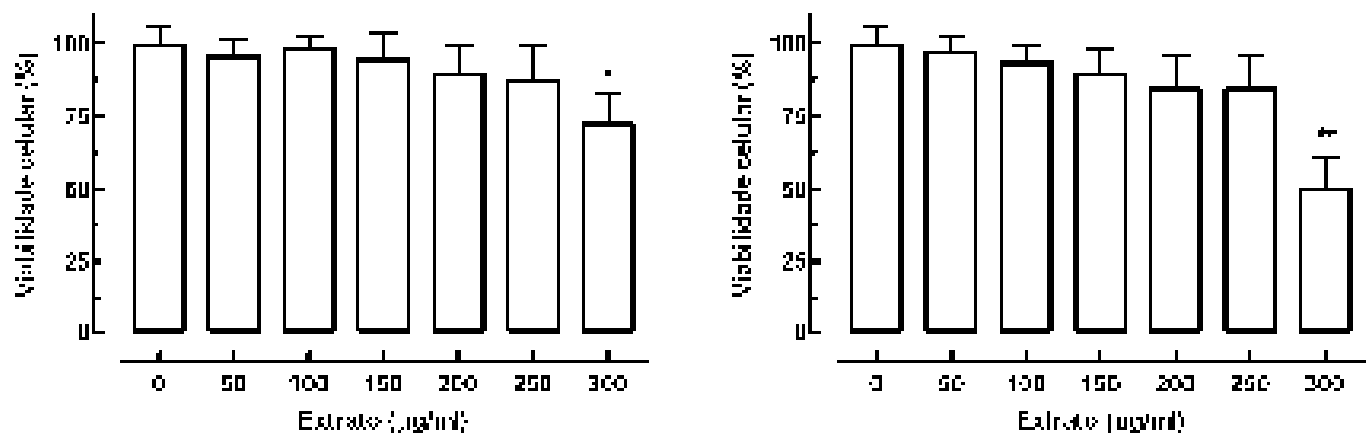

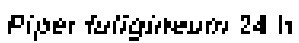

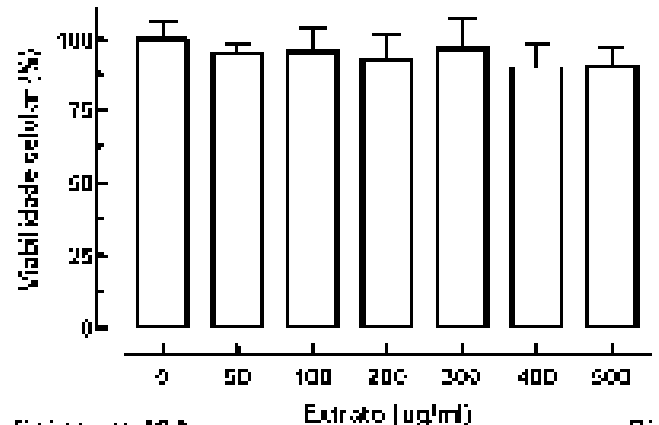

Pjpher ferligirlesush dgh

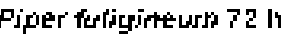
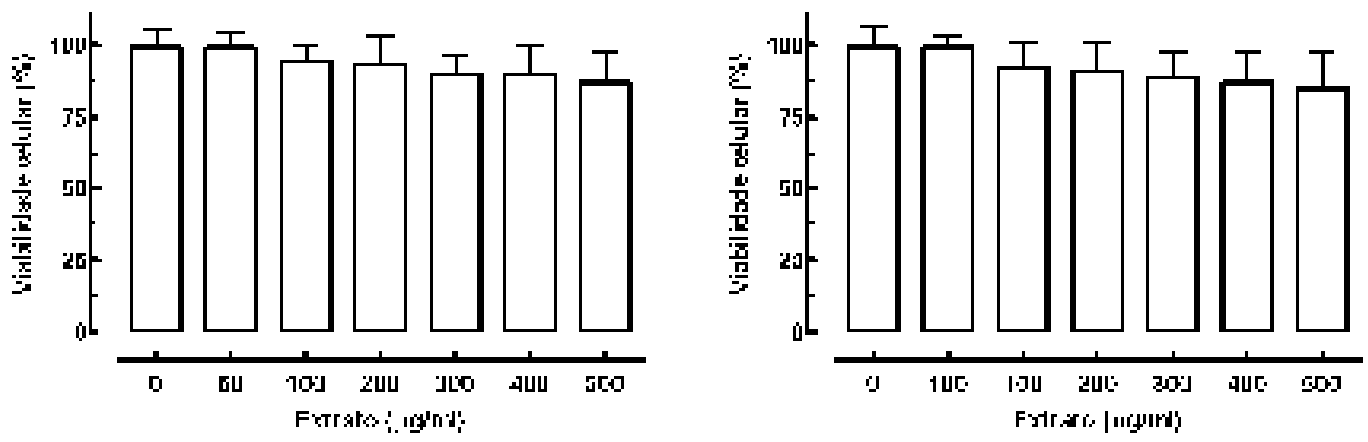

Figura 42. Viabilidade da célula Vero em presença de extratos de Piper diospyrifolium e Piper fuligineum. As células foram crescidas em meio DMEM, contendo DMSO 0,2\%, em presença dos extratos nos tempos e concentrações indicadas. Após diferentes tempos, as células foram fixadas e coradas com cristal violeta em metanol. A viabilidade celular foi avaliada a partir da leitura das absorbâncias (595 nm). Os valores são média de três experimentos independentes feitos em triplicatas. As barras representam o desvio padrão da média.

Diferença significativa entre o controle (DMEM contendo DMSO 0,2\%) e os grupos tratados com extratos vegetais: $*(P<0,05)$, $* *(P<0,01)$. 


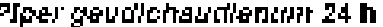

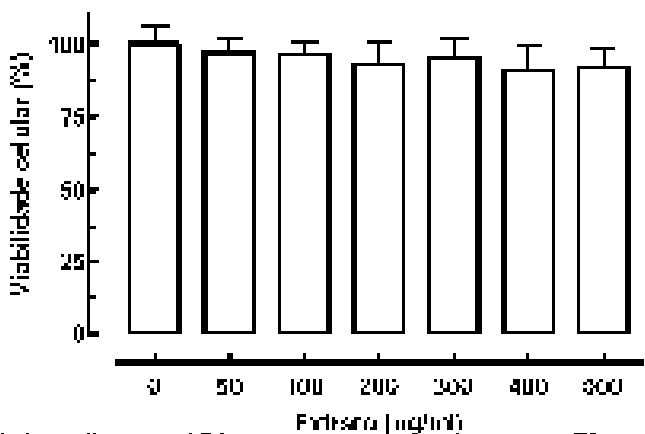

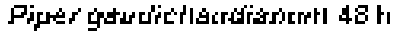

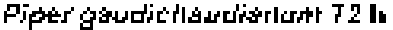
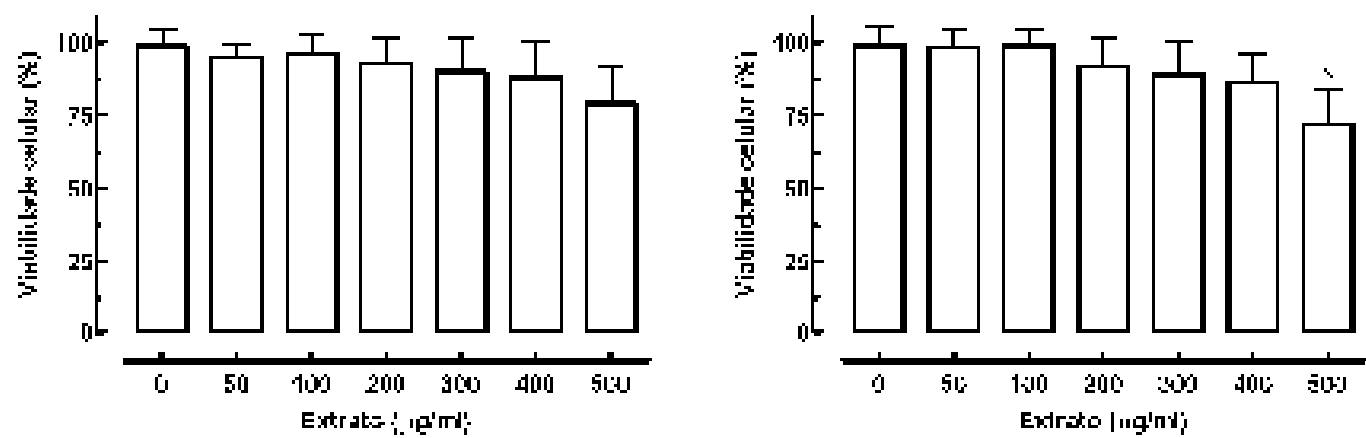

Fothomorphe umbelsate $24 \mathrm{~h}$

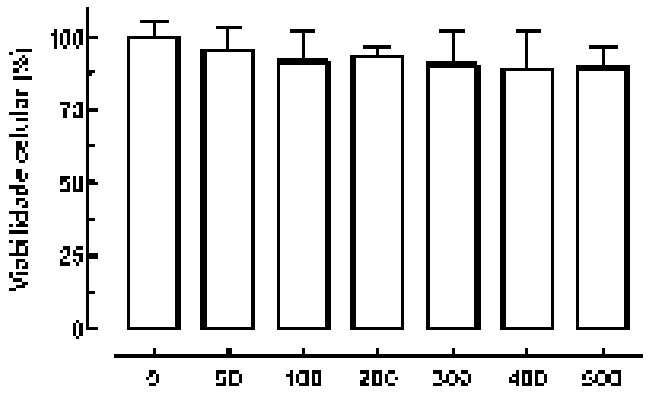

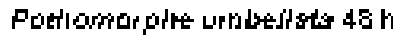

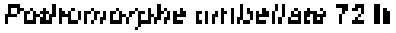
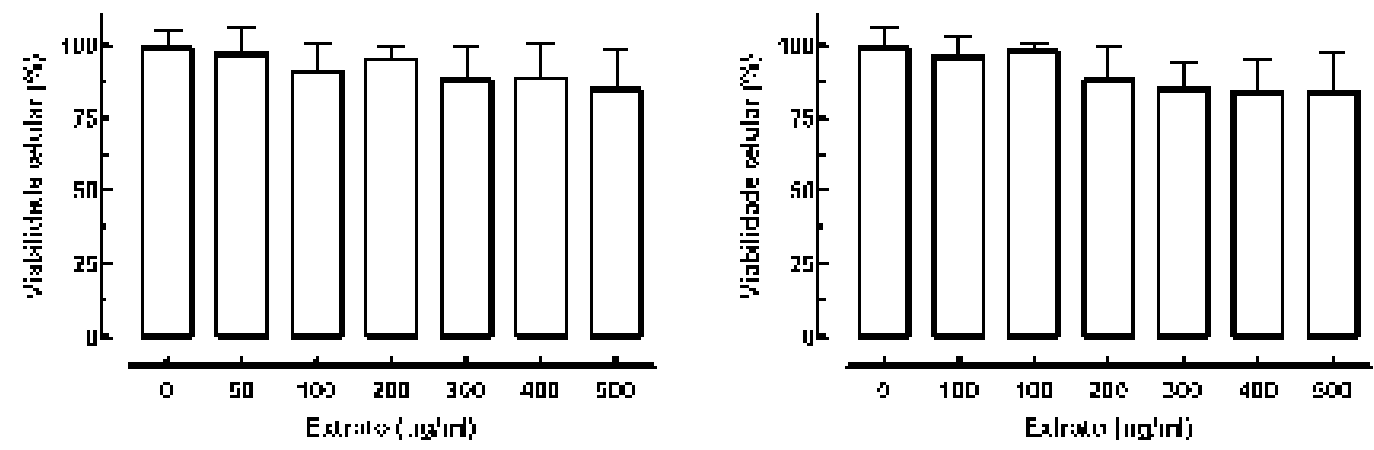

Figura 43. Viabilidade da célula Vero em presença de extratos de Piper gaudichaudianum e Pothomorphe umbellata. As células foram crescidas em meio DMEM, contendo DMSO $0,2 \%$, em presença dos extratos nos tempos e concentrações indicadas. Após diferentes tempos, as células foram fixadas e coradas com cristal violeta em metanol. A viabilidade celular foi avaliada a partir da leitura das absorbâncias (595 nm). Os valores são média de três experimentos independentes feitos em triplicatas. As barras representam o desvio padrão da média.

Diferença significativa entre o controle (DMEM contendo DMSO 0,2\%) e os grupos tratados com extratos vegetais: $*(P<0,05)$. 
Considerando somente as concentrações letais aos vermes adultos e esquistossômulos de S. mansoni (ver Tabela 6, 42 e 43), somente o praziquantel, na menor concentração $100 \%$ letal para esquistossômulos $(150 \mu \mathrm{g} / \mathrm{ml})$, foi citotóxico quando comparado com o grupo controle. Desta forma, todos os compostos e extratos vegetais utilizados neste estudo apresentam atividade em esquistossomos sem afetar a viabilidade das células de mamífero. De fato, a citotoxicidade de alguns compostos e extratos só foi verificada em concentrações de aproximadamente dez vezes maior que a dose capaz de matar $100 \%$ dos esquistossomos, como é o caso da amida piplartina e dos extratos de Piper crassinervium, Piper diospyrifolium e Piper gaudichaudianum.

Corroborando os resultados deste trabalho, a ausência da toxicidade em células de mamífero já foi relatada com alguns compostos avaliados neste estudo. O peptídeo antimicrobiano dermaseptina apresenta amplo espectro de atividade (antibacteriana, anfifúngica e antiprotozoária) sem afetar a viabilidade de células de mamífero, como hemácias e leucócitos (BRAND et al., 2002). O alcaloide epiisopiloturina apresenta ação antiparasitária em amastigotas de Leishmania amazonensis e não é tóxico para as células peritoniais (MIURA et al., 2010; prelo). A amida piplartina possui atividade seletiva contra células tumorais, mas não afeta os leucócitos mononucleares quando avaliada na concentração de $10 \mu \mathrm{g} / \mathrm{ml}$, tampouco causa hemólise em células de mamíferos na concentração de até $200 \mu \mathrm{g} / \mathrm{ml}$ (BEZERRA, 2005; BEZERRA et al., 2007). A amida piperina também possui atividade seletiva contra células tumorais (PRADEEP e KUTTANE, 2002; SUNILA e KUTTAN, 2004; BEZERRA et al., 2006) e possui diversas atividades biológicas, particularmente antiprotozoária, sem afetar a viabilidade de macrófagos peritoniais (RIBEIRO et al., 2004); além disso, essa amida não causa hemólise (BEZERRA, 2005), e sua toxicidade foi avaliada em camundongos apresentando ausência de toxicidade para fígado e rim, além de não ser capaz de alterar significativamente os parâmetros hematológicos (CARDOSO et al., 2005). Espécies de Piperaceae têm sido utilizadas na alimentação e, também, na medicina tradicional devido ao acúmulo de diferentes classes de metabólitos biologicamente ativos. Muito provavelmente, devido a baixa toxicidade, esses vegetais são usados em muitas regiões do mundo (PARMAR et al., 1997; PRASAD et al., 2005). 


\subsection{Considerações finais}


A esquistossomose continua sendo um dos principais problemas mundiais de saúde pública, especialmente na maioria dos países africanos, asiáticos e alguns países da América Central e América do Sul. Apesar dos esforços em controlar a esquistossomose, esta helmintose continua a ocupar, após a malária, a segunda posição no mundo entre as parasitoses, em termos de extensão de áreas endêmicas e quantidade de pessoas infectadas. Esta doença afeta crianças, jovens, gestantes e grupos populacionais que se locomovem para áreas endêmicas. Tornou-se um fato regular em muitas partes do mundo, sendo associada ao aumento de temperatura do globo, à decadência dos sistemas de saúde, aos movimentos populacionais massivos e à resistência aos quimioterápicos que o parasita apresenta. Para obter-se sucesso no desafio que a questão da esquistossomose representa, há a necessidade de esforços do sistema de saúde, em particular, através da pesquisa e desenvolvimento de novas drogas. Isso facilitaria o controle da parasitose, além de eliminar a mortalidade e diminuir a morbidade (CHITSULO et al., 2000; FENWICH et al., 2003; FENWICH e WEBSTER, 2006; STEINMANN et al., 2006).

Os agentes etiológicos da esquistossomose possuem uma biologia muito interessante, pois passam por diversas fases e vivem em hospedeiros e ambientes diversificados, com uma incrível capacidade de adaptação, multiplicação e resistência. Os parasitas estão muito bem adaptados em seu hospedeiro, podendo viver até mais de 30 anos e, desta forma, desenvolveram mecanismos eficientes de evasão ao sistema imune, resultando, portanto, em uma infecção crônica debilitante que pode persistir por décadas (GRYSEELS et al., 2006).

A vacinação contra a esquistossomose tem sido pesquisada em muitos países, mas ainda não se obteve uma vacina eficiente em função da complexidade do ciclo de vida dos parasitas dentro de seus hospedeiros e, também, pela diversidade de respostas imune que eles geram (DUPRÉ et al., 2001; MCMANUS e LOUCAS, 2008). A maior dificuldade no desenvolvimento de uma vacina contra a esquistossomose tem sido a escolha de antígenos definidos que estimulem uma resposta imune apropriada induzindo a resistência (YANG et al., 2001). Além disso, mesmo com o desenvolvimento de uma vacina no futuro, o tratamento com fármaco não deixaria de ser empregado. Do ponto de vista estratégico e operacional, o tratamento com drogas causaria uma redução na carga parasitária em curto prazo, ao passo que a vacina produziria proteção de longo prazo (BERGQUIST et al., 2002; 2005). No entanto, até o momento, a quimioterapia ainda é a principal forma de controle da esquistossomose (HAGAN et al., 2004; CAFFFREY, 2007).

Considerada uma doença negligenciada, a esquistossomose tem recebido pouco investimento em pesquisa sobre novas drogas nas últimas décadas. De fato, com apenas um fármaco disponível para o tratamento, o praziquantel, a quimioterapia da esquistossomose pode estar agora em um ponto crucial (CIOLI; PICA-MATTOCCIA; 
ARCHER, 1993, 1995; CIOLI, 1998; FENWICK et al., 2003; BROOKER et al., 2006; FENWICK e WEBSTER, 2006). Contar com apenas um fármaco é, certamente, situação perigosa, especialmente no que diz respeito à resistência. É preocupante que linhagens de $S$. mansoni, em algumas áreas, parecem mostrar certo grau de resistência ao fármaco amplamente empregado (CIOLI; PICA-MATTOCCIA; ARCHER, 1993, 1995; CIOLI, 1998; ISMAIL et al., 1999; DOENHOFF et al., 2002; FENWICH et al., 2006). Dessa forma, há reconhecida necessidade de se desenvolver novos fármacos esquistossomicidas, sendo necessária a identificação de compostos potenciais para se executar um planejamento racional. A Organização Mundial de Saúde (OMS) incluiu a esquistossomose na sua lista de doenças negligenciadas, havendo destaque quanto à necessidade de pesquisa de novos fármacos. Nesse contexto, a OMS vem incentivando a bioprospecção para o encontro de esquistossomicidas (REMME et al., 2002; FENWICK et al., 2003; NOËL, 2008).

O Schistosoma mansoni é a espécie usada como modelo para triagem de novas drogas (KEISER, 2010). No presente estudo avaliou-se a toxicidade de 4 compostos isolados de espécies vegetais, as amidas piplartina e piperina, a lignana grandisina e o alcaloide epiisopiloturina; 1 composto isolado da pele de anfíbio, o peptídeo antimicrobiano dermaseptina 01 , e de 6 extratos etanólicos obtidos de plantas da família Piperaceae (Piper tuberculatum, P. crassinervium, P. diospyrifolium, P. fuligineum, P. gaudichaudianum e Pothomorphe umbellata) em adultos (machos e fêmeas com 49 dias de idade) e esquistossômulos (recém-transformados, 1, 3, 5 e 7 dias de idade) de Schistosoma mansoni. Em particular, o interesse por esses compostos e extratos vegetais baseia-se no fato de serem plantas de fácil propagação, ciclo reprodutivo curto, ampla distribuição geográfica, assim como a facilidade no isolamento de seus metabólitos secundários. Além disso, esses vegetais são comumente usados na medicina popular em muitas regiões do mundo (PALMAR et al., 1997; JARAMILLO e MANOS, 2001; PRASAD et al., 2005; KATO e FURLAN, 2007). Quanto à dermaseptina 01, segundo José Roberto Leite, 2010 (comunicação pessoal; UFPI, Parnaíba, PI) apesar da dificuldade de purificar a dermaseptina da secreção cutânea de anfíbio, esse peptídeo antimicrobiano já é sintetizado há cerca de 8 anos, o que facilita, portanto, sua aquisição.

Os resultados deste estudo, com esquistossômulos e adultos de S. mansoni, mostraram que os compostos e extratos reduziram a motilidade e causaram a morte dos parasitas com alterações morfológicas no tegumento, cujos efeitos são diretamente dependentes da concentração, do tempo de incubação e da idade dos helmintos (recémtransformados, 1, 3, 5, 7 e 49 dias de idade). Nas concentrações subletais notou-se, ainda, redução na oviposição. Além disso, nas concentrações letais aos esquistossomos, os compostos e extratos não apresentaram toxicidade em células de mamífero (célula Vero). Pela contagem de tubérculos em uma área conhecida da região dorsal dos 
helmintos machos, apresentamos, também, um modelo experimental que avalia quantitativamente o efeito de drogas no tegumento.

Em conjunto, baseado nos ensaios in vitro com S. mansoni, os resultados com os compostos e extratos apresentaram três aspectos importantes, a saber: a) curativa, pois são tóxicas aos parasitas adultos; b) profilática, pois são tóxicas as formas jovens (esquistossômulos); e c) supressora, pois reduzem ou impedem a oviposição. Apesar de promissores, os resultados foram obtidos de ensaios in vitro. É fato que os resultados de testes in vitro com muitas drogas não correspondem ao que se observa in vivo, mas, por outro lado, o teste in vitro é um importante passo para a triagem de potenciais drogas para o controle da esquistossomose (RAMIREZ et al., 2007; KEISER, 2010), como mostrado nos ANEXOS A, B e C.

A avaliação da atividade terapêutica, usando camundongo, principal modelo para os estudos in vivo (RAMIREZ et al., 2007; KEISER, 2010), com alguns compostos deverá ser explorado futuramente. O estudo do oograma, associado a quantidade e distribuição dos vermes são os métodos preferidos para avaliação da triagem de drogas in vivo (PELLEGRINO et al., 1962; PELLEGRINO e KATZ, 1968). Nessa fase dos ensaios interessa, também, conhecer a menor dose eficaz, os possíveis efeitos colaterais e tóxicos, a melhor via de administração e a ação sobre as diferentes fases evolutivas do verme.

Finalmente, para triagem de drogas, modificações químicas estruturais em compostos promissores, como a piplartina, estão em andamento para que, por intermédio de ensaios, se chegue à definição da melhor relação estrutura/atividade dessa amida. Neste sentido, o nosso grupo está trabalhando em colaboração com o Prof. Dr. Massuo J. Kato (IQ-USP). 
6 CONCLUSÃO 
1. Todos os compostos e extratos ensaiados causaram alterações na viabilidade das diferentes fases evolutivas do Schistosoma mansoni (esquistossômulos recémtransformados, 1, 3, 5 e 7 dias de idade; e adultos, machos e fêmeas com 49 dias de idade). Os compostos e extratos reduziram a motilidade e causaram a morte dos parasitas de forma diretamente dependente da concentração, do tempo de incubação e da fase evolutiva do verme.

2. Considerando os compostos e extratos ensaiados, a amida piplartina, o peptídeo dermaseptina e o extrato das folhas de Piper tuberculatum foram os que apresentaram efeito esquistossomicida em menor concentração para os vermes adultos e esquistossômulos. No geral, a atividade helminticida dos produtos naturais em esquistossômulos ocorreu em concentrações menores do que o observado com o praziquantel.

3. A autofluorescência dos esquistossomos permite a análise morfológica do parasita por microscopia confocal sem a presença de um fluoróforo. Desta forma, a contagem de tubérculos em parasitas machos é um modelo experimental que avalia, quantitativamente, o efeito de drogas no tegumento do Schistosoma mansoni.

4. Nas concentrações letais, os compostos, exceto grandisina, e extratos causaram alterações morfológicas no tegumento dos esquistossômulos e adultos. A análise quantitativa, feita por microscopia confocal em vermes adultos, revelou que os danos nos tubérculos ocorrem de forma dose-dependente.

5. Os extratos e compostos causaram contração nos esquistossômulos, independentemente da idade, previamente ao efeito antiparasitário.

6. Nas concentrações subletais, exceto grandisina e o extrato de Piper gaudichaudianum, os compostos e extratos causaram redução na oviposição dos parasitas, de forma diretamente dependente da concentração. Os compostos dermaseptina e epiisopiloturina, assim como o extrato das folhas de Piper crassinervium inibiram, em quase $100 \%$, a postura das fêmeas.

7. Nas concentrações letais para adultos e esquistossômulos, os compostos e extratos não apresentam toxicidade para células de mamífero (células Vero). Em alguns casos, a viabilidade celular foi reduzida somente em concentrações aproximadamente dez vezes superior à dose mínima capaz de matar $100 \%$ dos parasitas. Por outro lado, o praziquantel é citotóxico na concentração letal para os esquistossômulos. 
REFERÊNCIAS 


\section{REFERÊNCIAS*}

ABDULLA, M. H.; LIM, K. C.; SAJID, M.; MCKERROW, J. H.; CAFFREY, C. R. Schistosomiasis mansoni: novel chemotherapy using a cysteine protease inhibitor. PLoS Med., v. 4, p. e14, 2007.

ABDULLA, M. H.; RUELAS, D. S.; WOLFF, B.; SNEDECOR, J.; LIM, K. C.; XU, F.; RENSLO, A. R.; WILLIAMS, J.; MCKERROW, J. H.; CAFFREY, C. R. Drug discovery for schistosomiasis: hit and lead compounds identified in a library of known drugs by medium-throughput phenotypic screening. PLoS Negl. Trop. Dis., v. 3, p. e478, 2009.

AHN, Y. J.; LEE, S. B.; LEE, H. S.; KIM, G. H. Insecticidal and acaricidal activity of carvacrol and beta-thujaplicine derived from Thujopsis dolabrata var. hondai sawdust. J. Chem. Ecol., v. 24, p. 81-90, 1998.

AMARAL, R.; TAUIL, P. L.; LIMA, D. D.; ENGELS, D. An analysis of the impact of the schistosomiasis control programme in Brazil. Mem. Inst. Oswaldo Cruz, v. 101, p. 79-85, 2006. Suppl. 1.

ANDRADE, Z. A.; dos SANTOS, H. A.; BOROJEVIC, R.; GRIMAUD, J. A. Lesões hepáticas produzidas por hycanthone (Etrenol). Rev. Inst. Med. Trop. S. Paulo, v. 16, p. 160-170, 1974.

ANDRADE-NETO, M.; SILVEIRA, E. R.; BRAZ-FILHO, R.; GAMBARDELA, M. T. P.; SANTOS, R. H. A. 24-methyl-25-ethyldammarane derivatives from Pilocarpus spicatus. Phytochemistry, v. 35, p. 739-743, 1994.

ARAÚJO, N.; KOHN, A.; OLIVEIRA, Á. A.; KATZ, N. Schistosoma mansoni: ação da lovastatina no modelo murino. Rev. Soc. Bras. Med. Trop., v. 35, p. 35-38, 2002.

AURIAULT, C.; OUAISSI, M. A.; TORPIER, G.; EISEN, H.; CAPRON, A. Proteolytic cleavage of IgG bound to the Fc receptor of Schistosoma mansoni schistosomula. Parasite Immunol., v. 3, p. 33$44,1981$.

AURIAULT, C.; PIERCE, R.; CESARI, I. M.; CAPRON, A. Neutral protease activities at different developmental stages of Schistosoma mansoni in mammalian hosts. Comp. Biochem. Physiol. B, v. 72, p. 377-384, 1982.

BARR, S. G.; WARNER, K. L.; KORNREIC, B. G.; PISCITELLI, J.; WOLFE, A. A cysteine protease inhibitor protects dogs from cardiac damage during infection by Trypanosoma cruzi. Antimicrob. Agents Chemother., v. 49, p. 5160-5161, 2005.

BASCH, P. F. Cultivation of Schistosoma mansoni in vitro. I. Establishment of cultures from cercariae and development until pairing. J. Parasitol., v. 67, p. 179-185, 1981a.

BASCH, P. F. Cultivation of Schistosoma mansoni in vitro. II. Production of infertile eggs by worm pairs cultured from cercariae. J. Parasitol., v. 67, p. 186-190, 1981b.

BASCH P. F.; HUMBERT R. Cultivation of Schistosoma mansoni in vitro. III. Implantation of cultured worms into mouse mesenteric veins. J. Parasitol., v. 67, p. 191-195, 1981.

* De acordo com:

ASSOCIAÇÃO BRASILEIRA DE NORMA TÉCNICAS. NBR 6023: informação e documentação: referências: elaboração. Rio de Janeiro, 2002. 
BATISTA, J. M. Jr.; LOPES, A. A.; AMBRÓSIO, D. L.; REGASINI, L. O.; KATO, M. J.; BOLZANI, V. DAS.; CICARELLI, R. M. B.; FURLAN, M. Natural chromenes and chromene derivatives as potential anti-trypanosomal agents. Biol. Pharm. Bull., v. 31, p. 538-540, 2008.

BERGQUIST, N. R. Schistosomiasis vaccine development: progress and prospects. Mem. Inst. Oswaldo Cruz, v. 93, p. 95-101, 1998. Suppl. 1.

BERGQUIST, N. R. Schistosomiasis: from risk assessment to control. Trends Parasitol., v. 18, p. 309-314, 2002.

BERGQUIST, N. R.; Leonardo, L. R.; Mitchell, G. F. Vaccine-linked chemotherapy: can schistosomiasis control benefit from an integrated approach? Trends Parasitol., v. 21, p. 112$117,2005$.

BEZERRA, D. P. Potencial anticâncer da piplartina e piperina, amidas isoladas de plantas do gênero Piper, 2005. 140 f. Dissertação (Mestrado em Farmacologia) - Departamento de Fisiologia e Farmacologia, Universidade Federal do Ceará, Fortaleza, 2005.

BEZERRA, D. P.; PESSOA, C.; DE MORAES, M. O.; SILVEIRA, E. R.; LIMA, M. A.; ELMIRO, F. J.; COSTA-LOTUFO, L. V. Antiproliferative effects of two amides, piperine and piplartine, from Piper species. Z. Naturforsch. C, v. 60, p. 539-543, 2005.

BEZERRA, D. P.; CASTRO, F.O.; ALVES, A. P.; PESSOA, C.; MORAES, M. O.; SILVEIRA, E. R. ; LIMA, M. A.; ELMIRO, F. J.; COSTA-LOTUFO, L. V. In vivo growth-inhibition of Sarcoma 180 by piplartine and piperine, two alkaloid amides from Piper. Braz. J. Med. Biol. Res., v. 39, p. 801-807, 2006.

BEZERRA, D. P.; MILITÃO, G. C.; DE CASTRO, F. O.; PESSOA, C.; DE MORAES, M. O. ; SILVEIRA, E. R.; LIMA, M. A.; ELMIRO, F. J.; COSTA-LOTUFO, L. V. Piplartine induces inhibition of leukemia cell proliferation triggering both apoptosis and necrosis pathways. Toxicol. in Vitro, v. 21, p.1-8, 2007.

BeZERRA, D. P.; DE CASTRO, F. O.; ALVES, A. P.; PESSOA, C.; DE MORAES, M. O.; SILVEIRA, E. R.; LIMA, M. A.; ELMIRO, F. J.; DE ALENCAR, N. M.; MESQUITA, R. O.; LIMA, M. W.; COSTALOTUFO, L. V. In vitro and in vivo antitumor effect of 5-FU combined with piplartine and piperine. J. Appl. Toxicol., v. 28, p. 156-163, 2008.

BHUNIA, A. K.; WAMPLER, J. L. Animal and cell culture models for foodborne bacterial pathogens. In: FRATAMICO, P. M.; BHUNIA, A. K.; SMITH, J. L. Foodborne pathogens: microbiology and molecular biology. Norfolk, UK: Caister Academic Press, 2005. p. 15-32.

BLANCHARD, T. J. Schistosomiasis. Travel Med. Infect. Dis., v. 2, p. 5-11, 2004.

BLANTON, R. E.; LICATE, L. S. Developmental regulation of protein synthesis in schistosomes. Mol. Biochem. Parasitol., v. 51, p. 201-208, 1992.

BLEICHER, K. H.; BÖHM, H. J.; MÜLLER, K.; ALANINE, A. I. Hit and lead generation: beyond highthroughput screening. Nat. Rev. Drug Discov., v. 2, p. 369-378, 2003.

BOISSIER, J.; COSLÉDAN, F.; ROBERT, A.; MEUNIER, B. In vitro activities of trioxaquines against Schistosoma mansoni. Antimicrob. Agents Chemother., v. 53, p. 4903-4906, 2009. 
BODIWALA, H. S.; SINGH, G.; SINGH, R. ; DEY, C. S.; SHARMA, S. S.; BHUTANI, K. K.; SINGH, I. P. Antileishmanial amides and lignans from Piper cubeba and Piper retrofractum. J. Nat. Med., v. 61, p. $418-421,2007$.

BOUT, D. T.; DESLÉE, D.; CAPRON, A. Protection against schistosomiasis produced by cyclosporine A. Am. J. Trop. Med. Hyg., v. 33, p. 185-186, 1984.

BOUT, D.; DESLÉE, D.; CAPRON, A. Antischistosomal effect of cyclosporin A: cure and prevention of mouse and rat schistosomiasis mansoni. Infect. Immun., v. 52, p. 823-827, 1986.

BRAGUiNE, C. G.; COSTA, E. S.; MAGALHÃES, L. G.; RODRIGUES, V.; DA SILVA FILHO, A. A.; BASTOS, J. K.; SILVA, M. L.; CUNHA, W. R.; JANUÁRIO, A. H.; PAULETTI, P. M. Schistosomicidal evaluation of Zanthoxylum naranjillo and its isolated compounds against Schistosoma mansoni adult worms. Z. Naturforsch. C, v. 64, p. 793-797, 2009.

BRAND, G. D.; LEITE, J. R.; SILVA, L. P.; ALBUQUERQUE, S.; PRATES, M. V.; AZEVEDO, R. B.; CARREGARO, V.; SILVA, J .S.; SÁ, V. C.; BRANDÃO, R. A.; BLOCH, C. Jr. Dermaseptins from Phyllomedusa oreades and Phyllomedusa distincta. Anti-Trypanosoma cruzi activity without cytotoxicity to mammalian cells. J. Biol. Chem., v. 277, p. 49332-49340, 2002.

BRAND, G. D.; LEITE, J. R.; DE SÁ MANDEL, S. M.; MESQUITA, D. A.; SILVA, L. P.; PRATES, M. V.; BARBOSA, E. A.; VINECKY, F.; MARTINS, G. R.; GALASSO, J. H.; KUCKELHAUS, S. A.; SAMPAIO, R. N.; FURTADO, J. R. JR.; ANDRADE, A. C.; BLOCH, C. Jr. Novel dermaseptins from Phyllomedusa hypochondrialis (Amphibia) Biochem. Biophys. Res. Commun., v. 347, p. 739-746, 2006.

BRASIL. Ministério da Saúde. Secretaria de Vigilância em Saúde. Guia de vigilância epidemiológica e controle da mielorradiculopatia esquistossomótica. Ministério da Saúde, Secretaria de Vigilância em Saúde (Série A. Normas e Manuais Técnicos). Brasília: Ministério da Saúde, 2006.

BRASIL. Gabinete do Ministro: Portaria N 104 de 25 de janeiro de 2011. Diário Oficial da União. Brasília, DF, n. 18, 26 de jan. 2011. Seção 1. p. 37-38.

BRAZ-FILHO, R.; SOUZA, M. P.; MATOS, M. E. O. Piplartine-dimer A, a new alkaloid from Piper tuberculatum. Phytochemistry, v. 20, p. 345-346, 1981.

BRITO, C. F.; OLIVEIRA, G. C.; OLIVEIRA, S. C. ; STREET, M.; RIENGROJPITAK, S.; WILSON, R. A.; SIMPSON, A. J.; CORREA-OLIVEIRA, R. Sm14 gene expression in different stages of the Schistosoma mansoni life cycle and immunolocalization of the Sm14 protein within the adult worm. Braz. J. Med. Biol. Res., v. 35, p. 377-381, 2002.

BROOKER, S.; CLEMENTS, A. C.; BUNDY, D. A. Global epidemiology, ecology and control of soiltransmitted helminth infections. Adv. Parasitol., v. 62, p. 221-261, 2006.

CABRAL, M. M.; ALENCAR, J. A.; GUIMARÃES, A. E.; KATO, M. J. Larvicidal activity of grandisin against Aedes aegypti. J. Am. Mosq. Control. Assoc., v. 25, p. 103-105, 2009.

CAFFREY, C. R. Chemotherapy of schistosomiasis: present and future. Curr. Opin. Chem. Biol., v. 11 , p. 433-439, 2007. 
CAPRON, A. R. Immunity to schistosomes. Curr. Opin. Immunol., v. 4, p. 419-424, 1992.

CAPRON, M. A.; WIEMER, D. F. Piplaroxide, an ant-repellent piperidine epoxide from Piper tuberculatum. J. Nat. Prod., v. 59, p. 794-795, 1996.

CARDOSO, J .F .R.; VIANA, E. B.; WARDINI, A. B.; EVANGELISTA, D. W.; LIMA, M. E. F.; SOARES, B. A.; BARRETO JUNIOR, C. B.; BRITO, M. F.; DANELLI, M. G. M.; MAZUR, C. Avaliação do efeito tóxico da piperina isolada da pimenta do reino (Piper nigrum L) em camundongos. Rev. Univ. Rural, Sér. Ci. Vida, v. 25, p. 85-91, 2005.

CARNEIRO-SANTOS P.; THORNHILL, J. A.; DOENHOFF, M. J.; HAGAN, P.; KUSEL, J. R. Acidic vesicles of Schistosoma mansoni. Parasitol. Res., v. 87, p. 1001-1006, 2001.

CARVALHO, A. A.; GALDINO, P. M.; NASCIMENTO, M. V.; KATO, M. J.; VALADARES, M. C.; CUNHA, L. C.; COSTA, E. A. Antinociceptive and antiinflammatory activities of grandisin extracted from Virola surinamensis. Phytother. Res., v. 24, p.113-118, 2010.

CENTRO DE VIGILÂNCIA EPIDEMIOLÓGICA DE SÃO PAULO. Divisão de doenças de transmissão hídrica e alimentar: dados estatísticos. São Paulo: CVE, 2005.

CHAPPELL, L. H.; THOMSON, A. W.; BARKER, G. C.; SMITH, S. W. G. Dosage, timing, and route of administration of cyclosporin $A$ and nonimmunosuppressive derivatives of dihydrocyclosporin $A$ and cyclosporin C against Schistosoma mansoni in vivo and in vitro. Antimicrob. Agents Chemother., v. 31, p. 1567-1571, 1987.

CHINCHAR, V. G.; BRYAN, L.; SILPHADAUNG, U.; NOGA, E.; WADE, D.; ROLLINS-SMITH, L. Inactivation of viruses infecting ectothermic animals by amphibian and piscine antimicrobial. Virology, v. 323, p. 268-275, 2004.

CHIPPAUX, J. P.; LE HESRAN, J. Y.; GARCIA, A.; BRASSEUR, P. Recent studies have reported significant toxicity of artemisinin and its derivatives for schistosomula in various Schistosoma species. Am. J. Trop. Med. Hyg., v. 69, p. 1-2, 2003.

CHIRAC, P.; TORREELE E. Global framework on essencial health R\&D. Lancet, v. 377, p. 1560$1561,2006$.

CHITSULO, L.; ENGELS, D.; MONTRESOR, A.; SAVIOLI, L. The global status of schistosomiasis and its control. Acta Trop., v. 77, p. 41-51, 2000.

CÍCERO BEZERRA FELIPE, F.; TRAJANO SOUSA FILHO, J.; DE OLIVEIRA SOUZA, L. E. ; ALEXANDRE SILVEIRA, J.; ESDRAS DE ANDRADE UCHOA, D.; ROCHA SILVEIRA, E.; DEUSDÊNIA LOIOLA PESSOA, O.; DE BARROS VIANA, G. S. Piplartine, an amide alkaloid from Piper tuberculatum, presents anxiolytic and antidepressant effects in mice. Phytomedicine, v. 14, p. 605-612, 2007.

CIOLI, D. Chemotherapy of schistosomiasis: an update. Parasitol. Today, v. 14, p. 418-421, 1998.

CIOLI, D. Praziquantel: is there real resistance and are there alternatives? Curr. Opin. Infect. Dis., v. 13, p. 659-663, 2000. 
CIOLI, D.; PICA-MATTOCCIA, L., Praziquantel. Parasitol. Res., v. 90, p. S3-S9, 2003.

CIOLI, D.; PICA-MATTOCCIA, L.; ARCHER, S. Drug resistence in schistosomes. Parasitol. Today, v. 9, p. $162-166,1993$.

CIOLI, D.; PICA-MATTOCCIA, L.; ARCHER, S. Antischistosomal drugs: past, present...and future? Pharmac. Ther., v. 68, p. 35-85, 1995.

CLARK, T. E.; APPLETON, C. C.; KVALSVIG, J. D. Schistosomiasis and the use of indigenous plant molluscicides: a rural South African perspective. Acta Trop., v. 66, p. 93-107, 1997.

COELHO, P. M.; LIMA e SILVA, F. C.; NOGUEIRA-MACHADO, J. A. Resistance to oxamniquine of a Schistosoma mansoni strain isolated from patient submitted to repeated treatments. Rev. Inst. Med. Trop. Sao Paulo., v. 39, p. 101-106, 1997.

COLES, G. C.; MUTAHI, W. T.; KINOTI, G. K.; BRUCE, J. I.; KATZ, N. Tolerance of Kenyan Schistosoma mansoni to oxamniquine. Trans. R. Soc. Trop. Med. Hyg., v. 81, p. 782-785, 1987.

CONCEIÇÃO, M. J.; ARGENTO, C. A.; CORRÊA, A. Study of Schistosoma mansoni isolates from patients with failure of treatment with oxamniquine. Mem. Inst. Oswaldo Cruz, v. 95, p. 375$380,2000$.

COLLEY, D. G.; WIKEL, S.K. Schistosoma mansoni: simplified method for the production of schistosomules. Exp. Parasitol., v. 35, p. 44-51, 1974.

COTINGUIBA, F.; REGASINI, L. O.; DA SILVA BOLZANI, V.; DEBONSI, H. M. ; DUÓ PASSERINI, G.; CICARELLI, R. M. B.; KATO, M. J.; FURLAN, M. Piperamides and their derivatives as potential antitrypanosomal agents. Med. Chem. Res., v. 18, p. 703-711, 2009.

CRABTREE, J. E.; WILSON, R. A. Schistosoma mansoni: a scanning electron microscope study of the developing schistosomulum. Parasitology, v. 81, p. 553-564, 1980.

CRUZ, A. H.; MENDONÇA, R. Z.; PETRICEVICH, V. L. Crotalus durissus terrificus venom interferes with morphological, functional, and biochemical changes in murine macrophage. Mediators Inflamm., v. 2005, p. 349-359, 2005.

CURWEN, R. S.; WILSON, R. A. Invasion of skin by schistosome cercariae: some neglected facts. Trends Parasitol., v. 19, p. 63-66, 2003.

CURWEN, R. S.; ASHTON, P. D.; SUNDARALINGAM, S.; WILSON, R. A. Identification of novel proteases and immunomodulators in the secretions of schistosome cercariae that facilitate host entry. Mol. Cell Proteomics, v. 5, p. 835-844, 2006.

Da SILVA, S. P.; NOËL, F. Time course of the effect of praziquantel on Schistosoma mansoni attachment in vitro: comparison with its effects on worm length and motility. Parasitol. Res., v. 81 , p. 543-548, 1995.

Da SILVA FILHO, A. A.; COSTA, E. S. ; CUNHA, W. R.; SILVA, M. L. NANAYAKKARA, N. P.; BASTOS, J. K. In vitro antileishmanial and antimalarial activities of tetrahydrofuran lignans isolated from Nectandra megapotamica (Lauraceae). Phytother. Res., v. 22, p. 1307-1310, 2008. 
DAGAN, A.; EFRON, L.; GAIDUKOV, L.; MOR, A.; GINSBURG, H. In vitro antiplasmodium effects of dermaseptin S4 derivatives. Antimicrob. Agents Chemother., v. 46, p. 1059-1066, 2002.

DAMONNEVILLE, M.; AURIAULT, C.; PIERCE, R. J.; CAPRON, A. Antigenic properties of Schistosoma mansoni aminopeptidases: evolution during the development in mammalian hosts. Mol. Biochem. Parasitol., v. 6, p. 265-275, 1982.

DAS, B. P.; CHOWDHURY, D. N.; CHOWDHURY, B.; DAS, G. K.; RAY, T. Studies on some alkaloides for toxicity on larvae of Culex quinquefascitus. Indian J. Environ. Health, v. 38, p. 81-85, 1996.

De ARAÚJO, S. C.; de MATTOS, A. C.; TEIXEIRA, H. F.; COELHO, P. M.; NELSON, D. L.; de OLIVEIRA, M. C. Improvement of in vitro efficacy of a novel schistosomicidal drug by incorporation into nanoemulsions. Int. J. Pharm., v. 337, p. 307-315, 2007.

De FERREIRA-DA-CRUZ, M.; ADAMI, Y. L.; da ESPINOLA-MENDES, E.; FIGUEIREDO, M. R.; DANIEL-RIBEIRO, C. T. The intraperitoneal Plasmodium berghei-Pasteur infection of Swiss mice is not a system that is able to detect the antiplasmodial activity in the Pothomorphe plant extracts that are used as antimalarials in Brazilian endemic areas. Exp. Parasitol., v. 94, p. 243-247, 2000.

De MELO, N. I.; MAGALHAES, L. G.; de CARVALHO, C. E.; WAKABAYASHI, K. A.; de P AGUIAR, G.; RAMOS, R. C.; MANTOVANI, A. L.; TURATTI, I. C.; RODRIGUES, V.; GROPPO, M.; CUNHA, W. R.; VENEZIANI, R. C.; CROTTI, A. E. Schistosomicidal activity of the essential oil of Ageratum conyzoides L. (Asteraceae) against adult Schistosoma mansoni worms. Molecules, v. 16, p. 76273, 2011.

De OliVeirA PENIDO, M. L.; ZECH COELHO, P. M.; de MELlO, R. T.; PILÓ-VELOSO, D.; de OLIVEIRA, M. C.; KUSEL, J. R.; NELSON, D. L. Antischistosoma activity of aminoalkanethiols, alkylaminoalkanethiosulfuric acids and the corresponding disulfides. Acta Trop., v. 108, 249-255, 2008.

De SOUZA DIAS, L. C.; de JESUS PEDRO, R.; DEBERALDINI E. R. Use of praziquantel in patients with schistosomiasis mansoni previously treated with oxamniquine and/or hycanthone: resistance of Schistosoma mansoni to schistosomicidal agents. Trans. R. Soc. Trop. Med. Hyg., v. 76, p. 652-659, 1982.

DIAS, L. C.; PEDRO, R. J.; RIGO, E.; GOTO, M. M.; MAFRA, G. L. A human strain of Schistosoma mansoni resistant to schistosomicides. Rev. Saude Publica, v. 12, p. 110, 1978.

DILLON, G. P.; FELTWELL, T.; SKELTON, J. P.; ASHTON, P. D.; COULSON, P. S.; QUAIL, M. A.; NIKOLAIDOU-KATSARIDOU, N.; WILSON, R. A.; IVENS, A. C. Microarray analysis identifies genes preferentially expressed in the lung schistosomulum of Schistosoma mansoni. Int. J. Parasitol., v. 36 , p. 1-8, 2006.

DOENHOFF, M. J.; KIMANI, G.; CIOLI, D. Praziquantel and the control of schistosomiasis. Parasitol. Today, v. 16, p. 364-366, 2000.

DOENHOFF, M.; CIOLI, D.; UTZINGER, J. Praziquantel: mechanisms of action, resistance and new derivatives for schistosomiasis. Curr. Opin. Chem. Biol., v. 21, p. 659-667, 2008.

DOENHOFF, M. J.; KUSEL, J. R.; COLES, G. C.; CIOLI, D. Resistance of Schistosoma mansoni to praziquantel: is there a problem? Trans R. Soc. Trop. Méd., v. 96, p. 465-469, 2002. 
DUBOIS, F.; CABY, S.; OGER, F.; COSSEAU, C. ; CAPRON, M.; GRUNAU, C.; DISSOUS, C.; PIERCE, R. J. Histone deacetylase inhibitors induce apoptosis, histone hyperacetylation and up-regulation of gene transcription in Schistosoma mansoni. Mol. Biochem. Parasitol., v. 168, p. 7-15, 2009.

DUPRÉ, HERV M.; SCHACHT, A. M.; CAPRON, A.; RIVEAU, G. Control of schistosomiasis pathology by combination of Sm28GST DNA immunization and praziquantel. J. Infect. Dis., v. 180, p. 454463, 1999.

DUPRÉ, L.; KREMER, L.; WOLOWCZUK, I.; RIVEAU, G.; CAPRON, A.; LOCHT, C. Immunostimulatory effect of IL-18-encoding plasmid in DNA vaccination against murine Schistosoma mansoni infection. Vaccine, v. 19, p. 1373-1380, 2001.

EISSA, M. M.; EL-AZZOUNI, M. Z.; AMER, E. I.; BADDOUR, N. M. Miltefosine, a promising novel agent for schistosomiasis mansoni. Int. J. Parasitol., v. 41, p. 235-242, 2011.

EKWALL, B.; SILANO, V.; PAGANUZZI-STAMMATI, A.; ZUCCO, F. Toxicity tests with mammalian cell cultures. In: BOURDEAU, P.; SOMMERS, E.; MARK RICHARDSON, G.; HICKMAN, J. R. Shortterm toxicity tests for non-genotoxic effects. Chichester, UK: Wiley, 1990, p. 75-97.

EL RIDI, R.; ABOUELDAHAB, M.; TALLIMA, H.; SALAH, M.; MAHANA, N.; FAWZI, S.; MOHAMED, S. H.; FAHMY, O. M. In vitro and in vivo activities of arachidonic acid against Schistosoma mansoni and Schistosoma haematobium. Antimicrob. Agents Chemother., v. 54, p. 3383-3389., 2010.

ERASMUS, D. A. A comparative study of the reproductive system of mature, immature and "unisexual" female Schistosoma mansoni. Parasitology, v. 67, p. 165-183, 1973.

ERASMUS, D. A. A. Structural and metabolic changes in female Schistosoma mansoni following male stimulation. J. Chem. Ecol., v. 12, p. 1755-1764, 1986.

ESTRELA, J. L. V.; GUEDES, R. N. C.; MALTHA, C. R. A.; FAZOLIN, M. Toxicidade de amidas análogas à piperina a larvas de Ascia monusteorseis Godart (Lepidoptera: Pieridae) e Spodoptera frugiperda (J. E. Smith) (Lepidoptera: Noctuidae). Neotrop. Entomol., v. 32, p. 343-346, 2003.

FAGHIRI, Z.; CAMARGO, S. M.; HUGGEL, K.; FORSTER, I. C.; NDEGWA, D.; VERREY, F.; SKELLY, $P$. J. The tegument of the human parasitic worm Schistosoma mansoni as an excretory organ: the surface aquaporin SmAQP is a lactate transporter. PLoS One, v. 5, p. e10451, 2010.

FALLON, P. G.; DOENHOFF, M. J. Drug-resistance schistosomiasis: resistance to praziquantel and oxamniquine induced in Schistosoma mansoni in mice is drug specific. Am. J. Trop. Med. Hyg., v. 51 , p. 83-88, 1994.

FENWICH, A.; SAVIOLI, L.; ENGELS, D.; BERGQUIST, R.; TODD, M. H. Drugs for the control of parasitic diseases: current status and development in schistosomiasis. Trends Parasitol., v. 19, p. 509-515, 2003.

FENWICH, A.; WEBSTER, J. P. Schistosomiasis: challenges for control, treatment, and drug resistance. Curr. Opin. Infect. Dis., v. 19, p. 577-582, 2006. 
FLEURY, Y.; VOUILLE, V.; BEVEN, L.; AMICHE, M.; WRÓBLEWSKI, H.; DELFOUR, A.; NICOLAS P. Synthesis, antimicrobial activity and gene structure of a novel member of the dermaseptin $B$ family. Biochim. Biophys. Acta, v. 1396, p. 228-236, 1998.

FONTENELE J. B.; LEAL, L. K.; SILVEIRA, E. R.; FELIX, F. H.; BEZERRA FELIPE, C. F.; VIANA, G. S. Antiplatelet effects of piplartine, an alkamide isolated from Piper tuberculatum: possible involvement of cyclooxygenase blockade and antioxidant activity. J. Pharm. Pharmacol., v. 61, p. 511-515, 2009.

FRANÇA, V. C.; VIEIRA, K. V. M.; LIMA, E. DE O.; BARBOSA-FILHO, J. M.; DA-CUNHA, E. V. L.; SILVA, M. S. Estudo fitoquímico das partes aéreas de Aristolochia birostris Ducht. (Aristolochiaceae). Rev. Bras. Farmacogn., v. 15, p. 326-330, 2005.

FREIRE-DE-LIMA, L.; RIBEIRO, T. S.; ROCHA, G. M.; BRANDÃO, B. A.; ROMEIRO, A.; MENDONÇAPREVIATO, L.; PREVIATO, J. O.; DE LIMA M. E.; DE CARVALHO, T. M.; HEISE, N. The toxic effects of piperine against Trypanosoma cruzi: ultrastructural alterations and reversible blockage of cytokinesis in epimastigote forms. Parasitol. Res., v. 102, p. 1059-1067, 2008.

GAZZinelLi, G.; DE OliVeirA, C. C.; FIGUeIREDO, E. A.; PEREIRA, L. H.; COELHO, P. M.; PELLEGRINO, J. Schistosoma mansoni: biochemical evidence for morphogenetic change from cercaria to schistosomule. Exp. Parasitol., v. 34, p. 181-188, 1973.

GOBERT, G. N.; CHAI, M.; MCMANUS, D. P. Biology of the schistosome lung-stage schistosomulum. Parasitology, v. 134, p. 453-460, 2007.

GOBERT, G. N.; TRAN, M. H.; MOERTEL, L.; MULVENNA, J.; JONES, M. K.; MCMANUS, D. P.; LOUKAS, A. Transcriptional changes in Schistosoma mansoni during early schistosomula development and in the presence of erythrocytes. PLoS Negl. Trop. Dis., v. 4, p. e600, 2010.

GRYSEELS, B.; MBAYE, A.; DE VLAS, S. J.; STELMA, F. F.; GUISSE, F. VAN LIESHOUT, L.; FAYE, D.; DIOP, M.; LY, A.; TCHUEM-TCHUENTE, L. A.; ENGLES, D.; POLMAN, K. Are poor responses to praziquantel for the treatment of Schistosoma mansoni infections in Senegal due to resistance? An overview of the evidence. Trop. Med. Int. Health, v. 6, p. 864-873, 2001.

GRYSEELS, B.; POLMAN, K.; CLERINX, J.; KESTENS, L. Human schistosomiasis. Lancet, v. 368, p. 1106-1118, 2006.

HAGAN, P.; APPLETON, C. C.; COLES, G. C.; KUSEL, J.R.; TCHUEM-TCHUENTÉ, L.A. Schistosomiasis control: keep taking the tablets. Trends Parasitol., v, 20, p. 92-7, 2004.

HARROP, R.; WILSON, R. A. Protein synthesis and release by cultured schistosomula of Schistosoma mansoni. Parasitology, v. 107, p. 265-274, 1993.

HOCKLEY, D. J. Ultrastructure of the tegument of Schistosoma. Adv. Parasitol., v. 11, p. 233$305,1973$.

HOCKLEY, D. J.; MCLAREN, D. J. Schistosoma mansoni: changes in the outer membrane of the tegument during development from cercaria to adult worm. Int. J. Parasitol., v. 3, p. 13-25, 1973. 
HOTEZ, P. J.; MOLYNEUX, D. H.; FENWICH, A.; KUMARESAN, J.; SACHS, S. E.; SACHS, J. D.; SAVIOLI, L. Control of neglected tropical diseases. N. Engl. J. Med., v. 357, p. 1018-1026, 2007.

HOTEZ, P. J.; ENGELS, D.; FENWICK, A.; SAVIOLI, L. Africa is desperate for praziquantel. Lancet. v. 376, p. $496-498,2010$.

HOWELLS, R. E.; RAMALHO-PINTO, F. J.; GAZZINELLI, G.; DE OLIVEIRA, C. C.; FIGUEIREDO, E. A.; PELLEGRINO, J. Schistosoma mansoni: mechanism of cercarial tail loss and its significance to host penetration. Exp. Parasitol., v. 36, p. 373-385, 1974.

HOWELLS, R. E.; GERKEN, S. E.; RAMALHO-PINTO, F. J.; KAWAZOE, U.; GAZZINELLI, G.; PELLEGRINO, J. Schistosoma mansoni: tail loss in relation to permeability changes during cercariaschistosomulum transformation. Parasitology, v. 71, p. 9-18, 1975.

HULSTIJN, M.; BARROS, L. A.; NEVES, R. H.; MOURA, E. G.; MACHADO-SILVA, J. R. Morphological changes in the reproductive organs of male and female Schistosoma mansoni worms caused by streptozotocin, a drug used to induce diabetes mellitus. Parasitology, v. 126, p. 53-61, 2003.

ISMAIL, M.; METWALLY, A.; FARGHALY, A.; BRUCE, J.; TAO, L. F.; BENNETT, J .L. Characterization of isolates of Schistosoma mansoni from Egyptian villagers that tolerate high doses of praziquantel. Am. J. Trop. Med. Hyg., v. 55, p. 214-218, 1996.

ISMAIL, M.; BOTROS, S.; METWALLY, A.; WILLIAM, S.; FARGHALLY, A.; TAO, L. F.; DAY, T. A.; BENNETT, J. L. Resistance to praziquantel: direct evidence from Schistosoma mansoni isolated from Egyptian villagers. Am. J. Trop. Med. Hyg., v. 60, p. 932-935, 1999.

ISOBE, T.; OHSAKI, A.; NAGATA, K. Antibacterial constituents against Helicobacter pylori of Brazilian medicinal plant, Pariparoba. Yakugaku Zasshi., v. 122, p. 291-294, 2002.

JARAMILLO, M. A.; MANOS, P. S. Phylogeny and patterns of floral diversity in the genus Piper (Piperaceae). Am. J. Bot., v. 88, p. 706-716, 2001.

KATO, M. J.; FURLAN, M. Chemistry and evolution of the Piperaceae. Pure Appl. Chem., v. 79, p. 529-538, 2007.

KATZ, N.; DIAS, E. P.; ARAÚJO, N.; SOUZA, C. P. Estudo de uma cepa humana de Schistosoma mansoni resistente a agentes esquistossomicidas. Rev. Soc. Bras. Med. Trop., v. 7, p. 381-387, 1973.

KATZ, N. Chemotherapy of schistosomiasis mansoni. Adv. Pharmacol. Chemother., v. 14, p. 170, 1977.

KATZ, N.; PEIXOTO, S. V. Análise crítica da estimativa do número de portadores de esquistossomose mansoni no Brasil. Rev. Soc. Bras. Med. Trop., v. 33, p. 303-308, 2000.

KATZ, N. Terapêutica experimental da esquistossomose mansoni. In: CARVALHO, O. S.; COELHO, P. M. Z.; LENZI, H. L. Schistosoma mansoni \& esquistossomose: uma visão interdisciplinar. Rio de Janeiro: FIOCRUZ, 2008. p. 823-847. 
KEISER, J. In vitro and in vivo trematode models for chemotherapeutic studies. Parasitology, v. 137, p. $589-603,2010$.

KEISER, J.; CHOLLET, J.; XIAO, S. H.; MEI, J. Y.; JIAO, P. Y.; UTZINGER, J.; TANNER, M. Mefloquine-an aminoalcohol with promising antischistosomal properties in mice. PLoS Negl. Trop. Dis., v. 3, p. e350, 2009.

KUMAR, A.; KHAN, I. A.; KOUL, S.; KOUL, J. L.; TANEJA, S. C.; ALI, I.; ALI, F.; SHARMA, S.; MIRZA, Z .M.; KUMAR, M.; SANGWAN, P. L.; GUPTA, P.; THOTA, N.; QAZI, G.N. Novel structural analogues of piperine as inhibitors of the NorA efflux pump of Staphylococcus aureus. J. Antimicrob. Chemother., v. 61, p. 1270-1276, 2008.

LAGO, J. H.; RAMOS, C. S.; CASANOVA, D. C.; MORANDIM, A. DE A.; BERGAMO, D. C.; CAVALHEIRO, A. J.; BOLZANI, V. DA S.; FURLAN, M.; GUIMARÃES, E. F.; YOUNG, M. C.; KATO, M. J. Benzoic acid derivatives from Piper species and their fungitoxic activity against Cladosporium cladosporioides and C. sphaerospermum. J. Nat. Prod., v. 67, p. 1783-1788, 2004.

LEITE, J. R.; BRAND, G. D.; SILVA, L. P.; KÜCKELHAUS, S. A.; BENTO, W. R.; ARAÚJO, A. L.; MARTINS, G. R.; LAZZARI, A. M.; BLOCH, C. Jr. Dermaseptins from Phyllomedusa oreades and Phyllomedusa distincta: Secondary structure, antimicrobial activity, and mammalian cell toxicity. Comp. Biochem. Physiol. A Mol. Integr. Physiol., v. 151, p. 336-343, 2008.

LEQUIN, O.; LADRAM, A.; CHABBERT, L. ; BRUSTON, F.; CONVERT, O.; VANHOYE, D.; CHASSAING, G.; NICOLAS, P.; AMICHE, M. Dermaseptin S9, an alpha-helical antimicrobial peptide with a hydrophobic core and cationic termini. Biochemistry, v. 45, p. 468-480, 2006.

LIANG, Y. S.; COLES, G. C.; DOENHOFF, M. J.; SOUTHGATE, V. R. In vitro responses of praziquantel-resistant and -susceptible Schistosoma mansoni to praziquantel. Int. J. Parasitol., v. 31, p. 1227-1235, 2001.

LOPES, N. P.; CHICARO, P.; KATO, M. J.; ALBUQUERQUE, S.; YOSHIDA, M. Flavonoids and lignans from Virola surinamensis twigs and their in vitro activity against Trypanosoma cruzi. Planta Med., v. 64, p. 667-668, 1998.

LORIN, C.; SAIDI, H.; BELAID, A.; ZAIRI, A.; BALEUX, F.; HOCINI, H.; BÉLEC, L.; HANI, K.; TANGY, F. The antimicrobial peptide dermaseptin S4 inhibits HIV-1 infectivity in vitro. Virology, v. 334, p. 264-75, 2005.

MACHADO-SILVA, J. R.; NEVES, R. H.; GOMES, D. C. Filogenia, co-evolução, aspectos morfológicos e biológicos das diferentes fases de desenvolvimento do Schistosoma mansoni. In: CARVALHO, O. S.; COELHO, P. M. Z.; LENZI, H. L. Schistosoma mansoni \& esquistossomose: uma visão interdisciplinar. Rio de Janeiro: FIOCRUZ, 2008. p. 43-84.

MAGALHÃES, L. G.; MACHADO, C. B.; MORAIS, E. R.; MOREIRA, E. B.; SOARES, C. S.; DA SILVA, S. H.; DA SILVA FILHO, A. A.; RODRIGUES, V. In vitro schistosomicidal activity of curcumin against Schistosoma mansoni adult worms. Parasitol. Res., v. 104, p. 1197-1201, 2009.

MAGALHÃES, L. G.; KAPADIA, G. J.; DA SILVA TONUCI, L. R.; CAIXETA, S. C. ; PARREIRA, N. A.; RODRIGUES, V.; DA SILVA FILHO, A. A. In vitro schistosomicidal effects of some phloroglucinol derivatives from Dryopteris species against Schistosoma mansoni adult worms. Parasitol. Res., 106, 395-401, 2010. 
MAIR, G. R.; MAULE, A. G.; SHAW, C.; HALTON, D. W. Muscling in on parasitic flatworms. Parasitol. Today, v. 14, p. 73-76, 1998.

MAIR, G. R.; MAULE, A. G.; DAY, T. A.; HALTON, D. W. A confocal microscopical study of the musculature of adult Schistosoma mansoni. Parasitology, v. 121, p. 163-170, 2000.

MANNECK, T.; HAGGENMÜLLER, Y.; KEISER, J. Morphological effects and tegumental alterations induced by mefloquine on schistosomula and adult flukes of Schistosoma mansoni. Parasitolology, v. 137, p. 85-98, 2010.

MARKS, N. J.; MAULE, A. G. Neuropeptides in helminths: occurrence and distribution. Adv. Exp. Med. Biol., v. 692, p. 49-77, 2010.

MARQUES, J. V.; OLIVEIRA, A.; RAGGI, L.; YOUNG, M. C. M.; KATO, M. J. Antifungal activity of natural and synthetic amides from Piper species. J. Braz. Chem. Soc., v. 21, p. 1807-1813, 2010.

MARTINS, R. C.; LATORRE, L. R.; SARTORELLI, P.; KATO, M. J. Phenylpropanoids and tetrahydrofuran lignans from Piper solmsianum. Phytochemistry, v. 55, p. 843-846, 2000.

MARTINS, R. C.; LAGO, J .H.; ALBUQUERQUE, S.; KATO, M. J. Trypanocidal tetrahydrofuran lignans from inflorescences of Piper solmsianum. Phytochemistry, v. 64, p. 667-670, 2003.

MCCLANE, B. A. Osmotic stabilizers differentially inhibit permeability alterations induced in Vero cells by Clostridium perfringens enterotoxin. Biochim. Biophys. Acta, v. 777, p. 99-106, 1984.

MCKERROW, J. H. Parasite proteases. Exp. Parasitol., v. 68, p. 111-115, 1989.

MCKERROW, J. H.; SALTER, J. Invasion of skin by Schistosoma cercariae. Trends Parasitol., v. 18, p. 193-195, 2002.

MCMANUS, D. P.; LOUKAS, A. Current status of vaccines for schistosomiasis. Clin. Microbiol. Rev., v. 21, p. 225-242, 2008.

MEHLHORN, H.; BECKER, B.; ANDREWS, P.; THOMAS, H.; FRENKEL, J. K. In vivo and in vitro experiments on the effects of praziquantel Schistosoma mansoni. Drug. Res., v. 31, p. 544-554, 1981.

MILLER, P.; WILSON, R. A. Migration of the schistosomula of Schistosoma mansoni from skin to lungs. Parasitology, v. 77, p. 281-302, 1978.

MITSUI, Y.; MIURA, M.; AOKI, Y. In vitro effects of artesunate on the survival of worm pairs and egg production of Schistosoma mansoni. J. Helminthol., v. 83, p. 7-11, 2009.

MIURA, L. M. C. V. Isolamento do alcalóide epiisopiloturina a partir da biomassa do jaborandi (Pilocarpus microphyllus) e avaliação de suas atividades antibacteriana, antileishmania, antiviral, antiesquistosoma e sialagoga. 2009. 123 f. Dissertação (Mestrado em Ciência Animal) - Pós-Graduação em Ciência Animal, Universidade Federal do Piauí, Teresina, 2009. 
MIURA L. M.; LIMA, D. F.; MORAES, J.; CARNEIRO, S. M.; BRAND, G. D. ; KAWANO, T.; CARVALHO, F. A.; BLOCH C. JR.; BATISTA, M. C. S.; LEITE, J. R. S. A. Evaluation of the in vitro activity of epiisopiloturin alkaloid isolated from jaborandi (Pilocarpus microphyllus Stapf ex Holm.; Rutaceae) against Schistosoma mansoni and Leishmania amazonensis. Acta Trop., 2010. In Press.

MOHAMED, A. M.; METWALLY, N. M.; MAHMOUD, S. S. Sativa seeds against Schistosoma mansoni different stages. Mem. Inst. Oswaldo Cruz, v. 100, p. 205-211, 2005.

MØLGAARD, P.; NIELSEN, S. B.; RASMUSSEN, D. E.; DRUMMOND, R. B.; MAKAZA, N.; ANDREASSEN, J. Anthelmintic screening of Zimbabwean plants traditionally used against schistosomiasis. J. Ethnopharmacol., v. 74, p. 257-264, 2001.

MOR, A.; HANI, K.; NICOLAS, P. The vertebrate peptide antibiotics dermaseptins have overlapping structural features but target specific microorganisms. J. Biol. Chem., v. 269, p. 31635-31641, 1994.

MORAES, J.; NASCIMENTO, C.; LOPES, P. O.; NAKANO, E.; YAMAGUCHI, L. F.; KATO, M. J.; KAWANO, T. Schistosoma mansoni: In vitro schistosomicidal activity of piplartine. Exp. Parasitol., v. 127, p. 357-364, 2011 a.

MORAES, J.; NASCIMENTO, C.; MIURA, L .M. C.; LEITE, J. R. S.; NAKANO, E.; KAWANO, T. Evaluation of the in vitro activity of dermaseptin 01 , cationic antimicrobial peptide, against Schistosoma mansoni. Chem. Biodivers., v. 8, p. 548-558, $2011 \mathrm{~b}$.

MORAES, J.; SILVA, M. P.; OHLWEILER, F. P.; KAWANO, T. Schistosoma mansoni and other larval trematodes in Biomphalaria tenagophila (Planorbidae) from Guarulhos, São Paulo State, Brazil. Rev. Inst. Med. Trop. Sao Paulo, v. 51, p. 77-82, 2009.

MORAND, S.; MÜLLER-GRAF, C. D. Muscles or testes? Comparative evidence for sexual competition among dioecious blood parasites (Schistosomatidae) of vertebrates. Parasitology, v. 120, p. 45$56,2000$.

MORANDiM, A. A.; PIN, A. R.; PIETRO, N. A. S.; ALECIO, A. C.; KATO, M. J.; YOUNG, C. M. ; DE OLIVEIRA, J. E. ; FURLAN, M. Composition and screening of antifungal activity against Cladosporium sphaerospermum and Cladosporium cladosporioides of essential oils of leaves and fruits of Piper species. Afr. J. Biotechnol., v. 9, p. 6135-6139, 2010.

MORGAN, J. A. T.; DEJONG, R. J.; SNYDER, S. D.; MKOJI, G. M.; LOKER, E. S. Schistosoma mansoni and Biomphalaria: past history and future trends. Parasitology, v. 123, p. S211-S228, 2001.

NAVICKIENE, H. M.; ALÉCIO, A. C.; KATO, M. J.; BOLZANI, V. D.; YOUNG, M. C.; CAVALHEIRO, A. J.; FURLAN, M. Antifungal amides from Piper hispidum and Piper tuberculatum. Phytochemistry, v. 55, p. $621-626,2000$.

NAVICKIENE, H. M.; BOLZANI, V. da S.; KATO, M. J.; PEREIRA, A. M.; BERTONI, B. W.; FRANÇA, S. C.; FURLAN, M. Quantitative determination of anti-fungal and insecticide amides in adult plants, plantlets and callus from Piper tuberculatum by reverse-phase high-performance liquid chromatography. Phytochem. Anal., v. 14, p. 281-284, 2003. 
NDAMBA, J.; NYAZEMA, N.; MAKAZA, N.; ANDERSON, C.; KAONDERA, K. C. Traditional herbal remedies used for the treatment of urinary schistosomiasis in Zimbabwe. J. Ethnopharmacol., v. 42 , p. $125-132,1994$.

NEVES, D. P. Parasitologia Humana. 11. ed. São Paulo: Atheneu, 2005.

NEVES, J. K.; BOTELHO, S. P.; DE MELO, C. M.; PEREIRA, V. R.; DE LIMA, M. DO C.; PITTA IDA R.; ALBUQUERQUE, M. C.; GALDINO, S. L. Biological and immunological activity of new imidazolidines against adult worms of Schistosoma mansoni. Parasitol. Res., v. 107, p. 531-538, 2010.

NOËL, F. Sistema neuromuscular e controle da motilidade no verme adulto. In: CARVALHO, O. S.; COELHO, P. M. Z.; LENZI, H. L. Schistosoma mansoni \& esquistossomose: uma visão interdisciplinar. Rio de Janeiro: FIOCRUZ, 2008. p. 207-244.

NOGUeIRA, C. D.; DE MELlO, R. P.; KATO, M. J.; CABRAL, M. M. Disruption of Chrysomya megacephala growth caused by lignan grandisin. J. Med. Entomol.. v. 46, p. 281-283, 2009.

PARAENSE, W. L. The schistosome vectors in Americas. Mem. Inst. Oswaldo Cruz, v. 96, p. 716, 2001. Suppl.

PARREIRA, N. A.; MAGALHÃES, L. G.; MORAIS, D. R.; CAIXETA, S. C.; DE SOUSA, J. P.; BASTOS, J. K.; CUNHA, W. R.; SILVA, M. L.; NANAYAKKARA, N. P.; RODRIGUES, V.; da SILVA FILHO, A. A. Antiprotozoal, schistosomicidal, and antimicrobial activities of the essential oil from the leaves of Baccharis dracunculifolia. Chem. Biodivers., v. p. 993-1001, 2010.

PARMAR, V. S.; JAIN, S. C.; BISHT, K. S.; JAIN, R., TANEJA, P.; JHA, A.; TYAGI, O. M.; PRASAD, A. K.; WENGEL, J.; OLSEN, C. E.; BOLL, P. M. Phytochemistry of the genus Piper. Phytochemistry, v. 46, p. 597-673, 1997.

PAX, R. A.; BENNETT, J. L. Neurobiology of parasitic platyhelminths: possible solutions to the problems of correlating structure with function. Parasitology, v. 102, p. S31-S39, 1991. Suppl.

PAX, R .A.; DAY, T. A.; MILLER, C. L.; BENNETT, J. L. Neuromuscular physiology and pharmacology of parasitic flatworms. Parasitology, v. 113, p. S83-S96, 1996. Suppl.

PAYARES, G.; MCLAREN, D. J.; EVANS, W. H.; SMITHERS, S. R. Changes in the surface antigen profile of Schistosoma mansoni during maturation from cercaria to adult worm. Parasitology, $v$. 91, p. 83-99, 1985.

PEARCE, E. J.; SHER, A. Mechanisms of immune evasion in schistosomiasis. Contrib. Microbiol. Immunol., v. 8, p. 219-32, 1987.

PELLEGRINO, J.; OLIVEIRA, C. A.; FARIA, J.; CUNHA, A. S. New approach to the screening of drugs in experimental schistosomiasis mansoni in mice. Am. J. Trop. Med. Hyg., v. 11, p. 201-215, 1962.

PELlEgRINO, J.; KATZ, N. Experimental chemotherapy of schistosomiasis mansoni. Adv. Parasitol., v. 6, p. 233-290, 1968. 
PICA-MATTOCIA, L.; CIOLI, D. Sex- and stage-related sensitivity of Schistosoma mansoni to in vivo and in vitro praziquantel treatment. Int. J. Parasitol., v. 34, p. 527-533, 2004.

PINHEIRO, C. U. B. Jaborandi (Pilocarpus sp., Rutaceae): A wild species and its rapid transformation into a crop. Econ. Bot., v. 51, p. 49-58, 1997.

PRADEEP, C. R.; KUTTAN, G. Effect of piperine on the inhibition of lung metastasis induced B16F10 melanoma cells in mice. Clin. Exp. Metastasis, v. 19, p. 703-708, 2002.

PRASAD, A. K.; KUMAR, V.; ARYA, P.; KUMAR, S.; DABUR, R.; SINGH, N.; CHHILLAR, A. K.; SHARMA, G.; GHOSH, B.; WENGEL, J.; OLSEN, C. E.; PARMAR, V. S. Investigations toward new lead compounds from medicinally important plants. Pure Appl. Chem., v. 77, p. 25-40, 2005.

RAAY, B.; MEDDA, S.; MUKHOPADHYAY, S.; BASU, M. K. Targeting of piperine intercalated in mannose-coated liposomes in experimental leishmaniasis. Indian J. Biochem. Biophys., v. 36, p. 248-251, 1999.

RACE, G. J.; MARTIN, J. H.; MOORE, D. V.; LARSH, J. E. Jr. Scanning and transmission electronmicroscopy of Schistosoma mansoni eggs, cercariae, and adults. Am. J. Trop. Med. Hyg., v. 20 , p. $914-924,1971$.

RAMALHO-PINTO, F. J.; GAZZINELLI, G.; HOWELLS, R. E.; MOTA-SANTOS, T. A.; FIGUEIREDO, E. A.; PELLEGRINO, J. Schistosoma mansoni: defined system for stepwise transformation of cercaria to schistosomule in vitro. Exp. Parasitol., v. 36, p. 360-372, 1974.

RAMALHO-PINTO, F. J.; GAZZINELLI, G.; HOWELLS, R. E.; PELLEGRINO, J. Factors affecting surface changes in intact cercariae and cercarial bodies of Schistosoma mansoni. Parasitology, v. 71, p. 19-25, 1975.

RAMIREZ, B.; BICKLE, Q.; YOUSIF, F.; FAKOREDE, F.; MOURIES, M. A.; NWAKA, S. Schistosomes: Challenges in drug screening. Exp. Opin. Drug Discov., v. 2, p. 53-61, 2007.

RAPADO, L. N.; NAKANO, E.; OHLWEILER, F. P.; KATO, M. J.; YAMAGUCHI, L. F.; PEREIRA, C. A.; KAWANO, T. Molluscicidal and ovicidal activities of plant extracts of the Piperaceae on Biomphalaria glabrata (Say, 1818). J. Helminthol., v. 6, p. 1-7, 2010.

REGASINI, L. O.; COTINGUIBA, F.; PASSERINI, G. D.; BOLZANI, V. DA S.; CICARELLI, R.M.B.; KATO, M. J.; FURLAN, M. Trypanocidal activity of Piper arboreum and Piper tuberculatum (Piperaceae). Rev. Bras. Farmacogn., v. 19, p. 199-203, 2009.

REMME, J, H.; BLAS, E.; CHITSULO, L.; DESJEUX, P. M.; ENGERS, H. D.; KANYOK, T. P.; KAYONDO, J. F.; KIOY, D. W.; KUMARASWAMI, V.; LAZDINS, J. K.; NUNN, P. P.; ODUOLA, A.; RIDLEY, R. G.; TOURE, Y. T.; ZICKER, F.; MOREL, C. M. Strategic emphases for tropical diseases research: a TDR perspective. Trends Microbiol., v. 10, p. 435-440, 2002.

REY, L. Parasitologia: parasitos e doenças parasitárias do homem nos trópicos ocidentais. 4. ed. Rio de Janeiro: Guanabara Koogan, 2008.

RIBEIRO, T. S.; FREIRE-DE-LIMA, L.; PREVIATO, J. O.; MENDONÇA-PREVIATO, L.; HEISE, N.; DE LIMA, M. E. Toxic effects of natural piperine and its derivatives on epimastigotes and amastigotes of Trypanosoma cruzi. Bioorg. Med. Chem. Lett., v. 14, p. 3555-3558, 2004. 
ROGERS, S. H.; BUEDING, E. Hycanthone resistance: development in Schistosoma mansoni. Science. v. 172, p. 1057-1058, 1971.

ROSS A. G.; BARTLEY, P. B.; SLEIGH, A. C.; OLDS G. R.; LI, Y.; WILLIAMS, G. M.; MCMANUS, D. P. Schistosomiasis. N. Engl. J. Med., v. 346, p. 1212-1220, 2002.

SAAD, J. M.; SOEPADAMO, E.; FANG, X. P.; MCLAUGHLIN, J. L.; FANWICK, P. E. (-)-Grandisin form Cryptocarya crassinervia. J. Nat. Prod., v. 54, p. 1681-1683, 1991.

SABAH, A. A.; FLETCHER, C.; WEBBE, G.; DOENHOFF, M. J. Schistosoma mansoni: chemotherapy of infections of different ages. Exp. Parasitol., v. 61, p. 294-303, 1986.

SANDERSON, L.; BARTLETT, A.; WHITFIELD, P. J. In vitro and in vivo studies on the bioactivity of a ginger (Zingiber officinale) extract towards adult schistosomes and their egg production. $\mathbf{J}$. Helminthol., v. 76, p. 241-247, 2002.

SANGSTER, N. C.; SONG, J.; DEMELER, J. Resistance as a tool for discovering and understanding targets in parasite neuromusculature. Parasitology, v. 131, p. S179-S190, 2005. Suppl.

SANTOS, A. P.; MORENO, P. R. H. Pilocarpus spp.: A survey of its chemical constituents and biological activities. Rev. Bras. Cienc. Farm., v. 40. p. 115-137, 2004.

SAYED, A. A.; SIMEONOV. A.; THOMAS, C. J.; INGLESE, J.; AUSTIN, C. P.; WILLIAMS, D. L. Identification of oxadiazoles as new drug leads for the control of schistosomiasis. Nat. Med., v. 14, p. 407-412, 2008.

SCHELL, S. C. How to know the trematodes. Dubuque: WMC Brown, 1970.

SCOTT, I. M.; PUNIANI, E.; DURST, T.; PHELPS, D.; MERALI, S.; ASSABGUI, R. A.; SÁNCHEZVINDAS, P.; POVEDA, L.; PHILOGÈNE, B. J. R.; ARNASON, J. T. Insecticidal activity of Piper tuberculatum Jacq. extracts: synergistic interaction of piperamides. Agr. Forest. Entomol., v. 4, p. $137-144,2002$.

SCOTT, I. M.; JENSEN, H.; NICOL, R.; LESAGE, L.; BRADBURY, R.; SÁNCHEZ-VINDAS, P.; POVEDA, L.; ARNASON, J. T.; PHILOGĖNE, B. J. R. Efficacy of Piper (Piperaceae) extracts for control of common home and garden insect pests. J. Econ. Entomol., v. 97, p. 1390-1403, 2004.

SECOR, W. E. Interactions between schistosomiasis and infection with HIV-1. Parasite Imunol., v. 28 , p. 597-603, 2006.

SHARMA, S.; KUMAR, M.; SHARMA, S.; NARGOTRA, A.; KOUL, S.; KHAN, I. A. Piperine as an inhibitor of Rv1258c, a putative multidrug efflux pump of Mycobacterium tuberculosis. $J$. Antimicrob. Chemother., v. 65, p. 1694-701, 2010.

SHUHUA, X.; BINGgUI, S.; CHOLLET, J.; TANNER, M. Tegumental changes in adult Schistosoma mansoni harbored in mice treated with praziquantel enantiomers. Acta Trop., v. 76, p. 107-117, 2000a. 
SHUHUA, X.; CHOLLET, J.; WEISS, N. A.; BERGQUIST, R. N.; TANNER, M. Preventive effect of artemether in experimental animals infected with Schistosoma mansoni. Parasitol. Int., v. 49, p. 19-24, 2000b.

SILVA, L. J. Crescimento urbano e doença: A esquistossomose no município de São Paulo (Brasil). Rev. Saude Públ., v. 19, p. 1-7, 1985.

SIMAS. N. K.; LIMA, E. D. A. C.; KUSTER, R. M.; LAGE, C. L. ; DE OLIVEIRA FILHO, A. M. Potential use of Piper nigrum ethanol extract against pyrethroid-resistant Aedes aegypti larvae. Rev. Soc. Bras. Med. Trop., v. 40, p. 405-407, 2007.

SKELLY, P. J.; ALAN WILSON, R. Making sense of the schistosome surface. Adv. Parasitol., v. 63, p. $185-284,2006$

SKELLY, P. J.; SHOEMAKER, C. B. Induction cues for tegument formation during the transformation of Schistosoma mansoni cercariae. Int. J. Parasitol., v. 30, p. 625-631, 2000.

SMITHERS, S. R.; TERRY, R. J. The infection of laboratory hosts with cercariae of Schistosoma mansoni and the recovery of the adult worms. Parasitology, v. 55, p. 695-700, 1965.

SPARG, S. G.; Van STANDEN, J., JAGER, A. K. Efficiency of traditionally used South African plants against schistosomiasis. J. Ethnopharmacol., v. 73, v. 1-2, p. 209-214, 2000.

STEINAUER, M. L. The sex lives of parasites: investigating the mating system and mechanisms of sexual selection of the human pathogen Schistosoma mansoni. Int. J. Parasitol., v. 39, p. 1157$1163,2009$.

STEINMANN, P.; KEISER, J.; BOS, R.; TANNER, M.; UTZINGER, J. Schistosomiasis and water resources development: systematic review, meta-analysis, and estimates of people at risk. Lancet Infect. Dis., v. 6, p. 411-425, 2006.

STIREWAlT, M. A. Schistosoma mansoni: cercaria to schistosomule. Adv. Parasitol., v. 12, p. 115-182, 1974.

SUNILA, E. S.; KUTTAN, G. Immunomodulatory and antitumor activity of Piper longum Linn. and piperine. J. Ethnopharmacol., v. 90, p. 339-346, 2004.

TALLIMA, H.; EL RIDI, R. Schistosoma mansoni glyceraldehyde 3-phosphate dehydrogenase is a lung-stage schistosomula surface membrane antigen. Folia Parasitol., v. 55, p. 180-186, 2008.

TAMAN. A.; RIBEIRO, P. Investigation of a dopamine receptor in Schistosoma mansoni: functional studies and immunolocalization. Mol. Biochem. Parasitol., v. 168, p. 24-33, 2009.

TAMAN. A.; RIBEIRO, P. Glutamate-mediated signaling in Schistosoma mansoni: a novel glutamate receptor is expressed in neurons and the female reproductive tract. Mol. Biochem. Parasitol., v. 176, p. 42-50, 2011.

TCHUEM TCHUENTÉ, L. A.; SOUTHGATE, V. R.; COMBES, C.; JOURDANE, J. Mating behaviour in schistosomes: are paired worms always faithful? Parasitol. Today, v. 12, p. 231-236, 1996. 
TELES, H. M. S.; CARVALHO, O. S. Implicações da biologia de Biomphalaria no controle da esquistossomose. In: CARVALHO, O. S.; COELHO, P. M. Z.; LENZI, H. L. Schistosoma mansoni \& esquistossomose: uma visão interdisciplinar. Rio de Janeiro: FIOCRUZ, 2008. p. 459-484.

TROUILLER, P.; OLLIARO, P.; TORREELE, E.; ORBINSKI, J.; LAING, R.; FORD, N. Drug development for neglected diseases: a deficient market and a public-health policy failure. Lancet. v. 359, p. 2188-2194, 2002.

UTZINGER, J.; XIAO, S.; N'GORAN, E. K.; BERGQUIST, R.; TANNER, M. The potential of artemether for the control of schistosomiasis. Int. J. Parasitol., v. 31, p. 1549-1562, 2001 a.

UTZINGER, J.; XIAO, S.; KEISER, J.; CHEN, M.; ZHENG, J.; TANNER, M. Current progress in the development and use of artemether for chemoprophylaxis of major human schistosome parasites. Curr. Med. Chem., v. 8, p. 1841-1860, 2001b.

UTZINGER, J.; KEISER, J.; SHUHUA, X.; TANNER, M.; SINGER, B. H. Combination chemotherapy of schistosomiasis in laboratory studies and clinical trials. Antimicrob. Agents Chemother., v. 47, p. 1487-1495, 2003.

Van HELLEMOND, J. J.; RETRA, K.; BROUWERS, J. F.; Van BALKOM, B. W.; YAZDANBAKHSH, M.;SHOEMAKER, C. B.; TIELENS, A. G. Functions of the tegument of schistosomes: clues from the proteome and lipidome. Int. J. Parasitol., v. 36, p. 691-699, 2006.

Van NASSAUW, L.; TOOVEY, S.; Van OP DEN BOSCH, J.; TIMMERMANS, J. P.; VERCRUYSSE, J. Schistosomicidal activity of the antimalarial drug, mefloquine, in Schistosoma mansoni-infected mice. Travel Med. Infect. Dis., v. 6, p. 253-258, 2008.

VASQUES DA SILVA, R.; NAVICKIENE, H. M.; KATO, M. J. ; BOLZANI, V. da S.; MÉDA, C. I.; YOUNG, M. C.; FURLAN, M. Antifungal amides from Piper arboreum and Piper tuberculatum. Phytochemistry, v. 59, p. 521-527, 2002.

VEERAREDDY, P. R.; VOBALABOINA, V.; NAHID, A. Formulation and evaluation of oil-in-water emulsions of piperine in visceral leishmaniasis. Pharmazie, v. 59, p. 194-197, 2004.

WILLIAM, S., BOTROS, S., ISMAIL, M., FARGHALLY, A., DAY, T. A., BENNETT, J. L. Praziquantelinduced tegumental damage in vitro is diminished in schistosomes derived from praziquantelresistant infections. Parasitology, v. 122, p. 63-66, 2001.

WILSON, R. A.; DRASKAU, T.; MILLER, P.; LAWSON, J. R. Schistosoma mansoni: the activity and development of the schistosomulum during migration from the skin to the hepatic portal system. Parasitology, v. 77, p. 57-73, 1978.

WILSON, R. A.; COULSON, P. S. Schistosoma mansoni: dynamics of migration through the vascular system of the mouse. Parasitology, v. 92, p. 83-100, 1986.

WILSON, R. A.; COULSON, P. S; DIXON, B. Migration of the schistosomula of Schistosoma mansoni in mice vaccinated with radiation-attenuated cercariae, and normal mice: an attempt to identify the timing and site of parasite death. Parasitology, v. 92, p. 101-116, 1986. 
WILSON, R. A.; COULSON, P. S; STURROCK, R. F.; REID, G. D. Schistosome migration in primates: a study in the olive baboon (Papio anubis). Trans. R. Soc. Trop. Med. Hyg., v. 84, p. 80-83, 1990.

WILSON, R. A. The saga of schistosome migration and attrition. Parasitology, v. 136, p. 1581$1592,2009$.

WILSON, M. S.; MENTINK-KANE, M. M.; PESCE, J. T.; RAMALINGAM, T. R.; THOMPSON, R.; WYNN, T. A. Immunopathology of schistosomiasis. Immunol. Cell Biol., v. 85, p. 148-154, 2007.

WORLD HEALTH ORGANIZATION. The control of schistosomiasis. Tech. Rep. Ser., v. 728, p. 1$113,1985$.

WORLD HEALTH ORGANIZATION. The control of Schistosomiasis: second report of the WHO Expert Committee. Geneva: WHO, 1993.

WORLD HEALTH ORGANIZATION. Report of the WHO informal Consulation on Schistosomiasis Control. Geneva: WHO, 1999.

WORLD HEALTH ORGANIZATION. Prevention and control of schistosomiasis and soiltrasnmitted helminthiasis. Techinical Report Series 912. Geneva: WHO, 2002.

WORLD HEALTH ORGANIZATION. Preventive chemotherapy in human helminthiasis: coordinated use of anthelminthic drugs in control interventions. Geneva: WHO, 2006.

WORLD HEALTH ORGANIZATION. Partners for parasite control: Prevention and control of schistosomiasis and soil-transmitted helminthiasis", Available from: <http://www.who.int/wormcontrol/documents/ joint_statements/en/ppc_unicef_finalreport.pdf>. Acesso em 20 jan. 2011.

WORLD HEALTH ORGANIZATION. The global atlas on schistosomiasis. Avaliable from: www.who.int/schistosomiasis/epidemiology. Acesso em 20 jan. 2011.

WYNN, T. A.; THOMPSON, R. W.; CHEEVER, A. W.; MENTINK-KANE, M. M. Immunopathogenesis of schistosomiasis. Immunol. Rev., v. 201, p. 156-167, 2004.

XAVIER, A. M.; MAGALHÃES, J. A.; CUNHA, G. DOS S.; SILVA, A. C.; TAVARES, D. A.; SARROSILVA, M. DE F.; DE MORAES NETO, A. H. Morphological tegument alterations of adult Schistosoma mansoni, harbored in non anti-helminthic treated, high-immune-tolerogenic and low-inflammatory mice. Acta Trop., v. 116, p. 95-99, 2010.

XIAO, S. H.; CATTO, B. A. In vitro and in vivo studies of the effect of artemether on Schistosoma mansoni. Antimicrob. Agents Chemother., v. 33, p. 1557-1562, 1989.

XIAO, S. H.; CATTO, B. A.; WEBSTER Jr., L.T. Effects of praziquantel on different developmental stages of Schistosoma mansoni in vitro and in vivo. J. Infect. Dis., v. 151, p. 1130-1137, 1985.

XIAO, S.; BINGGUI, S.; CHOLLET, J.; TANNER, M. Tegumental changes in 21-day-old Schistosoma mansoni harboured in mice treated with artemether. Acta Trop., v. 75, p. 341-348, 2000 a. 
XIAO, S.; SHEN, B.; CHOLLET, J.; UTZINGER, J.; TANNER, M. Tegumental changes in adult Schistosoma mansoni harbored in mice treated with artemether. J. Parasitol., v. 86, p. 1125$1132,2000 b$.

XIAO, S.; TANNER, M.; N'GORAN, E. K.; UTZINGER, J.; CHOLLET, J.; BERGQUIST, R.; CHEN, M.; ZHENG, J. Recent investigations of artemether, a novel agent for the prevention of schistosomiasis japonica, mansoni and haematobia. Acta Trop., v. 82, p. 175-181, 2002.

XIAO, S. H.; KEISER, J.; CHOLLET, J.; UTZINGER, J.; DONG, Y.; ENDRISS, Y.; VENNERSTROM, J. L.; TANNER, M. In vitro and in vivo activities of synthetic trioxolanes against major human schistosome species. Antimicrob. Agents Chemother., v. 51, p. 1440-1445, 2007.

XIAO, S. H.; MEI, J. Y.; JIAO, P. Y. The in vitro effect of mefloquine and praziquantel against juvenile and adult Schistosoma japonicum. Parasitol. Res., v. 106, p. 237-246, 2009.

YANG, W.; JACKSON, D. C.; ZENG, Q.; MCMANUS, D. P. Multi-epitope schistosome vaccine candidates tested for protective immunogenicity in mice. Vaccine, v. 19, p. 103-113, 2000.

YOSRY, A. Schistosomiasis and neoplasia. Contrib. Microbiol., v. 13, p. 81-100, 2006.

ZAMPA, M. F.; ARAÚJO, I. M.; COSTA, V.; NERY COSTA, C. H.; SANTOS, J. R. JR.; ZUCOLOTTO, V.; EIRAS, C.; LEITE, J. R. Leishmanicidal activity and immobilization of dermaseptin 01 antimicrobial peptides in ultrathin films for nanomedicine applications. Nanomedicine, v. 5, p. 352-358, 2009.

ZHANG, H. J.; TAMEZ, P. A.; VU, D. H.; GHEE, T. T.; NGUYEN, V. H.; LE, T. X. ; LE, M. H.; NGUYEN, M. C.; DO, T. T.; SOEJARTO, D. D.; FONG, H. H. Antimalarial compounds from Rhaphidophora decursiva. J. Nat. Prod., v. 64, p. 772-777, 2001.

ZHANG, Y.; MACARTHUR, C.; MUBILA, L.; BAKER, S. Control of neglected tropical diseases needs a long-term commitment. BMC Med., v. 8, p. 67, 2010. 
ANEXOS 


\section{ANEXO - A \\ Schistosoma mansoni: In vitro schistosomicidal activity of piplartine}




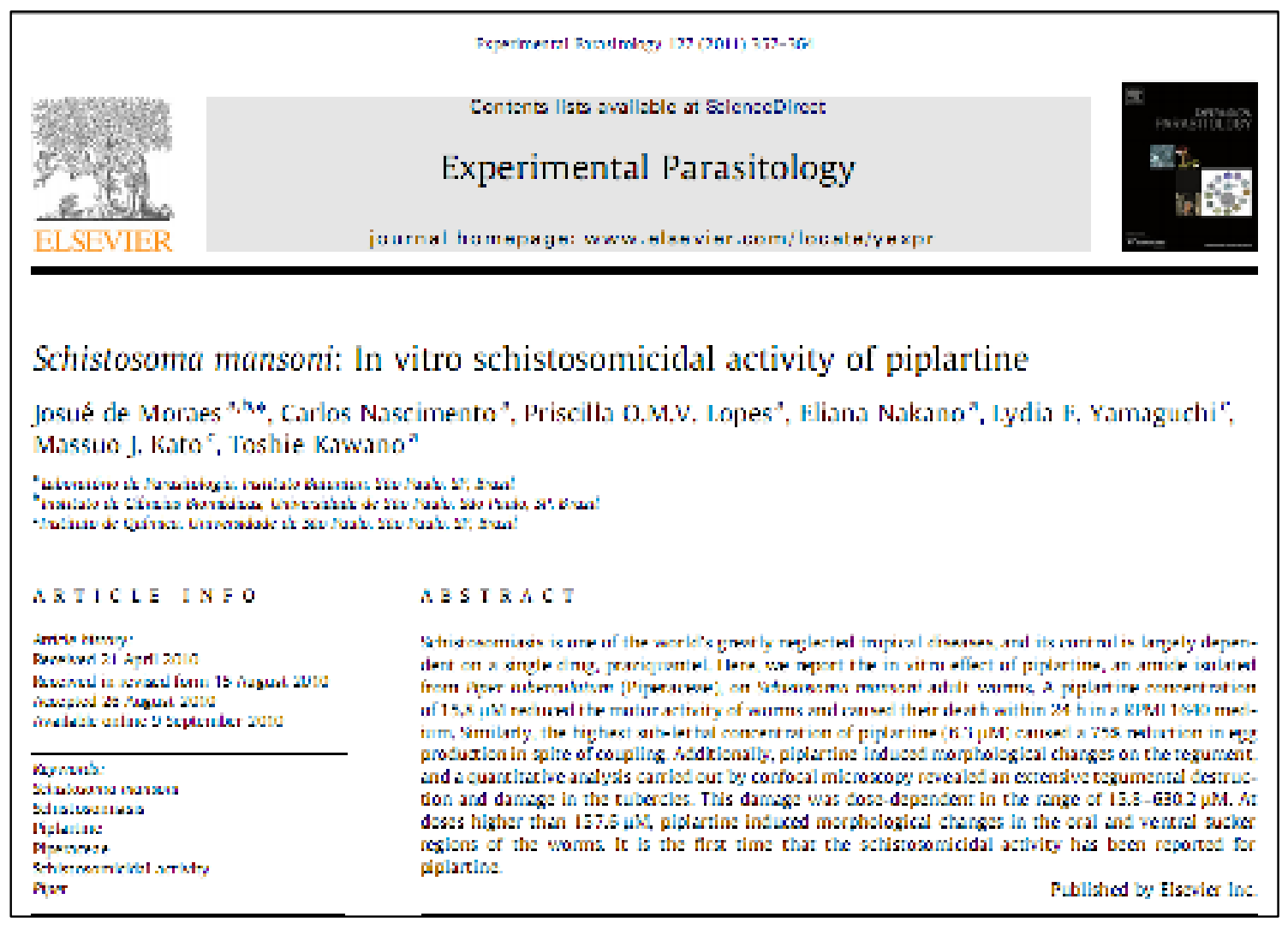

\section{Schistosoma mansoni: In vitro schistosomicidal activity of piplartine}

Josué de Moraes $^{1,2 *}$, Carlos Nascimento ${ }^{1}$, Priscilla O.M.V. Lopes ${ }^{1}$, Eliana Nakano ${ }^{1}$, Lydia F. Yamaguchi $^{3}$, Massuo J. Kato ${ }^{3}$, Toshie Kawano ${ }^{1}$

${ }^{1}$ Laboratório de Parasitologia, Instituto Butantan, São Paulo, SP, Brazil.

${ }^{2}$ Instituto de Ciências Biomédicas, Universidade de São Paulo, São Paulo, SP, Brazil.

${ }^{3}$ Instituto de Química, Universidade de São Paulo, São Paulo, SP, Brazil.

*Corresponding author: Laboratório de Parasitologia, Instituto Butantan, Avenida Vital Brasil 1500, CEP 05503-900, São Paulo, SP, Brazil. Fax: +55 11 3726-1505. Tel: +55 11 3726-7222

R. 2281/2158. E-mail: josuem@usp.br. 


\begin{abstract}
Schistosomiasis is one of the world's greatly neglected tropical diseases, and its control is largely dependent on a single drug, praziquantel. Here, we report the in vitro effect of piplartine, an amide isolated from Piper tuberculatum (Piperaceae), on Schistosoma mansoni adult worms. A piplartine concentration of $15.8 \mu \mathrm{M}$ reduced the motor activity of worms and caused their death within $24 \mathrm{~h}$ in a RPMI 1640 medium. Similarly, the highest sub-lethal concentration of piplartine $(6.3 \mu \mathrm{M})$ caused a $75 \%$ reduction in egg production in spite of coupling. Additionally, piplartine induced morphological changes on the tegument, and a quantitative analysis carried out by confocal microscopy revealed an extensive tegumental destruction and damage in the tubercles. This damage was dose-dependent in the range of 15.8 to $630.2 \mu \mathrm{M}$. At doses higher than $157.6 \mu \mathrm{M}$, piplartine induced morphological changes in the oral and ventral sucker regions of the worms. It is the first time that the schistosomicidal activity has been reported for piplartine.
\end{abstract}

Keywords: Schistosoma mansoni, schistosomiasis, piplartine, Piperaceae, schistosomicidal activity, Piper.

\title{
1. Introduction
}

Schistosomiasis is one of the most prevalent, debilitating and neglected disease of tropical and subtropical regions, such as Africa, Asia and South America. This parasitic disease ranks second after malaria in terms of its public health importance, and it is estimated that more than 207 million people have been infected worldwide, while 779 million people remain under infection risk (Steinmann et al., 2006). Schistosoma mansoni is one of the most common etiological agents of human schistosomiasis, and the disease pathology is, typically, 
a consequence of the inflammatory granulomatous reaction due to the deposition of parasite eggs in the liver and other host tissues (Gryseels et al., 2006).

The current treatment is based on the use of praziquantel (PZQ), a non-expensive anthelminthic drug that is highly effective against all schistosome species infecting humans. Since PZQ is generally well-tolerated, its use in mass treatment approaches is quite suitable (Hagan et al., 2004). However, any parasite treatment based on the use of a single drug poses serious concerns regarding the onset of resistance. Therefore, the development of novel and effective schistosomicidal compounds is highly desirable (Caffrey, 2007; Doenhoff et al., 2008). In this context, the search for bioactive natural products against schistosome has great importance for establishing future strategies to control schistosomiasis (Ndamba et al., 1994; Mølgaard et al., 2001; Sanderson et al., 2002; Mohamed et al., 2005).

The genus Piper (Piperaceae) includes species that are widely distributed throughout the tropical and subtropical regions of the world (Jaramillo and Manos, 2001). Some of these species are especially important in the traditional medicine of China, India, Southwestern Asia and Latin America. They are used to treat numerous ailments including chronic respiratory diseases, chest pain, hemorrhoids, rheumatism, gastrointestinal disorders, and venereal diseases. Anxiolytic, vasodilator, anesthetic, analgesic, and anti-inflammatory properties of Piper species have also been described (for reviews see Parmar et al., 1997; Prasad et al., 2005). Moreover, Piperaceae species have been extensively investigated as a source of new natural products with potential antitumoral, antimicrobial, antifungal, and insecticidal activities. Likewise, chemical studies have revealed the occurrence of several biologically active metabolites such as pyrones, terpenes, lactones, chromenes, chalcones, lignoids, amides, and alkaloids (for reviews see Parmar et al., 1997; Kato and Furlan, 2007).

Piplartine, 5,6-dihydro-1-[1-oxo-3-(3,4,5-trimethoxyphenyl)-2-propenyl]-2(1H)pyridinone, is an amide found in several Piper species such as $P$. tuberculatum (Navickiene et 
al., 2000). This amide has shown several biological activities such as anxiolytic and antidepressant (Cícero Bezerra Felipe et al., 2007) as well antifungal and insecticide (Navickiene et al., 2000, 2003; Vasques da Silva et al., 2002). In addition, piplartine has shown potential activity against protozoan species that cause other neglected tropical diseases. For instance, a piplartine treatment displayed significant in vitro antileishmanial activity against Leishmania donovani, and it reduced the parasitic burden and spleen weight in vivo using a hamster model of visceral leishmaniasis (Bodiwala et al., 2007). Similarly, piplartine also showed in vitro trypanocidal activity against epimastigote forms of Trypanosoma cruzi (Cotinguiba et al., 2009). Here, we investigated the effect of the piplartine amide isolated from $P$. tuberculatum against the adult worms of $S$. mansoni. The efficacy of this amide was examined regarding: a) schistosome survival; b) reproductive fitness; c) motor activity; and d) alterations on $S$. mansoni tegumental surface examined through confocal microscopy.

\section{Material and methods}

\subsection{Plant material}

The plant material was collected in September of 2005 from a specimen of Piper tuberculatum growing under greenhouse conditions at the Institute of Chemistry (University of São Paulo-SP, Brazil), and it was identified by Dr. Guillermo E. D. Paredes (Universidad Pedro Ruiz Gallo, Lambayeque, Peru). The voucher specimen (Kato-163) was deposited at the Herbarium of the Institute of Biosciences of the University of São Paulo (IB-USP), São Paulo, Brazil.

\subsection{Extraction and isolation of piplartine}

A dry powder was extracted with $\mathrm{MeOH}(2 \times 21)$ at room temperature over three days from inflorescences of $P$. tuberculatum (500 g). The solutions were filtered and concentrated 
under vacuum conditions, yielding dark syrup (47 g). Part of this extract $(2 \mathrm{~g})$ was submitted to a silica chromatography column using a gradient of hexane-EtOAc at increasing polarities, which yielded 35 fractions. Fraction 20 (350 mg) was re-crystallized with hot $\mathrm{MeOH}$; a white crystalline compound was obtained $\left(150 \mathrm{mg}\right.$ ) and was identified as piplartine (Fig. 1) by ${ }^{1} \mathrm{H}$ NMR analysis according to published data (Navieckiene et al., 2000).

\subsection{Parasite}

Schistosoma mansoni (BH strain Belo Horizonte, Brazil) worms have been maintained in Biomphalaria glabrata snails and Mesocricetus auratus hamsters hosts at the Parasitology Laboratory (Instituto Butantan, São Paulo, Brazil). Female hamsters, weighting 20 to 22 g, were infected by subcutaneous injection of 150 cercariae. After 7 weeks, adults $S$. mansoni specimens were recovered from the hamster by perfusion with RPMI 1640 medium supplemented with heparin (Smithers and Terry, 1965).

\subsection{Ethics statement}

This study was approved by the Institutional Review Board of the Instituto Butantan (approval number: 415/07). All animals were handled in strict accordance with good animal practice as defined by the Animals Use Ethics Committee of the University of São Paulo (USP, São Paulo, Brazil) and the Instituto Butantan (São Paulo, Brazil); the study was conducted adhering to the institution's guidelines for animal husbandry.

\subsection{In vitro studies with $S$. mansoni}

Schistosoma mansoni worms harvested from hamsters were washed in RPMI 1640 medium (Gibco) supplemented with $200 \mu \mathrm{g} / \mathrm{ml}$ of streptomycin, $200 \mathrm{IU} / \mathrm{ml}$ of penicillin (Invitrogen), and $25 \mathrm{mM}$ of Hepes. Adult worm pairs (male and female) were incubated in a 
24-well culture plate (Techno Plastic Products, TPP) containing $2 \mathrm{ml}$ of the same medium supplemented with $10 \%$ heat-inactivated calf serum at $37{ }^{\circ} \mathrm{C}$ in a $5 \% \mathrm{CO}_{2}$ atmosphere (Xiao et al., 2007). After 1 to $2 \mathrm{~h}$, piplartine was added to the culture, yielding a final drug concentration of 3.2 to $630.2 \mu \mathrm{M}$ (1 to $200 \mu \mathrm{g} / \mathrm{ml}$ ) (Xiao and Catto, 1989). Piplartine was dispensed from a stock solution of $6302.4 \mu \mathrm{M}(2000 \mu \mathrm{g} / \mathrm{ml})$ in RPMI 1640 containing 2\% dimethyl sulfoxide (DMSO). The control worms were assayed in RPMI 1640 medium with 2\% DMSO as a negative control group and in $10 \mu \mathrm{M}$ PZQ as a positive control group. All experiments were carried out in triplicates and were repeated at least three times. Worm motor activity, egg output (oviposition), tegumental alterations, and survival of the parasites were monitored on daily basis for 5 days using an inverted microscope and a stereomicroscope (SMZ 1000, Nikon) (Xiao et al., 2007). LC $_{50}$ value was calculated from a dose-response inhibition graph.

\subsection{Tegumental changes}

The quantification of the number of tubercles was performed using a confocal microscope. After the established times or in the occurrence of death, the parasites were fixed in Formalin-acetic-alcohol solution (FAA) and analyzed under a confocal microscope (Laser Scanning Microscopy, LSM 510 META, Zeiss) at $488 \mathrm{~nm}$ (exciting) and $505 \mathrm{~nm}$ (emission) as described by (Moraes et al., 2009). A minimum of three areas of the tegument of each

parasite were assessed. The numbers of tubercles were counted in $20,000 \mu \mathrm{m}^{2}$ of area calculated with the Zeiss LSM Image Browser software.

\subsection{Cytotoxicity assay}

The Vero mammalian cells (African green monkey kidney fibroblast) used in this study were obtained from the American Type Culture Collection (ATCC CCL-81; Manassas, VA) 
and provided by Ronaldo Z. Mendonça (Laboratory of Parasitology, Butantan Institute, São Paulo, Brazil). The cytotoxicity was determined by the crystal violet method according to a previously described procedure (Cruz et al., 2005). Briefly, Vero cells maintained in Dulbecco's Minimum Essential Medium (Gibco, BRL) supplemented with 10\% heatinactivated calf serum were seeded at a density of $5 \times 10^{6}$ cells per ml into 96 -well culture microplates (Nalge Nunc International). Control cells and/or cells treated with different concentrations of piplartine were incubated at $37^{\circ} \mathrm{C}$ in a $5 \% \mathrm{CO}_{2}$ atmosphere. After 2, 24, 48, 72 , and $96 \mathrm{~h}$ of incubation, the supernatants were removed and the remaining live cells were assessed by fixing and staining them with crystal violet $(0.2 \%$ in $20 \%$ methanol). The absorbance was measured by reading each well at $595 \mathrm{~nm}$ in a microplate reader.

\subsection{Statistical analysis}

The statistical tests were performed with the GRAPHPAD PRISM (version 4.0) software. Significant differences were determined by one-way analysis of variance (ANOVA) and applying Tukey's test for multiple comparisons with a level of significance set at $\mathrm{P}<0.05$.

\section{Results}

\subsection{Effect of piplartine on adult schistosomes survival}

The survival of 49-day-old adult worms of S. mansoni was assessed in vitro by incubation with different concentrations of piplartine. The effect of piplartine on the mortality rate of both male and female adult worms was analyzed with respect to the concentration and incubation time. All worms died at a concentration of $472.7 \mu \mathrm{M}$ after $2 \mathrm{~h}$. The lethal effect was also noted at doses of $15.8,12.6$ and $9.5 \mu \mathrm{M}$ after 24,48 and $72 \mathrm{~h}$, respectively. In contrast, the worms remained viable in the negative control group until the end of the incubation period (120 h), whereas PZQ $10 \mu \mathrm{M}$, the positive control, caused the death of all 
the parasites within $2 \mathrm{~h}$ (Table 1). The doses of piplartine required to kill $50 \%\left(\mathrm{LC}_{50}\right)$ of adult worms in vitro were 393.9 and $12.6 \mu \mathrm{M}$ in 2 and $24 \mathrm{~h}$, respectively. No significant difference was observed in the mortality rate between male and female parasites.

Subsequently, the effect of piplartine on the motor activity of the worms was examined, and a dose-dependent reduction of activity was observed. For example, a decrease in motor activity was observed in $12(60 \%)$ adult parasites after $2 \mathrm{~h}$ of exposure to piplartine at a concentration of $315.1 \mu \mathrm{M}$ (Table 1). The body contractions were abolished in all worms treated with piplartine regardless of the administered dose. Adult parasites exposed to the amide remained elongated throughout the observation time, but no significant differences in worm length could be observed, including in the negative control group. In contrast, all the adult worms incubated in a medium containing $10 \mu \mathrm{M}$ PZQ became immediately contracted, and their motor activities were significantly reduced (Table 1).

\subsection{Effect of piplartine on the reproductive fitness of $\boldsymbol{S}$. mansoni}

Considering the strong lethal effect of piplartine on adult schistosomes, the in vitro oviposition was continually monitored to assess the sexual fitness of treated worms. Piplartine at doses higher than $9.5 \mu \mathrm{M}$ inhibited $100 \%$ of egg laying when compared to the control group. However, this effect apparently resulted from the separation of the worms caused by piplartine, which prevented any reproductive process. At sub-lethal concentrations of piplartine, i.e., less than $9.5 \mu \mathrm{M}$, the parasites remained coupled, but the total number of eggs laid by the surviving worms was significantly reduced $(\mathrm{P}<0.001)$. After $120 \mathrm{~h}$, all the worm couples of the control group had produced eggs. Individual counts per worm couple in piplartine-free medium and in a medium with $6.3 \mu \mathrm{M}$ of piplartine were $120 \pm 50$ and $30 \pm 20$ (mean \pm SD of ten worm couples), respectively. The cumulative number of eggs laid per 
worm couple was established only for those cultures containing live and coupled male and female worms (Fig. 2).

\subsection{Morphological alterations on $S$. mansoni induced by piplartine}

In addition to the mortality rate and changes in the motor capacity of $S$. mansoni adults, the results highlighted the effect of piplartine on the parasite's tegument (Table 1). The morphological alterations of the tegument occurred in a dose-dependent manner and were more pronounced in male than in female adults. No tegumental changes in adult worms were observed in the negative control group, whereas the $10 \mu \mathrm{M}$ PZQ group had tegumental alteration in all the worms. To further describe the effects on the tegument, we performed the confocal microscopy analysis, which showed alterations caused by piplartine on the tubercles in a dose-dependent manner at doses higher than $15.8 \mu \mathrm{M}$ (Figs. 3 and 4). For example, the number of intact tubercles in an area of $20,000 \mu \mathrm{m}^{2}$ on the schistosome's tegument in male worms of the negative control was 49 , while in the group exposed to $630.2 \mu \mathrm{M}$ of piplartine was 2.

Additional morphological aberrations were observed after 2-24 h of incubation with 315.1 to $630.2 \mu \mathrm{M}$ of piplartine; moreover, at this concentration range, all adult male schistosomes showed morphological changes on the oral and ventral sucker regions (Fig. 5). In contrast, female schistosomes showed tegument damage caused by piplartine but only at doses higher than $157.6 \mu \mathrm{M}$. Moreover, no morphological alterations could be observed in the oral and ventral suckers of female worms after incubation with piplartine at concentrations of 315.1 to $630.2 \mu \mathrm{M}$. There was no apparent alteration in the surface of the oral and ventral suckers when the schistosomes were incubated in the negative (DMSO 2\%) and positive (PZQ $10 \mu \mathrm{M})$ control groups. 


\subsection{Effect of piplartine on mammalian cells}

To examine whether piplartine is tolerated by mammalian cells, we incubated monkey kidney fibroblasts (Vero cells) with piplartine at different concentrations that were lethal to $S$. mansoni adult worms (9.5 to $31.5 \mu \mathrm{M})$. The cytotoxicity was not detected in Vero cells after the treatment with piplartine at the maximum dose tested. Based on three independent experiments in triplicate, the cells exposed to piplartine at 9.5, 12.6, 15.8, and $31.5 \mu \mathrm{M}$ during $2,24,48,72$, and $96 \mathrm{~h}$, had no noticeable effects on their viability. Likewise, no cytotoxicity was detected after treatment with PZQ at same concentrations.

\section{Discussion}

Recently, several in vitro studies have been performed to search for new active compounds against Schistosoma species (De Araújo et al., 2007; Mahran et al., 2007; De Oliveira Penido et al., 2008; Boissier et al., 2009; Botros et al., 2009; Magalhães et al., 2009, 2010). In particular, natural products are one of the major sources for prospecting potential antiparasitic compounds. The Brazilian flora is rich in medicinal plants, and Piperaceae is a tropical plant family with a high potential for providing biocidal compounds, including amides and alkaloids (Parmar et al., 1997; Kato and Furlan, 2007). In this study, we evaluated the in vitro effect of piplartine, an amide found in Piper species, on S. mansoni adult worm mortality and fecundity. To the best of our knowledge, this is the first report to test the in vitro schistosomicidal activity of piplartine.

Several parameters, such as motor activity, tegumental changes and oviposition, are often evaluated as indicators of biological activity and toxicity in studies with schistosomes species (Xiao et al., 1985, 2007; Xiao and Catto, 1989; William et al., 2001; Sanderson et al., 2002; Pica-Mattoccia and Cioli, 2004; De Araújo et al., 2007; De Oliveira Penido et al., 2008; Boissier et al., 2009; Magalhães et al., 2009, 2010). Here, the temporal efficacy of the 
piplartine was tested in vitro against $S$. mansoni male and female adult worms. The following parameters were assessed: (1) the effect of piplartine on schistosome survival; (2) the effect of piplartine on reproductive fitness of S. mansoni, i.e. egg output per worm pair; (3) the effect of piplartine on motor activity; and (4) the changes on the tegumental surface of S. mansoni. All these effects occurred in a dose-dependent manner.

Disparities in drug susceptibility between male and female $S$. mansoni have been previously reported in several in vitro activity trials. Male worms of $S$. mansoni are often more susceptible than female worms in praziquantel resistance studies (Liang et al., 2001; Pica-Mattoccia and Cioli, 2004) and in studies that evaluated the bioactivity of a ginger extract (Sanderson et al. 2002). In contrast, results with compounds other than praziquantel, such as aminoalkanethiosulfuric acids (De Oliveira Penido et al., 2008) and 2-(butylamino)-1phenyl-1-ethanethiosulfuric acid (De Araújo et al., 2007), showed higher survival rates for male than for female. Remarkably, our in vitro data demonstrated that piplartine exhibited an optimal activity against the adult stage with no differential sensitivity between male and female worms. Indeed, piplartine was effective at low concentrations, and high lethality observed at concentration as low as $9.5 \mu \mathrm{M}$.

Concerning the reproductive fitness of $S$. mansoni adults, other plant constituents have shown effects on the worm's egg production. For example, curcumin, extracted from the rhizome of Curcuma longa (Magalhães et al., 2009), and some phloroglucinol derivatives, obtained from the rhizomes of Dryopteris species (Magalhães et al., 2010), presented in vitro effects on the schistosome's oviposition. A decrease in the schistosome oviposition was also observed using Nigella sativa crushed seeds (black seeds) (Mohamed et al., 2005) and a ginger rhizome extract (Zingiber officinale) (Sanderson et al., 2002). Our data showed that the incubation of adult $S$. mansoni with piplartine at doses higher than $9.5 \mu \mathrm{M}$ kept the male and female adult worms separated, which prevented the mating process and further oviposition. In 
contrast, at piplartine doses lower than $9.5 \mu \mathrm{M}$, the worms remained coupled and produced eggs at a reduced rate (Fig. 2). Thus, piplartine is toxic at higher doses, while at sub-lethal doses, it significantly interferes with the reproductive fitness of $S$. mansoni.

Similarly, our morphological studies revealed severe tegumental changes that occurred rapidly after incubation of $S$. mansoni adult worms with piplartine concentrations higher than 15.8 $\mu \mathrm{M}$. The microscopy analysis revealed progressive damages on the tegument surface causing its disruption. The changes in the tegument surface included peeling as well as formation and collapsing of tubercles, indicating straight damage to the cells in a direct dosedependent effect. In addition, morphological changes on oral and ventral sucker regions were observed only at doses higher than $157.6 \mu \mathrm{M}$. These tegumental damages were similar to those reported in studies with praziquantel (William et al., 2001). A severe damage to the oral and ventral sucker regions was also reported with praziquantel enantiomers (Shuhua et al., 2000). Thus, the tegumental damage occurs after incubations with doses higher than the lethal concentrations $(9.5 \mu \mathrm{M})$ suggesting that the worm's death is caused by different mechanisms. Indeed, the tegumental damage may not always result in death (Shuhua et al., 2000).

Furthermore, the tegumental damages were less pronounced or not observed in female worms, which showed severe tegument alterations only with piplartine doses higher than 157.6 $\mu \mathrm{M}$ (data not show). Moreover, female worms showed no damage in the oral and ventral sucker apparatus after incubation with piplartine, even at concentrations of 315.1 to $630.2 \mu \mathrm{M}$. Severe damage in the tegument, but not in the sucker apparatus, was also reported in female $S$. mansoni worms treated with artemether (Xiao et al., 1985, 2000a). The male worms in the praziquantel group were more susceptible to the tegumental action than female worms. The tegument is extremely important to the infection success and survival in the host, and it has been a major target for the development of antischistosomal drugs. Therefore, most of the currently used drugs against schistosomes, such as praziquantel (Shuhua et al., 2000; 
William et al., 2001), mefloquine (Manneck et al., 2010) and artemether (Xiao et al., 2000b), act by damaging the schistosome tegument.

The mechanism by which piplartine exerts its effects on the tegument remains unclear. Interestingly, the in vitro effects of piplartine on $S$. mansoni adults better correlate with the muscular function (motor activity) than with the tegumental destruction. In other words, the induction of lethal tegumental alterations requires higher concentrations of piplartine than the required to provoke muscular paralysis followed by death. Indeed, concentrations of piplartine 2-20 times higher were required to produce morphological alterations of S. mansoni compared to the doses causing paralysis.

Regarding the cytotoxicity of piplartine in mammalian cells, the in vitro studies with piplartine $10 \mu \mathrm{g} / \mathrm{ml}(31.5 \mu \mathrm{M})$ showed a lack of significant toxicity in human peripheral blood mononuclear cells after 24, 48, and $72 \mathrm{~h}$ (Bezerra et al., 2007). In this study, we also examined if piplartine is tolerated by mammalian cells (Vero cells), and this amide showed no cytotoxicity against Vero cells when exposed to concentrations up to three times higher than the ones with schistosomicidal effects $(31.5 \mu \mathrm{M})$. Thus, the in vitro schistosomicidal activity of piplartine was not associated with cytotoxic effects and its mechanism is still unclear.

In conclusion, we demonstrated that piplartine is an effective compound against $S$. mansoni in vitro. The mortality rate, the effect on the reproductive fitness and the extensive morphological tegument alterations on adult worms showed that piplartine is a promising schistosomicidal compound. Further studies are required to elucidate the mechanism(s) of piplartine toxicity against schistosomes and to evaluate its suitability for designing novel antihelminthic agents.

\section{Acknowledgments}


We thank Mr. Alexsander Seixas de Souza for his excellent technical assistance with confocal microscopy. We are grateful for the financial support received from the Fundação de Amparo à Pesquisa do Estado de São Paulo (FAPESP, Brazil). This paper is dedicated to the memory of Dra. Toshie Kawano, who died on March 30, 2010. Kawano will be remembered by students, faculty, and co-workers alike as an accomplished scientist, dedicated teacher, inspiring mentor, and loyal friend. We, the people of the Laboratory of Parasitology, will honor her by continuing the research that brought so much joy to her life.

\section{References}

Bezerra, D.P., Militão, G.C., de Castro, F.O., Pessoa, C., de Moraes, M.O., Silveira, E.R., Lima, M.A., Elmiro, F.J., Costa-Lotufo, L.V., 2007. Piplartine induces inhibition of leukemia cell proliferation triggering both apoptosis and necrosis pathways. Toxicology in Vitro 21, 1-

8.

Bodiwala, H.S., Singh, G., Singh, R., Dey, C.S., Sharma, S.S., Bhutani, K.K., Singh, I.P., 2007. Antileishmanial amides and lignans from Piper cubeba and Piper retrofractum. Journal of Natural Medicines 61, 418-421.

Boissier, J., Coslédan, F., Robert, A., Meunier, B., 2009. In vitro activities of trioxaquines against Schistosoma mansoni. Antimicrobial Agents and Chemotherapy 53, 4903-4906.

Botros, S.S., William, S., Beadle, J.R., Valiaeva, N., Hostetler, K.Y., 2009.

Antischistosomal activity of hexadecyloxypropyl cyclic 9-(S)-[3-hydroxy-2(phosphonomethoxy)propyl]adenine and other alkoxyalkyl esters of acyclic nucleoside phosphonates assessed by schistosome worm killing in vitro. Antimicrobial Agents and Chemotherapy 53, 5284-5287. 
Caffrey, C.R., 2007. Chemotherapy of schistosomiasis: present and future. Current Opinion in Chemical Biology 11, 433-439.

Cícero Bezerra Felipe F., Trajano Sousa Filho J., de Oliveira Souza, L.E., Alexandre Silveira J., Esdras de Andrade Uchoa, D., Rocha Silveira, E., Deusdênia Loiola Pessoa O., de Barros Viana, G.S., 2007. Piplartine, an amide alkaloid from Piper tuberculatum, presents anxiolytic and antidepressant effects in mice. Phytomedicine 14, 605-612.

Cotinguiba, F., Regasini, L.O., da Silva Bolzani, V., Debonsi, H.M., Duó Passerini, G., Cicarelli, R.M.B., Kato, M.J., Furlan, M., 2009. Piperamides and their derivatives as potential anti-trypanosomal agents. Medicinal Chemistry Research 18, 703-711.

Cruz, A.H., Mendonça, R.Z., Petricevich, V.L., 2005. Crotalus durissus terrificus venom interferes with morphological, functional, and biochemical changes in murine macrophage. Mediators of Inflammation 2005, 349-359.

De Araújo, S.C., de Mattos, A.C., Teixeira, H.F., Coelho, P.M., Nelson, D.L., de Oliveira, M.C., 2007. Improvement of in vitro efficacy of a novel schistosomicidal drug by incorporation into nanoemulsions. International Journal of Pharmaceutics 337, 307-315.

De Oliveira Penido, M.L., Zech Coelho, P.M., de Mello, R.T., Piló-Veloso, D., de Oliveira, M.C., Kusel, J.R., Nelson, D.L., 2008. Antischistosoma activity of aminoalkanethiols, alkylaminoalkanethiosulfuric acids and the corresponding disulfides. Acta Tropica 108, 249-255.

Doenhoff, M., Cioli, D., Utzinger, J., 2008. Praziquantel: mechanisms of action, resistance and new derivatives for schistosomiasis. Current Opinion in Infectious Diseases 21, $659-667$.

Gryseels, B., Polman, K., Clerinx, J., Kestens, L., 2006. Human schistosomiasis. Lancet $368,1106-1118$. 
Hagan, P., Appleton, C.C., Coles, G.C., Kusel, J.R., Tchuem-Tchuenté, L.A., 2004. Schistosomiasis control: keep taking the tablets. Trends in Parasitology 20, 92-97.

Jaramillo, M.A., Manos, P.S., 2001. Phylogeny and patterns of floral diversity in the genus Piper (Piperaceae). American Journal of Botany 88, 706-716.

Kato, M.J., Furlan, M., 2007. Chemistry and evolution of the Piperaceae. Pure and Applied Chemistry 79, 529-538.

Liang, Y.S., Coles, G.C., Doenhoff, M.J., Southgate, V.R., 2001. In vitro responses of praziquantel-resistant and -susceptible Schistosoma mansoni to praziquantel. International Journal for Parasitology 31, 1227-1235.

Magalhães, L.G., Machado, C.B., Morais, E.R., Moreira, E.B., Soares, C.S., da Silva, S.H., Da Silva Filho, A.A., Rodrigues, V., 2009. In vitro schistosomicidal activity of curcumin against Schistosoma mansoni adult worms. Parasitology Research 104, 1197-1201.

Magalhães, L.G., Kapadia, G.J., da Silva Tonuci, L.R., Caixeta, S.C., Parreira, N.A., Rodrigues, V., Da Silva Filho, A.A., 2010. In vitro schistosomicidal effects of some phloroglucinol derivatives from Dryopteris species against Schistosoma mansoni adult worms. Parasitology Research 106, 395-401.

Mahran, M.A., William, S., Ramzy, F., Sembel, A.M., 2007. Synthesis and in vitro evaluation of new benzothiazole derivatives as schistosomicidal agents. Molecules 12, 622633.

Manneck, T., Haggenmüller, Y., Keiser, J., 2010. Morphological effects and tegumental alterations induced by mefloquine on schistosomula and adult flukes of Schistosoma mansoni. Parasitolology 137, 85-98.

Mohamed, A.M., Metwally, N.M., Mahmoud, S.S., 2005. Sativa seeds against Schistosoma mansoni different stages. Memórias do Instituto Oswaldo Cruz 100, 205-211. 
Mølgaard, P., Nielsen, S.B., Rasmussen, D.E., Drummond, R.B., Makaza, N., Andreassen, J., 2001. Anthelmintic screening of Zimbabwean plants traditionally used against schistosomiasis. Journal of Ethnopharmacology 74, 257-264.

Moraes, J., Silva, M.P., Ohlweiler, F.P., Kawano, T., 2009. Schistosoma mansoni and other larval trematodes in Biomphalaria tenagophila (Planorbidae) from Guarulhos, São Paulo State, Brazil. Revista do Instituto de Medicina Tropical de São Paulo 51, 77-82.

Ndamba, J., Nyazema, N., Makaza, N., Anderson, C., Kaondera, K.C., 1994. Traditional herbal remedies used for the treatment of urinary schistosomiasis in Zimbabwe. Journal of Ethnopharmacology 42, 125-132.

Navickiene, H.M., Alécio, A.C., Kato, M.J., Bolzani, V.D., Young, M.C., Cavalheiro, A.J., Furlan, M., 2000. Antifungal amides from Piper hispidum and Piper tuberculatum. Phytochemistry 55, 621-626.

Navickiene, H.M., Bolzani, V. da S, Kato, M.J., Pereira, A.M., Bertoni, B.W., França, S.C., Furlan, M., 2003. Quantitative determination of anti-fungal and insecticide amides in adult plants, plantlets and callus from Piper tuberculatum by reverse-phase high-performance liquid chromatography. Phytochemical Analysis 14, 281-284.

Parmar, V.S., Jain, S.C., Bisht, K.S., Jain, R., Taneja, P., Jha, A., Tyagi, O.M., Prasad, A.K., Wengel, J., Olsen, C.E. and Boll, P.M., 1997. Phytochemistry of the genus Piper. Phytochemistry 46, 597-673.

Pica-Mattoccia, L., Cioli, D., 2004. Sex- and stage-related sensitivity of Schistosoma mansoni to in vivo and in vitro praziquantel treatment. International Journal for Parasitology $34,527-533$.

Prasad, A.K., Kumar, V., Arya, P., Kumar, S., Dabur, R., Singh, N., Chhillar, A.K., Sharma, G., Ghosh, B., Wengel, J., Olsen, C.E. and Parmar, V.S., 2005. Investigations toward 
new lead compounds from medicinally important plants. Pure and Applied Chemistry 77, 2540.

Sanderson, L., Bartlett, A., Whitfield, P.J., 2002. In vitro and in vivo studies on the bioactivity of a ginger (Zingiber officinale) extract towards adult schistosomes and their egg production. Journal of Helminthology 76, 241-247.

Shuhua, X., Binggui, S., Chollet, J., Tanner, M., 2000. Tegumental changes in adult Schistosoma mansoni harboured in mice treated with praziquantel enantiomers. Acta Tropica $76,107-117$.

Steinmann, P., Keiser, J., Bos, R., Tanner, M., Utzinger, J., 2006. Schistosomiasis and water resources development: systematic review, meta-analysis, and estimates of people at risk. The Lancet Infectious Diseases 6, 411-425.

Smithers, S.R., Terry, R.J., 1965. The infection of laboratory hosts with cercariae of Schistosoma mansoni and the recovery of the adult worms. Parasitology 55, 695-700.

Vasques da Silva, R., Navickiene, H.M., Kato, M.J., Bolzani, V.da S., Méda, C.I., Young, M.C., Furlan, M., 2002. Antifungal amides from Piper arboreum and Piper tuberculatum. Phytochemistry 59, 521-527.

William, S., Botros, S., Ismail, M., Farghally, A., Day, T.A., Bennett, J.L., 2001. Praziquantel-induced tegumental damage in vitro is diminished in schistosomes derived from praziquantel-resistant infections. Parasitology 122, 63-66.

Xiao, S.H., Catto, B.A., Webster, L.T.Jr., 1985. Effects of praziquantel on different developmental stages of Schistosoma mansoni in vitro and in vivo. The Journal of Infectious Diseases 151, 1130-1137.

Xiao, S.H., Catto, B.A., 1989. In vitro and in vivo studies of the effect of artemether on Schistosoma mansoni. Antimicrobial Agents and Chemotherapy 33, 1557-1562. 
Xiao, S., Binggui, S., Chollet, J., Tanner, M., 2000a. Tegumental changes in 21-day-old Schistosoma mansoni harboured in mice treated with artemether. Acta Tropica 75, 341-348.

Xiao, S., Shen, B., Chollet, J., Utzinger, J., Tanner, M., 2000b. Tegumental changes in adult Schistosoma mansoni harbored in mice treated with artemether. The Journal of Parasitology 86, 1125-1132.

Xiao, S.H., Keiser, J., Chollet, J., Utzinger, J., Dong, Y., Endriss, Y., Vennerstrom, J.L., Tanner, M., 2007. In vitro and in vivo activities of synthetic trioxolanes against major human schistosome species. Antimicrobial Agents and Chemotherapy 51, 1440-1445. 


\section{Legends to Figures}

Fig. 1. Chemical structure of piplartine [5,6-dihydro-1-[1-oxo-3-(3,4,5-trimethoxyphenyl)-2propenyl]-2(1H)-pyridinone].

Fig. 2. In vitro effect of piplartine on Schistosoma mansoni oviposition. Adult worm couples were incubated with piplartine, and at the indicated time periods, the cumulative number of eggs per worm couple was assessed and scored using an inverted microscope. Values are means \pm SD (bars) of ten worm couples. $* \mathrm{P}<0.05,{ }^{*} \mathrm{P}<0.01$, and $* * * \mathrm{P}<0.001$ compared with untreated groups.

Fig. 3. Effect of piplartine on the tegument of Schistosoma mansoni. After 24 hours of incubation with piplartine, adult male worms were fixed in FAA solution and fluorescent images were obtained using confocal microscopy (Carl Zeiss LSM 510 META). The images were analyzed with the Zeiss LSM Image Browser software. (A) Negative control. (B) piplartine $6.3 \mu \mathrm{M}$. (C) piplartine $15.8 \mu \mathrm{M}$. (D) piplartine $31.5 \mu \mathrm{M}$. (E) piplartine $78.8 \mu \mathrm{M}$. (F) piplartine $157.6 \mu \mathrm{M}$. (G) piplartine $315.1 \mu \mathrm{M}$. (H) piplartine $393.9 \mu \mathrm{M}$. (I) piplartine 472.7 $\mu \mathrm{M}$. (J) piplartine $630.2 \mu \mathrm{M}$. Bars $=50 \mu \mathrm{m}$.

Fig. 4. Effect of the piplartine amide on tubercles of Schistosoma mansoni male worms. The quantification of the number of tubercles was performed using confocal microscopy.

Indicated are numbers of intact tubercles and these numbers were measured in a $20,000 \mu \mathrm{m}^{2}$ of area calculated with the Zeiss LSM Image Browser software. Praziquantel (PZQ, $10 \mu \mathrm{M})$ was used as positive control. A minimum of three tegument areas of each parasite were 
assessed. Values are means $\pm \mathrm{SD}$ (bars) of ten male adult worms. $* * \mathrm{P}<0.01$ and $* * * \mathrm{P}<$ 0.001 compared with untreated groups.

Fig. 5. Morphological changes on the oral and ventral sucker region of Schistosoma mansoni after incubation with piplartine. After 24 hours of incubation with piplartine, adult male worms were fixed in FAA solution and fluorescent images were obtained using confocal microscopy (Carl Zeiss LSM 510 META). The images were analyzed with the Zeiss LSM Image Browser software. (A) Control. (B) piplartine $157.6 \mu \mathrm{M}$. (C) piplartine $315.1 \mu \mathrm{M}$. (D) piplartine $472.7 \mu \mathrm{M}$. (E) piplartine $630.2 \mu \mathrm{M}$. Bars $=100 \mu \mathrm{m}$. 
Fig. 1

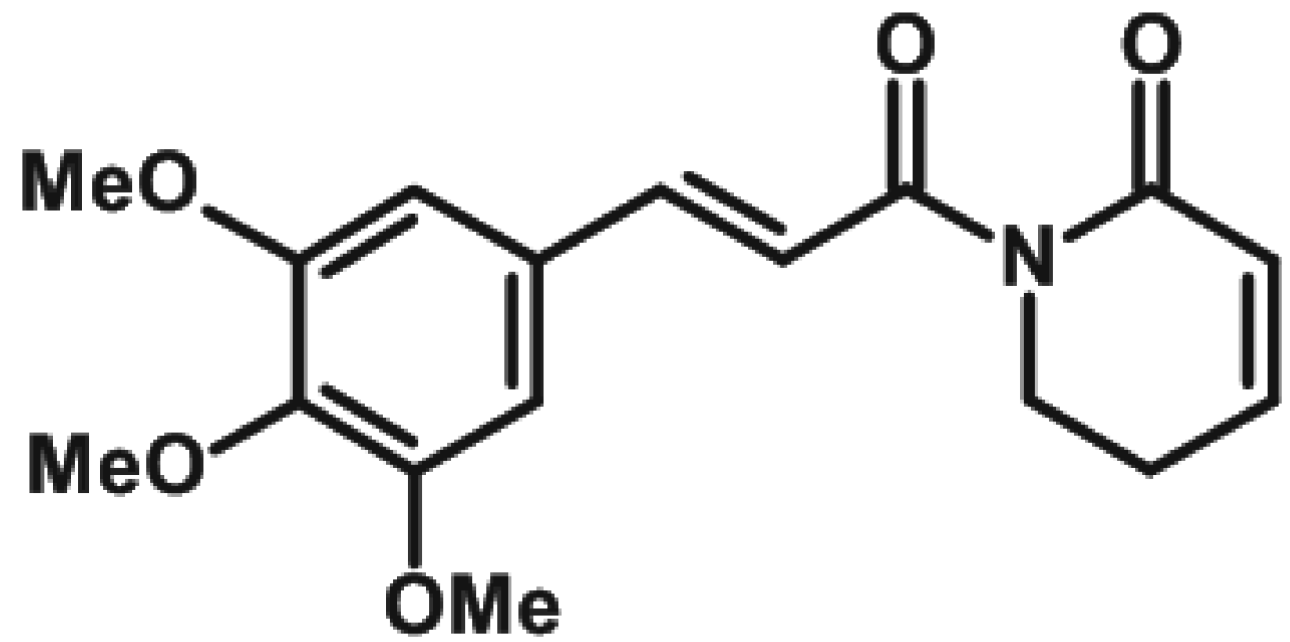

Fig. 2

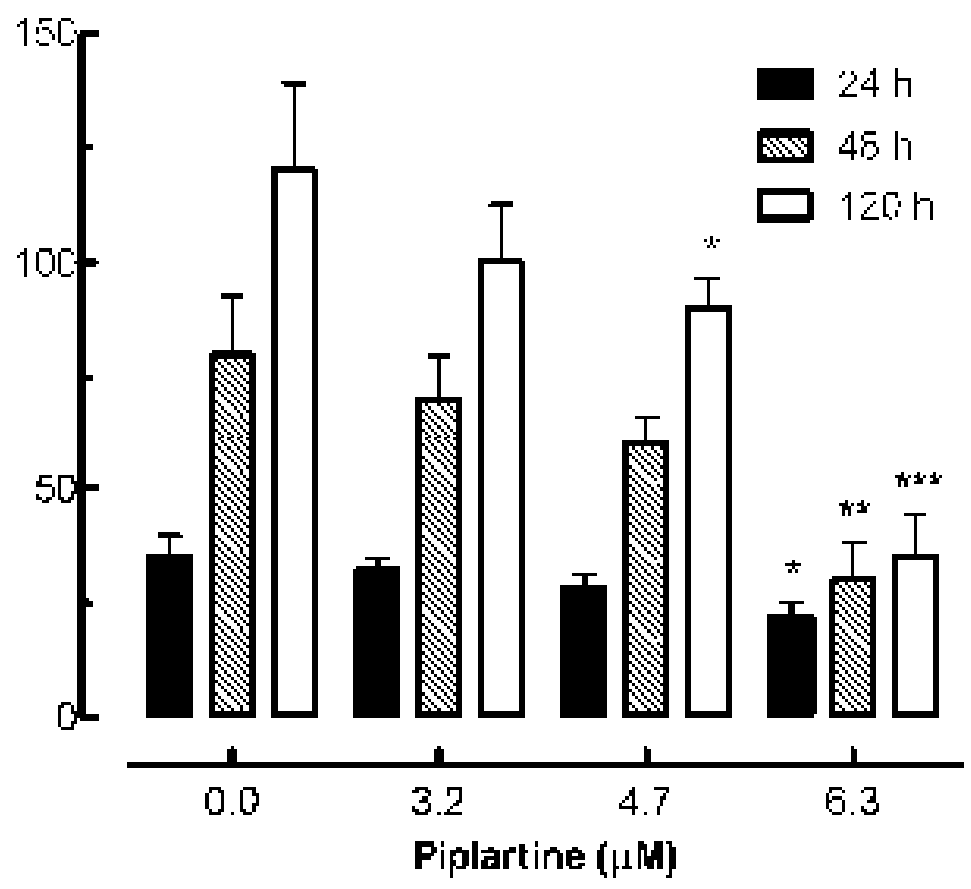

Fig. 3 

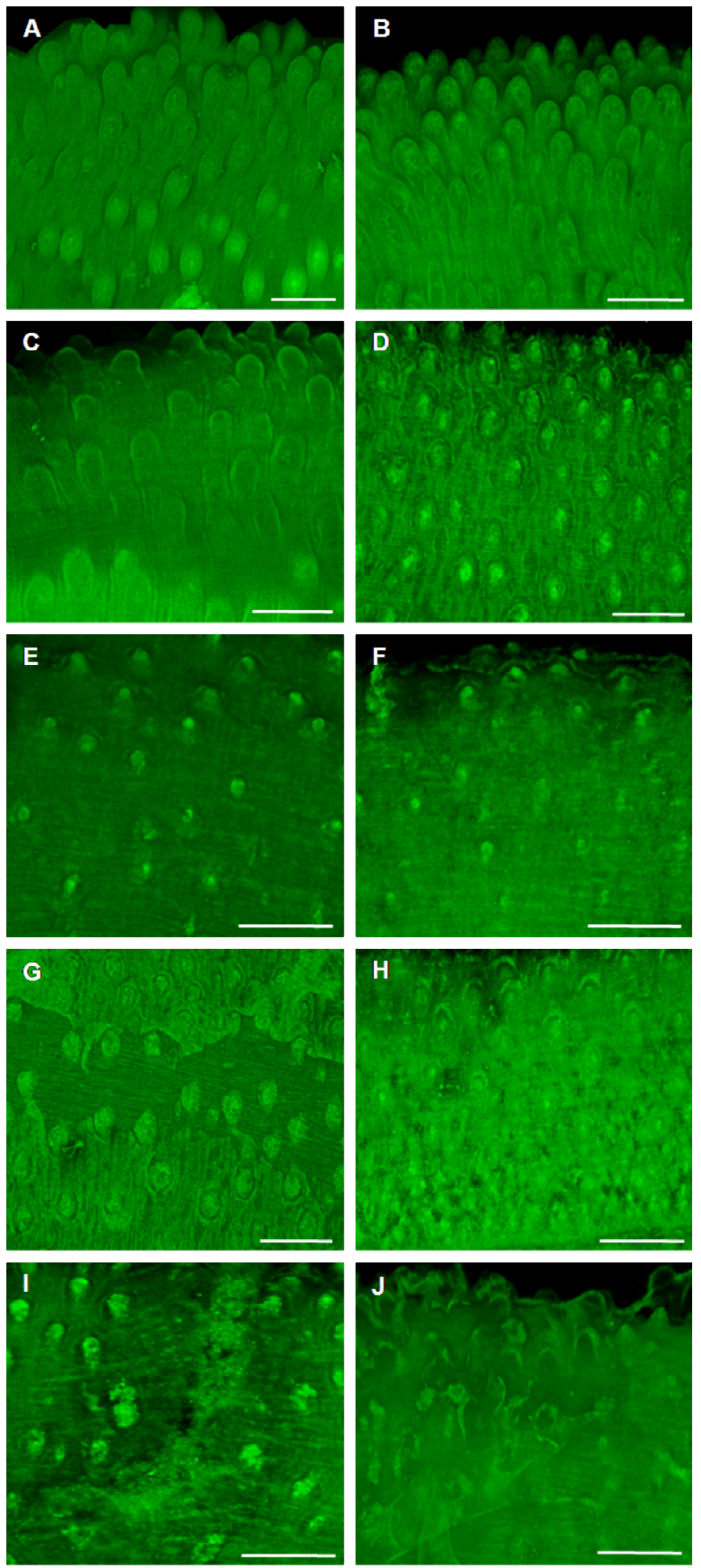
Fig. 4

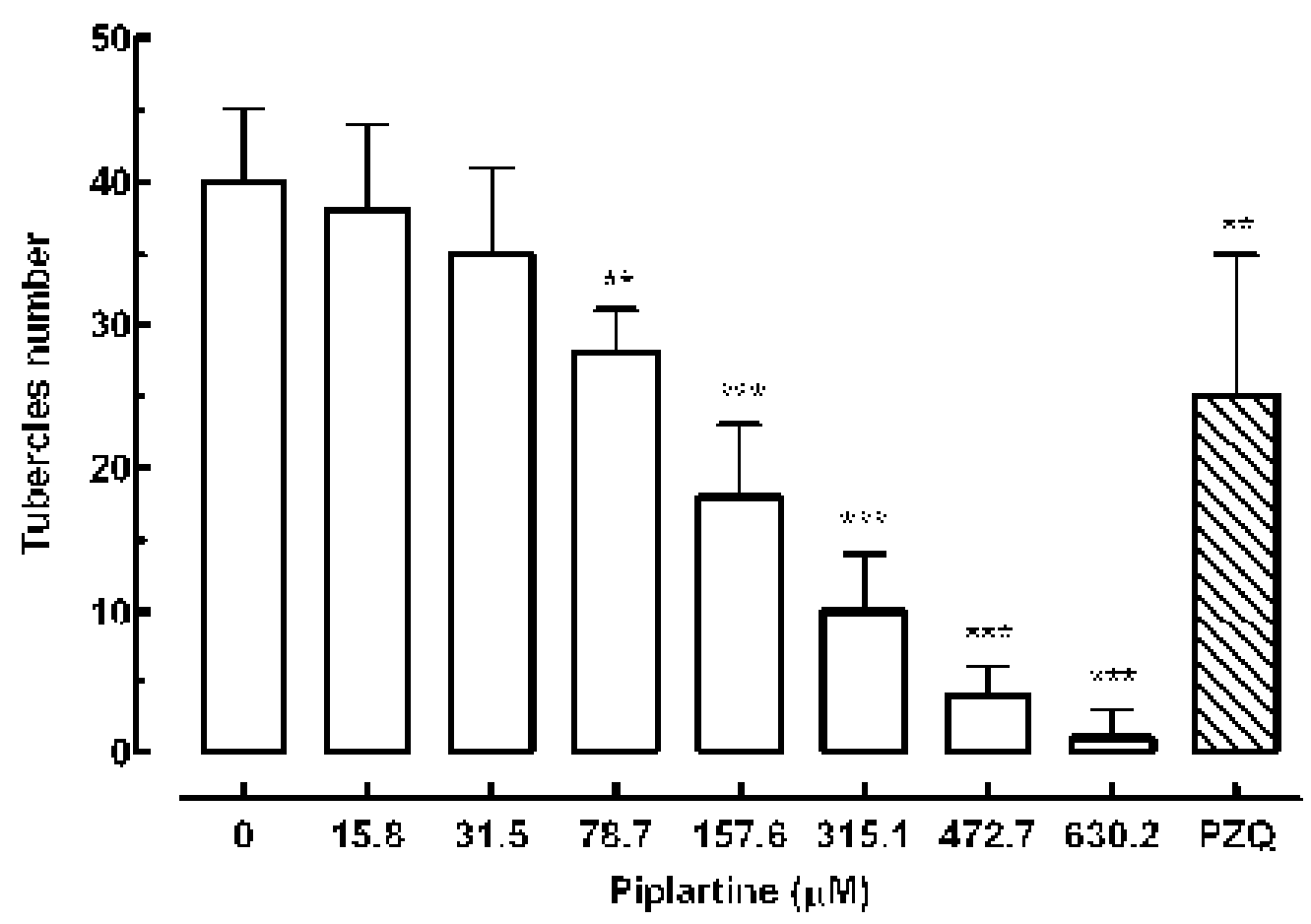


Fig. 5
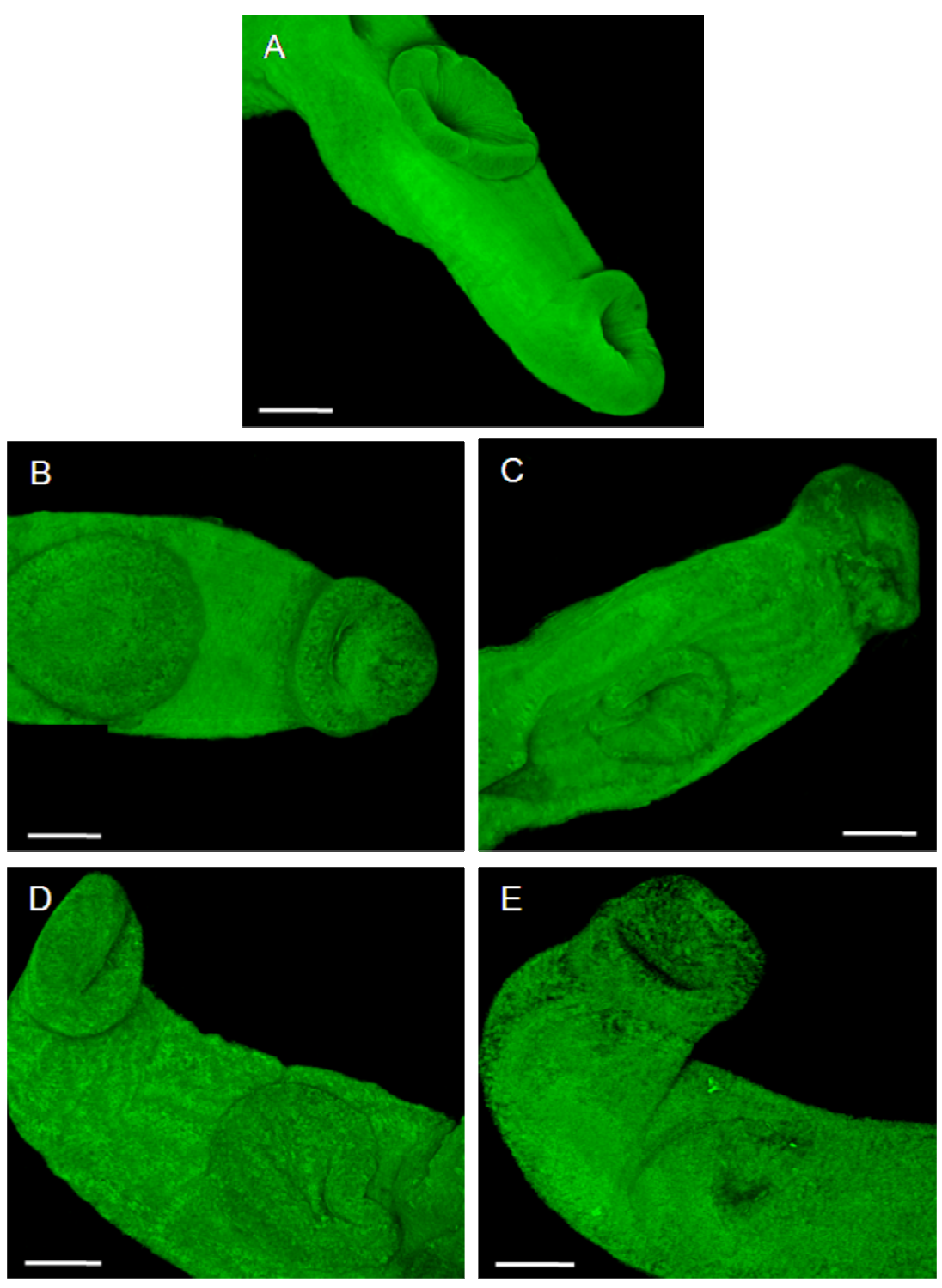


\section{ANEXO - B}

Evaluation of the in vitro activity of dermaseptin 01 , cationic antimicrobial peptide, against Schistosoma mansoni 


\section{Evaluation of the in vitro Activity of Dermaseptin 01, a Cationic Antimicrobial Peptide, against Schistosoma mansoni}

by Josué de Moraes $\left.{ }^{\text {va }}\right)^{b}$ ), Carlos Nascimento ${ }^{a}$ ), Leiz M. C. V. Miura ${ }^{c}$ ), José R. S. A. Leite ${ }^{c}$ ), Eliana Nakano ${ }^{a}$ ), and Toshie Kawano ${ }^{2}$ )

a) Laboratório de Parasitologia, Instituto Butantan, Avenida Vital Brasil 1500, 05503.900, São Paulo, SP, Brazil (phone: + 55•11.37267222 ext. 2281/2158; fax: +55-11·37261505; e-mail: josuem@usp.br, josuemoraes@ig.com.br)

b) Instituto de Ciências Biomédicas, Universidade de São Paulo, São Paulo, SP, Brazil

c) Núcleo de Pesquisa em Biodiversidade e Biotecnologia, BIOTEC, Campus Ministro Reis Velloso, Universidade Federal do Piauí, Parnaíba, PI, Brazil

Dedicated to the memory of Dra. Toshie Kawano, who died on March 30, 2010. Dra. Kawano will be remembered by students, faculty members, and co-workers as an accomplished scientist, dedicated teacher, inspiring mentor, and loyal friend. The collaborators of the Laboratory of Parasitology will

honor her by continuing the research that brought so much joy to her life.

Schistosomiasis is a neglected tropical disease that remains a considerable public health problem worldwide. Since the mainstay of schistosomiasis control is chemotherapy with a single drug, praziquantel, drug resistance is a concern. Here, we examined the in vitro effects of dermaseptin 01 (DS 01), an antimicrobial peptide found in the skin secretion of frogs of the genus Phylomedusa, on Schistosoma mansoni adult worms. DS 01 at a concentration of $100 \mu \mathrm{g} / \mathrm{ml}$ reduced the worm motor activity and caused the death of all worms within $48 \mathrm{~h}$ in RPMI 1640 medium. At the highest sublethal concentration of antimicrobial peptide $(75 \mu \mathrm{g} / \mathrm{ml})$, a $100 \%$ reduction in egg output of paired female worms was observed. Additionally, DS 01 induced morphological alterations on the tegument of $S$ mansoni, and a quantitative analysis carried out by confocal microscopy revealed extensive destruction of the tubercles in a dose-dependent manner over the concentration range of $50-200 \mu \mathrm{g} / \mathrm{ml}$. It was the first time that an anthelmintic activity towards schistosomes has been reported for a dermaseptin. 
Evaluation of the in vitro Activity of Dermaseptin 01, Cationic Antimicrobial Peptide, Against Schistosoma mansoni

\author{
by Josué de Moraes*a ${ }^{\mathrm{b}}$ ), Carlos Nascimento ${ }^{\mathrm{a}}$ ), Leiz M.C.V. Miura ${ }^{\mathrm{c}}$ ), \\ José R.S.A. Leite $^{\mathrm{c}}$ ), Eliana Nakano ${ }^{\mathrm{a}}$ ), and Toshie Kawano ${ }^{\mathrm{a}}$ )
}

a) Laboratório de Parasitologia, Instituto Butantan, Avenida Vital Brasil 1500, 05503-900, São Paulo, SP, Brazil.

(Phone: +55 11 3726-7222 R. 2281/2158; fax: +55 11 3726-1505; e-mail adresses: josuem@usp.br, josuemoraes@ig.com.br).

b) Instituto de Ciências Biomédicas, Universidade de São Paulo, São Paulo, SP, Brazil.

c) Núcleo de Pesquisa em Biodiversidade e Biotecnologia, Campus Ministro Reis Velloso, Universidade Federal do Piauí, Parnaíba, PI, Brazil. 
Schistosomiasis is a neglected tropical disease that remains of considerable public health significance in worldwide. Since the mainstay of schistosomiasis control is chemotherapy with a single drug, praziquantel, drug resistance is a concern. Here, we examined the in vitro effects of dermaseptin 01, an antimicrobial peptide found in the skin secretion from frogs of the genus Phyllomedusa, on Schistosoma mansoni adult worms. Dermaseptin 01 at $100 \mu \mathrm{g} / \mathrm{ml}$ reduced worm motor activity and caused death of all worms within $48 \mathrm{~h}$ in a RPMI 1640 medium. At the highest sub-lethal concentration of antimicrobial peptide $(75 \mu \mathrm{g} / \mathrm{ml})$, a $100 \%$ reduction in egg output of paired female worms was observed. Additionally, dermaseptin 01 induced morphological alterations in the tegument of S. mansoni, and a quantitative analysis carried out by confocal microscopy revealed extensive destruction of the tubercles in a dosedependent manner in the range of $50-200 \mu \mathrm{g} / \mathrm{ml}$. It is the first time that the antiparasitic activity towards schistosomes has been reported for a dermaseptin. 
Introduction. - Schistosomiasis remains one of the most prevalent and debilitating disease in tropical and subtropical regions. This parasitic disease is the most important human helminth infection in terms of morbidity and mortality, and it is surpassed only by malaria on public health importance. More than 207 million people have been infected worldwide, while 779 million people remain under infection risk [1] [2]. Schistosoma mansoni is one of the most common etiological agents for human schistosomiasis and the disease pathology is typically a consequence of the inflammatory granulomatous reaction due to parasite egg deposition in the liver and other host tissues [3].

The treatment and control of schistosomiasis are based on a single drug, praziquantel (PZQ). It has minimal side effects, but the control of schistosomiasis with PZQ at population level faces problems, including the development of drug resistance [4] [5]. Given the potential for parasite resistance, development of new and effective schistosomicidal compounds is highly desirable [6-8].

Antimicrobial peptides are short cationic peptides made up of less than 50 amino acids. They are cationic and amphipathic peptide of variable length, structure, amino acid sequence, and spectrum of action [9] [10]. In addition, these peptides play an important role in host defense against pathogens, and they exert antimicrobial action through their effect on the membrane of target cells by a mechanism, whose details remains to be understood [9] [1113].

More than 80 antimicrobial peptides have been isolated from only twelve species of the Phyllomedusinae subfamily, belonging to the genera Agalychnis, Hylomantis, Pachymedusa, and Phyllomedusa [14]. In 1987, magainins from frog skin were discovered and these antimicrobial peptides have been shown to exhibit potent activity against numerous species of bacteria and fungi [15]. Subsequently, a number of other skin-derived antimicrobial peptides 
were discovered in different frog species, and among the most studied are the ones from the dermaseptin family [16-18].

Dermaseptins (DSs) are cationic antimicrobial peptides of 24-34 residues found in skin secretion of representatives of the frog genus Phyllomedusa [16] [19-21]. These peptides have been shown to exert activity against a wide range of microorganisms, including gram-negative and gram-positive bacteria [16] [19], filamentous fungi and yeast [22-24] as well as antiviral effects [25-27].

Additionally, it was shown that DSs have potent activity against causative agents of several neglected tropical diseases. These peptides exhibited significant in vitro activity against trypomastigote and epimastigote forms of Trypanosoma cruzi [16] and promastigote forms of Leishmania amazonensis [20] and L. chagasi [28]. Dermaseptins also showed in vitro antiplasmodium effects [29].

Besides the fact that DSs are active against a large spectrum of microorganisms, they have been considered promising candidates for new anti-infective drugs. As an advantage, it has been demonstrated that this compound do not induce significant cytolysis against mammalian blood cells [16] [30].

Dermaseptin 01 (DS 01) was previously shown to kill bacteria, fungi, and protozoa with irrelevant toxicity activity against mammalian cells [16] [24] [28]. This is a 29-residue-long peptide that was found in skin secretion of Phyllomedusa oreades, which is a newly described and endemic amphibian species of the Brazilian Savanna [16]. Although DSs have a broad range of activities, antihelminthic effects have not yet been reported. In the present study, we reported for the first time the in vitro activity of a DS, specifically DS 01, against S. mansoni. The efficacy of this peptide was examined regarding: a) schistosomes survival; b) reproductive fitness; c) motor activity; and d) alterations on S. mansoni tegumental surface examined through confocal microscopy. 
Results and Discussion. - 1. Effect of dermaseptin 01 on adult schistosomes survival. Schistosoma mansoni is the most widely used schistosome model for chemotherapeutic studies [31]. Dermaseptin 01 is a cationic antimicrobial peptide that was isolated from Phyllomedusa oreades (Fig. 1). In this study, the survival of 49-day-old adult worm pairs of S. mansoni was assessed in vitro with incubation with different concentrations of DS 01 . The effect of peptide on mortality rates of both male and female adult worms was analyzed regarding concentrations and incubation time. Bioassays revealed that DS 01 is potent anti-S. mansoni agents at concentrations up to $50 \mu \mathrm{g} / \mathrm{ml}$. All worms had died $24 \mathrm{~h}$ after incubation with $200 \mu \mathrm{g} / \mathrm{ml}$ of peptide. The lethal effect was also noted at doses of 100 and $50 \mu \mathrm{g} / \mathrm{ml}$ after 48 and 120 h, respectively (Fig. 2 and Table 1); whereas no deaths were observed in the control group.

Considering mortality rate, no significant difference was observed between male and female parasites (Fig. 2). On the other hand, disparities on drug susceptibility between males and females have been previously reported on some in vitro activity trials. Male worms of $S$. mansoni are often more susceptible than female worms on praziquantel resistance studies [5] [32] and studies on the bioactivity of a ginger extract [33]. However, results with compounds other such as aminoalkanethiosulfuric acids [34], 2-(butylamino)-1-phenyl-1ethanethiosulfuric acid [35], and artenusate [36] showed higher survival rates for males than females. Notwithstanding, our in vitro data demonstrated that DS 01 exhibited activity against adult stages and no significant differences in mortality rate between male and female worms were observed.

Besides, the effect of DS 01 on motor activity of worms was examined and a dosedependent motor activity decrease could be observed. For example, a decrease in motor activity was observed in $12(60 \%)$ adult parasites $120 \mathrm{~h}$ after exposure to $25 \mu \mathrm{g} / \mathrm{ml}$ of 
dermaseptin, and all worms showed reduction in motor activity after $24 \mathrm{~h}$ at a peptide concentration of $100 \mu \mathrm{g} / \mathrm{ml}$. The resulting data are summarized in Table 1 .

2. Effect of dermaseptin 01 on reproductive fitness of $\mathrm{S}$. mansoni. Considering the lethal effect of DS 01 on adult schistosomes, in vitro oviposition at sub-lethal concentration was continually monitored in order to assess sexual fitness of exposed worms. The cumulative numbers of eggs laid by each worm couple were established only for those cultures containing live and coupled male and female worms. Fig. 3 shows that when live worm pairs were incubated for 24 to $72 \mathrm{~h}$ with concentration ranging between 25 and $75 \mu \mathrm{g} / \mathrm{ml}$, the peptide was able to inhibit egg laying when compared to the control group. For example, after $72 \mathrm{~h}$ of incubation, worm pairs of $S$. mansoni exposed to 25,50 and $75 \mu \mathrm{g} / \mathrm{ml}$ of dermaseptin showed inhibited oviposition in about $61 \%, 91 \%$, and $100 \%$, respectively, when compared to the control.

Concerning reproductive fitness of $S$. mansoni adults, some compounds have shown effects on the egg production of worms. For example, curcumin, extracted from the rhizome of Curcuma longa [37], some phloroglucinol derivatives obtained from the rhizomes of Dryopteris species [38], and artenusate [36] presented in vitro inhibitory effects on schistosome oviposition. The decrease on egg-laying in schistosomes was also observed with the use of Nigella sativa crushed seeds (black seeds) [39] and an extract of ginger rhizomes (Zingiber officinale) [33]. Our data corroborates these in vitro studies and showed that DS 01 is toxic at higher doses, while at sub-lethal doses, it significantly interferes with the reproductive fitness of $S$. mansoni.

3. Tegumental surface alterations on $\mathrm{S}$. mansoni induced by dermaseptin 01 . In addition to mortality rate and changes in motor capacity of S. mansoni adults, the results highlighted the inducing effect of DS 01 on parasite's tegument morphological alterations (Table 1). Such events took place in a dose-dependent manner and were more pronounced on adult males. 
Confocal microscopy analysis showed significant damage in tubercles of all adult male worms after exposure to a medium containing peptide at concentrations of 50 to $200 \mu \mathrm{g} / \mathrm{ml}$, whereas no tegumental surface alterations was observed in the control group (Fig. 4). A pattern consisting of a combination of changes in surface morphology were detected and correlated to the death of the worms (Fig. 4 and Table 1).

Additionally, for the extraction of quantitative parameters, an area of $20,000 \mu \mathrm{m}^{2}$ was demarcated and tubercles were counted and evaluated as intact or altered. Morphological characterization by laser scanning microscopy revealed alterations caused by DS 01 on the tubercles in a dose-dependent manner at doses higher than $50 \mu \mathrm{g} / \mathrm{ml}$. For example, a decrease from 41 to 3 tubercles was observed on male schistosome tegument in control and $200 \mu \mathrm{g} / \mathrm{ml}$ of peptide assays, respectively. Dose-response relationships and tegumental surface alteration in S. mansoni following treatment with DS 01 in vitro are summarized in Fig. 5.

The tegument is extremely important to infection success and survival in the host and has been a major target for antichistosomal drugs. Therefore, most of the current used drugs against schistosomes such as praziquantel [40] [41], mefloquine [42] and artemether [43], act by damaging the schistosome tegument. Although the precise mechanism of action is not fully understood, antimicrobial peptides are generally assumed to kill target cells by disrupting the cell membrane(s) [9] [10] [44]. The DS 01 assayed in this study induced killing of S. mansoni and tegument disruption.

Most of the peptides of the dermaseptin family have a very broad range of antimicrobial activity [14]. The capacity of the dermaseptins to discriminate between mammalian and microbial cells is known for almost two decades [19] [45-47], and it is mainly due to the amino acid composition of the peptides and to the differences on the physical-chemical properties of membranes [45] [46] [48] [49]. 
As stated previously, the dermaseptin family of peptides may have potential use as therapeutic drugs, as they are not toxic to animals or plants. Consistent with the data reported above where the in vitro schistosomicidal activity of DS 01 was demonstrated, combined with its effect on reproductive fitness and tegumental alteration on adult worms, it is clear that these peptides are a promising antihelminthic agents. Further biological in vitro and in vivo studies are required to evaluate its suitability for designing novel antiparasitic agents.

Acknowledgments. - The authors thank Mr. Alexsander S. Souza for his excellent technical assistance with confocal microscopy, and MSc Leonardo S. Carvalho for correcting the English. This investigation received financial support from Fundação de Amparo à Pesquisa do Estado de São Paulo (FAPESP, Brazil) and Conselho Nacional de Desenvolvimento Cientifico e Tecnológico (CNPq, Process number 476700/2009-4). This paper is dedicated to the memory of Dra. Toshie Kawano, who died on March 30, 2010. Kawano will be remembered by students, faculty, and co-workers alike as an accomplished scientist, dedicated teacher, inspiring mentor, and loyal friend. We, the people of the Laboratory of Parasitology, will honor her by continuing the research that brought so much joy to her life.

\section{Experimental Part}

Peptide Synthesis. The dermaseptin 01 (Fig. 1B), which was first identified in skin secretion from tree frogs Phyllomedusa oreades (Fig. 1A) [16], was also characterized from P. hypochondralis [20]. It was synthesized by an automated bench-top simultaneous multiple solid-phase peptide synthesizer (PSSM 8 system from Shimadzu) was used for the solid-phase synthesis of all the peptides by the Fmoc-procedure [50]. The final peptides were deprotected 
in trifluoroacetic acid (TFA) and purified by semipreparative system of the High Performance Liquid Chromatography (HPLC) using an Econosil $\mathrm{C}_{18}$ column $(10 \mu, 22.5 \times 250 \mathrm{~mm})$ and a two-solvent system: (A) trifluoroacetic acid (TFA)/ $\mathrm{H}_{2} \mathrm{O}$ (1:1000) and (B) TFA/acetonitrile $/ \mathrm{H}_{2} \mathrm{O}(1: 900: 100)$. The column was eluted at a flow rate of $5 \mathrm{ml} / \mathrm{min}$ with a $10-60 \%$ gradient of solvent B over 30 or 45 min. Analytical HPLC was performed using a binary HPLC system with a SPD-10AV Shimadzu UV-Vis detector (Shimadzu, Kyoto, Japan), coupled to an Ultrasphere ${ }^{\circledR} \mathrm{C}_{18}$ column $(5 \mu, 4.6$ x $150 \mathrm{~mm})$ (Beckman instruments, Berkeley, CA, USA) which was eluted with solvent systems $\mathrm{A} 1\left(\mathrm{H}_{3} \mathrm{PO}_{4} / \mathrm{H}_{2} \mathrm{O}, 1: 1000\right)$ and $\mathrm{B} 1$ (acetonitrile/ $\mathrm{H}_{2} \mathrm{O} / \mathrm{H}_{3} \mathrm{PO}_{4}, 900: 100: 1$ ) at a flow rate of $1.0 \mathrm{ml} / \mathrm{min}$ and a $10-80 \%$ gradient of $\mathrm{B} 1$ over 20 min. The HPLC column eluates were monitored by their absorbance at $220 \mathrm{~nm}$. Molecular weight and purity of synthesized peptides were checked by MALDI-TOF mass spectrometry (Bruker Daltonics, Germany) or electron spray LC/MS-2010 (Shimadzu Co., Kyoto, Japan).

Parasite. Schistosoma mansoni (BH strain Belo Horizonte, Brazil) worms have been maintained in Biomphalaria glabrata snails and hamsters as hosts at the Parasitology Laboratory (Instituto Butantan, São Paulo, Brazil). Female hamsters, weighing 20 to 22 g, were infected by subcutaneous injection of 150 cercariae. After 7 weeks, adults $S$. mansoni specimens were recovered from hamster by perfusion with RPMI 1640 medium supplemented with heparin [51].

Ethics statement. This study was approved by the Institutional Review Board of Instituto Butantan (approval number: 415/07). All animals were handled in strict accordance with good animal practice as defined by the Animals Use Ethics Committee of the University of São Paulo (USP, São Paulo, Brazil) and the Butantan Institute (São Paulo, Brazil); the study was conducted adhering to the guidelines of the institution for animal husbandry. 
In vitro studies. Schistosoma mansoni worms harvested from hamster were washed in RPMI 1640 medium (Gibco) supplemented with $200 \mu \mathrm{g} / \mathrm{ml}$ of streptomycin, $200 \mathrm{IU} / \mathrm{ml}$ of penicillin (Invitrogen), and Hepes $25 \mathrm{mM}$. Adult worm pairs (male and female) were incubated in a 24-well culture plate (Techno Plastic Products, TPP) containing $2 \mathrm{ml}$ of the same medium supplemented with $10 \%$ heat-inactivated calf serum at $37{ }^{\circ} \mathrm{C}$ in $5 \% \mathrm{CO}_{2}$ atmosphere [52]. After 1 to $2 \mathrm{~h}$, dermaseptin was added to the culture, yielding a final drug concentration of 1 to $200 \mu \mathrm{g} / \mathrm{ml}$ [53]. Dermaseptin was dispensed from a stock solution (2000 $\mu \mathrm{g} / \mathrm{ml}$ ) in RPMI 1640. Worm motor activity, egg output (oviposition), tegumental alterations, and survival of parasites were monitored on daily basis for 5 days using an inverted microscope and a stereomicroscope (SMZ 1000, Nikon) [52]. All experiments were carried out in triplicates and were repeated at least three times.

Tegumental changes. The quantification of the number of tubercles was performed using a confocal microscope. After the established times, or in occurrence of death, the parasites were fixed in Formalin-acetic-alcohol solution (FAA) and analyzed under a confocal microscope (Laser Scanning Microscopy, LSM 510 META, Zeiss) at $488 \mathrm{~nm}$ (exciting) and $505 \mathrm{~nm}$ (emission) as described [54]. A minimum of three areas of the tegument of each parasite were assessed. The numbers of tubercles were counted in $20,000 \mu \mathrm{m}^{2}$ of area calculated with the Zeiss LSM Image Browser software.

Statistical analysis. Statistical tests were performed with the GRAPHPAD PRISM (version 4.0) software. Significant differences between means were determined by two-tailed Student's $t$-test. 


\section{REFERENCES}

[1] C.H. King, K. Dickman, D.J. Tisch, Lancet 2005, 365, 1561.

[2] P. Steinmann, J. Keiser, R. Bos, M. Tanner, J. Utzinger, Lancet Infect. Dis. 2006, 6, 411.

[3] B. Gryseels, K. Polman, J. Clerinx, L. Kestens, Lancet 2006, 368, 1106.

[4] M. Ismail, S. Botros, A. Metwally, S. William, A. Farghally, L.F. Tao, T.A. Day, J.L. Bennett, Am. J. Trop. Med. Hyg. 1999, 60, 932.

[5] Y.S. Liang, G.C. Coles, M.J. Doenhoff, V.R. Southgate, Int. J. Parasitol. 2001, 31, 1227.

[6] C.R. Caffrey, Curr. Opin. Chem. Biol. 2007, 11, 433.

[7] B. Ramirez, Q. Bickle, F. Yousif, F. Fakorede, M.A. Mouries, S. Nwaka, Expert Opin. Drug Discov. 2007, 2, 53.

[8] M. Doenhoff, D. Cioli, J. Utzinger, Curr. Opin. Infect. Dis. 2008, 21, 659.

[9] R.E.W. Hancock, D.S. Chapple, Antimicrob. Agents Chemother. 1999, 43, 1317.

[10] K.L. Brown, R.E. Hancock, Curr. Opin. Immunol. 2006, 18, 24.

[11] R.M. Epand, H.J. Vogel, Biochim. Biophys. Acta 1999, 1462, 11.

[12] M. Zasloff, Nature 2002, 415, 389. 
[13] Y. Park, K.S. Hahm, Biochem. Mol. Biol. 2005, 38, 507.

[14] P. Nicolas, C.E. Amri, Biochim. Biophys. Acta 2009, 1788, 1537.

[15] M. Zasloff, Proc. Natl. Acad. Sci. USA. 1987, 84, 5449.

[16] G.D. Brand, J.R. Leite, L.P. Silva, S. Albuquerque, M.V. Prates, R.B. Azevedo, V. Carregaro, J.S. Silva, V.C. Sá, R.A. Brandão, C. Jr. Bloch, J. Biol. Chem. 2002, 277, 49332.

[17] A.C. Rinaldi, Curr. Opin. Chem. Biol. 2002, 6, 799.

[18] A. Zairi, F. Tangy, K. Bouassida, K. Hani, J. Biomed. Biotechnol. 2009, 2009, 452567.

[19] A. Mor, K. Hani, P. Nicolas, J. Biol. Chem. 1994, 269, 31635.

[20] G.D. Brand, J.R. Leite, S.M. de Sá Mandel, D.A. Mesquita, L.P. Silva, M.V. Prates, E.A. Barbosa, F. Vinecky, G.R. Martins, J.H. Galasso, S.A. Kuckelhaus, R.N. Sampaio, J.R. Furtado Jr, A.C. Andrade, C. Jr. Bloch, Biochem. Biophys. Res. Commun. 2006, 347, 739.

[21] O. Lequin, A. Ladram, L. Chabbert, F. Bruston, O. Convert, D. Vanhoye, G. Chassaing, P. Nicolas, M. Amiche, Biochemistry 2006, 45, 468.

[22] P.J. Coote, C.D. Holyoak, D. Bracey, D.P. Ferdinando, J.A. Pearce, Antimicrob. Agents Chemother. 1998, 42, 2160. 
[23] A.J. De Lucca, J.M. Bland, T.J. Jacks, C. Grimm, T.J. Walsh, Med. Micol. 1998, 36, 291.

[24] J.R. Leite, G.D. Brand, L.P. Silva, S.A. Kückelhaus, W.R. Bento, A.L. Araújo, G.R. Martins, A.M. Lazzari, C. Jr. Bloch, Comp. Biochem. Physiol. A. Mol. Integr. Physiol. 2008, $151,336$.

[25] A. Belaid, M. Aouni, R. Khelifa, A. Trabelsi, M. Jemmali, K. Hani, J. Med. Virol. 2002, $66,229$.

[26] V.G. Chinchar, L. Bryan, U. Silphadaung, E. Noga, D. Wade, L. Rollins-Smith, Virology 2004, 323, 268.

[27] C. Lorin, H. Saidi, A. Belaid, A. Zairi, F. Baleux, H. Hocini, L. Bélec, K. Hani, F. Tangy, Virology 2005, 334, 264.

[28] M.F. Zampa, I.M. Araújo, V. Costa, C.H. Nery Costa, J.R.Jr. Santos, V. Zucolotto, C. Eiras, J.R. Leite, Nanomedicine, 2009, 5, 352.

[29] A. Dagan, L. Efron, L. Gaidukov, A. Mor, H. Ginsburg, Antimicrob. Agents Chemother. 2002, 46, 1059.

[30] R. Feder, R. Nehushtai, A. Mor, Peptides 2001, 22, 1683.

[31] J. Keiser, Parasitology 2010, 137, 589. 
[32] L. Pica-Mattoccia, D. Cioli, Int. J. Parasitol. 2004, 34, 527.

[33] L. Sanderson, A. Bartlett, P.J. Whitfield, J. Helminthol. 2002, 76, 241.

[34] M.L. De Oliveira Penido, P.M. Zech Coelho, R.T. de Mello, D. Piló-Veloso, M.C. de Oliveira, J.R. Kusel, D.L. Nelson, Acta Trop. 2008, 108, 249.

[35] S.C. De Araújo, A.C. de Mattos, H.F. Teixeira, P.M. Coelho, D.L. Nelson, M.C. de Oliveira, Int. J. Pharm. 2007, 337, 307.

[36] Y. Mitsui, M. Miura, Y. Aoki, J. Helminthol. 2009, 83, 7.

[37] L.G. Magalhães, C.B. Machado, E.R. Morais, E.B. Moreira, C.S. Soares, S.H. da Silva, A.A. da Silva Filho, Parasitol. Res. 2009, 104, 1197.

[38] L.G. Magalhães, G.J. Kapadia, L.R. da Silva Tonuci, S.C. Caixeta, N.A. Parreira, V. Rodrigues, A.A. da Silva Filho, Parasitol. Res. 2010, 106, 395.

[39] A.M. Mohamed, N.M. Metwally, S.S. Mahmoud, Mem. Inst. Oswaldo Cruz 2005, 100, 205.

[40] X. Shuhua, S. Binggui, J. Chollet, M. Tanner, Acta Trop. 2000, 76, 107. 
[41] S. William, S. Botros, M. Ismail, A. Farghally, T.A. Day, J.L. Bennett, Parasitology 2001, 122, 63.

[42] T. Manneck, Y. Haggenmüller, J. Keiser, Parasitolology 2010, 137, 85.

[43] X. Shuhua, S. Binggui, J. Chollet, J. Utzinger, M. Tanner, J. Parasitol. 2000, 86, 1125.

[44] H.W. Huang, Biochemistry 2000, 39, 8347.

[45] J.W. Daly, J. Caceres, R.W. Moni, F. Gusovsky, M. Jr. Moos, K.B. Seamon, K. Milton, C.W. Myers, Proc. Natl. Acad. Sci. USA. 1992, 89, 10960.

[46] A. Mor, V.H. Nguyen, A. Delfour, D. Migliore-Samour, P. Nicolas, Biochemistry 1991, 30,8824 .

[47] A. Mor, P. Nicolas, Eur. J. Biochem. 1994, 219, 145.

[48] P. La Rocca, Y. Shai, M.S. Sansom. Biophys. Chem. 1999, 76, 145.

[49] S.H. White, W.C. Wimley, Biochim. Biophys. Acta 1998, 1376, 339.

[50] E. Atherton, R.C. Sheppard, 'Solid phase peptide synthesis: a practical approach, Oxford, England: IRL Press, 1989.

[51] S.R. Smithers, R.J. Terry, Parasitology 1965, 55, 695. 
[52] S.H. Xiao, J. Keiser, J. Chollet, J. Utzinger, Y. Dong, Y. Endriss, J.L. Vennerstrom, M. Tanner, Antimicrob. Agents Chemother. 2007, 51, 1440.

[53] S.H. Xiao, B.A. Catto, Antimicrob. Agents Chemother. 1989, 33, 1557.

[54] J. Moraes, M.P. Silva, F.P. Ohlweiler, T. Kawano, Rev. Inst. Med. Trop. Sao Paulo 2009, $51,77$. 
Table 1. In vitro effects of dermaseptin 01 on 49-day-old adult Schistosoma mansoni

\begin{tabular}{|c|c|c|c|c|c|c|}
\hline \multirow[t]{2}{*}{$\begin{array}{c}\text { Dermaseptin } \\
01(\mu \mathrm{g} / \mathrm{ml})\end{array}$} & \multirow{2}{*}{$\begin{array}{l}\text { Incubation } \\
\text { of period } \\
\text { (h) }\end{array}$} & \multirow{2}{*}{$\begin{array}{c}\text { Dead } \\
\text { worms } \\
\left.(\%)^{\mathrm{a}}\right)\end{array}$} & \multicolumn{2}{|c|}{$\begin{array}{l}\text { Motor activity } \\
\text { reduction } \\
\left.(\%)^{\mathrm{a}}\right)\end{array}$} & \multicolumn{2}{|c|}{$\begin{array}{c}\text { Worms with } \\
\text { tegumental } \\
\left.\text { alterations }(\%)^{\mathrm{a}}\right)\end{array}$} \\
\hline & & & Slight & Significant & Partial & Extensive \\
\hline \multirow[t]{5}{*}{0} & 24 & 0 & 0 & 0 & 0 & 0 \\
\hline & 48 & 0 & 0 & 0 & 0 & 0 \\
\hline & 72 & 0 & 0 & 0 & 0 & 0 \\
\hline & 96 & 0 & 0 & 0 & 0 & 0 \\
\hline & 120 & 0 & 0 & 0 & 0 & 0 \\
\hline \multirow[t]{5}{*}{25} & 24 & 0 & 0 & 0 & 0 & 0 \\
\hline & 48 & 0 & 0 & 0 & 0 & 0 \\
\hline & 72 & 0 & 0 & 0 & 0 & 0 \\
\hline & 96 & 0 & 20 & 0 & 0 & 0 \\
\hline & 120 & 0 & 60 & 0 & 0 & 0 \\
\hline \multirow[t]{5}{*}{50} & 24 & 0 & 0 & 0 & 0 & 0 \\
\hline & 48 & 0 & 50 & 0 & 0 & 0 \\
\hline & 72 & 50 & 50 & 50 & 0 & 0 \\
\hline & 96 & 60 & 40 & 60 & 0 & 0 \\
\hline & 120 & 100 & 0 & 100 & 20 & 0 \\
\hline \multirow[t]{5}{*}{100} & 24 & 0 & 60 & 40 & 100 & 0 \\
\hline & 48 & 100 & 0 & 100 & 0 & 100 \\
\hline & 72 & 100 & 0 & 100 & 0 & 100 \\
\hline & 96 & 100 & 0 & 100 & 0 & 100 \\
\hline & 120 & 100 & 0 & 100 & 0 & 100 \\
\hline \multirow[t]{5}{*}{150} & 24 & 40 & 50 & 50 & 0 & 100 \\
\hline & 48 & 100 & 0 & 100 & 0 & 100 \\
\hline & 72 & 100 & 0 & 100 & 0 & 100 \\
\hline & 96 & 100 & 0 & 100 & 0 & 100 \\
\hline & 120 & 100 & 0 & 100 & 0 & 100 \\
\hline \multirow[t]{5}{*}{200} & 24 & 100 & 0 & 100 & 0 & 100 \\
\hline & 48 & 100 & 0 & 100 & 0 & 100 \\
\hline & 72 & 100 & 0 & 100 & 0 & 100 \\
\hline & 96 & 100 & 0 & 100 & 0 & 100 \\
\hline & 120 & 100 & 0 & 100 & 0 & 100 \\
\hline
\end{tabular}

a) Percentages relative to the 20 worms investigated. Pairs of adult worms were incubated in 24-well culture plate containing RPMI 1640 medium and treated with DS 01 at different concentration during time periods indicated. Worm motor activity and survival of the parasites were monitored under a stereomicroscope. Tegumental alterations were monitored under an inverted microscope and a confocal microscope.

\section{Legends to Figures}


Figure 1. Biological source and bioactive peptide. (A) Adult male of Phyllomedusa oreades (Spix, 1824). (B) Helix-Wheel plots of the antimicrobial peptide (dermaseptin 01) showing the amphiphilic character of the molecule. The residues represented by pentagons, diamonds, circles, and triangles are positively charged, aliphatic, polar uncharged and negatively charged side chains, respectively. The amino acid side chains are projected down the axis of the alpha helix (orthogonal to the plane of the page). As an ideal alpha helix consists of 3.6 residues per complete turn, the angle between two residues is chosen to be 100 degrees.

Figure 2. In vitro effect of dermaseptin 01 on the survival of Schistosoma mansoni. Pairs of adult worms, males (closed bars) and females (open bars), were incubated in a 24-well culture plate containing RPMI 1640 medium and treated with dermaseptin 01 at different concentration during time periods indicated. Mortality data are presented from ten worm couples.

Figure 3. In vitro effect of dermaseptin 01 on egg laying by Schistosoma mansoni. Adult worm couples were incubated in a 24-well culture plate containing RPMI 1640 medium and treated with dermaseptin 01 at different concentration. At the time periods indicated, the cumulative number of eggs by each worm couple was assessed and scored using an inverted microscope. Values are means $\pm \mathrm{SD}$ (bars) of ten worm couples.

Figure 4. Effect of dermaseptin 01 on the tegument of Schistosoma mansoni. Pairs of adult worms were incubated in a 24-well culture plate containing RPMI 1640 medium and treated with dermaseptin 01 at different concentration. After 48 hours of incubation with peptide, adult male worms were fixed in FAA solution and fluorescent images were obtained using 
confocal microscopy. (A and B) Control. (C and D) Dermaseptin $50 \mu \mathrm{g} / \mathrm{ml}$. (E and F)

Dermaseptin $100 \mu \mathrm{g} / \mathrm{ml}$. (G and H) Dermaseptin $150 \mu \mathrm{g} / \mathrm{ml}$. (I and J) Dermaseptin $200 \mu \mathrm{g} / \mathrm{ml}$. Left images $($ bars $=200 \mu \mathrm{m})$. High images showing higher magnification of the tegumental surface of male worms (bars $=50 \mu \mathrm{m}$ ). The images were analyzed with the Zeiss LSM Image Browser software.

Figure 5. Effect of dermaseptin 01 on tubercles of Schistosoma mansoni male worms. Pairs of adult worms were incubated in a 24-well culture plate containing RPMI 1640 medium and treated with dermaseptin 01 at different concentration. After occurrence of death, adult male worms were fixed in FAA solution. The quantification of the number of tubercles was performed using confocal microscopy. Indicated are numbers of intact tubercles and these numbers were measured in a $20,000 \mu \mathrm{m}^{2}$ of area calculated with the Zeiss LSM Image Browser software. A minimum of three tegument areas of each parasite were assessed. Values are means $\pm \mathrm{SD}$ (bars) of ten adult male worms. 
Figure 1

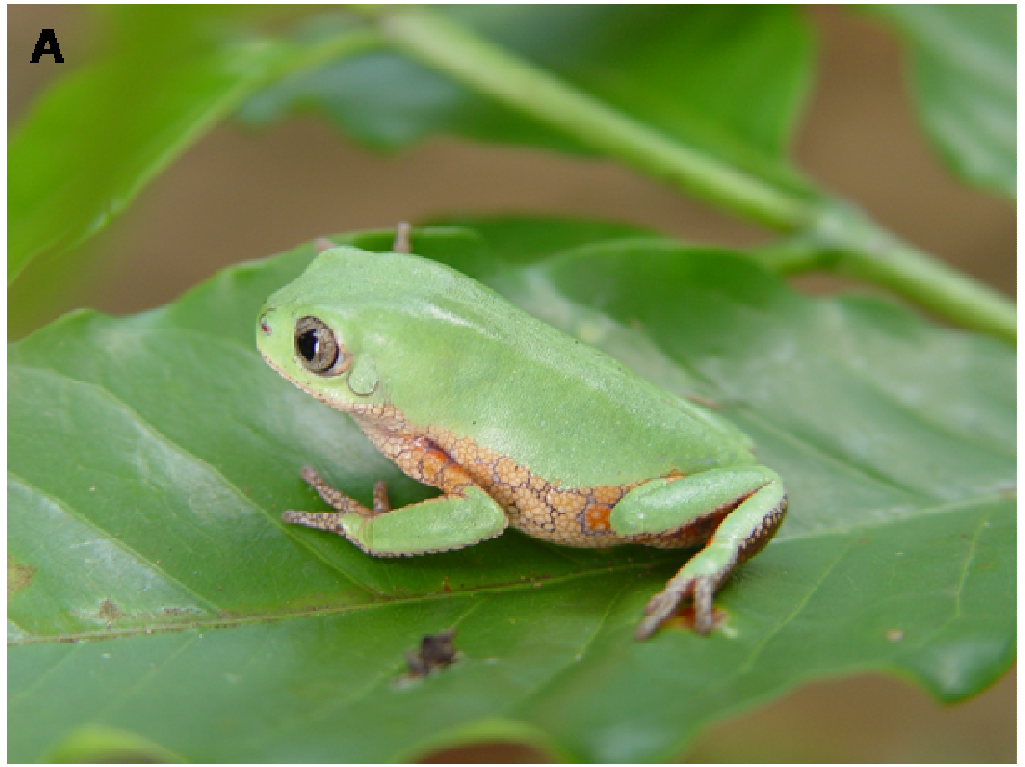

B GLWSTIKQKGKEAAIAAAKAAGQAALGAL-NH ${ }_{2}$

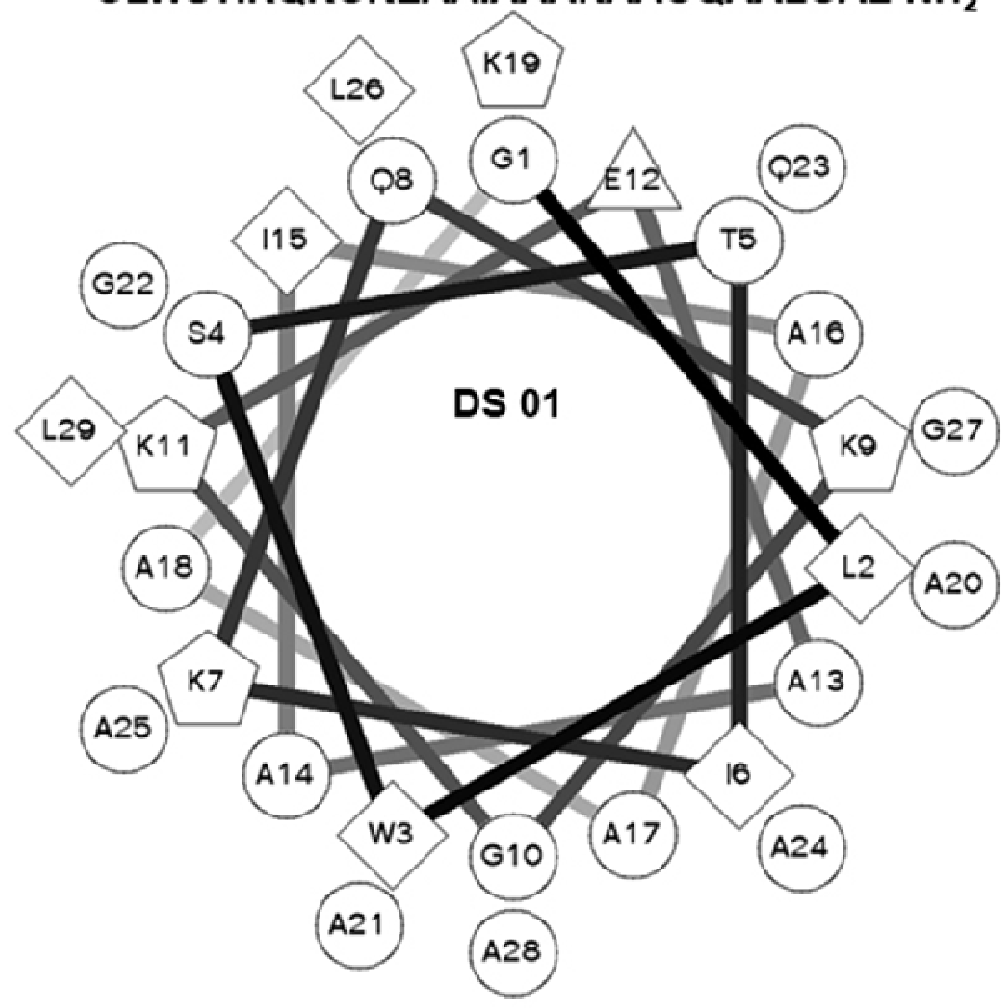


Figure 2
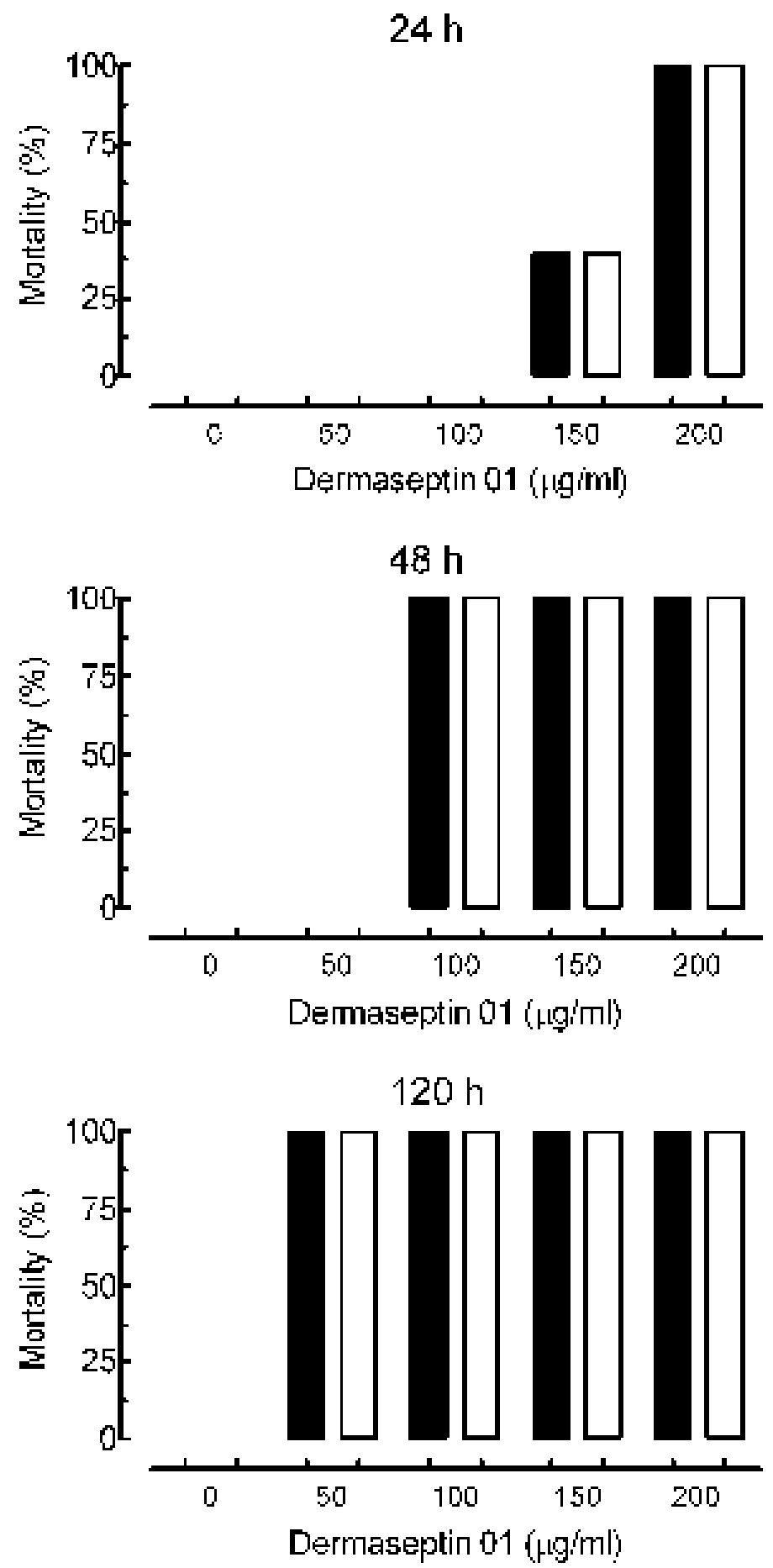
Figure 3

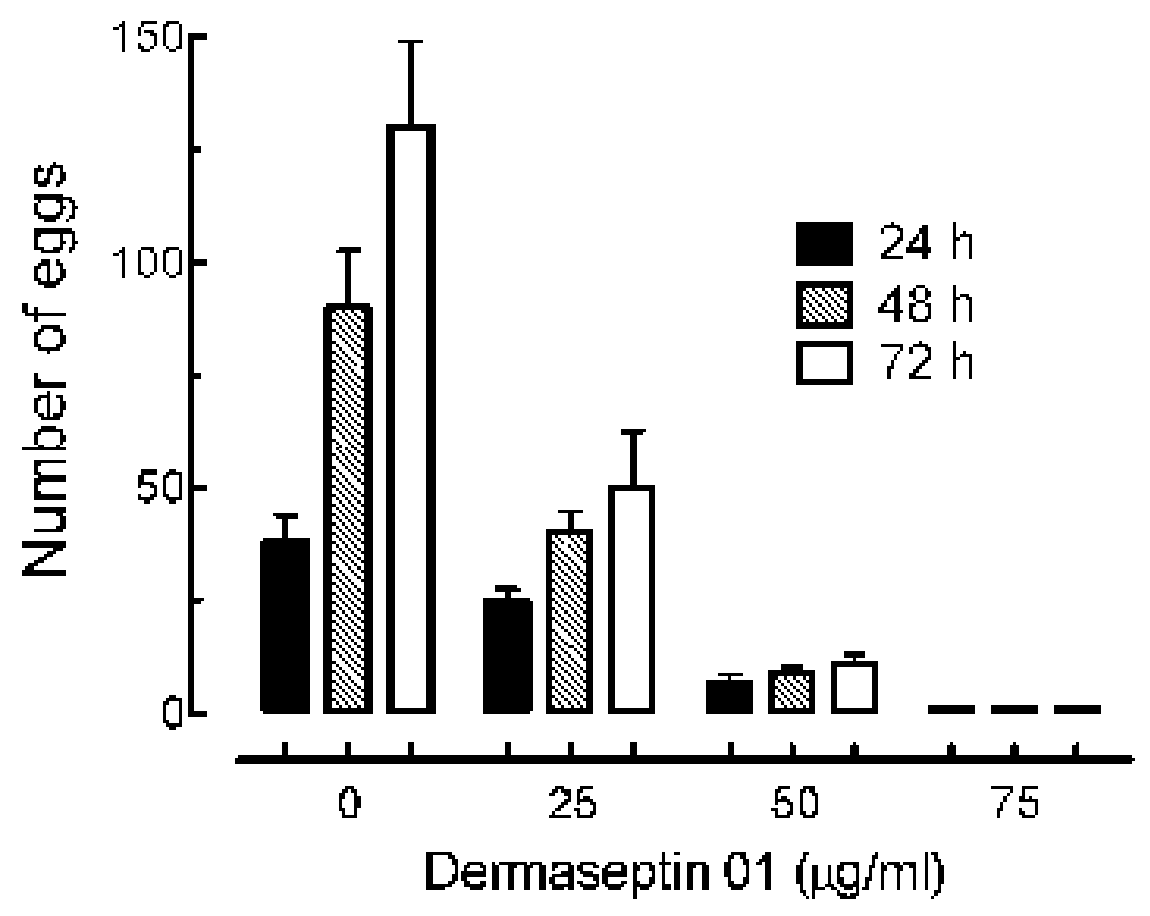


Figure 4

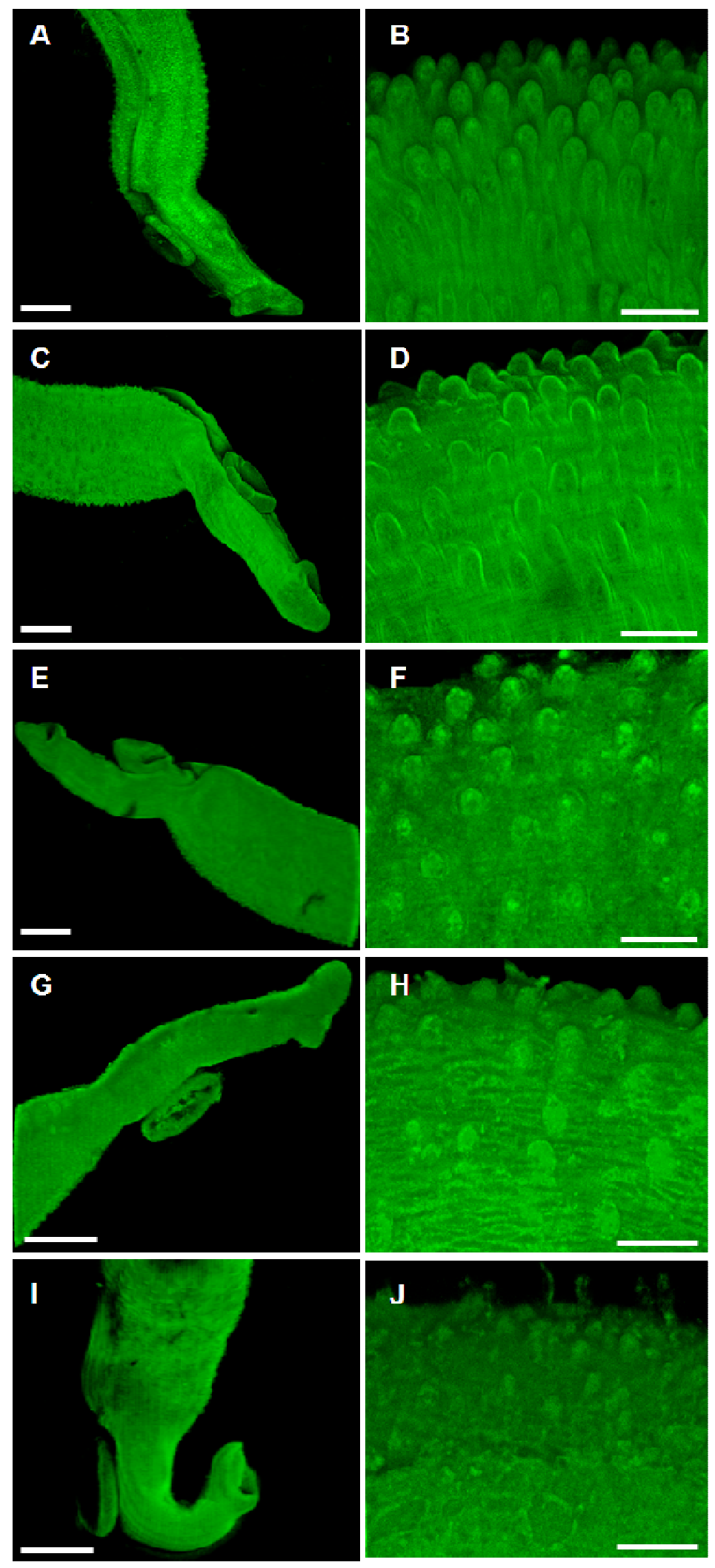

Figure 5 


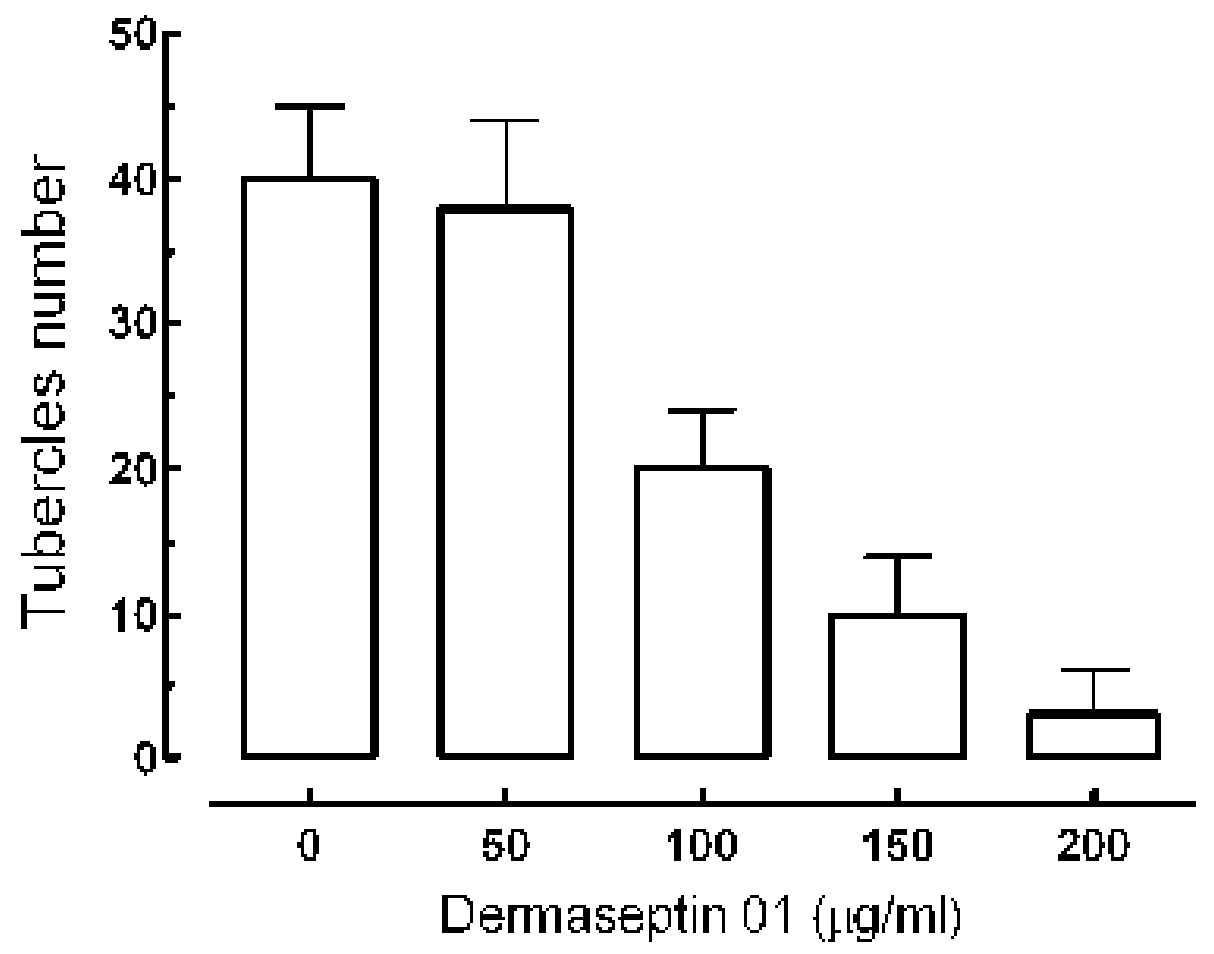




\section{ANEXO - C}

Evaluation of the in vitro activity of epiisopiloturin alkaloid isolated from jaborandi (Pilocarpus microphyllus Stapf ex Holm.; Rutaceae) against Schistosoma mansoni and Leishmania amazonensis 


\section{Evaluation of the in vitro activity of Epiisopiloturin Alkaloid isolated from Jaborandi (Pilocarpus microphyllus Stapf ex Holm.; Rutaceae) against Schistosoma mansoni and Leishmania amazonensis}

Leiz Maria Costa Veras Miura ${ }^{1,2}$, David Fernandes Lima ${ }^{3,4}$, Josué de Moraes ${ }^{5}$, Sabrina Maria Portela Carneiro $^{6,7}$, Guilherme Dotto Brand ${ }^{1,8}$, Toshie Kawano ${ }^{5}$, Fernando Aécio de Amorim Carvalho $^{6}$, Carlos Bloch Júnior ${ }^{8}$, Maria do Carmo de Souza Batista ${ }^{9}$, José Roberto de Souza Almeida Leite ${ }^{1, *}$.

${ }^{1}$ Núcleo de Pesquisa em Biodiversidade e Biotecnologia, Biotec, Campus Ministro Reis Velloso, CMRV, Universidade Federal do Piauí, UFPI, Parnaíba, Piauí, PI, Brasil;

${ }^{2}$ Programa de Mestrado em Ciência Animal, Centro de Ciências Agrárias, CCA, Universidade Federal do Piauí, UFPI, Teresina, Piauí, PI, Brasil;

${ }^{3}$ VEGEFLORA Extrações do Nordeste, Parnaíba, Piauí, PI, Brasil;

${ }^{4}$ Programa de mestrado em Farmacologia, Núcleo de Pesquisa em Plantas Medicinais, Universidade Federal do Piauí, UFPI, Teresina, PI, Brasil;

${ }^{5}$ Laboratório de Parasitologia, Instituto Butantan, São Paulo, SP, Brasil;

${ }^{6}$ Núcleo de Pesquisa em Plantas Medicinais, Universidade Federal do Piauí, UFPI, Teresina, PI, Brasil;

${ }^{7}$ Programa de doutorado Rede Biotecnologia do Nordeste, Fortaleza, Ceará, CE, Brasil;

${ }^{8}$ Laboratório de Espectrometria de Massa, LEM, Embrapa Recursos Genéticos e Biotecnologia, Brasília, DF, Brasil;

${ }^{9}$ Laboratório de Morfofisiologia Veterinária, Centro de Ciências Agrárias, CCA, Universidade Federal do Piauí, UFPI, Teresina, PI, Brasil.

${ }^{*}$ Corresponding Author: José Roberto S. A. Leite

Phone number: +55 $863315-5525$

e-mail: jrleite@ufpi.br and jrsaleite@gmail.com

Núcleo de Pesquisa em Biodiversidade e Biotecnologia, Biotec, Campus Ministro Reis Velloso, CMRV, Universidade Federal do Piauí, UFPI, Parnaíba, Piauí, PI, Brasil. 


\begin{abstract}
Neglected tropical diseases such as schistosomiasis and leishmaniasis continue to cause significant morbidity and mortality in the developing countries, reinforcing the demand for the development of novel drugs. Here we report the schistosomicidial and leishmanicidial activities of epiisopiloturin, an imidazolic alkaloid extracted from the leaves of Pilocarpus microphyllus, known as jaborandi. This compound was isolated by high performance liquid chromatography (HPLC) and had its chemical structure confirmed by ion-trap mass spectrometry. It had significant in vitro activity against adult Schistosoma mansoni and Leishmania amazonensis amastigotes and no detectable cytotoxicity to peritoneal macrophage cells. It is the first time that epiisopiloturin is reported as a promising schistosomicidal and leishmanicidal agent.
\end{abstract}

Key words: Epiisopiloturin; Alkaloid; Leishmania amazonensis; Schistosoma mansoni.

\title{
1. Introduction
}

Pilocarpus microphyllus (Rutaceae family) is originally from the Amazon and Cerrado regions of Brazil where it is known as jaborandi. This plant is a rich source of imidazole alkaloids such as pilocarpine, isopilocarpine (the $\mathrm{C}[3]$-epimer of pilocarpine), pilosinine $\quad(2 \mathrm{R}, 3 \mathrm{R}, 6 \mathrm{~S}), \quad$ isopilosine $\quad(2 \mathrm{~S}, 3 \mathrm{R}, 6 \mathrm{R})$, epiisopilosine $\quad(2 \mathrm{~S}, 3 \mathrm{R}, 6 \mathrm{~S})$ and epiisopiloturin (Sawaya et al., 2008; Voigtlander et al., 1978). Pilocarpine is the best known of the jaborandi alkaloids and the only one with commercial value, used both as a miotic and diaphoretic agent due to its action as a peripheral stimulant of the parasympathetic system (Davies et al., 2009; Abreu et al., 2005; Sawaya et al., 2008). 
However, from this set of structurally related molecules, only pilocarpine has a defined biological activity (Davies et al., 2009; Voigtlander et al., 1978). Imidazole alkaloids display a wide range of pharmacological activities (Barradas et al., 2008). They have been used as antiparasitic, antibacterial, antimicobacterial, antitumoral, antioxidant and antifungal agents (Hadj-Esfandiari et al., 2007; Khabnadideh et al., 2003, Mallia et al., 2006; Olender et al., 2009; Walczak et al., 2004;).

This indicates that the alkaloid extract of jaborandi leaves harbor a still unexplored set of molecules with potential application in human health, such as putative antimicrobial compounds that can be further developed in alternative treatments for infectious diseases (Camargo, 2008). There is an increasing demand for novel drugs in developing countries, especially for the treatment of "neglected tropical diseases" (NTDs), known to affect more than 1 billion people, about one-sixth of the world's population, are infected with one or more of 13 NTDs (WHO, 2009). NTDs have a terrible impact on health, impede child growth and development, harm pregnant women, and often cause longterm debilitating illnesses. They cause an extraordinary amount of ill health, disability and disfigurement, and are often deadly (WHO, 2009).

Leishmaniasis is a neglected tropical parasitic disease characterized by the infection of macrophages by obligate intracellular parasites of the genus Leishmania. It has been considered as a major health problem worldwide, especially in developing nations (Rocha et al., 2005). Globally, there are an estimated 1.5-2 million new cases and 70 000 deaths each year, and 350 million people are at risk of infection and disease. Morbidity and mortality because of the leishmaniases cause an estimated 2-4 million disability-adjusted life-years (Murray, 2005).

The inexistence of a vaccine places an urgent demand for more effective drugs to replace/supplement those in current use. Most of the clinically used drugs for the 
treatment of leishmaniasis are based on pentavalent antimony compounds and were developed before 1959 (Dunning, 2009). Generally, these drugs have one or more limitations, like unaffordable cost, difficulty in administration, toxicity or more importantly the development of resistant parasites. Alternative drugs, such as amphotericin B and pentamidine, also have unpleasant side effects (Kedzierski et al., 2009).

Schistosomiasis also represents a serious health problem in tropical and subtropical countries. An estimated total of 207 million people are infected worldwide, while 779 million people remain under infection risk (Steinmann et al., 2006). The current treatment is based on the use of praziquantel (PZQ), a non-expensive anthelminthic drug highly effective against all schistosomes species those infecting humans. However, the parasite treatment based on the use of only one drug causes serious concerns regarding development resistance. Therefore, the development of novel and effective schistosomicidal compounds are highly desirable (Caffrey, 2007; Doenhoff et al., 2008).

The development of resistance to these alkaloids and toxicity to the host have been reported (Melo et al., 2003). Plant extracts or plant-derived compounds are likely to provide a valuable source of novel medicinal agents (Kayser and Kiderlen, 2001).

The present work describes the purification, characterization, and potential application of the alkaloid epiisopiloturin, extracted from jaborandi leaves, as a leishmanicidal and schistosomicidal agent.

\section{Material and methods}

\subsection{Plant material}


The plant material was collected from a specimen of Pilocarpus microphyllus growing under greenhouse conditions at the Matias Olímpio (Piauí, Brazil), and it was identified by Ivanilza Moreira de Andrade, Ph. D. The voucher specimen was deposited at the Graziella Barroso Herbarium of the Teresina, Piauí and Brazil (TEPB 27.152 Tomber number).

\subsection{Extraction and purification of alkaloid epiisopiloturin.}

The alkaloid epiisopiloturin was purified from the biomass generated by the production of pilocarpine held by VEGEFLORA Extrações do Nordeste Ltda. The biomass was subjected to an extraction process for alkaloids based on acidification and filtration of industrial waste followed by the alkalinization and filtering of the solution to obtain concentrated epiisopiloturin (Costa, 1999). Solutions were filtered with $0.45 \mu \mathrm{m}$ pore membranes and injected into a high performance liquid chromatographer, HPLC (Shimadzu Prominence, AUTOSAMPLER SIL-10AF, CTO-20A, LC-6AD, CBM-20A, SPD-20A). The column used was Merck LiChrospher 60 RP Select B (5 $\mu \mathrm{m})$ and mobile phase consisted of $5 \%(\mathrm{v} / \mathrm{v})$ potassium phosphate at $\mathrm{pH} 2.5$ at a flow rate of $1 \mathrm{~mL} / \mathrm{min}$ at

$50^{\circ} \mathrm{C}$. HPLC detector was set to $216 \mathrm{~nm}$. Mass spectrometry was used to evaluate the purity and monoisotopic molecular mass of epiisopiloturin (HCT Ultra PTM ETD II from Bruker Daltonics (Bremen, Germany). Mass spectra were acquired in a mass range of $\mathrm{m} / \mathrm{z} 70$ to $300 \mathrm{Da}$. MS2 was carried out in manual mode with fragmentation of the precursor ion by CID using $\mathrm{He}$ as the collision gas. Precursor ions were selected within an isolation width of $2 \mathrm{u}$ and scans were accumulated with variable RF signal amplitudes. The $\mathrm{m} / \mathrm{z}$ scale of the mass spectrum was calibrated using the external calibration standard G2421A electrospray "tuning mix” from Agilent Technologies (Santa Rosa, CA, USA). 


\subsection{Anti-leishmania assay}

\subsubsection{Leishmania promastigotes}

The IFLA/BR/67/PH-8 strain of Leishmania amazonensis, originally isolated from a human case of diffuse cutaneous leishmaniasis, was used in the present study. This strain has been maintained in Warren's medium (brain-heart infusion plus haemin and folic acid) supplemented with 10\% heat inactivated fetal bovine serum (FBS) (Gibco Invitrogen Corporation, New York, U.S.A) at $28{ }^{\circ} \mathrm{C}$ in a tissue flask, as previously described by Lima et al., 2000.

Leishmania amazonensis IFLA/BR/67/PH-8 was cultivated in 96 well microplates in the presence of serial dilutions (ranging from 2 to $128 \mu \mathrm{g} / \mathrm{mL}$ ) of the epiisopiloturin alkaloid diluted in Schneider medium (Sigma MRC) the addition of $2 \%$ dimethyl sulfoxide (DMSO). As negative and positive controls, respectively, were used DMSO at $2 \%$ and amphotericin $\mathrm{B}$ at $3 \%$ in culture medium. The concentration of promastigotes placed on each well was 106 cells. Microplates were incubated in the Biochemical Oxygen Demand (B.O.D) at $26{ }^{\circ} \mathrm{C}$ and cell counts were performed after 24 and 48 hours in hemocytometer (Neubauer, improved double, Superior Ltd, Germany).

\subsubsection{Peritoneal macrophages.}

Macrophages were removed from the peritoneum of Swiss female mice, after the inoculation of $10 \mathrm{~mL}$ sterile Phosphate Buffered Saline (PBS) followed by abdominal massage. Macrophages were collected and washed three times with sterile PBS, centrifuged at $1.0 \times 10^{3} \mathrm{rpm}$ for ten minutes and then resuspended in culture medium (RPMI 1640 from Sigma). Subsequently, $5 \times 10^{5}$ cells were seeded to adhere to a 24 wells culture plate and left overnight at $5 \% \mathrm{CO} 2,37{ }^{\circ} \mathrm{C}$, followed by the addition of $500 \mu \mathrm{L}$ of RPMI 1640 on each well. Roughly $5 \times 10^{6}$ promastigotes were added to each well, resulting in 1:10 macrophages/leishmania and incubated for 4 hours at $37^{\circ} \mathrm{C}$ in $5 \% \mathrm{CO}_{2}$. 
Wells were then washed with PBS to remove the free parasites. Epiisopiloturin in RPMI medium was added to wells containing infected macrophages at 128,16 and $2 \mu \mathrm{g} / \mathrm{mL}$ in triplicate and incubated for 48 hours. After incubation, the and $2 \mu \mathrm{g} / \mathrm{mL}$ in triplicate and incubated for 48 hours. After incubation, the samples were aspirated, washed in PBS and the cover slip were stained by panoptic method (Laborclin). After the treatment with epiisopiloturin, the number of infected macrophages and the number of parasites per macrophage were calculated, using a sample size of 100 macrophages. The total number of associated amastigotes (association index) and total number of internalised amastigotes (phagocytic index) by 100 macrophages were quantified. The percentage of associated amastigotes that are also internalized was determined (Escaron et al., 2007).

\subsection{Citotoxic effects of epiisopiloturin to peritoneal cells.}

The toxicity of epiisopiloturin to mammalian cells was estimated using peritoneal mice cells, predominantly macrophages. Cells were obtained by washing the peritoneal cavity of mice with $10 \mathrm{~mL}$ cold sterile PBS at $\mathrm{pH} 7.2$ followed by centrifugation at 1.0 x $103 \mathrm{rpm}$ at $4^{\circ} \mathrm{C}$ for 10 minutes and quantification with trypan blue in PBS pH 7.2 in hemocytometer (viability above 95\%). Viable cells $(2.5 \times 104)$ were cultured in 96 well microplates for 1 hour with different concentrations of epiisopiloturin (from 1 to 128 $\mu \mathrm{g} / \mathrm{mL})$ at $37^{\circ} \mathrm{C}$ and $5 \% \mathrm{CO} 2$. Cell viability was assessed using the method of Mosmann (1983), which is based on the capacity of mitochondrial dehydrogenase enzyme from viable cells to cleave the pale yellow tetrazolium rings of MTT [3-(4.5-dimethylthiazol-2-yl)2.5-difeniltetrazolio bromide] (Sigma-Aldrich, St Louis, USA) producing dark blue crystals. The release of crystals was obtained by adding $50 \mu \mathrm{L} 10 \%$ sodium dodecyl 
sulfate (Sigma-Aldrich, St Louis, USA) and quantification was carried out by colorimetric spectrophotometry assay at $550 \mathrm{~nm}$.

\subsection{Anti-helminthes assay.}

\subsubsection{Parasite.}

Schistosoma mansoni (BH strain Belo Horizonte, Brazil) worms have been maintained in Biomphalaria glabrata snails and Mesocricetus auratus hamsters hosts at the Parasitology Laboratory (Butantan Institute, São Paulo, Brazil).. Female hamsters, weighting 20 to $22 \mathrm{~g}$, were infected by subcutaneous injection of 150 cercariae. After 9 weeks, adult S. mansoni specimens were recovered from the hamsters by perfusion with the RPMI 1640 medium supplemented with heparin (Smithers and Terry, 1965). The

experimental protocols were authorized by Ethical Committee for Animal Experimentation of the University of São Paulo (USP, São Paulo, Brazil) and the Butantan Institute (São Paulo, Brazil).

\subsubsection{In vitro studies with Schistosoma mansoni.}

Schistosoma mansoni worms harvested from hamsters were washed inRPMI 1640 medium (Gibco) supplemented with $200 \mu \mathrm{g} / \mathrm{ml}$ streptomycin, $200 \mathrm{IU} / \mathrm{ml}$ of penicillin (Invitrogen), and $25 \mathrm{mM}$ of Hepes. Adult worm pairs (male and female) were incubated in 24-well culture plate (Techno Plastic Products, TPP) containing $2 \mathrm{~mL}$ of the same medium supplemented with $10 \%$ heat-inactivated calf serum at $37{ }^{\circ} \mathrm{C}$ and at $5 \% \mathrm{CO}_{2}$ atmosphere (Xiao et al., 2007). After 2 hours, epiisopiloturine was added to the culture, yielding a final drug concentration of 50 to $200 \mu \mathrm{g} / \mathrm{mL}$ (Shuhua and Catto, 1989). The control worms were assayed in RPMI 1640 medium with 2\% DMSO as a negative control group and in $10 \mu \mathrm{M}$ PZQ as a positive control group. All experiments were 
carried out in triplicates. Worm motility, tegumental alterations, and the survival of the parasites were monitored on daily basis for 5 days using an inverted microscope and a stereomicroscope (SMZ 1000, Nikon).

\subsubsection{Tegumental changes.}

Quantification of the number of tubercles of helminthes was performed using a confocal microscope. After established times or in the occurrence of death, parasites were fixed in Formalin-Acetic-Alcohol solution (FAA) and analyzed under confocal microscopy (Laser Scanning Microscopy, LSM 510 META, Zeiss) at $488 \mathrm{~nm}$ (exciting) and $505 \mathrm{~nm}$ (emission) as described by Moraes et al. (2009). A minimum of three areas $(20,000 \mu \mathrm{m} 2)$ of the tegument of each parasite was assessed. Numbers of intact tubercles was noted and calculated with the Zeiss LSM Image Browser software.

\subsection{Statistical Analysis}

ANOVA and Kruskal-Wallis tests were used to compare multiple normal or nonnormal samples, respectively. Student's t-test and Mann-Whitney test were used to compare two normal or non-normal samples, respectively. The BioEstat 5.0 software package (Belém, Brazil, 2007) was used for performing the statistical tests and for graphical representations.

\section{Results and Discussion}

The RP-HPLC (High Performance Liquid Chromatography) purification of the alkaloid extract of jaborandi leaves resulted in several fractions, one of them identified by electrospray ion trap mass spectrometry as epiisopiloturin $([\mathrm{M}+\mathrm{H}+]=287.061)$. The 
fragmentation pattern of this molecule confirmed its structure as identical to that described by Voigtlander et al. (1978) using C-RMN (Figure 1).

In vitro assays revealed that epiisopiloturin has significant leishmanicidal activity to the amastigote form of Leishmania amazonensis IFLA/BR/67/PH-8. Epiisopiloturin at a concentration of $128 \mu \mathrm{g} / \mathrm{mL}$ lowered the association index between peritoneal macrophages and L. amazonensis significantly in the control group (Figure 2 A, 2B, 2C, and 2D). However, it did not produce detectable mortality to the promastigote form in the assayed concentrations (data not show).

This is probably due to the morphological and biochemical plasticity of the two forms presented by the parasite, including a differential energy metabolism and transport across membranes (Killick and Rioux, 1991). Most of the drug-screening experiments against Leishmania have been performed on promastigotes and not on the amastigotes, which is the actual parasitic phase that causes the infection in humans and dogs (Baneth and Shaw, 2002; Ordóñez-Gutíerrez et al., 2007). It is not possible at the moment to determine the reason for the epiisopiloturin selectivity, due to its unknown mechanism of action. However, azoles are known to inhibit the growth of Leishmania amastigotes by preventing the cytochrome P-450-mediated 14- $\alpha$-demethylation of lanosterol, blocking ergosterol synthesis and causing accumulation of 14- $\alpha$-methyl sterols (Srinivas et al., 2009). Sterol biosynthesis inhibitors offer an attractive possibility, as Leishmania parasites synthesize specific sterols which seem to be essential for cell proliferation and viability (Chance, 1995).

The cytotoxicity of epiisopiloturin to peritoneal macrophage cells was evaluated. The number and viability of macrophage peritoneal cells adhered to sample wells after incubation with the alkaloid up to a concentration of $128 \mu \mathrm{g} / \mathrm{mL}$ did not differ significantly to the control (Figure 3). This is in agreement with other imidazole 
compounds that did not demonstrate strong toxic actions to mammalian cells (acute toxicity and cytotoxicity) (Kowalska-Pylka et al., 2001). However, some azoles have high toxicity to the kidneys and liver, such as ketoconazole, a typical azole compound binds to mammalian P450 enzymes, including P4503A4 and several steroid hydroxylases (Billaud et al., 2009).

A number of side-effects are associated with ketoconazole as a result of inhibition of these mammalian enzymes (Venkatakrishnan et al., 2000). Ketoconazole leads to liver damage due to its ability to inhibit P4503A4, the major P450 isoform of the liver (CuppVickery et al., 2001).

The effect of epiisopiloturin on adult worms of $S$. mansoni was evaluated alterations in motor activity and in the tegument of the helminthes after incubation with increasing concentrations of the alkaloid, as shown in Table 1 . After $120 \mathrm{~h}$ of incubation, the worms of the negative control groups maintained normal movement with no detectable alterations. As shown in Table 1, all adult worms were dead after 72 and $120 \mathrm{~h}$ of incubations with epiisopiloturin at a concentration of 200 and $150 \mu \mathrm{g} / \mathrm{mL}$, respectively (Table 1). Worms incubated with epiisopiloturin at $150 \mu \mathrm{g} / \mathrm{mL}$ showed decreased motor activity without tegumental alterations worms incubated with epiisopiloturin at $150 \mu / \mathrm{mL}$ showed Decreased motor activity without tegumental alterations in many individuals after 72 of incubation. However, the group 13 treated with $2.0 \%$ DMSO, did not significantly decrease the worm viability in comparison with the positive (PQZ) control group.

Morphological alterations of the tegument on the $S$. mansoni surface were detected at an epiisopiloturin concentration of $200 \mu \mathrm{g} / \mathrm{mL}$. A pattern consisting of a combination of changes in surface morphology were detected and correlated to the death of the worms (Figure 4). For the extraction of quantitative parameters, an area of 
$20,000 \mu \mathrm{m}^{2}$ was demarcated and healthy tubercles were counted (Figure 5). Even at concentrations that induced the parasites death, motility and morphological changes in the surface could be detected.

The analysis by laser scanning confocal microscopy was efficient to detect alterations in the surface of the parasite, in the right column of Figure 4, we can see in detail the changes in tubercles associated with increasing concentrations of the alkaloid. In previous works, similar techniques were used to evaluate effects of drugs.

The mechanism by which epiisopiloturin imidazole alkaloid exerts it's in vitro schistosomicidal effect is not clear, but our results indicate that epiisopiloturin possesses activity against adult worms. Our results indicated that epiisopiloturin against in vitro leishmanicidal and schistosomicidal activities with irrelevant toxicity activity against mammalian cells. Thus, epiisopilotutin is a promising compound that could be used as lead compound for the development of new antiparasitic agents. Further biological in vitro and in vivo studies are required to evaluate its suitability for designing novel antiparasitic agents.

\section{Acknowledgments}

The authors thank EMBRAPA Recursos Genéticos e Biotecnologia, PósGraduação em Ciência Animal (Universidade Federal do Piauí - UFPI), VEGEFLORA Extrações do Nordeste LTDA, Rede Nanobiomed (Nanobiomedicine Network Capes Brasil) and FINEP Campus Regionais 2007 programs for partially funding the project. We are grateful to Alexsander Seixas de Souza, for excellent technical assistance; to Saulo Martins de Sá Mandel for the valuable comments on the manuscript. 


\section{References}

Abreu, I.N., Sawaya, A.C.H.F., Eberlin, M.N., Mazzafera, P., 2005. Production of pilocarpine in callus of jaborandi (Pilocarpus microphyllus Staph.). In vitro cellular \& developmental biology plant 41, 806- 811 .

Barradas, J.S., Errea, M.I., D’Accorso, N.B., Sepúlveda, C.S., Talarico, L.B., Damonte, E.B., 2008. Synthesis and antiviral activity of azoles obtained from carbohydrates. Carbohydrate research 2468-2474.

Baneth, G., Shaw, S.E., 2002. Chemotherapy of canine leishmaniosis. Veterinary parasitology $106,315-24$.

Billaud, E.M. Antoine, C. Berge, M. Abboud, I. Lefeuvre, S. Benammar, M. Glotz, D., 2009. Management of Metabolic Cytochrome P450 3A4 Drug-Drug Interaction between Everolimus and Azole Antifungals in a Renal Transplant Patient. Clinical Drug Investigation 29, 481-486.

Caffrey, C.R., 2007. Chemotherapy of schistosomiasis: present and future. Current opinion in chemical biology 11, 433-439.

Camargo, E.P., 2008. Doenças Tropicais. Estudos avançados 22(64), 95-110.

Chance, M.L., 1995. New developments in the chemotherapy of leishmaniasis. Annals of tropical medicine and parasitology 89, S37-43 
Costa, P.V. Processo de obtenção e purificação de pilocarpina e seus sais. BR Pat. PI9203183, 1999-07-06. p.8.

Cupp-Vickery, J.R., Garcia, C., Hofacre, A., McGee-Estrada, K., 2001. Ketoconazole-induced Conformational Changes in the Active Site of Cytochrome P450. Journal of molecular biology $311,101-110$.

Davies, S.G., Roberts, P.M., Stephenson, P.T., Thomson, J.E., 2009. Syntheses of the racemic jaborandi alkaloids pilocarpine, isopilocarpine and pilosinine. Tetrahedron letters 50, 35093512 .

Doenhoff, M., Cioli, D., Utzinger, J., 2008. Praziquantel: mechanisms of action, resistance and new derivatives for schistosomiasis. Current opinion in infectious diseases 21, 659-667.

Dunning, N., 2009. Leishmania vaccines: from leishmanization to the era of DNA technology. Bioscience horizons 2, 73-82.

Escaron, C.J., Lees, D.M., Tewari, R., Smith, D.F., Caron, E., 2007. A simple, robust and versatile method to characterise intracellular parasitism. Molecular and biochemical parasitology 153, $72-76$.

Hadj-esfandiari, N., Navidpour, L., Shadnia, H., Amini, M., Samadi, N., Faramarzi, M.A. and Shafiee, A., 2007. Synthesis, antibacterial activity, and 16 quantitative structure-activity relationships of new (Z)-2-(nitroimidazolylmethylene)-3(2H)-benzofuranone derivatives. Bioorganic \& medicinal chemistry letters 17, 6354-6363. 
Kayser, O., Kiderlen, A.F., 2001. In vitro leishmanicidial activity of naturally occurring chalcones. Phytotherapy research 15, 148-152.

Kedzierski, L., Sakthianandeswaren, A., Curtis, J.M., Andrews, P.C., Junk, P.C., Kedzierska, K., 2009. Leishmaniasis: Current Treatment and Prospects for New Drugs and Vaccines. Current medicinal chemistry 16, 599-614(16).

Khabnadideh, S., Rezaei, Z., Khalafi-Nezhad, A., Bahrinajafi, R., Mohamadi, R, Farrokhroz, A.A., 2003. Synthesis of N-Alkylated derivatives of imidazole as antibacterial agents. Bioorganic \& medicinal chemistry letters 13, 2863-2865.

Killick-Kendrick R., Rioux J.A. 1991. Intravectorial cycle of Leishmania in sandflies. Annales de parasitologie humaine et comparee 66(Suppl. 1), 71-74.

Kowalska-Pylka, A.H., Mayer-Dziedzic, B., Niewiadomy, A., Matysiak, J., 2001. Evaluation of substituted benzthioanilides toxicity using in vitro tests. ATLA 29, 547-556.

Lima, C.C., Criddle, D.N., Coelho-de-Souza, A.N., Monte, F.J., Jaffar, M., Leal-Cardoso, J.H., 2000. Relaxant and antispasmodic actions of methyleugenol on guinea-pig isolated ileum. Planta medica 66, 408-411.

Mallia, M.B., Subramanian, S., Banerjee, S., Sarma, H.D, Venkatesh, M., 2006. Evaluation of $99 \mathrm{mTc}(\mathrm{CO}) 3$ complex of 2-methyl-5-nitroimidazole as an agent for targeting tumor hypoxia. Bioorganic \& medicinal chemistry 14, 7666-7670. 
Melo, A.L., Barcellos, N.M.S., Demicheli, C., Frezard, F., 2003. Enhanced schistosomicidial efficacy of tartar emetic encapsulated in pegylated liposomes. International journal of pharmaceutics $255,227-230$.

Moraes, J., Silva, M.P.N., Ohlweiler, F.P., Kawano, T., 2009. Schistosoma mansoni and other larval trematodes in Biomphalaria tenagophila (Planorbidae) from Guarulhos, São Paulo State, Brazil. Revista do Instituto de Medicina Tropical de São Paulo 51, 77-82.

Mosmann, T., 1983. Rapid colorimetric assay for cellular growth and survival: application to proliferation and cytotoxicity assays. Journal of immunological methods 65, 55 .

Murray, H.W., Berman, J.D., Davies, C.R., Saravia, N.G,. 2005. Advances in leishmaniasis. The Journal-lancet 366, 1561-77.

Olender D., Żwawiak, J., Lukianchuk, V., Lesyk, R., Kropacz, A., Fojutowski, A., Zaprutko, L., 2009. Synthesis of some N-substituted nitroimidazole derivatives as potential antioxidant and antifungal agents. European journal of medicinal chemistry 44, 645-652.

Ordóñez-Gutíerrez, L., Espada-Fernández, R., Dea-Ayuela, M. A., Torrado, J. J., BolásFernandez, F., Alunda, J. M., 2007. In vitro effect of new formulations of amphotericin B on amastigote and promastigote forms of Leishmania infantum. International journal of antimicrobial agents $30,325-329$.

Rocha, L.G., Almeida, J.R.G.S., Macêdo, R.O., Barbosa-Filho, J.M., 2005. A review of natural products with antileishmanial activity. Phytomedicine 12, 514-535. 
Sawaya, A.C.H.F., Abreu, I.N., Andreazza, N.L., Eberlin, M.N., Mazzafera P., 2008. HPLC-

ESI MS/MS of Imidazole Alkaloids in Pilocarpus microphyllus. Molecules 13, 15181529 .

Shuhua, X., Catto, B.A., 1989. In vitro and in vivo studies of the effect of artemether on Schistosoma mansoni. Antimicrobial agents and chemotherapy 33, 1557-1562.

Smithers, S.R., Terry, R.J., 1965. The infection of laboratory hosts with cercariae of Schistosoma mansoni and the recovery of the adult worms. Parasitology 55, 695-700.

Srinivas, N., Palne, S., Nishi, Gupta, S., Bhandari., 2009. Aryloxy cyclohexyl imidazoles: A novel class of antileishmanial agents. Bioorganic \& medicinal chemistry letters 19, 324-327.

Steinmann, P., Keiser, J., Bos, R., Tanner, M., Utzinger, J., 2006. Schistosomiasis and water resources development: systematic review, meta-analysis, and estimates of people at risk. The Lancet infectious diseases 6, 411-425.

Venkatakrishnan, K., Moltke, L. L., Greenblatt, D. J., 2000. Effects of the antifungal agents on oxidative drug metabolism: clinical relevance. Clinical pharmacokinetics $38(2)$, 111-180.

Voigtlander, H.W., Balsam, G., Engelhardt, M., 1978. Epiisopiloturin, ein Neues PilocapusAlkaloid. Archiv der Pharmazie 311, 927-935. 
Walczak K., Gondela A., Suwiński J., 2004. Synthesis and anti-tuberculosis activity of Naryl-C-nitroazoles. European journal of medicinal chemistry 39, 849-853.

World Health Organization (WHO), 2009 . Neglected Tropical Diseases. Available at: http://www.who.int/neglected_diseases/en (accessed 29.10.2010).

Xiao, S.H., Keiser, J., Chollet, J., Utzinger, J., Dong, Y., Endriss, Y., Vennerstrom, J.L., Tanner, M., 2007. In vitro and in vivo activities of synthetic trioxolanes against major human schistosome species. Antimicrobial agents and chemotherapy 51, 1440-1445. 


\section{Legends to Figures}

Figure 1. (A) ESI+ MS spectra of epiisopiloturin showing the fragmentation from $[\mathrm{M}+\mathrm{H}+]=$ 287.04 parent ion. (B) MS/MS the fragment ion $[\mathrm{M}-\mathrm{H} 2 \mathrm{O}+\mathrm{H}]+=269.04$. (C) MS3 the fragments ions are $[\mathrm{M}-2 \mathrm{H} 2 \mathrm{O}+\mathrm{H}]+=251.08,[\mathrm{M}-\mathrm{H} 2 \mathrm{O}-\mathrm{CH} 2 \mathrm{O} 2+\mathrm{H}]+=223.08$ and $\mathrm{M} / \mathrm{z}=95.04$, this ion most probably corresponds to the positively charged (3-methylimidazole)methylene.

Figure 2. Effect of epiisopiloturin on amastigotes of Leishmania amazonensis. (A) Untreated infected macrophages, added with epiisopiloturin at (B) $2 \mu \mathrm{g} / \mathrm{mL}$, (C) $16 \mu \mathrm{g} / \mathrm{mL}$, and (D) 128 $\mu \mathrm{g} / \mathrm{mL}$. Results are expressed as Association Index (A.I.) $=$ Percentage of infected macrophages x number of parasites per cell.

Figure 3. Effect of epiisopiloturin on macrophage peritoneal cells as measured by MTT assay. Each bar represents standard error of three independent experiments with similar results. The results analyzed by the Kruskal-Wallis test did not show differences between treatments $(\mathrm{p}>0.05)$.

Figure 4. Effect of epiisopilotutin on the tegument of Schistosoma mansoni. After 120 hours of incubation with epiisopiloturin, adult male worms were fixed and fluorescent images were obtained using confocal microscopy. (A) Non-treated with epiisopiloturin (negative control). (C), (E), and (G), morphological structure on the S. mansoni induced by dose-dependent epiisopiloturin concentrations indicated on each inset. (B) Higher magnification of negative control. (D), (F), and (H) showed higher magnification on the $20.000 \mu \mathrm{m}^{2}$ of surface area calculated with the Zeiss LSM Image Browser software.

Figure 5. The quantification of the number of tubercles was performed using confocal microscopy. Indicated are numbers of intact tubercles and these numbers were measured 
in a $20,000 \mu \mathrm{m}^{2}$ of area calculated with the Zeiss LSM Image Browser software. A minimum of three tegument areas of each parasite were assessed. Values are means \pm SD (bars) of six male adult worms. 
Table 1. In vitro effects of epiisopiloturin against 49-day-old adult Schistosoma mansoni

\begin{tabular}{|c|c|c|c|c|c|c|c|}
\hline \multirow{2}{*}{ Group } & \multirow{2}{*}{$\begin{array}{l}\mathrm{N}^{\circ} \text { of worms } \\
\text { investigated }\end{array}$} & \multirow{2}{*}{$\begin{array}{l}\text { Incubation } \\
\text { of period } \\
\text { (h) }\end{array}$} & \multirow{2}{*}{$\begin{array}{c}\mathrm{N}^{\mathrm{o}} \text { of } \\
\text { dead } \\
\text { worms }\end{array}$} & \multicolumn{2}{|c|}{$\begin{array}{l}\text { Motor activity } \\
\text { reduction }\end{array}$} & \multicolumn{2}{|c|}{$\begin{array}{l}\mathrm{N}^{0} \text { of worms with } \\
\text { tegumental alterations }\end{array}$} \\
\hline & & & & Slight & Significant & Partial & Extensive \\
\hline \multirow[t]{5}{*}{ Control $^{\mathrm{a}}$} & 12 & 24 & 0 & 0 & 0 & 0 & 0 \\
\hline & 12 & 48 & 0 & 0 & 0 & 0 & 0 \\
\hline & 12 & 72 & 0 & 0 & 0 & 0 & 0 \\
\hline & 12 & 96 & 0 & 0 & 0 & 0 & 0 \\
\hline & 12 & 120 & 0 & 0 & 0 & 0 & 0 \\
\hline \multirow[t]{5}{*}{$\mathrm{PZQ}^{\mathrm{a}}$} & 12 & 24 & 12 & 0 & 12 & 2 & 10 \\
\hline & 12 & 48 & 12 & 0 & 12 & 2 & 10 \\
\hline & 12 & 72 & 12 & 0 & 12 & 2 & 10 \\
\hline & 12 & 96 & 12 & 0 & 12 & 2 & 10 \\
\hline & 12 & 120 & 12 & 0 & 12 & 2 & 10 \\
\hline Epiisopiloturin & 12 & 24 & 0 & 0 & 0 & 0 & 0 \\
\hline \multirow[t]{4}{*}{$25 \mu \mathrm{g} / \mathrm{mL}$} & 12 & 48 & 0 & 0 & 0 & 0 & 0 \\
\hline & 12 & 72 & 0 & 0 & 0 & 0 & 0 \\
\hline & 12 & 96 & 0 & 0 & 0 & 0 & 0 \\
\hline & 12 & 120 & 0 & 0 & 0 & 0 & 0 \\
\hline Epiisopiloturin & 12 & 24 & 0 & 0 & 0 & 0 & 0 \\
\hline \multirow[t]{4}{*}{$50 \mu \mathrm{g} / \mathrm{mL}$} & 12 & 48 & 0 & 0 & 0 & 0 & 0 \\
\hline & 12 & 72 & 0 & 0 & 0 & 0 & 0 \\
\hline & 12 & 96 & 0 & 0 & 0 & 0 & 0 \\
\hline & 12 & 120 & 0 & 0 & 0 & 0 & 0 \\
\hline Epiisopiloturin & 12 & 24 & 0 & 0 & 0 & 0 & 0 \\
\hline \multirow[t]{4}{*}{$100 \mu \mathrm{g} / \mathrm{mL}$} & 12 & 48 & 0 & 0 & 0 & 0 & 0 \\
\hline & 12 & 72 & 0 & 2 & 0 & 0 & 0 \\
\hline & 12 & 96 & 0 & 4 & 2 & 0 & 0 \\
\hline & 12 & 120 & 0 & 6 & 4 & 0 & 0 \\
\hline Epiisopiloturin & 12 & 24 & 0 & 0 & 0 & 0 & 0 \\
\hline \multirow[t]{4}{*}{$150 \mu \mathrm{g} / \mathrm{mL}$} & 12 & 48 & 0 & 4 & 2 & 0 & 0 \\
\hline & 12 & 72 & 0 & 8 & 4 & 2 & 0 \\
\hline & 12 & 96 & 0 & 2 & 10 & 3 & 1 \\
\hline & 12 & 120 & 12 & 0 & 12 & 0 & 6 \\
\hline Epiisopiloturin & 12 & 24 & 0 & 6 & 0 & 2 & 0 \\
\hline \multirow[t]{4}{*}{$200 \mu \mathrm{g} / \mathrm{mL}$} & 12 & 48 & 0 & 6 & 6 & 3 & 0 \\
\hline & 12 & 72 & 12 & 0 & 12 & 0 & 6 \\
\hline & 12 & 96 & 12 & 0 & 12 & 0 & 6 \\
\hline & 12 & 120 & 12 & 0 & 12 & 0 & 6 \\
\hline
\end{tabular}

${ }^{\mathrm{a}} 2 \%$ DMSO.

${ }^{\mathrm{b}}$ Tested at concentration of $3 \mu \mathrm{g} / \mathrm{mL}$. 
Figure 1

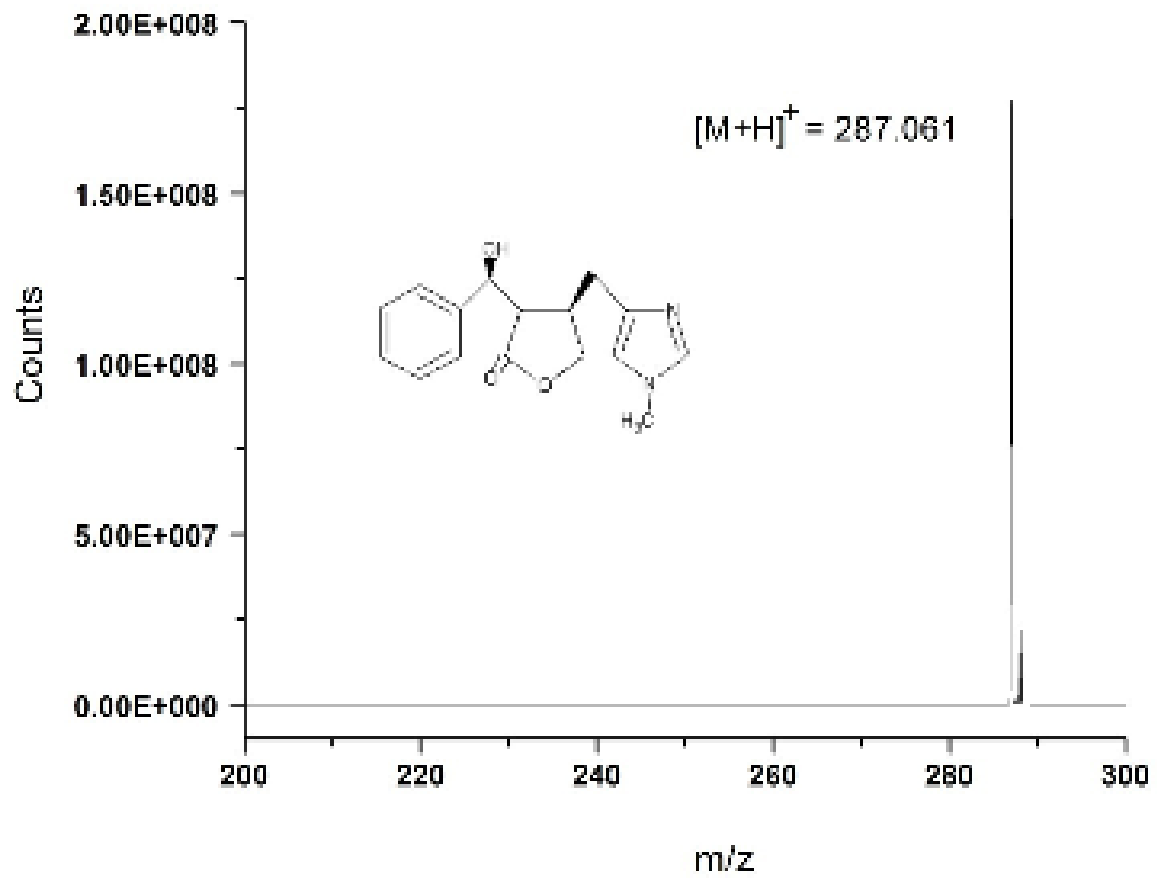


Figure 2.
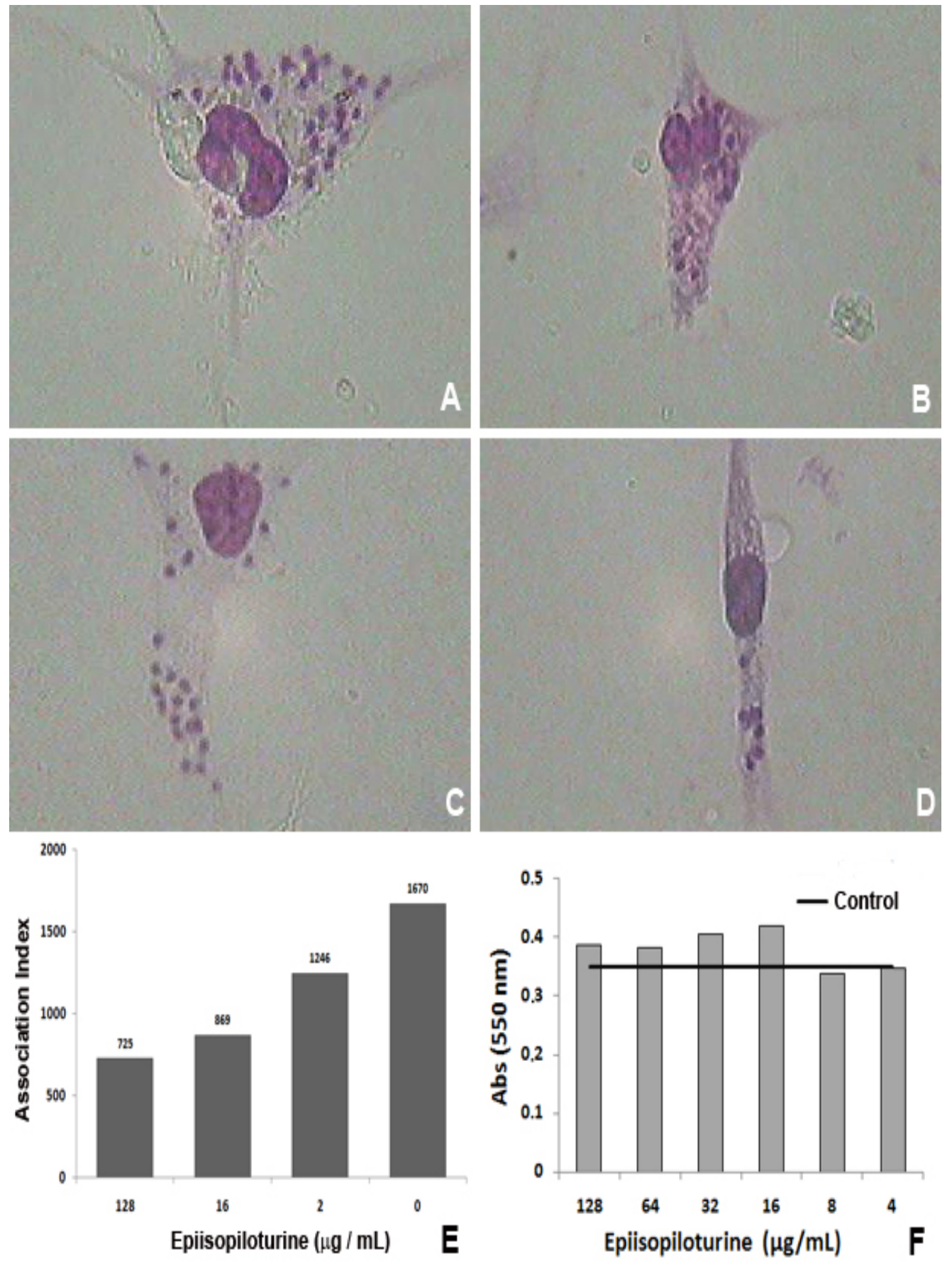
Figure 3.

$0 \mu \mathrm{g} / \mathrm{mL}$

$100 \mu \mathrm{g} / \mathrm{mL}$
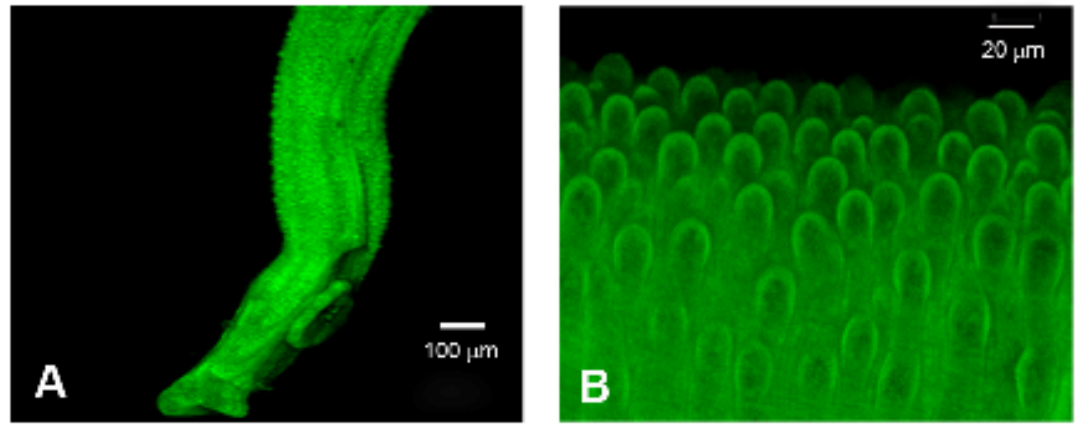

$150 \mu \mathrm{g} / \mathrm{mL}$
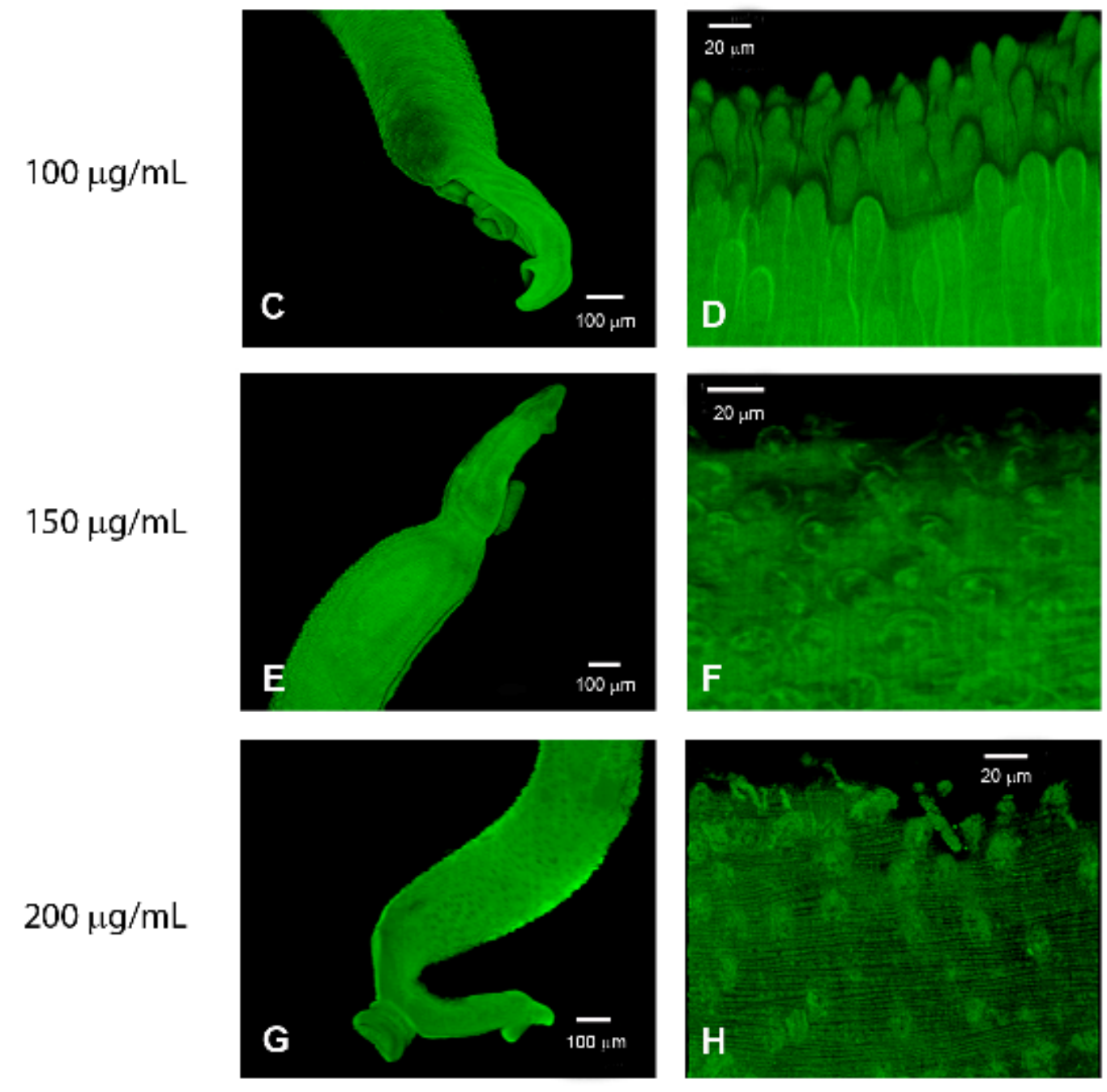
Figure 4.

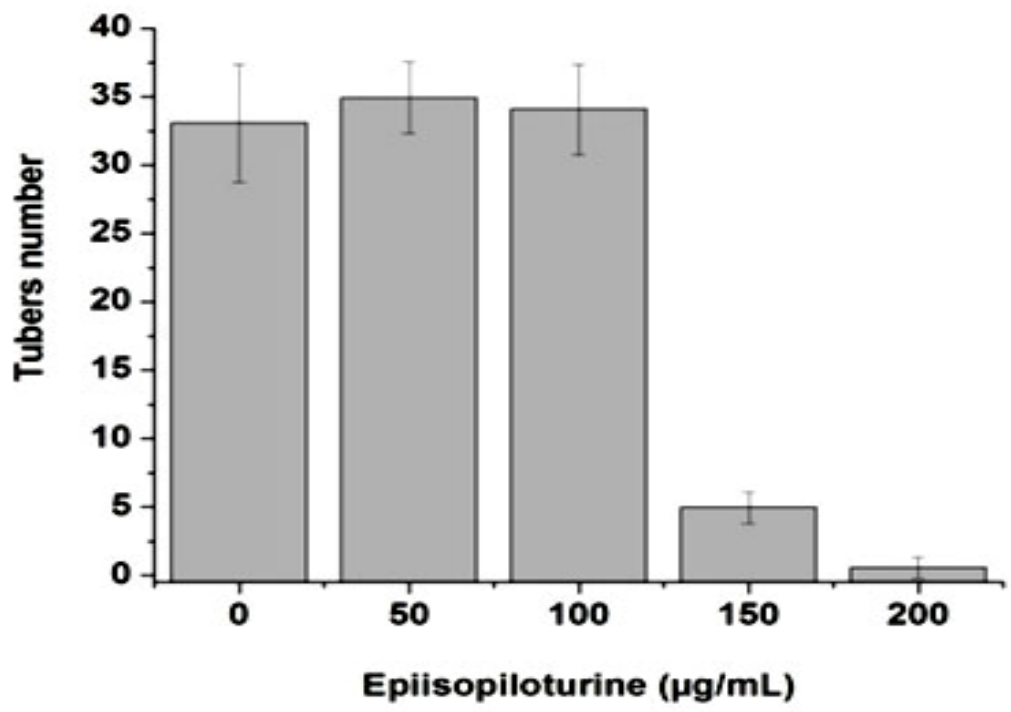

